goves: 





\section{FOOT-NOTES TO EVOLUTION}

"A sacred Kinship I would not forego Binds me to all that breathes." Boyesen 


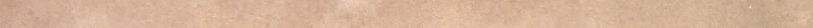

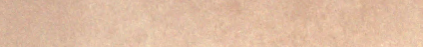

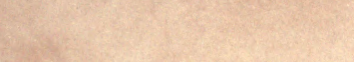

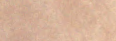

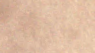

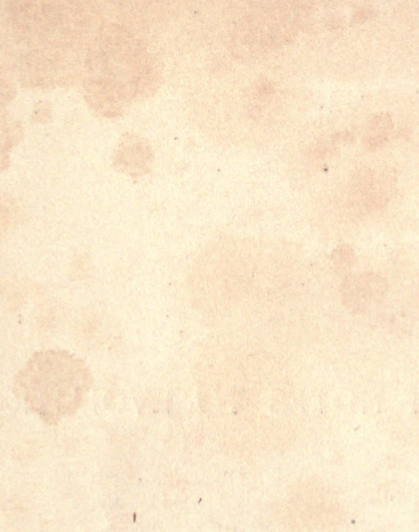





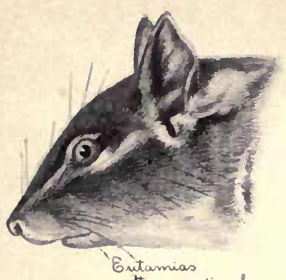

Hownoandi ochrognnys

mendocino Co.

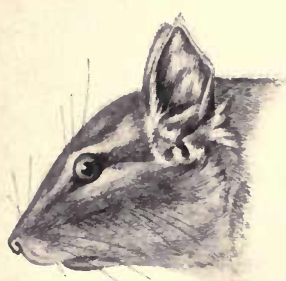

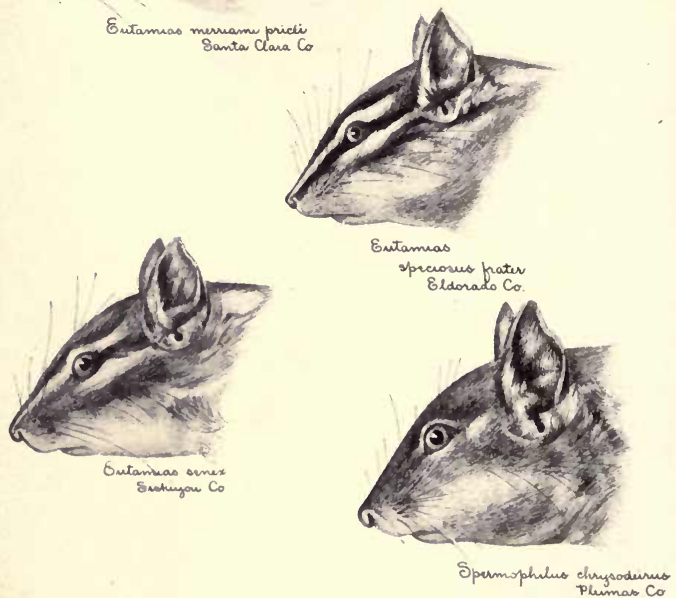

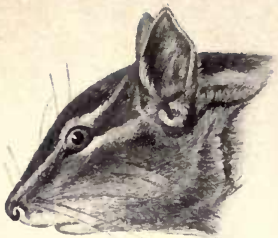

Gutamias hundor marin $C_{0}$.

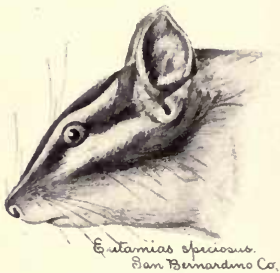

Some chipmunks of California, showing distinct species produced through isolation.

From nature, by William Sacketon Atkinson. 


\title{
FOOT-NOTES TO EVOLUTION A SERIES OF POPULAR ADDRESSES ON THE EVOLUTION OF LIFE
}

\author{
BY \\ DAVID STARR JORDAN, PH. D. \\ PRESIDENT OF LELAND STANFORD JUNIOR UNIVERSITY
}

WITH SUPPLEMENTARY ESSAYS BY

EDWIN GRANT CONKLIN, Ph. D. PROFESSOR OF COMPARATIVE EMBRYOLOGY IN THE UNIVERSITV OF PENNSYLVANIA

. FRANK MACE McFARLAND, Рн. D.

ASSOCIATE PROFESSOR OF HISTOLOGY

IN LELAND STANFORD JUNIOR UNIVERSITY

JAMES PERRIN SMITH, PH. D.

PROFESSOR OF PALEONTOLOGY IN

LELAND STANFORD JUNIOR UNIVERSITY

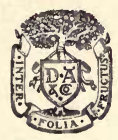

\footnotetext{
NEW YORK

D. APPLETON AND COMPANY

1898
} 
COPYRIGHT, 1898, BY DAVID STARR JORDAN. 


\section{TIMOTHY HOPKINS,}

OF MENLO PARK, CALIFORNIA,

FOUNDER OF THE SEASIDE LABORATORY OF BIOLOGY ON MONTEREY BAY,

IN RECOGNITION OF HIS FRIENDLY AID

TO SCIENTIFIC INVESTIGATION. 



\section{PREFATORY NOTE.}

THE present volume is made up of popular essays or addresses on the general subject of Organic Evolution. These were originally given as oral lectures before University Extension societies in California, having been condensed and written out in their present form after delivery. Three of these papers have already appeared in Appletons' Popular Science Monthly, and three in The Arena. To the editors of these periodicals I am indebted for the privilege of reprinting them.

Besides the twelve essays of my own, it is my good fortune to enhance the value of the volume by the insertion of three papers of special importance, setting forth the present state of knowledge concerning the method of evolution and the method of heredity. The first of these, on the Factors of Organic Evolution as displayed in the Process of Development, is by Professor Edwin Grant Conklin, of the University of Pennsylvania; the second, on the Physical Basis of Heredity, is by Professor Frank Mace McFarland, of Leland Stanford Jr. University; the third, on the Testimony from Paleontology, is by Professor James Perrin Smith, of 
Leland Stanford Jr. University. The essay of Professor Conklin was read before the American Philosophical Society. The others are here presented for the first time.

I may add that the present volume is not intended as a text-book in Evolution, although most phases of organic development are in one way or another touched upon, some of them, however, most briefly. The treatment of different topics is necessarily unequal. The time is long past when any one man can master what is known in any science, least of all the universal science of life. In the supplementary essays I have asked my scientific friends to do for this volume certain work which I could not do except by the unsatisfactory method of compilation.

David StARR JORDAN.

Palo Alto, Callfornia, January $19,1898$. 


\section{ANALYSIS OF CONTENTS.}

I.-The Kinship of Life.

What is the cause of variety in life? What is a species? The number of species. The unity of type. Unity in variety. The meaning of homology. The origin of variety and the origin of homology. The origin of life unknown. The answer of Linnæus. The answer of Cuvier. The answer of Lamarck. The answer of Agassiz. What is special creation? All life from life. Uncertain boundaries of species. The species of fishes of North America. The species of the Galapagos. Do species change with space? The species of South American edentates. Do species change with time? Darwin's answer. Darwin's method. The origin of species. The Darwinian theory. Artificial selection. Natural selection. The struggle for existence. Relation of bees to clover. Relation of cats to England's greatness. The equilibrium of Nature. More organisms born than can mature. How the hare becomes white. How selection becomes adaptation. Acceleration of development. How bisexual parentage brings variety. "Vom Vater hab' ich die Statur." The value of death. The saving of time. Altruism and its struggle for existence. Every fact has a meaning. Geographical distribution. Survival of the existing. Geological distribution. Epoch-making events. Change not progress. Vestigial organs. The pineal eye. Origin of complex structures. The individual repeats the history of the race. Embryology and evolution (John Sterling Kingsley). Similarity of early stages in embryonic life. The egg of the mammal. Embryonic struc- 
tures in man. Gill slits in man. Objections to the theory of descent. Relation of present heredity to past environment. Darwin's hope. The species of eel. The reality of species. The old idea of species has passed away. The acceptance of the theory of descent. The philosophy of evolution. Influence of theory of descent. Origin of man. Meaning of homology. Decaying scientific beliefs. Darwin's words. The conception of God. Darwin's home. Boyesen on evolution.

II.-Evolution: WHAT IT IS AND WHAT IT IS NOT .

What evolution is. The science of organic evolution or bionomics. Meaning of law. Soundness and solvency of Nature. The indifference of Nature. Evolution as a theory of organic development. Each fact has a meaning. Evolution as a method of study. Evolution as a system of cosmic philosophy. Decay of formulæ. What evolution is not. Man not a developed monkey. Not progress, but adaptation. Humanity not the goal of evolution. Change by slow divergence. No innate tendency toward progression. Spontaneous generation. Evolution not a creed. Evolution not a religion. Science its own witness.

III.-The Elements of ORganic Evolution .

Heredity. Irritability. Individuality. Natural selection. Concessions of life. Self-activity. Altruism. Isolation. Nutrition in transmission. Survival of the existing. Inheritance of acquired characters. The unknown factors.

IV.-The Factors of Evolution From the Standpoint of Embryology. By Professor Edwin Grant Conklin 100

Embryology shows the method of evolution. Statement of propositions. Causes of development. Intrinsic causes dependent on nature of protoplasm. Inherited characters predetermined in structure of germ cell. Germinal 
protoplasm relatively but not absolutely stable. Do extrinsic factors affect germinal protoplasm ? Diminished nutrition. . Changes in environment. Use and disuse. Mechanical conditions. Results of impact. Value of direct experiment. Return to the position of Darwin. The final word still far distant.

\section{V.-THE HEREDITY OF RICHARD ROE}

Formation of character. Hereditary tendencies. Inheritance of humanity. Inheritance of race characters. Individual characters. The germ cell. Protoplasm. Chromatin. Inequality of Nature's divisions. Atavism. The mid-parent. The thoroughbred. Changes through experience. Inheritance of acquired characters. Nature of acquired characters. Prenatal influences. Transmission of impaired vitality. Ibsen's ghosts. Potentialities not character. The higher heredity. The unity of the ego. The ego a co-operation. Fame not greatness. Counting one's ancestors. Lineage of a little girl. All Englishmen of noble birth. Effect of primogeniture. Origin of the English character. Race types and the survival of the existing.

VI.-The Physical Basis of Heredity. By Professor Frank Mace McFarland

The cell theory. The meaning of the term "cell." Unicellular and multicellular organisms. The essential parts of the cell. The protoplasm. The nucleus. Karyokinesis. The chromosomes. Division of the centrosome. The spindle. Division of the chromosomes. Phases of cell division by karyokinesis. Direct division. Somatic and reproductive tissues. Differentiation of somatic and reproductive tissues in Ascaris. Reproduction in Protozoa. Conjugation. Gradual differentiation of reproductive cells. Reproduction in Eudorina. Reproduction in Metazoa. Fundamental identity of the germ cells. The egg cell. Maturation. The sperm cell. Fertilization. Cleavage. The reduction of the chromosomes. Theories as to structure and significance of the 
chromosome. The ultimate vital units. Significance of reduction. Reduction in Ascaris. Reduction in Crustacea. The chromatin as the bearer of hereditary influence. Indirect evidence. Direct experimental evidence.

\section{VII.-The Distribution of Species}

Illustrations not arguments. Cumulative evidence. The fauna of the Galapagos. Island life. Effects of migration on species. Effects of isolation. Barriers to diffusion. Holarctic realm. Neotropical realm. Ethiopian realm. Indian realm. Australian realm. Anomalies in distribution. Adaptation of animals to environment. Invasion of the Australian realm. Trout in Yellowstone Park. Two-Ocean Pass. Laws of distribution of animals. Barriers of land, sea, and climate. Interdependence of species. The arctic birch. Crossing the barriers. The flying fish. Subspecies or geographical variations. Doubtful species. Darwin's experience. The shore larks. Work of Dr. J. A. Allen. Species defined by missing links. Analogy between variations of species and of words. A fauna like a language. The survival of the existing. How species change with time. Physiological isolation.

\section{VIII.-LATITUdE AND VERTEBRA .}

Northern fishes have most vertebræ. Fewest vertebræ in shore fishes of the tropics. Fewer vertebræ indicates greater specialization. Analogy of tropical waters to cities of men. Origin of eels. Coral reefs the centre of fish competition. Cephalization through competition.

iX.-Evolution of Fossil Cephalopoda. By Professor James Perrin Smith

Introduction: General evidence of paleontology ; incompleteness of the record. Law of acceleration of development. Nomenclature of stages of growth. Paleontogeny: General statement; Brachiopoda; Crustacea ; Mollusca; Pelecypoda; Cephalopoda; Method of work- 
ing. Development of Glyphioceras. Development of Schlonbachia.

Mind the sum total of psychic changes. Mind not consciousness. Function precedes structure. Irritability the basis of mind. The brain adequate for the mind. The marvel of life. Activities of Protozoa. Sensation related to action. Mind of the plant. Locomotion demands sensation. Reflex action. The higher heredity. Realities and"illusions. Selections of sensations. Robust men make history. Relation of the child to the environment. The sensorium. Nature of instinct. Instinct of the fur seal. Nature of the intellect. Effect of adversity on the intellect. Intellect of the monkey people. Intellect the choice of responses. Intellect of the fur seal. The "Clavier" theory of mind. Colonial consciousness. "Cogito, ergo sum." Development of the ego. The building of the self. Sensation without action. Impulse and action. Degeneration. Power of attention. Defects in mental operation. Phenomena of hysteria. Effect of drugs. The mind of nations.

Decline in range of activities. Quiescent animals. Tunicates. Parasitic animals. Sacculina. Animal pauperism homologous with human pauperism. Law of compensation. Degeneration of senility. Race degeneration. Lineage of degeneracy short. Withered branches. Degeneration through charity. The cretins of Aosta. Degeneration in isolation. The Jukes. The poor whites. Degeneration in slavery. Degeneration in the slums. Degeneration in the tropics. Degeneration in luxury. Mental dyspepsia. The higher foolishness. Nordau on degeneration. The mattoid. The normal man. Disease of the nerves not genius. Decadence for mercantile purposes. Causes of decadence. The despondency of Europe. The wholesome world. Degeneration under institutions. Mental pauperism. Spiritual pauperism. 
The art of living. Mutual help preserves the incapable. The easy world. Poverty not pauperism. Degeneration of the inactive. The tribe of Ishmael. Paupers as parasites. Pauperism a factor in government. Corruption fund of public charity. Foreign immigration. Taking away the "freedom which is thraldom to sin."

XIII.-The Woman of Evolution and the Woman of Pessimism

Primary meaning of sex. Primal equality of sexes. Specialization of germ cells. Specialization of the embryo. Maternity and companionship. Woman not undeveloped man. The altruism of parenthood. The philosophy of pessimism. The philosophy of evolution. Schopenhauer's essay on woman. Woman a modified man. Inefficiency of woman. Beauty of young girls. Beauty as a weapon. Triviality of women. Early maturity of woman. Kinđuness of woman. Deceit of woman. Woman lives for the species. Trade jealousy among women. The unæsthetic sex. No mastery of art. Philistinism of woman. The sexes unequal. Woman in European society. The lady-nuisance. The laws of marriage. Dependence of woman. The lordnuisance. Blindness of pessimism. Woman from man's standpoint. Unnatural competition. Evolution of the home. Freedom of man. For each defect a historic cause. Force breeds deceit. The equal marriage. Being a woman. Release from work not idleness.

\section{XIV.-The Stability of Truth . . . . . 33 \\ Assaults on the integrity of science. The secret of} power. Human experience the basis of knowledge. Knowledge and belief. Views of the Marquis of Salisbury. Views of Arthur J. Balfour. Human experience not objective. Ineffectiveness of reason. The nature of self. The terms of human experience. The measure of a man. Nature of sanity. The infinite understanding. The test of truth. The matter philosophy deals with. 
Protyl. Religion and belief. Haeckel's Confession of Faith. Monism. Unity of organic and inorganic Nature. Unity of chemical elements. Monism not science. Spontaneous generation not science. Reincarnation. Haeckel's definition of belief. The inheritance of acquired characters. The courage of patience. Revision of science by philosophy. Science stops where facts stop. Primal motive of science. Message of science. Philosophic doubt and common sense. Each organism a link in the chain of life. Life deals in realities. Conventionality. Authority. Instinct springs from past conditions. Intellect points forward. Practicality of sensations. The sober mind. The recrudescence of superstition. Life based on dreams and illusions. Sensation truthful in the degree that action is possible. Hyperæsthesia of science. Trust in reality makes life safe. Meaning of pain. Value of ideals. The course of life. The world as it is. Subordination of impulses. The search for truth.

XV.-The StRuggle For Realities

The price of truth. The mystic sanction. The struggle against tradition. The struggle against learning. The struggle in the human mind. Nature of the mind. Practicality of the senses. Suggestion and conventionality. The forces outside ourselves. Fear and worship of the unseen powers. The science of our childhood. The world as it is. The conflict between science and religion. The struggle between science and dogmatic theology. The essence of conservatism. The effort to limit thought. The effort to control action. The passing of institutions.

INDEX 



\section{LIST OF ILLUSTRATIONS.}

FIG.

I. Pineal eye of lizard (Hatteria) (after Spencer) . . . 34

2. Pineal eye of lizard, in section (after Spencer) . . 34

3. Head of horned toad (Phrynosama) (after nature, by W. S. Atkinson) . . . . . . . . 35

4. Conjugation of Infusoria (after Leuckart) . . . . 92

5. Karyokinesis of cell (after Drüner) . . . . . 155

6. Reduction of chromatin in egg-cleavage (after Boveri) . I60

7. Development of Pandorina (after Pringsheim) . . 165

8. Colony of Eudorina with antherozooids (after Goebel) . 167

9. Diagram of development of spermatozoa (after Boveri) . $\quad \mathbf{I 7 2}^{2}$

I0. Fertilization of egg (after Boveri) . . . . . 174

Ir. Reduction of chromosomes in developing egg (after Brauer). . . . . . . . . 180

i2. Maturation of egg of Cyclops (after Rückert) . . . $\quad$ I82

13. Larva of Echinus (after Boveri) . . . . . 187

14. Hybrid larva of Echinus and Spharechinus (after Boveri) 189

15. The arctic birch (after nature, by Anne L. Brown). $\quad 209$

16. Skeleton of greenling (Hexagrammos) (after nature, by W. S. Atkinson) . . . . . . . . 224

I7. Skeleton of scarlet rock-fish (Sebastodes) (after nature, by

W. S. Atkinson) . . . . . . . . 224

18. Skeleton of angel fish (Angelichthys) (after nature, by W. S. Atkinson) . . . . . . . . . 225

19. Sacculina after leaving the egg (after Lang) . . $\quad 279$

20. Sacculina attaching itself (after Lang) . . . . 280

21. Sacculina, an early stage (after Lang) . . . . 280

22. Sacculina after absorption of limbs (after Lang) . . 280

23. Adult Sacculina attached to crab (after Lang). . . 28 I 


\section{Xviii FOOT-NOTES TO EVOLUTION.}

FIG.

24. Section of mature Sacculina (after Lang). . . 281

25. Sacculina attached (after Lang) . . . . $\quad 282$

26. Sacculina with limbs absorbed (after Lang) . . . 282

27. Cretin of Aosta (after a photograph by Dr. J. W. Jenks) 285

28. Cretin of Aosta (after Edward Whymper) . . 286

PLATE

FULL-PAGE PLATES.

FACING

PAGE

Some chipmunks of California, showing distinct species produced through isolation (after nature, by William Sacketon Atkinson) . . Frontispiece

I.-Cephalopoda; development of Glyphioceras (after nature, by Mrs. Frances Rand Smith). . . . 240

II.-Development of Glyphioceras (after nature, by Frances Rand Smith) . . . . . . . 242

III.-Development of Schloenbachia (after nature, by Frances Rand Smith) . . . . . . . 246

IV.-Development of septa in Ammonites (after nature, by Frances Rand Smith) . . . . . . 248

V.-Forms of Ammonites (after nature, by Frances Rand Smith) 


\section{FOOT-NOTES TO EVOLUTION.}

I.

THE KINSHIP OF LIFE.

No one with good eyes and brains behind them has ever looked forth on the varied life of the world, on

What is the cause of variety in life?

forest or meadow or brook or sea, without at least once asking himself the question, "What is the cause of Nature's endless variety?" We see many kinds of birds and trees and insects and fishes and flowers and blades of grass, and yet when we look closely we find not one blade of grass in the meadow quite like another blade. The green cloak which covers the brown earth is the shield under which millions of organisms, brown or green, carry on their life work; yet not one organism in the world in body or mind is the exact measure of its neighbour. But with all this the real variety in life is far greater than that which appears.

Each kind of animal or plant, that is, each set of forms which in the vicissitudes of the ages has become What is a segregated and set off from its neighspecies?

bours, is called in biology a species. The number of these species is great beyond any ordinary conception. I have an old book in my library, the tenth edition of the Systema Naturæ, 
published by Linnæus in $\mathbf{1 7 5}$. This book treats of all the species of animals known a century and a half ago. The number of In its eight hundred and twenty-three species.

pages some four thousand different kinds of animals are named and described. But for every one of these enumerated by Linnæus, more than two hundred kinds are known to the modern naturalist, and the number of species still unknown doubtless exceeds that of those already recorded. Every year since 1864 there has been published in London a plump octavo volume known as the Zoölogical Record. Each of these volumes, larger than the whole Systema Naturæ, contains the names of animals new to science added to our list during the year of which it treats. And in the record of each year we find the names of about three times as many animals as are mentioned in the Systema Naturæ. Yet the field shows no signs of exhaustion. As these volumes stand on the shelf together it is easy to see that the later volumes are the thickest, and that the record for the present year is the largest of all. Moreover, what is true of the increase of knowledge in systematic zoölogy is even more marked in the case of botany. Such, then, is the variety of life on the globe -a variety of which Linnæus and his successors had never dared to dream.

And yet, great as this variety is, there are, after all, only a few types of structure among all animals and

The unity of type. plants, some three or four or eight or ten general modes of development, and all the rest are modifications from these few types. It is, moreover, true that all living forms are but series of modifications and extensions of one single plan of structure. All have the same framework of cells, and in each cell we find the same ultimate substance-the mysterious semi-fluid network of proto- 
plasm, which is, so far as we know, the physical basis of all life; and the equally mysterious nuclear substance or chromatin which in some fashion presides over all the movements of the protoplasm and is the physical basis of the phenomena of heredity. The same laws of heredity, variability, and of response to outside stimulus hold in all parts of the organic world. All organisms have the same need of reproduction. All are forced to make concession after concession to their surroundings, and in these concessions all progress in life consists. And at last each organism or each alliance of organisms must come to the greatest concession of all, which we call death.

The unity in life is then not less a fact than is life's great diversity. Whatever the emphasis we may lay Unity in variety. upon the diversity of life, the essential unity of all organisms must not be forgotten. This fundamental likeness among widely varied forms stands as the basis of all classification. It is this only which makes classification possible or conceivable. These bonds of union, which are real as distinguished from resemblances which are merely superficial or apparent, are known to the naturalist as homology. The existence of homologies is the fundamental fact in biological science. It has been regarded as a mystery of mysteries, but this mystery assumes the form of natural law in the light of the plain fact that identity of structure is the simple result of identity of parentage. Homology in any form is simply the stamp of heredity. In other words, homology means blood-relationship. The simplest explanation is the truest and would long ago have been recognized had it not been for prejudices of various sorts-theological prejudices that saw the image of God in man only, and scientific prejudices which arose from the surface study of surfaces. For it is the 
inside of an animal which tells the real history of its ancestry; its outside tells us only where its ancestors have been.

It is perfectly certain that homology represents some real law of Nature, something other than the results of mere chance. When I compare my arm The meaning of homology. with that of my neighbour, I find differences in size and proportions. But these are superficial, and there is the underlying correspondence of each bone and muscle, each nerve fibre, artery, and vein. When I compare my arm with the fore leg of a $\operatorname{dog} I$ find more striking differences, for the dog's station in life is quite unlike my own, and he uses his arm for different purposes. When I compare my arm with the wing of a bird or the pectoral fin of a fish, the results are still similar. Though the differences in each succeeding case become more and more striking, and the resemblance less easy to trace, yet the same resemblances exist, and a closer study shows that these resemblances far outweigh the differences.

We say, then, that homology is real, and whatever power or cause has acted on fishes to provide them with pectoral fins has given to birds wings, to the dog fore legs, and to me and my neighbour arms. The arms are appendages more specialized-that is, more highly finished and suited to more purposes than the others-but all are formed of the same pieces, arranged in the same way. When I compare my arm, however, with the claw of a lobster, the limb of a tree, or the arm of a starfish, all resemblances in gross structure disappear, and we have only the analogies connected with similarity of function. The ultimate homology of cell for cell, however, remains even here with all that this may signify.

Now the problem before us is this: What is the 
origin of variety in life, and how does it come that this variety is based on essential unity? Or, in other words, what is the origin of species, and what The origin of va- is the origin of homology? Obviously, riety and the origin of homology. neither of these questions can be answered without considering the other, and obviously both presuppose the existence of life.

As to the origin of life, we have as yet no basis for speculation. We can only say as a matter of fact that The origin of life life exists on the earth, which was once unknown.

lifeless. How the first organism came to be we can not even guess. By what clashing of elements the vital spark came forth, and whether like causes can or do still produce like effects, no one can say. The spontaneous generation of organisms has never been seen, nor with our dull senses and clumsy instruments could it ever be seen; for an organism without a history, untouched by heredity, unselected by struggle, unaffected by environment, a coin fresh from the mint of creation, would be a fragment of pristine simplicity as far beyond our grasp as the molecules of the chemist. It is likely that it is indeed a molecule, and a molecule in size compares with a drop of water much as an orange compares with the sun. If spontaneous generation exists, such creatures as bacilli and infusoria, small though they are, are not the products of it; for these little creatures have their life history, their habits, and their heredity as firmly fixed as those of the dog or the oak. A life history presupposes a long ancestry, and it is absurd to expect such battlescarred organisms as the least we know to spring full developed from the combination of any of the component atoms.

The origin of life is as yet beyond the reach of speculation. We can not even bring it under investigation, 
for we know too little of it to ask of Nature even an intelligent question which shall bear upon it. But science does not shrink from unanswered problems. Whatever exists may some time be found out, and some day the law of creation may become as much a part of our biological knowledge as the law of heredity bids fair soon to become.

Having stated our problem of the origin of species, let us see what answers have been made to it by some of the great minds of the past. The past in biology is not far distant, for it is barely a century since biological problems were first treated as living questions. A century ago, as I have already said, comparatively few species, either of animals or plants, were known to the naturalist, as but few are now known to those who are not engaged in Nature study. Most of these were not known well. The question as to their origin could not be asked, for the very idea of origins was an unfamiliar one. The fact of the enormous succession of ages that makes up geological time, the thought that "time is as long as space is wide," had scarcely entered the minds even of the boldest thinkers of that day.

In this condition of knowledge the answer to our question was easy. Linnæus said a century and a half

The answer of Linnæus.

ago: "There are as many different species now as there were different forms created in the beginning by the Infinite Being." But Linnæus, with his few boxes of dried plants and his little cabinet of stuffed birds and dried fish skins, had scant conception of the range of variety in Nature, while of the underlying unity he had only occasional glimpses. That the animals and plants in his catalogue were the last in a long succession of life in which species after species had appeared and dropped out, dying or undergoing such changes as to seem to us 
like new creations, was wholly unknown to him. And surely these considerations, these discoveries of a century of scientific activity, can not be ignored in forming our answer to the question of the origin of species.

Some half a century after Linnæus, another naturalist, still greater than he, gave himself to the study of

The answer of Cuvier. homologies, and formed a classification of all animals on the basis of the resemblances seen in their plans of organization. It was known to him that there had been many changes in the history of life, and that the forms now living are but a tithe of the total number of those which have existed.

So the answer of Cuvier was substantially this: There have been many creations and destructions of life in the history of the earth. So far as we can see, it appears that there are as many species now as there were different forms created by the Infinite Being at the beginning of the present geological era.

But it was not easy to show just when the present era began, and the reasons for believing in the repeated total extinctions and creations became less and less strong the more closely the evidence was examined. Nor was it clear why the new creations should be as it were merely modified duplicates of the creatures which had preceded them. Why should the Creator, for instance, in covering the earth with a new creation, carry it right on in the same lines as the old one? Why should he give us not merely birds, reptiles, insects, shells, and ferns as before, but birds, reptiles, insects, shelis, and ferns only to be distinguished from their predecessors by the most careful study of men who have given their lives to such discriminations?

And then there were some men in Cuvier's time who were not satisfied with the answer of Cuvier. Such men 
were Lamarck and Saint-Hilaire, and with them was he who has been called "the sanest of men"-Gœthe. The answer of There had been, they thought, in reality Lamarck.

no new era and no new creation-only a gradual change from old to new, from old life under old conditions to new life with new environment. The natural tendency toward progress in life, the influence of the creatures' own desires and needs, the attempt of creatures to fit themselves to new surroundings were, they thought, in some way the causes of the changes in forms which Cuvier ascribed to new creations.

But there were some facts not easy to explain on these suppositions, and the causes of change suggested by Lamarck seemed to most thinkers of his time entirely disproportionate to the changes themselves. Again, the weight of the great names of Linnæus and Cuvier rested on the other side, and authority has its weight in science as elsewhere when we come to estimate the relative probability of different conclusions. Besides, not enough of fact was in anybody's possession to take these discussions out of the region of speculation. There is reason to believe that Cuvier himself doubted his own dictum as to the special creation, unchanging permanence, and ultimate extinction of species. But Cuvier saw no way to any better view, and he believed that the advancement of science would come through the gathering and sorting of facts rather than from any hypotheses, however ingenious, as to the origin of present conditions.

But the permanence and persistence of type which Cuvier had demonstrated came to be a necessary eleThe answer of Agassiz. ment in the answer to the still vexed question of the origin of species. And this fact of unity formed the cornerstone in the answer given by Agassiz. The species rep- 
resent the divine thoughts embodied in the act of creation. The unity exists in the mind of the Creator. He made them all, and so all bear the stamp of his workmanship. He is infinite, and so they exist in infinite variety. That "material form is the cover of spirit" was to Agassiz "a truth at once fundamental and self-evident." Each species is, then, the material form which clothes a divine idea. Homologies arise not from diverging lines of descent, but from the associations of divine ideas. They are the stamp of uniformity which must accompany all works of a single mind, even though that mind be infinite. To trace this out in Nature is for us to think again the thoughts of God.

This was Agassiz's answer, and it has the charm of poetry, besides breathing the spirit of deep reverence which characterized this great naturalist, to whom the laboratory was not less holy than the church, and "a physical fact not less sacred than a moral principle."

It is a beautiful conception, but one which can not be exactly measured or verified. All science at the bottom is quantitative, and whatever is true to us can be reduced to measurement. We may, moreover, say if we choose that the "thought of God " is not " the unchanging species," but the law under which species are modified and changed. Nature is made up of changing beings produced and acted upon by unchanging laws. It is the mighty unseen force itself rather than the visible and transitory object of its action which, in the language of poetry, we may call the "thought of God."

The progress of knowledge comes not from the growth of beautiful conceptions, but from the subjection of all conceptions and theories to the crucial test of fact. A thought which can not be put to the test of human experience forms no part of science. 
And so, without affirming or denying these views of Agassiz, scientific men have not been satisfied to rest with them.

Admitting that each species has been created, the question of method is still pertinent. What is creation?

What is special How is it performed? What do we creation?

mean, for example, by "special creation " in opposition to the production of species through variations due to natural causes? What knowledge have we of the origin of species as distinguished from the birth point of one of the individuals of this species? If each of the million species of animals and plants which now live, and each of the millions of kinds which have become extinct, has been the object of a "special creation," then "special creation" is but a name to cover our ignorance of the law by which species are produced. What has been done so many times must be done in some uniform way. All our experience in the universe tells us that everything is done in its way and in no other. We no longer picture the Creator as forming dogs and horses and men out of clay and then breathing into them the breath of life. We no longer, with Milton, "imagine" the new created lion as pawing the earth "to free his hinder parts." That is not the way we find lions made. The lion develops from the unborn lion kitten, and this unborn kitten, through heredity typifies its cat-like ancestors. They were cat-like before they became lion-like.

"All life comes from life," is a maxim of the early naturalists. We understand in some measure the method All life from life. of birth, the method by which individuals are created. Why should we think that the creation of species, special series of individuals, has come about in any way other than this, when we know of no other? 
Then again, if species be the subject of special intervention such as some have imagined, how is it that

Uncertain boundaries of species. after years of study we are still uncertain as to their characters and boundaries? We have found that no two individuals of any species are ever quite alike. We know that these variations group themselves together so as to form subordinate races or varietiesspecies within species. We know that again and again these minor forms or subspecies have been mistaken for real species. We know that in thousands of cases today the good and the true species of one writer will be only varieties with another. We know that every year intermediate forms are found which break down the walls between species, so that the better any group is known the smaller becomes its list of species and the greater the range of variations. There is absolutely no test by which we can separate species from races or varieties. Our actual test is the test of ignorance. When we do not know any intervening forms we regard two given species as distinct. When we find intergradations we unite these species. All naturalists have been forced to admit that species seem to be but varieties "of a larger growth," while varieties seem to be incipient species. These facts had been noticed and had been admitted long before most naturalists were willing to believe that such appearances were anything but most deceitful. Professor Cope tells us of a conchologist who kept his species of shells from varying by crushing under his heel all specimens which in any way tended to depart from the proper type. It is only by such methods as this that different species can be kept distinct from each other.

Let us take an illustration out of many that come to hand. Continued explorations bring to light from year 
to year new species of fishes in North American rivers; but the number of new forms now discovered each year is

The species of fishes of North America. usually less than the number of old species which are yearly proved intenable. Four complete lists of the fresh-water fishes of the United States have been published by the present writer and his associates. That of 1876 enumerated 670 species; that of 1878 contained $66_{5}$; the third, in 1885 , only $5^{87}$ species, although upward of 75 new species were detected in the nine years which elapsed between the first and the third list. The list of 1896 , with 50 more additions, contains 599 species. Additional specimens from intervening localities are found to form connecting links among the nominal species, and thus several supposed species become in time merged in one, while not unfrequently the supposed minor variations are the marks of what we must finally regard as real species. Their reality consists simply in the extinction of the intervening forms.

We have briefly reviewed the condition of this problem and its answers before 1836 , when Charles Darwin The species of the Galapagos. returned to England after the voyage of the Beagle. While in South America he had been greatly impressed by two phases of the question which came to his notice during his explorations there. The first of these was the fauna of the Galapagos Islands, a rocky cluster lying well out to sea some five hundred miles off the coast of Peru and Ecuador. The sea birds of these islands are essentially the same as those of the shores of Peru. So with most of the fishes. We can see how this might well be, for both sea birds and fishes can readily pass from the one region to the other. But the land birds, as well as the reptiles, insects, and plants, are mostly peculiar to the islands. The same species are found nowhere else; but 
other species, very much like them in all respects, are found, and these live along the coast of Peru. In the Galapagos Islands, according to Darwin's notes, "there are twenty-six land birds. Of these, twenty-one, or perhaps twenty-three, are ranked as distinct species and would commonly have been assumed to have been here created, yet the close affinity of most of these birds to American species is manifest in every character, in their habits, gestures, and tones of voice. So it is with the other animals and with a large proportion of the plants. ... The naturalist, looking at the inhabitants of these volcanic islands in the Pacific, feels that he is standing on American land."

The question, then, is this: If these species have been created as we find them on the Galapagos Islands, why is it that they should all be very similar in type to other animals living under wholly different conditions but on a coast not so very far away? And, again, why are the animals and plants of another cluster of volcanic islands-the Cape Verde Islands-similarly related to those of the neighbouring coast of Africa and wholly unlike those of the Galapagos? If the animals were created to match their conditions of life, then those of the Galapagos should be like those of Cape Verde, the two archipelagos being extremely alike in respect to soil, climate, and physical surroundings. If the species on the islands are products of separate acts of creation, what is there in the nearness of the coasts of Africa or Peru to influence the act of creation so as to cause the island species to be, as it were, echoes of those on shore?

If, on the other hand, we should adopt the obvious conclusion that both of these clusters of islands have been at one time or another colonized by emigrants from the mainland, by the waifs of wind and storm, the fact of 
uniformity of type is accounted for. But what of the difference of species? If change of conditions may on the islands cause great and permanent changes in a spe-

Do species change with space? cies so as to transform it into a different species, may not the same change take place elsewhere? May it not happen on the mainland as well as on the islands? And if on the mainland, what guarantee have we of the permanence of species anywhere? May they not be constantly changing? May not what we consider as a distinct species be only the present phase in the changing history of the series of forms which constitutes the species?

The other phase of the problem which was presented to Darwin was that of the succession of fossil and recent mammalia, especially the edentates

The species of South American edentates. (ant-eaters, armadillos), etc., in South America. We find in the extinct species the same peculiarities of structure that we see in the forms still living. These peculiarities are not shown by animals either recent or fossil in other parts of the globe. If each of these species has been an independent creation, by what law should the recent forms duplicate the peculiarities of the extinct forms? Is the process of creation in some way influenced by the peculiarities of forms which have preceded these in the same region and not by forms which live in other regions? The explanation is not to be found in the adjustment of species to their conditions of life, for under similar conditions in other regions, as

Do species change with time? in Australia, are found forms wholly different. But as edentate has succeeded edentate in South America, so marsupial has succeeded marsupial in Australia. Is the explanation in both cases to be found in the supposition that the recent forms in both of these 
continents are modified descendants of extinct forms? But if this be so, what certainty have we that other creatures have not been similarly modified? And may they not be still undergoing modification? Then why may not the origin of species be due to descent with modifications? The difference in species would then be the result of the influences which make for change, and the unity would be due simply to the action of the law of the heredity.

And this is the theory which Darwin finally reached. The unity would be accounted for easily enough, for by this view homology is the simple index of common heredity. The fact of variation could be shown, but what could be the cause of variations so universal and on such a grand scale as we find them in Nature? If this law could be worked out, then the innumerable facts of homology and variation would have a meaning instead of being as before so many isolated curiosities of Nature. To the working out of this law he gave twenty-five years of his life, gathering information from every source accessible to man.

To the famous botanist, Joseph D. Hooker, Darwin wrote in 1844 : "Besides a general interest about the Darwin's answer. southern lands, I have been now ever since my return engaged in a very presumptuous work, and I know no one individual who would not say a very foolish one. I was so struck with the distribution of the Galapagos organisms and with the character of the American fossil mammifers that I determined to collect blindly every sort of fact which could bear in any way on what are species. I have read heaps of agricultural and horticultural books and have never ceased collecting facts. At last gleams of light have come, and I am almost convinced (quite contrary to the opinion I started with) that species are 
not (it is like confessing a murder) immutable. Heaven forfend me from Lamarck nonsense of a tendency to 'progression,' 'adaptations from the slow willing of animals,' etc. But the conclusions I am led to are not widely different from his, though the means of change are wholly so. I think I have found out (here's presumption!) the simple way by which species become exquisitely adapted to various ends."

In the preface to the Origin of Species, published in I859, he outlined his plan of work in the following words :

"When on board H. M. S. Beagle as naturalist, I was much struck with certain facts in the distribution Darwin's method. of the organic beings inhabiting South America, and in the geological relations of the present to the past inhabitants of the continent. These facts seem to throw some light on the origin of species, that mystery of mysteries, as it has been called by one of our greatest philosophers. On my return home it occurred to me (in 1837 ) that something might perhaps be made out on this question by patiently accumulating and reflecting on all sorts of facts which could possibly have any bearing on it. After five years I allowed myself to speculate on the subject, and drew up some short notes. These I enlarged in 1844 into a sketch of the conclusions which then seemed to me to be probable. From that period to the present day I have steadily pursued the same object. I hope that I may be excused for entering upon these personal details, as I give them to show that I have not been hasty in coming to a conclusion."

"Mother Nature," says Huxley, "is singularly obdurate to honeyed words. Only those who understand the ways of things, and can silently and effectively use them, get much good out of her." 
Let me speak of certain traits of this work, the Origin of Species, which give it a position almost alone The Origin of Species. among books of science. There is in it no statement of fact of any importance which, during the nearly forty years since it was first published, has been shown to be false. In its theoretical part there is no argument which has been shown to be unfair or fallacious. In these forty years no serious objection has been raised to any important conclusion of his which was not at the time fully anticipated and frankly met by him. Indeed, there are but few of these objections which with our present knowledge are not much less weighty than Darwin then admitted. The progress of science has bridged over many chasms in the evidence.

There is in this work nowhere a suggestion of special pleading or of overstatement. The writer is a judge and not an advocate, and from his decisions there has been no successful appeal. There is in this or any other of Darwin's works scarcely a line of controversial writing. He has been the faithful mirror of Nature. The relations of Nature to metaphysics he has left to others. The tornados which have blown about the Origin of Species are not his work. He felt, perhaps, that most systems of philosophy are like air plants which thrive equally well in any soil; with just facts enough for their roots to cling to, they may grow and bloom perennially, without other food than the air.

The "Darwinian theory," as resulting from these many years of gathering of facts, may be briefly stated as follows: The various species of aniThe Darwinian theory. mals and plants now on the earth are the descendants of pre-existing forms which have in various ways undergone modification. The homologies existing among them are the result of 
inheritance from their common ancestry. The differences have come about through various natural influences, chief among which is the competition in the struggle for existence between individuals and between species, whereby those best adapted to their surroundings live and reproduce their kind. Any advantage of the individual, no matter how small, must be a help in its life struggle. This advantage inherited becomes the gain of the species. The various influences connected with this struggle were summed up in the comprehensive term of "natural selection," or, as Mr. Herbert Spencer has termed it, "the survival of the fittest." The latter term is, however, only half as large as the former, because "the survival of the existing" is in many regards a factor as potent as the actual survival of the fittest. To be on the ground is a factor not less important in determining survival than to have a special fitness for the conditions of life. The epithet "natural" in natural selection is also of vital importance as distinguished on the one hand from "artificial," or produced by human agency, and on the other hand from "supernatural," or produced by unknowable agencies. "Fitness" in this sense of course means simply the power to win in the particular kind of contest that may be in question, no moral element and no element of general progress being necessarily involved. The term "natural selection" originated from the use of the word "selection" by breeders of animals to indicate the process of "weeding out" by which they improve their herds. For the method by which in Nature a new species is brought into existence seems to be precisely parallel to that by which we may artificially produce a new breed of cows or of dogs, a new race of pigeons, or a new variety of roses. The record of man's work in the creation of species covers some of the most glorious of human achievements, none the less won- 
derful because they have taken place before our very eyes. To know the laws of heredity and to select domestic animals and plants so to reach our ends in accordance with these laws is indeed a creation. Artificial Artificial selection. selection, says Youatt, is the "magician's wand" by which the breeder can summon up whatever animal form he will. One might, according to Somerville, chalk out on the wall the form of sheep he most desired, and then develop it by attention to selection of parentage. The processes of heredity would bring this about by laws as unvarying as that by which a stream is forced to turn a mill. Professor Goodale tells us that were all our fruit trees destroyed and the species exterminated, they could all be won back again by the selective culture of wild pomes and berries.

"Natural selection" is, however, an affirmative Natural selection. phrase for what is largely a negative process. "Natural extinction," or the destruction of the unfittest, would sometimes express the same idea better.

No more striking statement of the universality of the struggle for existence and of its power to compel some form of selection-natural, of course-has ever been made than that given by Darwin in the Origin of Species. From this I quote:

"I use this term, struggle for existence, in a large and metaphorical sense, including dependence of one The struggle for being on another, and including (which existence. is more important) not only the life of the individual, but success in leaving progeny. Two canine animals, in a time of dearth, may be truly said to struggle with each other which shall get food and live. But a plant on the edge of a desert is said to struggle for life against the drouth, though more 
properly it should be said to be dependent upon the moisture. A plant which annually produces a thousand seeds, of which only one on an average comes to maturity, may be more truly said to struggle with the plants of the same and other kinds which already clothe the ground. The mistletoe is dependent on the apple and a few other trees, but it can only in a far-fetched sense be said to struggle with these trees for if too many of these parasites grow on the same tree it languishes and dies. But several seedling mistletoes growing close together on the same branch may more truly be said to struggle with each other. As the mistletoe is disseminated by birds, its existence depends upon them; and it may metaphorically be said to struggle with other fruitbearing plants in tempting the birds to devour and thus disseminate its seeds. In these several senses, which pass into each other, I use for convenience' sake the general term of "struggle for existence.'"

Darwin says that there is nothing which people are more willing to concede than the struggle for existence, and yet nothing can be more inadequate than the ordinary conception of it. He further says :

"A struggle for existence inevitably follows from the high rate at which all organic beings tend to increase. Every being, which during its natural lifetime produces several eggs or seeds, must suffer destruction during some period of its life, and during some season or occasional year; otherwise, on the principle of geometric increase, the numbers would quickly become so inordinately great that no country could support the product."

It is one of the axioms of mathematics that any geometrical progression will in time outrun any arithmetical one. Multiplication outruns addition.

"Hence . . there must in every case be a struggle for existence, either one individual with another of the 
same species, or with the individuals of distinct species, or with the physical conditions of life. It is the doctrine of Malthus applied with manifold force to the whole animal and vegetable kingdoms; for in this case there can be no artificial increase of food, and no prudential restraint from marriage. Although some species may be now increasing, more or less rapidly, in numbers, all can not do so, for the world would not hold them. There is no exception to the rule that every organic being naturally increases at so high a rate that if not destroyed the earth would soon be covered with the progeny of a single pair. Even slow-breeding man has doubled in twenty-five years, and, at this rate, in less than a thousand years there would literally not be standing room for his progeny. ... The elephant is reckoned the slowest breeder of all known animals, and I have taken some pains to estimate its probable minimum rate of increase; it will be safest to assume that it begins breeding when thirty years old, and goes on breeding until ninety years old, bringing forth six young in the interval, and surviving till one hundred years old; if this be so, after a period of from seven hundred and forty to eight hundred and forty years there would be nearly nineteen million elephants alive, descended from the first pair."

Darwin continues: "I have found that the visits of bees are necessary for the fertilization of some kinds of Relation of bees clover; for instance, twenty heads of to clover.

white clover (Trifolium repens) yielded two thousand two hundred and ninety seeds, but twenty other heads protected from bees produced not one. Again, one hundred heads of red clover (Trifolium pratense) produced two thousand seven hundred seeds, but the same number of protected heads produced not a single seed. Humble-bees alone visit red clo- 
ver, as other bees can not reach the nectar. ... Hence we may infer as highly probable that, if the whole genus of humble-bees became extinct or very rare in England, the heartease and red clover would become very rare or wholly disappear. The number of humble-bees in any district depends in a great measure on the number of field mice, which destroy their combs and nests; and Col. Newman, who has long attended to the habits of humble-bees, believes that more than two thirds of them are thus destroyed all over England. Now the number of mice is largely dependent, as every one knows, on the number of cats; and Col. Newman says, 'Near villages and small towns I have found the nests of humble-bees more numerous than elsewhere, which I attribute to the number of cats that destroy the mice.' Hence it is quite credible that the presence of feline animals in large numbers in a district might determine, through the intervention first of mice and then of bees, the frequency of certain flowers in that district."

Huxley carries this calculation still further by showing that the number of cats is dependent on the number of unmarried women. On the other Relation of cats hand, clover produces beef, and beef to England's greatness. strength. Thus in a degree the prowess of England is related to the number of spinsters in its rural districts. This statement would be true in all seriousness were it not that so many other elements come into the calculation. But whether true or not, it illustrates the way in which causes and effects in biology become intertangled.

The calculation has been lately made by Prof. Rufus L. Green that at the normal rate of increase from a pair of English sparrows, if none were to die except of old age, it would take but twenty years to give one sparrow to every square inch in the State of Indiana. But such 
increase is actually impossible; for more than a hundred other species of similar birds are disputing the same territory, and there can not be place or food for all. With The equilibrium of Nature.

such conditions, the struggle for existence between sparrow and sparrow, and between sparrows and other birds, grows yearly more severe. Each year now the sparrow gains a little and other birds lose correspondingly, but sooner or later with each species a point will be reached when the loss exactly balances the increase. This produces a condition of apparent equiliibrum-the equilibrium of Nature; a sort of armed neutrality which a superficial observer mistakes for real peace and permanence. But this equilibrium is broken as soon as any individual or group of individuals appears that can do something more than merely hold its own in a struggle for existence.

It is thus evident that throughout all Nature the number of organisms born into life is far in excess of the number of those which can come to More organisms born than can mature.

maturity. In every species the majority never reach their full growth, and this is because, for one reason or another, they can not do so. All live who can. Nature asks each organism, Why should you live? And those who can not give an answer pass away. "So careful of the type she seems; so careless of the single life." It is also evident, to use the language of Professor Bergen, that "the killing will not be indiscriminate, but it will first and mainly comprise those individuals which are least able to resist the attack." It is this "weedingout " process in Nature, this " natural selection," which in Darwin's view constitutes the essential cause of change and progress. Of the many possible illustrations of the action of "natural selection," one may serve our purpose at present. 
In the eastern United States there are two native species of hare or wild rabbit. These are the gray rabbit

How the hare becomes white. or "cotton-tail" (Lepus sylvaticus) of the region south of Pennsylvania, and the white rabbit (Lepus americanus) of the woodlands of the North. The southern hare is smaller than the other; it is much less shy, and its winter dress is not very different from its summer dress, the fur which comes in after the autumn shedding being of the same grayish colour. The northern hare is in summer not very different in colour from the other, but when it renews its fur in the fall its winter coat is pure snowwhite. There are some other distinctions between the two species, but we need notice simply the difference in colour as showing the principle of " natural selection." We may presume the two species to have had one common origin, probably in a form not very different from the gray rabbit as we know it. In every dozen rabbits which we may examine we shall find a considerable variation in shade of colour. Some will be darker than the average, some grayer, some browner, and others evidently paler. We shall find also differences in size and proportions, besides other differences, but for the present we need only consider the matter of colour. In the South, where the ground is mostly free from snow, even in winter, whiteness would be of no sort of advantage to a rabbit. The nearer the animal is in colour to the dead grass and dried leaves about him, the better are its chances of escaping detection, the greater the likelihood that it may elude its enemies and live out its days, leaving descenda11ts to inherit its peculiarities.

Not so with the northern species. The nearer it is in winter to the colour of the snow, the less likely it is to fall a prey to carnivorous animals or birds. And so for ages in the northern winter the action of competition in 
Nature, of "natural selection," has saved the whiter rabbits and condemned the darker ones to destruction. In the summer these conditions are changed; those individuals who retain the ancestral gray are then the ones best fitted to live. And so after many centuries, as we may conceive, there has come about a gradual change in the fur of our hares, until now in the northern species the fur is white in winter, while all are alike gray or brown in the summer.

Precisely similar is the change in the plumage of the arctic partridge, or ptarmigan, as well as in the various other northern birds. But this is not all. A change in colour such as enables the hare or the ptarmigan to evade its pursuers would also aid these pursuers to steal unaware on their prey. Nature has no preferences, and helps alike victim and victor. And so it comes about that predatory weasels and owls in winter assume a snow-white garb, and that this is laid aside in the summer. It is doubtless true that other influences co-operate in producing these changes in colour. White fur is warmest in cold weather, for it radiates less heat. We may say that all these animals are dressed in white in winter to keep them warm. But this again would be simply a phase of "natural selection." If the animals suffer from cold, the dark ones will be chilled first. Thus in more ways than one the white animal has the advantage of the other in the winter. This advantage enables it to outlive the other. It causes its descendants to outlive and eventually to displace those of its darker rival.

To such causes as these we must ascribe the nice adjustment of each species to its surroundings. If a species or a group of individuals can not adapt themselves to their environment, they will be crowded out by others who can do so. The former will disappear entirely from the earth, or else they will be limited to 
surroundings in which they come into perfect adjustment. A partial adjustment must with time become a complete one, for the individuals not adapted will be exterminated in the struggle for life.

Everywhere in Nature there is the closest adaptation of life to its conditions. But this adaptation How selection becomes adaptation.

must come about through the survival of those organisms fittest to live under these conditions, while the unfit die out and leave no progeny. Thus, in the words of Professor Bergen, "with much the same result as that which the farmer obtains by selecting his seed corn, the gardener by thinning out his beds, or the cattle-raiser by selling off his roughest calves for veal, Nature is at work on an inconceivably great scale, thinning out the least perfect individuals of each species."

But the thinning-out process is not the whole of "natural selection." Other influences work in connection with this. In the higher animals Acceleration of development. changes may be wrought by conscious or unconscious effort on the part of the creatures themselves, and the power to put forth such effort may be perpetuated by "natural selection." Certain organisms may carry their growth farther than their ancestors have done, so that the completed structures of their ancestors would be with them only a stage of development. And, as Professor Cope has shown, development may be hastened by the abridgment or omission of useless stages. Thus the ultimate maturity of the animal may be carried to a degree of specialization beyond that of its ancestry. If this "accelerated development" be for the gain of the species, "natural selection" will cause it to be retained. We may properly include under "natural selection" all those changes which come from the special use or disuse of any part 
of the structure. For "natural selection" must, in a way, be operative among the organs of the body. "Die Kampf der Theile," as it has been called by a German writer ("the battle of the parts"), is a real struggle in which fitness determines survival.

It is not merely the simple structures and the common instincts which may be developed and fixed by natural selection.

The differentiation of the sexes is a result of the demand for greater variation. It is the fact of bisexual

How bisexual parentage brings variety.

parentage that makes of each individual not simply an "elongation or continuance of the parent," but a new life which shall be the resultant of the lives and experiences of its ancestors, a mosaic of the characters of its parents and its parents' parentage. By the fact of sex no individual can be the mere slavish copy of any other. Through the operation of sex the law of heredity which is to promote sameness is made subservient to the equal need of the promotion of variety.

This idea, of the formation of the mosaic of personal character is the motive of Goethe's "Vom Vaterhab' famous poem, Vom Vater hab' ich die ich die Statur." Statur.*

* “Vom Vater hab' ich die Statur,

Des Lebens ernstes Fuhren;

Vom Mutterchen die Frohnatur

Und Lust zu fabuliren.

Urahnherr war der schönsten Hold,

Das spukt so hin und wieder.

Urahnfrau liebte Schmuck und Gold,

Das zuckt wohl durch die Glieder.

Sind nun die Elemente nicht

An dem Complex zu trennen;

Was ist denn an dem ganzen Wicht

Original zu nennen?"-Goethe, Zahme Xenien, vi. 
Again, the fact of death has been shown by Weismann to be a simple necessity of the law of natural seThe value of death.

lection. Creatures of one cell are in a sense biological units; they may be killed but they do not die a natural death. They are wholly alive or else wholly dead : never dying. They multiply by self-division, and this process is supposably eternal, for natural death is known only among many-celled or colonial organisms. It is a necessity arising from complexity of organization. Complication and specialization of structure as we know it in man and the other many-celled creatures is bought at the cost of mortality. These cells grouped in tissues and organs in one part or another must suffer in the struggle for existence. Every compound animal is in some part dead or dying. The old and mutilated organisms cumber the way of the young and fresh ones, and by the law of selection it comes about that for these to die of old age is useful to the species. Those species in which old age brings decay and in which the individuals perish naturally when they cease to be self-dependent are then preserved in the struggle for existence.

It is common in these days to speak of altruism as a means of doing away with the struggle for existence

Altruism and the struggle for existence. among men. But altruism itself is only a higher or more advanced result of the same struggle. Those who band together win, be they wolves or men, and natural selection favours those qualities which make for mutual advantage. To band together against enemies or for protection from the elements is a most effective way in which the struggle for existence may be carried on. The law of love is not an abrogation of the law of struggle. It represents a better way to fight. The conquests of science are simply the first results of co-opera- 
tion. If we "put our heads together" we may know or do everything. If we stand apart we can do nothing, and in the struggle for existence those who can stand shoulder to shoulder loyally have the promise of the future. Those who can not hold together find every man's hand raised against them. This principle holds good whether applied to the directors of a hospital or to a band of wolves.

Whatever form the struggle for existence may take, it is a permanent factor in all operations of life. Each creature must take part in a threefold struggle-with like forms of life, with unlike forms of life or creatures unlike itself, and with the conditions of life themselves. Each man must, whether he will or not, compete with his neighbours, must compete with other creatures, and must be judged by the conditions of food, climate, and environment under which life exists. Sometimes one element will determine, sometimes another. In the city one competes with his neighbours, in the jungle with the beasts, and in the arctic with the elements of cold and storm. In a similar way each animal has to justify its existence. Co-operation may modify and dignify the struggle for existence among men, but it can not set it aside. It may change its point of incidence, but it can not reduce its stress. Were it not for this struggle, which calls out from each generation its best and strongest for life purposes, there could be no progress in life. Without competition there could be no adaptation, without selection there would not be a creature on earth to-day higher than a toadstool!

It was a favourite saying of Agassiz that "Facts are stupid things until brought into connection with some general law." The law of descent, with change through "natural selection," brings into organic connection a host of facts hitherto isolated. Each one considered by 
itself would be without meaning or explanation. The essential argument in favour of "Darwinism" is that it brings all biological facts into unison from whatever field of investigation these facts may be derived. How-

Every fact has a meaning.

ever much evolutionists have at times seemed to drift away from Darwin's conclusions, it is always the most accurate research and the sanest thought which come nearest the opinions set forth in the Origin of Species. The body of facts has grown enormously year by year, but the conclusions we must accept are substantially those laid down by Darwin himself.

The facts of "geographical distribution," for example, have a meaning to us when we view them as the

Geographical distribution. results of centuries of the restlessness of individuals. Each species of animal or plant has been subjected to the various influences implied in the term "natural selection," and under varying conditions its representatives have undergone many different modifications. Each species may be conceived as making each year inroads on territory occupied by other species. If these colonies are able to hold their own in the struggle for possession they will multiply in the new conditions and the range of the species becomes widened. If the surroundings are different, new species or varieties may be formed with time, and these new forms may again invade the territory of the parent species. Again, colony after colony of species after species may be destroyed by other species or by uncongenial surroundings.

Only in the most general way can the history of any species be traced; but, could we know it all, it would be as long and eventful a story as the history of the colonization and settlement of North America by immigrants from Europe. Each region where animals or 
plants can live has been thousands of times discovered, its colonization a thousand times attempted. In these efforts there is no co-operation. Every individual is for himself, every struggle a struggle for life and death. To each species each member of every other species is an alien and a savage.

The study of geographical distribution shows the relations of creative processes to space. The forms in-

Survival of the existing. habiting one district are the children of the earlier inhabitants. The survival of these forms is due to that which I have elsewhere called the "survival of the existing," for it is certain that in any part of the world a totally different grouping of animals or plants would have been equally fitted to the environment. The laws of geographical distribution may be summed up thus: The reason why any given species of animal or plant is not found in a given district is $(a)$ because it could not get there from its own habitat, or $(b)$, being there, it could not maintain itself either in competition with others or from the stress of environment, or else $(c)$ it has in maintaining itself become altered into a distinct species.

In like manner the facts of geological distribution have a meaning when we view them in the light of the Geological distribution. theory of descent. The birth, increase, decline, and final change or disappearance of species or types in geological history are necessary parts of the Darwinian theory. They would be inexplicable on any other hypothesis. These changes represent the survival of the fittest as related to time. With the lapse of time come changes in environment, and these changes produce corresponding changes in animal or plant life. But these changes on the earth and in its life are for the most part gradual 
ones. The evolution of the earth and its life has rarely been subject to great leaps and catastrophes. Yet epoch-making events have taken place Epoch making events. on the earth. Such changes in life, as the acquisition of lungs, of wings, of speech, are marked by the increased rapidity of the processes of evolution.

Professor Bergen says: "Until an evolutionary rise of species had been assigned as an explanation of the succession of higher and higher animals and plants throughout the geological ages, what adequate reason for this progress of life could be given? Strike out from our present conception of the organic world, class after class, all notion of actual relationship by descent, and what have we left but a mighty host of extinct creatures whose rise, progress, and disappearance are far more unaccountable than that of the genii in the Arabian Nights?"

But not all change has been progress. The idea of some of the earlier evolutionists that the advance of

Change not progress. life has been the simple result of an innate "uniform tendency toward progression" can not be maintained. For progress, while general, is by no means uniform or universal. Progress ceases when its direct cause ceases. In every group there are some members characterized by degeneration and loss of specialization. This is involved in the theory of "natural selection." If progress comes through competition, lack of competition would imply retrogression. When animals or plants are withdrawn from the stress of life to some protected condition, the character of the type is lowered. There is less need for specialization when the range of wants is narrowed. Hence it is that all parasitic animals or plants-lice, leeches, dodders, mistletoe, Indian pipe-are 
degenerate forms. So it is with cave animals, as well as with most organisms of the deep sea or the far North. All forms which are withdrawn from open competition to a solitary and secluded life lose one by one the advantages which competition has gained for them, and are known as degenerate types. What is true of the lower animals is likewise true of man. The highest type of manhood, of human powers and human virtues, will come from victory in the struggle for existence and not from withdrawal from the struggle. Easy living always brings degeneration. The sheltered life is the source of weakness. The desire to get something for nothing is the bane of human society.

Parallel with the case of general degeneration of type is that of the degeneration of individual parts of the Vestigial organs. organism. An organ well developed in one group of animals or plants may in some other be reduced to an imperfect organ or rudiment so small or incomplete as not to perform its normal function, or, indeed, to serve any purpose whatever. Such rudimentary or functionless structures may be found in the body of any of the higher animals and in most or all of the higher plants. The appendix vermiformis and the unused muscles of the ears in man are examples. Such are also the atrophied lung, pelvis, and limbs of the snake, the "thumb" of the bird, the splint bone of the horse, and the like, without mentioning less familiar internal organs. By the theory of descent we may understand how much structures may be retained by the action of the law of heredity, while their reduction may be the result of long-continued disuse, or the growth and selection of other organs at the expense of these which are no longer needed.

Among a multitude of examples I need refer especially to but one-a recent discovery in homology. 
Within the brain of man, resting on the optic lobes, is a little roundish structure scarcely larger than a pea, The pineal eye. known as the pineal "gland" or "conarium." It has no evident purpose or function, and a philosopher once suggested that it might be the seat of the soul. It is larger in the embryo, and still larger in the brains of some of the lower vertebrates. Recent investigations have shown that it is especially de-

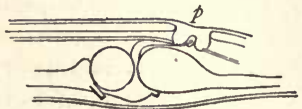

Fig. 1.-Pineal body in the lizard (Hatteria) developed as rudimentary eye; $p$, pineal eye. After Spencer. veloped in certain lizards, and that in them it ends in a more or less perfect eye, which is placed between the others in the centre of

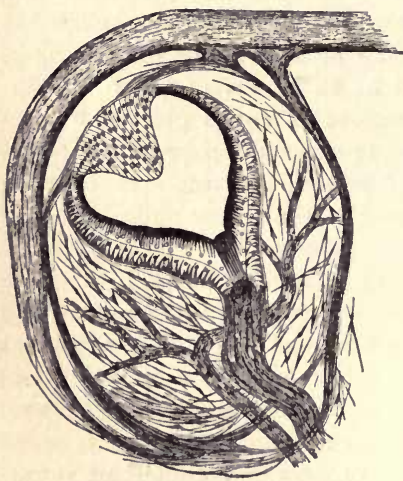

Fig. 2.-Pineal eye of the lizard (Hatteria). After. Spencer. the forehead. These lizards have in fact three eyes, and the pineal body is the optic nerve of the third. In the common horned toad the pearl-like scale above the pineal eye can be readily recognised. The shrunken rudiment found in man is therefore what is left of an ancestral third eye, probably once characteristic of vertebrates, but now displaced and destroyed by the increased development and greater perfection of the outer pair. By the theory of descent the presence of the pineal body in man is a simple result 
of heredity. If, however, man possessed no "blood relationship" to three-eyed vertebrates, the existence of

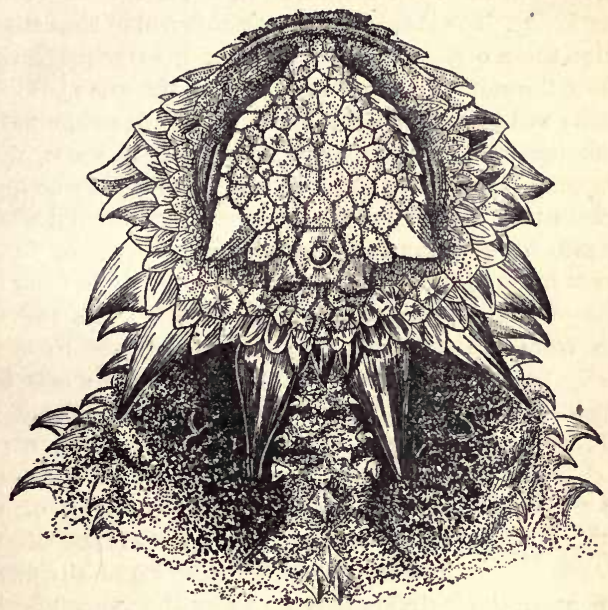

Fig. 3.-Head of the lizard, or "horned toad" (Phrynosoma blanivillei), showing the translucent pearly scale covering the pineal eye. From Nature, by W. S. Atkinson.

the pineal body in the human brain would be wholly inexplicable.

It has been difficult to explain, on the theory of descent, how complex organs like the eyes and ears of the Origin of complex structures. higher animals could develop from small beginnings. To embryology we must look for explanation. Embryology tells us that these organs do not in the individual reach perfection "all at once." In every case the embryonic history of a highly specialized organ shows a succession of 
stages of incompleteness before the organ is finished. Each of these stages finds a more or less perfect representation in the adult condition of some animal of less complexity. The long-continued "survival of the fittest" brings these organs to a greater and greater perfection. But by the side of these creatures with the most complex organs will be found those in which the development of some particular part may be less and less complete. An organ highly developed in one animal may be quite rudimentary and imperfect in some other animal whose superior fitness may be in some other direction. Thus fitness for underground life relieves the mole from the need of good eyes. Skill to live by his wits relieves man from the need of the monkey's power to climb trees. Somewhere in the animal kingdom we may find each degree of each organ's development. These organs in their varying degrees of complexity correspond more or less perfectly to the

The individual repeats the history of the race. several stages of development of the same organ in the individual of the highest type. The record of the development of the individual is in a way the recapitulation of the past history of its species. "The physical life of the individual is an epitome of the history of the group to which it belongs." Thus the embryonic life of man corresponds, so far as we can trace it, to the history of that branch of the group of vertebrates which has culminated in man. Each individual lives over again the life of the race. "Under each grave lies a world history,"* says a German proverb. This fact is, however, no mysterious or meaningless law. It is simply a natural result of the processes of heredity. Heredity repeats that which has been, and natural selection suppresses

* "Unter jedem Grab liegt eine Weltgeschichte." 
that which is injurious. The process of development of any individual is that of its ancestors with the harmful stages abbreviated or suppressed. The young frog has the ancestral gill of the fish and so has the human child in embryo. This stage is useful to the frog; it is not harmful to the unborn child. It is thus retained by heredity, but its retention is always governed by its possible harmfulness.

It is not an easy task to put in a few words and popular Ianguage even a hint of the wealth of evidence which Embryology and evolution.

embryology brings to the support of the theory of evolution. This evidence was in Mr. Darwin's mind the most convincing of all evidence, its force being even stronger than that derived from his own studies in geographical and geological distribution. In this connection the following paragraphs have been contributed by Dr. John Sterling Kingsley :

"To appreciate the weight and extent of embryological evidence. one needs the special training of the biological laboratory, for it is only by watching the wonderful changes which every egg goes through in its development that one can begin to realize the importance of the facts. The training of the metaphysician is here of no value, for it is not of the slightest avail in weighing the evidence.

"To state this evidence briefly, we may state that the history of every developing egg and embryo is utterly incapable of explanation from any other standpoint than that of evolution. Why should the young vertebrate have kidneys like those of worms? Why does man have muscles to move the ears? Why do young spiders develop legs which will utterly disappear in the adult? Why does the nervous system communicate with the alimentary canal in the young frog or bird? 
All of these questions, and thousands more which will suggest themselves at once to every student of embryology, are problems which receive no adequate explanation on the supposition of special creations. With the theory of evolution as a basis, the answers are easy. They are inheritances from ancestral conditions. In the terms of evolution they remain because the history of the individual is a more or less detailed recapitulation of the history of the race.

"The truth of this assumption is easily tested. The conclusions of embryology must be in full accord with those of geology, or one or the other must be wrong. In the rocks we have an indisputable record of the succession of the forms of life, and the conclusions of embryology must point to a similar succession.

"While neither our limits nor the character of the present article will allow anything like a discussion of the embryological evidence in support of evolution, a few examples will serve to indicate its character.

"In the development of all eggs the earlier stages are essentially alike, or easily reducible to a common

Similarity of early stages in embryonic life. type. It is only in the later stages that the variations occur that are to convert one egg into a fish, another into a chicken. There are, it is true, minor differences from the start, but these are largely to be explained on mechanical grounds. An egg differs from the other cells in the tissues of the parent chiefly in its capacity to reproduce the species. It divides again and again, and the resulting cells build anew the parent form, but in the character of this division or 'segmentation' many variations are recognised. In some the eggs are small and composed entirely of protoplasm, and here the segmentation is regular, but other eggs are larger, and this increase in size is due to the addition of 
a larger amount of 'food yolk' stored up to supply the wants of the growing embryo till the time comes when it shall be able to shift for itself. Protoplasm is active, 'food yolk' passive, and the relative amounts of these two and the positions which they occupy in the egg affect, in a purely mechanical manner, the segmentation, and interfere with or destroy its typical regularity. In the egg of the common hen this 'food yolk' forms almost the whole of the yolk, the really important protoplasm occurring only in the lighter yellow spot, which is always uppermost in the egg. Taking it for granted that this amount of food yolk influences the character of the early stages of development (a point easily proved by the embryologists), let us consider a special case in which conclusions drawn from development have received later confirmation from other sources.

"In the mammals the eggs are very small and consist of pure protoplasm, food yolk being entirely absent. The egg of the mammal.

Indeed, nourished by the mother, as the young of most of these forms are, no store of food yolk is necessary. Hence, on a priori grounds, one would say that the segmentation of the mammalian egg would be regular in its character. When, however, naturalists came to study the development of the mammalian egg, it was found that in its early stages it presented (in eggs without food yolk) some astonishing peculiarities. How to explain these peculiarities was a problem. If, however, it were assumed that the mammals have descended from forms with larger eggs, and that in the course of evolution they have lost the yolk but had retained the tendencies of development, the explanation were easy. This explanation, however, seemed very improbable, for it had been held, on grounds of structure, that the mammals must have descended from the batrachia, a group con- 
taining the frogs and salamanders, in which the eggs are not large enough to serve the conditions of the problem. So the matter was allowed to rest until new evidence should be found. It came in r864. In that year Professor Cope found the remains of certain reptiles in the rocks of Texas which he, not being aware of the embryological problem, stated must be regarded as the ancestors of both birds and mammals. His evidence was solely derived from the bony structure. As all reptiles have eggs in which there is a large amount of food yolk, this discovery answered all the requirements of the problem. Both embryology and geology were in full accord. But the end was not yet. In the same year, and a few weeks later, Caldwell and Haacke discovered that two of the species of monotremes, those wonderful bird-like mammals for which Australia is noted-the duckbill and the spiny ant-eater-do not nourish their embryos like other mammals, but that they, like birds, lay eggs. It was found, further, that these eggs are large; they contain a large amount of food yolk, and they develop at first in the same way as the eggs of reptiles. Here was additional confirmation of the embryological conclusions.

"There are many other features in the development of the mammals which are equally wonderful and con-

Embryonic structures in man. clusive of the truth of the theory of evolution. According to the geological record, man must be descended from mammals with tails. We find that in the early stages of the embryo of man there is a time when there exists a regular tail supported by eight distinct bones, like the tail bones of any other mammal. With growth, however, these bones unite and all disappear except three, which, joined in one, persist in the adult. On the theory of evolution this tail is easily ex- 
plained; special creation can not account for it. Going still further back in the history of the development of the mammals, the record shows that both these and the Gill slits in man. reptiles must have arisen from fish-like forms which breathed water by means of gills. To this embryology offers ample support. In the embryos of reptiles, birds, and mammals, soon after the heart is formed, there appear on the sides of the neck openings which in both origin and structure resemble the gill arches of fishes, and through these gills the blood flows exactly as it does in the fish. Later the gill arches close up, the blood takes other courses, and of all the complicated apparatus which persists throughout life in the fish there remain only a few obscure traces in the adult reptile, bird, or mammal."

This fact must show that the higher mammals have had a water-breathing, fish-like ancestry. Only the force of heredity can explain the existence and retention of these structures. On any other supposition an explanation is inconceivable.

Dr. Kingsley further says: "These examples are but a tithe of the evidence; thousands of pages might be written detailing similar facts not only in connection with the embryology of the vertebrates but of all groups of animals and plants. Every case would lead us to the same conclusions, but except for the special student of biology they would have but little interest. Each instance would be inexplicable except upon an evolutionary basis, but, if one adopt the hypothesis that the history of the individual is an epitome of that of the race, all is at once as clear as day. Special creation is utterly inadequate to explain embryological problems; evolution leaves no room for doubt or question."

The difficulties and objections to the theory of descent will be found in the Origin of Species, stated by 
Darwin himself with a fullness, fairness, and clearness which none of his opponents has been able to reach.

Objections to the theory of descent.

Increasing knowledge has steadily diminished the apparent value of these objections. None of them can now be regarded as of any serious importance. Our chief questions as to the origin of species relate to the relative importance of the various elements which enter into "natural selection," to a better definition of the laws of variation, and especially to the existence of a possible unknown factor in evolution which causes the transmission of the results of the efforts and experiences of the individual.

Just now evolutionists are nearly equally divided on this great question, on which even their conventional beliefs have been lately rudely shaken. Relation of pres- Are acquired characters ever inherited, ent heredity to past environment. and, if so, under what conditions and limitations? Is the experience of the parent part of the heritage of the child? Does the environment of the father enter into the heredity of the son? Are the reactions which follow the various external conditions restricted to the individual alone, and is the next generation untouched by its parents' successes or failures, as though it were a new creation?

To ask these questions is not to answer them, and and the final solution of the relation of present heredity to past environment will be the work of the student of the twentieth century.

Darwin's work was addressed at first only to naturalists, with no expectation that the public would pay any Darwin's hope. attention to it. He had confidence that the younger and more observant of his fellow workers would find in their own work confirma- 
tion of his conclusions. The times were riper than he had realized. He has outlived nearly all his scientific opponents, the greatest and perhaps the last of whom was Agassiz. To-day there is not one whose scientific studies have been such as to give him a right to speak, whose views are not in substantial accord with those of the Origin of Species. Darwin's work has destroyed forever the closet-formed idea of a "species" in biology as something fundamentally different from a variety or a race.

Let me take an illustration. Camille The species of eel.

Dareste, writing of the hundred or more alleged species of the true eel (Anguilla), says :

"There are at least four distinct types, resulting from the combination of a certain number of characters; but the study of a very large number of specimens belonging to these four specific types has convinced me that each of these characters may vary independently, and that, consequently, certain individuals exhibit a combination of characters belonging to two distinct types. It is therefore possible to establish clearly defined barriers separating these two types. The genus Anguilla exhibits, then, a phenomenon which is found in many other genera, and even in the genus Homo itself, and which can be explained in only two ways: Fither these four forms have had a common origin and are races merely, and not species; or else they are distinct in origin and are true species, but have been more or less commingled, and have produced by their mingling intermediate forms, which co-exist with those which are primitive. Science is not in the position to decide between these two alternatives."

It is on idle problems like this as to the reality of species that the strength of the naturalists of the past 
century has been largely wasted. Which of the forms we study are species, and therefore represent separate acts of the Creator, and which are mere varieties, chance The reality of species. products of varying surroundings, and therefore to be despised and ignored? Scarcely ever did two earnest students of any group reach an agreement as to this question, for agreement is only possible when material is lacking. A single additional specimen of ten unsettles every conclusion, and the contents of all the museums are but the slightest fragment of the life of the globe. "We can only predicate and define species at all," says Dr. Coues, "from the mere circumstance of missing links. Our species are twigs of a tree separated from the parent stem. We name and arrange them arbitrarily in default of means of reconstructing the whole tree in accordance with Nature's ramifications." Among Dareste's eels we may have one species, or four, or forty, as our collection may be deficient in connecting forms, or as we may choose to magnify or disregard slight differences. There are just as many kinds of eels as there are races of men or of dogs. Future naturalists will again describe those eels; but they will know them for what they are-the varying descendants of some one degenerated type of fishes, crawling in the weeds and ooze of many seas and rivers, and thus variously modified by their surroundings.

Meanwhile the old notion of a species has passed away forever. We can no more return to it than asThe old idea of species has passed away. tronomers can return to the Ptolemaic notion of the solar system. The same lesson comes up from every hand. It is the common experience of all students of species. I do not know of a single naturalist in the world who has made a thoughtful study of the relations 
of species in any group who entertains the old notion as to their distinct origin. There is not one who could hold this view and look an animal in the face!

And for this change we have to thank Darwin. "It is easy to plough where the field is cleared," and what he first of all saw clearly we can not fail to see now. The fact is that every student of species and of the facts of geographical distribution has reached, willingly or unwillingly, the conclusion that species are not immutable; that those differences by which he tried to discriminate the groups of organisms which he calls species were not differences originating in the act of creation, but produced in some way by outside influences or by the organism's reaction in adjustment to these influences. One might safely pledge himself to convert to some phase of the development theory any honest and intelligent man who would spend a month in a careful study of a large collection of specimens in any group in which the existing species are found over wide areas on the surface of the earth. The study of squirrels, eels, catfishes, pine trees, asters, butterflies, clams, snails, horses, or men-any of these will serve to accomplish this purpose.

The general acceptance of the Darwinian theory by naturalists is not due exclusively to the Origin of Species or to any of the numerous comThe acceptance of the theory of descent. mentaries and expositions which have come from other hands. It arises from the results of the studies themselves. No authority has compelled it, for Darwin's influence was not, like that of Cuvier or of Agassiz, the force of an overmastering personality. He was rather the voice of Nature. His word was the impersonal word of Nature herself. To see truthfully is to see with Darwin's eyes. The idea of development gives the only clew by which 
the naturalist can be guided in his work. If the affinities of species are not related to the law of heredity they are unintelligible. If the variation of species is really immutability in disguise we can not trust our senses. It is said, I know not on what authority, that the distinguished ichthyologist, Albert Günther, was converted to Darwinism by the study of the British salmon. Whether this is true or not, such a study could have no other effect. I was brought to the same beliefs through a study of the minnows and darters of the Mississippi Valley. In the study of species one must choose between some form of development theory on the one hand and a hopeless, unscientific, impossible ignorance on the other; and in all forms of biological investigation, comparative anatomy, morphology, embryology, histology, we reach the same choice of alternatives.

The theory of descent by "natural selection" has become in the hands of Herbert Spencer a part of a The philosophy of evolution. general philosophy of evolution, a conception much older in time than the theory of Darwinism. Manifestly we could not imagine a homogeneous universe or a homogeneous earth which could perpetually retain a homogeneous condition. A cooling earth must lose its perfect rotundity, its surface must become diversified, and its relation to the sun must cause its equatorial portion to become different from its poles. A single homogeneous form of life could not remain single and uniform, because life must respond to the conditions of its environment. Any organism under a tropical sun is not what it would be, exposed to arctic cold. Diversity once begun, and a rate of increase more rapid than a limited earth could permit unchecked, the natural competition in the struggle for existence accounts for the rest. 
The theory of evolution, in brief, is this: There exists in all things a tendency to become specialized and differentiated. In accordance with this tendency nebulous masses have been concentrated into planets and the generalized creatures of early time have been specialized into distinct forms. The formula of the process of evolution as stated by Mr. Spencer resolves itself into this: "Evolution is a change from an indefinite, incoherent homogeneity to a definite, coherent heterogeneity through successive differentiations and integrations."

That this is true in the world of life is beyond question, and we have reason to believe that something of the sort is true in the world outside of life, whether the laws and forces in question be in essential respects comparable or not.

The influence of the theory of descent on all forms of modern mental activity has been great beyond comInfluence of theory of descent.

parison. The thoughts of every student have been more or less modified by it. In philosophy as in science the publication of the Origin of Species has been the great event of the nineteenth century. Not only have all the strictly biological sciences undergone a complete transformation since the year 1859 , but such allied sciences as psychology, philology, sociology, and ethics have felt the same impulse and have fallen under the same influences. Even the organization of charities in every well-ordered community is avowedly based on the principles of Darwinism.

The various attacks on the theory of descent have been nearly all based on the question of the origin of Origin of man. man. For the human race is likewise a side it must be discussed with other species. If we suppose that the various forms of the lower animals and 
plants had their origin in pre-existing forms more or less different, we may presume this to have been true of man also. That it is true of man in fact we know, for not many thousands of years ago our ancestors in Europe were barbarians, cave dwellers, lake dwellers, and dwellers in hollow trees, using only the rude implements they shaped from metal and flint. The origin of civilized man from barbarous man gives the clew to the origin of barbarous man from forms still less specialized.

The question of the origin of man, though perhaps the most interesting problem in science, offers to the student of Nature peculiar difficulties. Materials for exact knowledge are few and prejudices are strong, and all tendencies favour an immediate decision on doubtful points, though the evidence be far from sufficient. Of not one man, nor monkey, nor bird, nor beast in half a million does a trace remain after a thousand years-not a bone, nor a relic, nor a thought. Living on the surface, we crumble into dust; and the current phases of human life, a few centuries out of hundreds, are all of man's history we surely know. Many links are missing still, and most of these we can never find. Our early ancestry we can best infer from our knowledge of the embryonic history and mental development of the man of to-day.

But if anything in science is certain, it is that homology is a fact, and that it has a meaning. Among us Meaning of homology. backboned animals, all structures, all functions, and all mental operations show distinct homologies. The essence of the development theory is this: Homology is the stamp of heredity. Homology means blood relationship. No other meaning of homology has ever been shown, nor is there the slightest evidence that any other interpretation is possible. Blood relationship implies a 
common action of heredity, and a common heredity is the only source yet known for the likenesses we call homology.

I resemble my neighbour so closely that people say we look like brothers. My little boy shows similar exactness of homology to me, and people say that he is the very image of his father. My neighbour on the left shows wider divergencies, but then he too is evidently an Anglo-Saxon. Angle or Saxon, we were all of one blood not many centuries ago. Still farther away the whole Aryan race becomes one, and we are willing in Adam to recognise our homology even with our poor relations-the Bushman and the Hottentot. But still poorer relations we have, and they too carry on their faces the unmistakable evidences of kinship by blood. In every bone and muscle my dog shows his likeness to me, and even in every function of his feeble little brain the resemblance is apparent. We have no explanation of such homologies other than that of kinship by blood. For this reason we know that the various races of men and the various species of monkeys have some time had a common ancestry. For this reason we believe that at a period of time far back in the geological record all vertebrate animals sprang from a common stock. We have substantially the same evidence, differing only slightly in degree, for believing that my dog and myself are related by blood in some form of distant cousinship, as there is to show a similar relationship between myself and any one of my neighbours. In neither case can we secure proof by appeal to history. Our records go back for a few generations only, and the great past is lost. In either case our acknowledged kinship is only an inference based on known facts of heredity and homology.

No two groups can show homologies with each other 
more clearly than the members of the highest order of mammals. Either these homologies are real and thus show the existence of a real bond of union, or else they are mere mockeries like the face in the pansy flower. If homologies are mockeries, then indeed our science has made no progress, for this was the belief of the middle ages.

So much for what we know. Our objections to recognising our kinship with the lower forms-if we have any such objections-rest on considerations outside the domain of knowledge. They do not rest on religious grounds. Those who think so deceive themselves. "Secondary causes," as the phrase is used, belong to the province of science. They are outside the domain of religion. "Theology and science," says Darwin, "should each run its own course. . . I am not responsible if their meeting point should still be far off."

This is not a question of preference one way or another. Personal preference has no place in science. Man was not present at the foundation of the world. It is not a question to be decided one way or another by a majority vote. Truth cares nothing for majorities, and the majority of one age may be the wonder or the shame of the next.

The only question is this: Is it true? And if it be the truth, nothing in the universe can be truer. "Ex-

Decaying scientific beliefs. tinguished theologians," Huxley tells us, "lie about the cradle of every science as the strangled snakes beside that of the infant Hercules." Looking along the history of human thought, we see the attempt to fasten to Christianity each decaying belief in science. Every failing scientific notion has claimed orthodoxy for itself. That the earth is round, that it moves about the sun, that it is old, that granite ever was melted-all these beliefs, now 
part of our common knowledge, have been declared contrary to religion, and Christian men who knew these things to be true have suffered all manner of evil for their sake. We see the hand of the Almighty in Nature everywhere; but everywhere he works with law and order. We have found that even comets have orbits; that valleys were dug out by water, and hills worn down by ice; and all that we have ever known to be done on earth has been done in accordance with law.

Darwin says: "To my mind it accords better with what we know of the laws impressed on matter by the Darwin's words. Creator, that the production and extinction of the past and present inhabitants of the world should have been due to secondary causes, like those determining the birth and death of an individual. When I view all beings, not as special creations, but as lineal descendants of some few beings who lived before the first bed of the Silurian was deposited, they seem to me to become ennobled.

"There is a grandeur in this view of life, with its several powers having been originally breathed by the Creator into a few forms or into one, and that while this planet has gone cycling on according to the fixed law of gravity, from so simple a beginning, endless forms most beautiful and most wonderful have been and are being evolved."

With the growth of the race has steadily grown our conception of the omnipotence of God. Our ancestors The conception of God. felt, as many races of men still feel, that they were forsaken unless each household had a god of its own, for, numerous as the greater gods were, they were busy with priests and kings. The people could hardly believe that the God of their tribe could be the God of the Gentiles also. That he could dwell in temples not made 
with hands, removed him from human sight. That there could be two continents was deemed impossible, for one God could not watch them both. That the earth was the central and sole inhabited planet rested on the same limited conception of God. That the beginning of all things was a little while ago is another phase of the same idea, as is the idea of special creation for every form of animal and plant.

A Chinese sage, whose words remain while his name is lost in the ages between him and us, has said: " $\mathrm{He}$ can not be concealed; he will appear without showing himself, effect renovation without moving, and create perfection without acting. It is the law of heaven and earth, whose way is solid, substantial, vast, and unchanging."

Not long ago I walked across the Kentish fields to Down, a pilgrim to the, shrine of Darwin. I saw the Darwin's home. stately mansion in which he lived-a great stone house surrounded by trees and shut in by an ivy-covered wall. I talked with the villagers of Down, the landlord of the George Inn, and the working people who had been his neighbours all their lives, and to whom Charles Darwin was not the worldrenowned investigator, but the kindly friend. His love for his wife and family, his love for flowers and birds and trees, his love for all things true and beautiful-all this forms the fair background before which rises the noblest work in science.

Forty years ago obloquy and derision were heaped upon the name of Darwin from all sides, sometimes even from his scientific associates. He outlived it all, and when he died his mother country paid him the highest tribute in her power. He lies in Westminster Abbey, by the side of Isaac Newton, one of the noblest of the long line of men of science whose lives have made his own 
life possible. For every truth that is won for humanity takes the life of a man.

Among all who have written or spoken of Darwin since he died, by none has an unkind word been said. His was a gentle, patient, and reverent spirit, and by his life has not only science but our conception of Christianity been advanced and ennobled.

"A sacred kinship I would not forego

Binds me to all that breathes; through endless strife

The calm and deathless dignity of life

Unites each bleeding victim to its foe.

"I am the child of earth and air and sea.

My lullaby by hoarse Silurian storms

Was chanted, and through endless changing forms

Of tree and bird and beast unceasingly

The toiling ages wrought to fashion me.

"Lo! these large ancestors have left a breath

Of their great souls in mine, defying death

And change. I grow and blossom as the tree,

And ever feel deep-delving earthy roots

Binding me daily to the common clay;

Yet with its airy impulse upward shoots

My soul into the realms of light and day.

And thou, $\mathrm{O}$ sea, stern mother of my soul,

Thy tempests ring in me, thy billows roll!"

HJalmar hjorth Boyesen. 
II.

EVOLUTION: WHAT IT IS AND WHAT IT IS NOT.

THIs is the age of evolution. The word is used by many men in many senses, and still of tener perhaps in

What

no sense at all. By some it is spoken evolution is.

with a haunting dread, as though it were another name for the downfall of religion and of social stability. Still others speak it glibly and joyously, as though progress and freedom were secured by the mere use of the name. "The word evolution (Entwickelung)," says a German writer, "fills the vocal cords more perfectly than any other word." It explains everything and "puts the key to the universe into one's vest pocket."

So various has been the use of the word, so rarely is this use associated with any definite idea, that one hesitates to call himself an evolutionist. "Evolution" and "evolutionist" are almost ready to be cast into that "limbo of spoiled phraseology" which Matthew Arnold has found necessary for so many words in which other generations delighted and which they soiled or spoiled by careless usage.

But as the word evolution is not yet put away, as it is the bugbear of many good people and the "religion" of as many more equally good, it may be worth while to consider what it still means and what it does not mean, for if we that use the word can agree on a definition half our quarrel is over. 
It seems to me that the word evolution is now legitimately used in four different senses. It is the name of a branch of science; it is a theory of organic existence; it is a method of investigation; and it is the basis of a system of philosophy.

As a science, evolution is the study of changing beings acted upon by unchanging laws. It is a matter of

The science

of organic

evolution.

common observation that organisms change from day to day, and that day by day some alteration in their environment is produced. It is a conclusion from scientific investigation that these changes are greater than they appear. They affect not only the individual animal or plant, but they affect all groups of living things, classes or races or species. No character is permanent, no trait of life without change; and as the living organism and groups of organisms are undergoing alteration, so does change take place in the objects of the physical world about them. "Nothing endures," says Huxley, "save the flow of energy and the rational order that pervades it." The structures and objects change their forms and relations, and to forms and relations once abandoned they never return; but the methods of change are, so far as we can see, immutable. The laws of life, the laws of death, and the laws of matter never change. If the invisible forces which rule all visible things are themselves subject to modification and evolution we have not detected it. If these vary, their aberrations are so fine as to defy human observation and computation. In the control of the universe we find no trace of "variableness nor shadow of turning." "It is the law of heaven and earth, whose way is solid, substantial, vast, and unchanging."

But the things we know do not endure. Only the shortness of human life allows us to speak of species or 
even of individuals as permanent entities. The mountain chain is no more nearly eternal than the drift of sand. It endures beyond the period of human observation; it antedates and outlasts human history. So does the species of animal or plant outlast and antedate the lifetime of one man. Its changes are slight even in the lifetime of the race. Thus the species, through the persistence of its type among its changing individuals, comes to be regarded as something which is beyond modification, unchanging so long as it exists.

"I believe," said the rose to the lily in the parable, "I believe that our gardener is immortal. I have watched him from day to day since I bloomed, and I see no change in him. The tulip who died yesterday told me the same thing."

As a flash of lightning in the duration of the night, so is the life of man in the duration of Nature. When one looks out on a storm at night he sees for an instant the landscape illumined by the lightning flash. All seems at rest. The branches in the wind, the flying clouds, the falling rain, are all motionless in this instantaneous view. The record on the retina takes no account of change, and to the eye the change does not exist. Brief as the lightning flash in the storm is the life of man compared with the great time record of life upon earth. To the untrained man who has not learned to read these records, species and types in life are enduring. From this illusion arose the theory of special creation and permanence of type, a theory which could not persist when the fact of change and the forces causing it came to be studied in detail.

But when man came to investigate the facts of individual variation and to think of their significance, the current of life no longer seemed at rest. Like the flow of a mighty river, ever sweeping steadily on, never re- 
turning, is the movement of all life. The changes in human history are only typical of the changes that take place in all living creatures. In fact, human history is only a part of one great life current, the movement of which is everywhere governed by the same laws, depends on the same forces, and brings about like results.

The facts and generalizations of change constitute the subject matter of evolution; and as the fact of life is a fundamental one and in some degree modifies all phenomena which it concerns, we have as the central axis of the science in question the study of organic evolution. In fact, while inorganic evolution or orderly change in environment also exists, we do not know to what degree the laws and forces of organic evolution can be reduced to the same terms of expression. The theory of the essential and necessary unity of life and non-life, of mind and matter, is still a matter of philosophical speculation only. We can neither prove the truth of Monism nor understand it ; nor is the contrary hypothesis either comprehensible or credible. The fundamental unity of organic evolution and inorganic evolution is likewise yet to be proved, while the laws which govern living matter are certainly in part peculiar to life. For this reason the evolution of astronomy, of dynamic geology, of geography, as well as the purely hypothetical evolution of chemistry, must be separated from life evolution. Cosmic evolution and organic evolution show or seem to show some divergence from each other. To regard them as identical is to introduce confusion and not order into our conception of evolution. There are some elements which are not held in common, or which at least are not identical when measured in human terms. It is not evident that any force in the evolution of life is homologous with any which has brought about the evolution of stars and planets. This 
unity of forces may be a philosophical necessity; it is not a fact.

For the science which treats of organic evolution we are in great need of a distinctive term. This need was Bionomics. met by Prof. Patrick Geddes, who suggested the term bionomics. Bionomics ( $\beta$ íos, life; vó $\mu$ os, law or custom) is the science which treats of the changes in life forms and of the laws and forces on which these changes depend.

Even as thus restricted, organic evolution, or bionomics, is the greatest of the sciences, including in its subject matter not only all natural history, not only processes like cell division and nutrition, not only the laws of heredity, variation, natural selection, and mutual help, but all matters of human history, and the most complicated relations of civics, economics, and ethics. In this enormous science, no fact can be without a meaning, and no fact or its underlying forces can be separated from the great forces whose interaction from moment to moment writes the great story of life.

And as the basis to the science of bionomics, as to all other science, must be taken the conception that nothing is due to chance or whim. Whatever occurs comes as the resultant of moving forces. Could we know and estimate these forces, we should have, so far as our estimate is accurate and our logic perfect, the gift of prophecy. Knowing the law, and knowing the facts, we should foretell the results. To be able in some degree to do this is the art of life. It is the ultimate end of science, which finds its final purpose in human conduct.

"A law," according to Darwin, " is the ascertained sequence of events." The necessary sequence of events it is, in fact, but man knows nothing of what is necessary, only of what has been ascertained to occur. Be- 
cause human observation and logic can be only partial, no law of life can be fully stated. Because the processes of the human mind are human, with organic limitations, Meaning of law. the study of the mind itself becomes a part of the science of bionomics. For it is itself an instrument or a combination of instruments by which we acquire such knowledge of the world outside of ourselves as may be needed in the art of living, in the degree in which we are able to practise that art.

The necessary sequence of events exists, whether we are able to comprehend it or not. The fall of a leaf follows fixed laws as surely as the motion of a planet. It falls by chance because its short movement gives us no time for observation and calculation. It falls by chance because, its results being unimportant to us, we give no heed to the details of its motion. But as the hairs of our head are all numbered, so are numbered all the gyrations and undulations of every chance autumn leaf. All processes in the universe are alike natural. The creation of man or the growth of a state is as natural as the formation of an apple or the growth of a snow bank. All are alike supernatural, for they all rest on the huge unseen solidity of the universe, the imperishability of matter and the immanence of law.

We sometimes classify sciences as exact and inexact, in accordance with our ability exactly to weigh forces and results. The exact sciences deal with simple data accessible and capable of measurement. The results of their interactions can be reduced to mathematics. Because of their essential simplicity, the mathematical sciences have been carried to great comparative perfection. It is easier to weigh an invisible planet than to measure the force of heredity in a grain of corn. The sciences of life 
are inexact because the human mind can never grasp all their data. The combined effort of all men, the flower of the altruism of the ages, which we call science has made only a beginning in such study. But, however incomplete our realization of the laws of life, we may be sure that they are never broken. Each law is the expression of the best possible way in which causes and results can be linked. It is the necessary sequence of events, therefore the best sequence, if we may imagine for a moment that the human words "good " and "bad" are applicable to world processes. The laws of Nature are not executors of human justice. Each one has its own operation and no other. Each represents its own tendency toward cosmic order. A law in this sense can not be "broken." "If God should wink at a single act of injustice," says the Arab proverb, "the whole universe would shrivel up like a cast-off snake skin." If God should wink at any violated law the universe would vanish.

Not long ago, in an examination in a theological seminary, the question was asked of the candidates for the ministry, "Is it right to pray for a change of season?" The candidates thought that it was not, for the relations which produce winter and summer are fixed in the structure of the solar system and can not be altered for man's pleasure or man's need. "Is it right to pray for rain ?" The candidates generally thought that it was, because the conditions of rain are so unstable that a little change in one way or another would bring rain or fair weather. It is proper to ask for such a change, as it does not concern the economy of the universe.

The third question was: "When the signal service of the United States is well established, so that weather conditions are perfectly known, will it then be right to 
pray * for rain?" And the candidates for the ministry could not tell, for they began to see that even simple changes of weather may have the strength of the whole universe behind them. It has never yet rained when by any possibility it could do otherwise. It has never failed to rain when rain was possible.

We hear good men say sometimes that the crying need of this sceptical age is that it may see some law of Nature definitely broken, that it may rain when rain is impossible, or that some burning bush may, unconsuming, proclaim that the force which is behind all law is also above it and can break or repeal all its own laws at will.

Emerson somewhere speaks of the purpose in life" to be sound and solvent." As his life was in all ways "sound and solvent," perhaps such Soundness and rule of conduct was his own. But one solvency of Nature. may say, This is only a human resolution. The man himself should be above all rules and requirements of his own making. Let Mr. Emerson show that his life is above his principles. Let him break these rules to show his power. Let him be "unsound and insolvent" for a time. Then only will his real greatness appear. But the soundness and solvency were the expression of Emerson's life. Without these he would not be Emerson.

The laws of Nature are the expression of the infinite soundness and solvency of the universe. They will not be broken, nor through their unsoundness and insol-

* " The essence of prayer is to bring two things into unisonthe will of God and the will of man. Superstition imagined, no doubt, that prayer would change the will of God, but the more spiritually minded have always understood that the will which must be modified in prayer was the will of man."-Bernard Bosanquet. 
vency will the "heavens roll away as a scroll," nor "the universe shrivel up as a cast-off snake skin."

In the growing recognition of law has lain the progress of science. From the casting aside of human notions of chance and whim the "warfare of science" has had its rise. For every fact carried over into the realm of law some man has given his life. Many a time in the growth of humanity it has been necessary that the wisest, clearest, most humane should die on the stake or the gibbet or the cross, that men should come to realize the power of an idea; that they should know the meaning of truth.

Many men have been distressed over the insensibility of Nature. She goes on with her own affairs. If The indifference of Nature. the ship leaks, she drowns a prophet as she would a rat. The stones in the street should have cried out at the murder of Cæsar. But they did not. It was only men who cried. Once, when a fugitive slave was seized in Massachusetts, there were those who felt outraged that Nature did not rebel against it. It was a surprise to Thoreau that the squirrels went on with their hoard and the wind rustled in the trees, as though nothing had happened. But what should Nature do? She attends only to her own affairs. She is only a figure of speech by which we personify her affairs. Her "just keeping on the same, calmer than clockwork and not caring," is the expression of the solidity of the universe. She is as indifferent as the multiplication table is, for the multiplication table is only another expression of unchanging law. A law of Nature is " no respecter of persons." A varying multiplication table would be the destruction of mathematics. A varying law of Nature would be the destruction of the universe.

The laws of evolution have in themselves no neces- 
sary principle of progress. Their functions each and all may be defined as cosmic order. The law of gravitation brings order in rest or motion. The laws of chemical affinity bring about molecular stability. Heredity repeats strength or weakness, good or ill, with like indifference. The past will not let go of us; we can not let go of the past. The law of mutual help brings the perpetuation of weakness as well as the strength of cooperation. Even the law of pity is pitiless, and the law of mercy merciless. The nerves carry sensations of pleasure or pain, themselves as indifferent as the telegraph wire which is man's invention to serve similar purposes. Some men who call themselves pessimists because they can not read good into the operations of Nature forget that they can not read evil.

For both good and evil belong to man's reaction from the influences of environment. It is the growth of love and wisdom through struggle and storm that makes this world the abode of righteousness. It is the effort of man that deifies Nature. It is this that raises the process of evolution above the level of the multiplication table. It is this that makes the whole of Nature greater than the sum of all her parts.

In a different sense the word evolution is applied to the theory of the origin of organs and of species by divergence and development. This theEvolution as a ory teaches that all forms of life now theory of organic development.

existing or that have existed on the earth have sprung from a common stock, which has undergone change in a multitude of ways and under varied conditions, the forces and influences producing such change being known as the "factors of organic evolution." All characters and attributes of species and groups have developed with changing conditions of life. The homologies among animals are the 
result of common descent. The differences are due to various influences, chief among these being competition in the struggle for existence between individuals and between species, whereby those best adapted to their surroundings live and reproduce their kind.

This theory is now the central axis of all biological investigation in all its branches, from ethics to histology, from anthropology to bacteriology. In the light of this theory every peculiarity of structure, every character or quality of individual or species, has a meaning and a cause. It is the work of the investigator to find this meaning as well as to record the fact. "One of the noblest lessons left to the world" by Darwin, Frank Cramer says, " is this, which to him amounted to a proEach fact has a meaning.

found, almost religious, conviction, that every fact in Nature, no matter how insignificant, every stripe of colour, every tint of flowers, the length of an orchid's nectary, unusual height in a plant, all the infinite variety of apparently insignificant things, is full of significance. For him it was an historical record, the revelation of a cause, the lurking place of a principle."

According to the theory of evolution every structure of to-day finds its meaning in some condition of the past. The inside of an animal tells what it really is, for it bears the record of heredity. The outside of an animal tells where its. ancestors have been, for it bears record of concessions to environment. Similarity in essential structure is known as homology. By the theory of evolution homology, wherever it is found, is proof of blood relationship.

The theory of organic evolution through natural law was first placed on a stable footing by the observations and inductions of Darwin. It has therefore been long known as Darwinism, although that term has been 
usually associated with the recognition of natural selection as the great motive power in organic change. Darwinism was at first regarded as a "working hypothesis." It is now an integral part of biological science, because all opposing hypotheses have long since ceased to work. It is as well attested as the theory of gravitation, and its elements are open to less doubt. All investigations in biology must assume it, as without it most such investigations would be impossible. Naturalists could no more go back to the old notion of special creation for each species and its organs than astronomers could go back to the old notion of guiding angels as directors of planetary motion. Without the theory of organic development through natural selection the biological science of to-day would be impossible.

In a third sense the word evolution is applied to a method of investigation. It is the study of present conditions in the light of the past. The Evolution as a method of study. preliminary work of science is the descriptive part. This involves accuracy of observation and precision of statement, but makes no great demands on the powers of logical analysis and synthesis. The easy work of science is largely already done. Those who would continue investigation must study not only facts and structures, but the laws that govern them. In the words of John Fiske, "Whether planets or mountains or molluscs or subjunctive modes or tribal confederacies be the things studied, the scholars who have studied them most fruitfully were those who have studied them as phases of development. Their work has directed the current of thought." The most difficult problems in life are susceptible of more or less perfect solution if approached by the method of evolution. They can not be even stated as problems in any other terms. In every science worthy of the name the 
history of origins and the study of developing forces must take a leading part.

In a fourth sense the word evolution has been applied to the philosophical conceptions to which the theory of evolution gives rise. PhiEvolution as a system of cosmic philosophy. losophy is not truth. When it is so it becomes science. At the best it points the way to truth. The broader the inductive basis of any system of philosophy, the greater its value as an intellectual help. The system of Herbert Spencer, the greatest exponent of the philosophy of evolution, is based wholly on the results of scientific investigation. It consists of a series of more or less broad and more or less probable deductions from the facts and laws already known. Systems like these which rest on scientific knowledge do not rise high above it. They can therefore be revised or rewritten as knowledge increases. They provide the means for their own correction. Systems resting on aphorisms or assumptions or definitions must disappear as knowledge increases.

Philosophy is never wholly identical with truth. The partial truth which it may contain becomes wholly error with the advance of science. The growth of exact knowledge transforms the truth in philosophy into science, leaving the absolute falsehood as the final residuum.

From this necessary fact comes the ultimate decay of all creeds or philosophic formulæ. Throughout the

Decay of formulæ. ages science and philosophy have been in conflict. Science is the same to all minds capable of grasping its conclusions. Philosophy changes with the point of view. It is the evanescent perspective in which the facts and phenomena of the universe are seen. This can never 
be the same under changing times and conditions. With the larger knowledge of to-morrow there will be large modifications in the accepted philosophy of evolution. Each succeeding generation will give to the applications of the laws of organic life a different philosophical expression.

In these four senses the word evolution is used with some degree of accuracy; but in the current literature What evolution of the day the word has many other is not.

meanings, some of them very far from any just basis. Some things which evolution is not we may here notice briefly.

Evolution is not a theory that "man is a developed monkey." The question of the immediate origin of man Man not a developed monkey.

is not the central or overshadowing question of evolution. This question offers no special difficulties in theory, although the materials for exact knowledge are in many directions incomplete. Homologies more perfect than those connecting man with the great group of monkeys could not exist. These imply the blood relationship of the human race with the great host of apes and monkeys. As to this there can be no shadow of a doubt, and, as similar homologies connect man with all members of the group of mammals, similar blood relationship must exist; and homologies less close but equally unmistakable connect all backboned animals one with another, and the lowest backboned types are closely joined to wormlike forms not usually classed as vertebrates.

It is perfectly true that in the higher or anthropoid apes the relations with man are extremely intimate ; but man is not simply " a developed ape." Apes and men have diverged from the same primitive stockapelike, manlike, but not exactly the one nor the other. 
No apes nor monkeys now extant could apparently have been ancestors of primitive man. None can ever "develop" into man. As man changes and diverges, race from race, so do they. The influence of effort, the influence of surroundings, the influence of the sifting process of natural selection, each acts upon them as it acts upon man.

The process of evolution is not progress, but better adaptation to conditions of life. As man becomes fitted

Not progress, but adaptation.

for social and civic life, so does the ape become fitted for life in the tree tops. The movement of monkeys is toward " simianity," not humanity. The movement of cat life is toward felinity, that of the dog races toward caninity. Each step in evolution upward or downward, whatever it may be, carries each species or type farther from the primitive stock. These steps are never retraced. For an ape to become a man he must go back to the simple characters of the simple common type from which both have sprung. These characters are shown in the ape baby and in the human embryo in its corresponding stages, for ancestral traits lost in the adult are evident in the young. This persistence comes through the operation of the great force of cell memory which we call heredity.

The evidence of biology points to the descent of all mammals, of all vertebrates, of all animals, of all organic beings, from a common stock. Of all the races of animals the anthropoid apes are nearest man. Their divergence from the same stock must be comparatively recent. Man is the nomadic, the apes are the arboreal, branch of the same great family.

Evolution does not teach that all or any living forms are tending toward humanity. It does not teach, as in Bishop Wilberforce's burlesque, "that every favourable 
variety of the turnip is tending to become man." It is not true that evolutionists expect to find, as Dr. Seelye has affirmed, "the growth of the highest Humanity not the goal of evolution.

alga into a zoöphyte, a phenomenon for which sharp eyes have sought, and which is not only natural but inevitable on the Darwinian hypothesis, and whose discovery would make the fame of any observer."

It is no wonder that a clear thinker should have rejected "the Darwinian hypothesis" when stated in such terms as this. The line of junction in evolution is always at the bottom. It is the lowest mammals which approach the lowest reptiles; it is the lower types of plants which approach the lower types of animals; it would be the lowest alga, to use Dr. Seelye's illustration, which would be transmutable into the lowest zoöphyte; it is the unspecialized, undifferentiated type from which branches diverge in different ways. Humanity is not the "goal of evolution," not even that of human evolution. There will be no second "creation of man" except from man's own loins. There will not be a second Anglo-Saxon race unless it has the old Anglo-Saxon blood in its veins.

Adaptation by divergence-for the most part by slow stages-is the movement of evolution. While occasional Change by slow divergence. leaps or sudden changes occur in the process, they are by no means the rule. In most cases of "saltatory evolution" the suddenness is in appearance only. It comes from our inability to trace the intermediate stages. When an epoch-making character is acquired, as the wings of a bird or the brain of man, the process of readjustment of other characters goes on with greatly increased rapidity. But this rapidity of evolution is along the same lines as the slower processes. Radical changes 
from generation to generation never occur. We do not expect to find birds arising from a "flying-fish in the air, whose scales are disparting into feathers." A flyingfish is no more of the nature of a bird than any other fish is. A cow will never give birth to a horse, nor a horse to a cow. The slow operation of existing causes is the central fact of organic evolution, as it is of the evolution of mountains and valleys. Seasons change as the relations which produce them change. But midsummer never gives way to midwinter in an instant. Nor does the child in an instant become a man, though in some periods of growth epoch-marking causes may make development more rapid. Life is conservative. The law of heredity is the expression of its conservatism. Life changes slowly, but it must constantly change, and all change is by necessity divergence.

There is in Nature no single "law of progress," nor is progress in any group a necessity regardless of conditions. That which we call progress No innate tend- rests simply on the survival of the better ency toward progression. adapted, their survival being accompanied by their reproduction. Those that live repeat themselves. The "innate tendency toward progression" of the early evolutionists is a philosophic myth. Progress and degeneration are alike the resultants of the various forces at work from generation to generation on and within a race or species. The same forces which bring progress to a group under one set of conditions will bring degradation under another. In their essence the factors of evolution are no more laws of progress than the attraction of gravitation is. Cosmic order comes from gravitation. Organic order comes from the factors of evolution. Evolution is simply orderly change.

Nor is evolution identical with the notion of sponta- 
neous generation. There is no necessary connection between the one theory and the other. Spontaneous generation, or birth without parentage, on the part of Spontaneous generation.

small or useless creatures was accepted in early times without question. As men began to observe these animals more carefully, the fact of their spontaneous generation was doubted. A great step was made when it was found that to screen meat from flies would protect it from maggots. A greater step came in our own time when it was proved that to screen infusions from air dust is to protect them from putrefaction or fermentation. Fermentation is "life without air." It is the decomposition of sugar by minute creatures who disintegrate it in their life processes. Putrefaction and decay are also the same in nature. There is literal truth in Carlyle's statement that there is still force in a fallen leaf, "else how could it rot?" It is the force of the minute organisms hidden in the leaf, and whose life is the leaf's decay. The decay and death of men from contagious diseases are known to be due to life processes of minute organisms, as is the gangrene which follows unskilful surgery. The study of the "fauna and flora" within living organisms has now become a science of itself, demanding the greatest care in observation and the most complete of appliances. "Omne vivum ex vizo," "all life from life," was an aphorism of the naturalists of a century or two ago. It was to them a new and broad generalization. It has not yet been set aside. The classic experiments of Tyndall show that this law applies to all creatures we have yet recognised or classified. As far as science can tell, spontaneous generation is still a myth, having no basis in observation, no warrant in experiment. It remains as a pure deduction from the philosophical conception of Monism. It is incapable of 
proof, insusceptible of refutation. The argument for.it is chiefly this : Life exists on a globe once lifeless. How did life begin? If not through spontaneous generation, how did it come? Must it not have been by the operation of those laws and forces which through all time change lifeless into living matter? Very likely, but we do not know. We know nothing whatever of such laws and forces, and we gain nothing by veiling our ignorance under a philosophical necessity.

Moreover, if spontaneous generation occurs as a resultant of any forces, like forces would produce it again. We have never known it to occur. Should it occur, the organisms thus produced would have no bonds of blood relationship with those already in existence. With these they should show no homology, as they could have no inheritance in common. But all known organisms have common homologies. The factors of organic evolution are essentially the same for all. The unity of life amid all its diversity seems to point to origin from a common stock. If not from one stock, the lines of division between one and another are hidden from us. The study of embryology breaks down the time-honoured branch lines of vertebrates, articulates, molluscs, and radiates. The groups of animals are more numerous, more complex, and more intertangled than Cuvier and Agassiz thought. The number of primary branches of animals or plants is uncertain, their boundaries undefined.

If spontaneous generation exists, it is a factor in evolution. If it is a factor, our explanation of the meaning and nature of homology must be fundamentally changed. But it may be that it should be changed. We can not show that spontaneous generation does not exist. All we know is that we have no means of recognising it. If there is now spontaneous generation of 
protoplasm, it can not take the form of any creature we know. An organism fresh from the mint of creation would be too small for us to see with any microscope. It would be too simple for us to trace by any instrumentality now in our possession. It could contain but a few molecules, and a molecule in a drop of water is as small as an orange beside the sun. Such a race of creatures, spontaneously generated, without concessions to environment, would grow hoary with the centuries before it came to our notice. Its descendants would have belonged for ages to the unnumbered hosts of microbes before we should be aware of its creation.

Evolution is not a creed or a body of doctrine to be believed on authority. There is no saving grace in being an evolutionist. There are many Evolution not a creed. who take this name and have no interest in finding out what it means or in making any application of its principles to the affairs of life. For one who cares not to master its ideas there is no power in the word. Evolution is not a panacea or a medicine to be applied to social or personal ills. It is simply an expression of the teaching of enlightened common sense as to the order of changes in life. If its principles are mastered a knowledge of evolution is an aid in the conduct of life, as knowledge of gravitation is essential in the building of machinery.

Ther 3 is nothing "occult" in the science of evolution. It is not the product of philosophic meditation or of speculative philosophy. It is based on hard facts, and with hard facts it must deal.

It seems to me that it is not true that "Evolution is a new religion, the religion of the future." There are many definitions of religion, but evolution does not fit any of them. It is no more a religion than gravitation is. One may imagine that some enthusiastic follower of 
Newton may, for the first time, have seen the majestic order of the solar system, may have felt how futile was the old notion of guiding angels, one for each planet to Evolution not a hold it up in space. He may have rereligion.

ceived his first clear vision of the simple relations of the planets, each forever falling toward the sun and toward one another, each one by the same force forever preserved from collision. Such a man might have exclaimed, "Great is gravitation; it is the new religion, the religion of the future!" In such manner, men trained in dead traditions, once brought to a clear insight of the noble simplicity and adequacy of the theory of evolution, may have exclaimed, "Great is evolution; it is the new religion, the religion of the future!"

But evolution is religion in the same sense that every truth of the physical universe must be religion. That which is true is the truest thing in the world, and the recognition of the infinite soundness at the heart of the universe is an inseparable part of any worthy religion.

But, whether religion or not, the truths of evolution must be their own witness. They can be neither

Science its own witness. strengthened nor controverted by any authority which may speak in the name of philosophy or of theology or of religion or of reason. "Roma locuta est ; causa finita est" is not a dictum which science can regard. Her causes are never finished. No power on earth can give beforehand the answer to her questions. Her only court of appeal is the experience of man. 


\section{THE ELEMENTS OF ORGANIC EVOLUTION.}

AlL the laws of life, whatever their nature, are valid throughout the organic world. They control the life processes of man, those of the lower animals, and those of "our brother organisms, the plants." They extend to each in its degree. The fact that the laws of heredity, for example, extend unchanged in essence from one extreme of organic life to another is most vital to our understanding of the nature of life. For such homology as this, for any fact of homology whatsoever, we have found but one cause, the influence of common descent.

There are many elements or factors which enter into the processes of organic evolution, and they stand in varied relations to one another. It is not possible to make a classification of them in which there shall not be inequality and overlapping of elements. For the purpose of our present discussion we may group these forces and factors under eight principal heads.

I. Heredity.-This is the "law of persistence in a series of organisms." Throughout Nature each creature tends to reproduce its own qualities and those of its ancestors. "Like begets like." Creatures resemble their ancestors. The germ cell specialized for purposes of reproduction is capable in its development "of repeating the whole with the precision of a work of art." Heredity is the great conservative force of evolution. 
Its influence is shown in the persistence of type, in the existence of broad homologies among living forms, in the possibility of natural systems of classification in any group, in the retention of vestigial organs, in the early development and subsequent obliteration of outworn structures once useful to the race or type.

The physical basis of heredity has been in recent years the subject of many elaborate investigations. The complete homology of the germ cell with the one-celled animals, or protozoa, is now generally recognised, and there is large reason to believe that in the bands and loops of the nucleus of the germ cell is found the visible vehicle by which hereditary tendencies are transmitted.

II. Irritability.-All living beings are affected by their environment. Living matter must always respond in some degree to every external stimulus. All living beings are moved by or react from every phase of their surroundings. The nervous system and its associated sense organs are directly related to the conditions of life. They are concessions made to the environment. The power of motion, whatever it may be, requires the guidance obtained from the impressions made by external things. In all animals this knowledge, whatever its degree of completeness, tends to work itself out in action. In plants the same thing is in some degree true. The essential difference is that, having no power of locomotion, the plant is without a general sensorium. The parts that move-growing rootlets, tips of branches, and the like-have sensibility and power of motion in the same series of cells. The animal, a colony of cells which move as a whole, has a specialized nervous system which guides the whole.

As a rule, the environment does not act directly on the individual. Its influence is felt chiefly in modifying its action, in increasing, diminishing, or changing its 
efforts. The effects of environment are practically recognised in processes of education, of agriculture, the care and nurture of men and of horses and trees and wheat. Evil surroundings produce evil effects. Easy surroundings, reducing the stimulus to effort, tend to produce organic degeneration. In larger ways response to environment produces a long series of "concessions." A character or condition in itself of the nature of a response to outside stimulus may be called a concession. Among such concessions are the skin, the eyes, the brain, the sense of pain, in fact, in the ultimate analysis, every organ and every function of the body. For without environment all these would be unnecessary. Their existence would be inconceivable.

The fitness by which organisms have been perpetuated is simply obedience or adaptation. Those which survive are fitted to the conditions of life. In other words, they are obedient to these conditions. Hence we may define the process as one of the survival of the obedient. The force which commands obedience is that of the environment, and the obedience demanded is that of such a reaction or relation to this environment as will not obstruct the processes of life.

Every form or phase of obedience shows itself as adaptation. Every adaptation is a concession to the Concessions of life. actual environment on the one hand, to the laws of life on the other. The function of the eye, for example, is to give information as to the nature of objects more or less remote from the organism. The purpose of giving this knowledge is to enable the organism to act upon it. To be able to act demands that the action must be safe. If the creature could not act, it would have no need for such knowledge. If its acts were not in accord with knowledge, the knowledge would be useless. If. there 
were no break in the uniformity of the environment, there would be no need of such knowledge. If there were no variation in lights and shadows, the eye would be powerless to bring information. The senses deal with changes or breaks in reality rather than with realities themselves. Because, in action, the organism must be obedient to the demands of its environment, it is the function of the eye to make known these demands. The existence of the eye is therefore a concession to the environment. A concession of like nature is the brain itself, of which the eye and the sense organs in general may be considered as prolongations. These appendages of the brain carry to it truth of varying kind or degree. This truth as to external nature furnishes the basis of that obedience which in the animal expresses itself in action.

The respiratory apparatus is an adaptation for the purpose of purifying the blood from the waste produced in the processes of life. It is a concession on the one hand to the demands of life in cell and tissue, and on the other hand to the nature of the surrounding medium. A change in the atmosphere would demand a corresponding change in the organs of breathing. If such a concession were impossible, the species in question would become extinct, as its individuals would perish. If the concessions necessary to continued existence should involve changes in other organs, the process of the survival of the obedient would in time produce these changes.

If there were no surrounding medium there would be no organ of respiration. If there were no light there would be no organ of vision. If there were no sound there would be no ear. If there were no motion there would be no need for knowledge, and therefore no sensation. If there were no power of locomotion there 
would be no sensorium. If there were no environment there would be no concessions to it. Without concession there would be no specialization of functions or organs. Without variation in environment there could be no choice in action. The concessions to the environment constitute, therefore, practically the whole structure of any animal and the whole of the functions of its life. It is in the response to environment, the concession, the adaptation, the specialization, that the progress of life consists. It is in characters thus produced that man and the higher animals differ from the protozoa. Even the protozoan has its concessions. The phenomenon of growth causes the substance of the one-celled animal to increase faster than its absorptive power. The waste of the body varies as the substance-that is, as the cube of the diameter of the creature. The absorptive power of its surface must increase as the square of the diameter -that is, as the surface. Hence, a one-celled animal passing a given small size must either starve to death or else make some concession to its surroundings. This concession is reproduction-the one-celled creature must split into two animals. This increases the digestive power, with no increase of substance. Even the presence of skin on a protozoan is a concession to its surroundings. That a given protozoan is developed with an outside covering shows that natural selection has been long at work on its ancestry in preparing such a concession to external demands.

A creature which had known no environment and which had inherited no concession would be formless and structureless. It could be little if anything more than an organic molecule, or at the most a nebulous mist of organic molecules without parts or form or function. We know no such nebulous life as this. All the animals and plants on the records of science show traces of 
a long ancestral history. Their bodies are full of concessions to environment, and their functions are all in the line of obedience to those conditions in life in which their ancestors have been thrown.

We recognise that man is the highest in structure among living beings. This fact implies that in his physical structure are the greatest concessions to environment. In his functions the most perfect obedience is made possible. His power of choice among competing lines of action but emphasizes the need of choosing the best action. The best action is the safe action-safe for the individual, safe for the species, for only those races survive who care for their young as they care for themselves.

The greatness of the human intellect depends on the progressive concessions to environment by which the human brain through the ages has been gradually built up.

III. Individuality.-No two organisms are exactly alike. There is in each individual of whatever species "a divine initiative" which prevents it from being the slavish copy of any which have gone before. The "survival of the fittest " rests on the existence of different degrees and kinds of fitness. This it is the part of the laws of variation to produce. Every step in divergence or specialization gives room for more life. The abundance of life is dependent upon its variety. Thus the world is never full, for there is always room for organisms better or differently adapted to each set of its varied conditions. The arrangement of double parentage tends to promote variety in life. Each new individual has all the ancestors of its father as well as all those of its mother, and with each one these are brought into new combinations. The process of amphimixis, the mingling of the hereditary characters of the two germ 
cells, male and female, to form a new fertilized cell, has as its essential function the promotion of variation. The processes of karyokinesis, the subdivision of the nuclear material in the formation of a new cell, tend in the same direction. By the result of the subdivisions incident in forming the sperm cell or the ovum, no one of these is left exactly like any other. From this point of view we say that variation is, as Professor Osborn has pointed out, "in reality a phase of heredity." The same structures that provide for the continuance of the species prevent the actual repetition of the individual.

Besides these sources of germinal variation there are the forces or laws which produce acceleration or retardation in growth. Much of the advance in power or specialization among organisms comes from the saving of time in the process of development. As growth goes on, the forms we call lower pass slowly through the various stages of life. Their development is finished before any high degree of specialization is reached. The embryo of the higher form passes through the same course, but with a rapidity in some degree proportioned to its future possibility. Less time is spent on nonessentials, and we may say that by the saving of time and force it is enabled to push on to higher development.

The gill structures of the fish by which its blood is purified by contact with air dissolved in water last its whole lifetime. The fish never outgrows this structure and never acquires the function of breathing atmospheric air. The frog is fish-like for a period in its life, but the development is accelerated, organs for breathing atmospheric air are produced, and the gills become atrophied and disappear from view. Their traces remain, for by the law of heredity no creature can ever wholly let go of its past. That its ancestors once breathed in water 
can never be forgotten. With bird or mammal the acceleration is still more marked, and the gill structure has passed into atrophy before the egg is hatched or the animal born. The force of acceleration hurries the embryo along through these temporary stages, and with this shortening of useless steps comes the possibility of higher development.

Conversely retarded development brings about degeneration, while variations in any direction with species or organs has the larger purpose of increasing variety, of promoting individuality.

Similar results are brought about by variations in use or in effort. The organ which is used thrives, while the unused organ disappears with its function. These changes affect the individual vitally and directly. Whether they are transmitted from generation to generation in any degree is still unknown. Characters resulting from the use, effort, or experience of the individual are known as acquired characters. Such acquired characters are the strong arm of the blacksmith, the skilled hand of the artist, the trained ear of the musician. These characters are not subject to inheritance by the laws of heredity in the same way or in the same degree that inborn characters are. Nevertheless, it is claimed by a large number of evolutionists, the so-called Neo-Lamarckian school, that there is a law of the transmission of acquired characters. Such a law was formulated by Lamarck as his fourth law of evolution in these words :

"All that has been acquired, begun, or changed in the structure of individuals in their lifetime is preserved in reproduction and transmitted to the new individuals which spring from those who have inherited the change."

In the words of Herbert Spencer, the leader of the 
Neo-Lamarckians, “ Change of function produces changes of structure; it is a tenable hypothesis that changes of structure so produced are inheritable."

The transmission of acquired characters is still one of the hypothetical factors of evolution, but we may here give it only this passing reference. Among the remaining factors which promote variety in life must be reckoned variation in environment. No two organisms can have exactly the same surroundings, and the surroundings modify development. With this goes the destruction of the unadapted, the various phases of the great sifting process known collectively as natural selection. The "survival of the fittest" must rest on the existence of the fittest. The "origin of the fittest" involves a series of difficult problems, some of them still unsolved.

IV. Natural Selection.-The great motive power of organic evolution is the force or process of natural selection. In the conditions of life those organisms last longest which are best fitted to these conditions. The term "natural selection" originated from the use of the word "selection" by breeders of animals to indicate the process of "weeding out" by which they improve their breeds. For the method by which in Nature a new species is brought into existence seems to be precisely parallel to that by which we may artificially produce a new breed of cows or of dogs, a new race of pigeons, or a new variety of roses.

Throughout all Nature the number of organisms brought into life is far in excess of the number of those which can come to maturity. All live that can live, and in general those that can not live are those whose individual variations are least favourable. Only a small minority of the whole reach their full growth. The destruction of the others, to use Bergen's words, is 
"not indiscriminate, but it will first and mainly comprise those individuals least able to resist attack."

This is the essential fact upon which rests Herbert Spencer's law of "the survival of the fittest." At the same time the survival of the fittest does not tell the whole story of natural selection. But a small part of the actual characters of animals and plants can be traced directly and solely to the principle of utility. The survival of the existing likewise is a large element in the great process of natural selection. Thus, a water bird has webbed feet. The webbing is useful in swimming. Its presence is due to its utility. The survival of the fittest in water birds may mean the survival of the best swimmer, and the best swimmer is the one with the most useful webbing. But a character quite as persistent may be a perfectly useless one, as a special arrangement of the plates on the tarsus, or the flattening of a single claw. This may have in itself no utility at all. Its presence may not be due to the survival of the fittest. It persists because such a character was possessed by some ancestor. It has been retained through heredity. The nails must have some form, the plates some arrangement, the wing coverts some colour. This ancestral form or colour is as good as some other would be. Hence comes its persistence, which is simply a survival of the existing, no question of relative fitness being involved.

From the "survival of the existing" arises the persistence of those forms which actually inhabit a given district whether they be ideally the fittest or not. By such means the faunæ of isolated regions are perpetuated, the barriers of land or sea or climate excluding them from competition with the "fitter" organisms that may inhabit other regions. "Possession is nine points of the law" of organic survival, as it is said to be else- 
where. Possession and not abstract fitness has determined the nature of the island faunæ, lake faunæ, and isolated faunæ and floræ generally. This is shown by the rapidity by which the species composing these become extinct when brought into competition with the more persistent forms which the continent has developed.

But as all this represents a natural adjustment produced by natural relations as distinguished from artificial selection produced by the act of man, we may still include it under the head of natural selection. Whatever result is brought about in the struggle for existence by the action of natural forces without human aid is natural selection in the sense in which Darwin used the term.

The term "fitness" as used in these discussions means, of course, only the power to win in the peculiar kind of contest that may be in question, no moral element and no element of general progress being necessarily involved.

In the question of fitness or unfitness the question of goodness or badness is only incidentally concerned. To be fit, in the biological sense, is not necessarily to be good, except as in the long run altruism promotes individual power and strength.

The struggle for existence appears under a threefold form: the struggle of creatures with like creatures, the struggle with unlike forms, and the struggle with the conditions of environment. In general, when the environment is most favourable, the competition of individual with individual will be most severe. Where this environment is alike favourable for many different forms or species, the struggle between species and species becomes intensified. Where conditions are adverse, the number of forms able to maintain themselves will be smaller, but those which acquire adaptation, not 
being crowded by competing forms, often exist in countless numbers.

The distribution of fishes may illustrate this. The most favourable condition for fish life is found about coral reefs, in the clear, equable waters of the tropics. Here many forms find favourable conditions, but the competition among their individuals is severe. In arctic waters but few species appear; the most are excluded by the temperature itself. But these few forms are represented each by myriads of individuals. Only a few kinds can enter into competition. The struggle is not that of species against species; it is the survival of those that can react from the environment, that can maintain themselves against the hard conditions of life. But these conditions are not hard to these individuals who survive. The arctic life is the life they are fitted for. The struggle for existence is not felt as a stress or strain by the adapted.

Hence comes the fact noticed by Darwin, that, while all intelligent men admit the struggle for existence, very few realize it. Men in general are fitted to the struggle endured by their ancestors, as they are fitted to the pressure of the air. They do not realize the pressure itself, but only its fluctuations. Hence it comes that many writers have supposed that the struggle for existence belonged only to animals and that man is or should be exempt from it. Competition has been identified with injustice, fraud, or trickery, and it has been supposed that some act of legislation would put an end to it forever. But competition is inseparable from life. The struggle for existence may be hidden in social conventions, but it can never be extinguished. Nor should it be, for it is the essential force in the progress of life.

Malthus's law of population, often quoted, is in substance this: Man tends to increase by a geometrical 
ratio-that is, by multiplication. The increase of food supply is by arithmetical ratio-that is, by addition; hence, whatever may be the ratio of increase, a geometrical progression will sooner or later outrun an arithmetical one. Hence, sooner or later the world must be overstocked, did not vice, misery, or prudence come in as checks, reducing the ratio of multiplication. This law has been criticised as a partial truth, so far as man is concerned. This means simply that there are factors also in evolution other than those recognised by Malthus. Nevertheless, Malthus's law is a sound statement of one great factor. And this law is simply the expression of the struggle for existence as it appears among men.

In a world limited in extent and in possibilities, any rate of increase among organisms must bring about a struggle for existence. The ratio of increase is a matter of minor importance, for each species would fill up the whole world at last. It is the ratio of actual net increase above loss which determines the fate of a species. Those increase and maintain themselves in which the death rate does not exceed the rate of increase. Those who live "beyond their means" must sooner or later perish.

Thus it comes about through natural selection that there is everywhere seemingly perfect adaptation, the " fitting of the dough to the pan," of the river to its bed. But this fitting is never wholly perfect, for still more complete adaptation may come; and as conditions change adaptations must change also. Progress follows organic dissatisfaction. Where there is no reason for change there is no progress; degeneration may set in, and degeneration of one sort or another follows withdrawal from the current of the struggle for existence. "Whatever is desirable," says Weismann, "becomes necessary 
as soon as it is possible." Whatever is not needed tends to decline and disappear.

In our discussion of social evolution we need sometimes to remember that the very perfection of society must always appear as imperfection; for a highly developed society is dynamic. It is moving on. A static society, no matter how perfect it may seem, whether a Utopia, Icaria, or City of the Sun, is in a condition of arrested development. Its growth has ceased, and its perfection is that of death. The most highly advanced social conditions are the most unstable. The individual man counts for most under those conditions; for the growth of the individual man is the only justification for the institutions of which he forms part. The most highly developed organism shows the greatest imperfections. The most perfect adaptation to conditions needs readaptation, as conditions themselves speedily change. The dream of a static millennium, when struggle and change shall be over, when all shall be secure and happy, finds no warrant in our knowledge of man and the world. Self-realization in life is only possible when self-perdition is also possible. When cruelty and hate are excluded by force, charity and helpfulness will go with them. Strength and virtue have their roots within man, not without. They may be checked but they can not be greatly stimulated by institutions and statutes.

In this connection we have also to remember that the struggle for existence in human society does not mean brutality. It is not necessarily a war to the knife, nor a struggle with fists nor with balances of trade. The elements of ultimate success in the struggle are not teeth, nor claws, nor brute strength, nor trickery. Through all the ages love has been stronger than force; and those creatures who could help each other have been stronger than those who could only fight. 
By good or right in human development we mean simply the opportunity for more life or higher life. That is good which makes me strong and gives strength to my neighbours. Might does not make right, but whatever is right will justify itself in persistence, and persistence is strength. That which is weak dies. We only know God's purposes by what he permits. That which persists and grows must be in line with such purposes. A law is only an observed generalization of what is. There is no law which reads, "This and this ought to be, but is not."

V. Self-activity.-Another factor in evolution is furnished by the functional activity of the individual. Nature is a thrifty investor. She withdraws all unused capital. The old parable of the talents, wherein the owner of the unused talent lost all that he had, describes the workings of Nature. The unused organ loses its power and dwindles away. What comes out of a man determines his character. What he has done in the past furnishes the law of his future. The essence of individual character building, with the lower animals as with man, lies in action. Whatever he is he must make of himself. Heredity only furnishes the tools, and the environment is the leverage. Nor is this great law confined to animals alone. Even with plants the function must justify the organ. The branch which does not carry sap withers and dies. The fruit which does not ripen is cast to the ground. In a sense, too, the function must precede the organ. Where something is to be done, there will arise a special method of doing it, and the organ which supplies this better method will survive in natural selection.

Among the higher animals functional activity is the basis of individual happiness. There is no permanent feeling of joy except through functional activity. Dis- 
sipation, stimulation, tricks on the nervous system of any sort whatever give only a counterfeit happiness. Subjective joys are followed by subjective misery. There is "no pleasure in them." "The very fiends weave ropes of sand rather than taste pure hell in idleness."

There is a wild joy in "Nature red in tooth and claw" that is not found in static life. And while higher development brings higher pleasures, these bear the same relation to self-activity. The pressure of environment gives only pain in itself. Ennui is chronic pain, Nature's warning against the dry rot of functional inactivity. To enjoy life, man or animal must be doing, working, thinking, fighting, loving, helping-something positive. And no thought or feeling of the mind is complete till it has somehow wrought itself into action.

VI. Altruism.-Another of the great forces in organic development is mutual help, or altruism. Where organisms come into any sort of relation one with another, there must be some conditions more favourable than others. The law of altruism is the expression of the best relation of one organism to another of its own kind or type. The words good, better, are expressive of human affairs. They are subjective terms, referring to the welfare of the individual. In the general sense, that is good which makes more or higher life possible. That is good in Nature which "gives life more abundantly." It is good to "make two blades of grass grow where only one grew before." It is good also to make possible the growth of a specialized and highly adapted form, where only creatures of a lowly organization had existed before. Altruism is the expression of the permanence of mutual respect and mutual forbearance. The rule we call golden is the expression of strength as well as of right. It is not true that "might is right" 
in the narrow sense in which that phase is commonly used; but it is true that what is right will justify itself sooner or later by becoming might. Cruelty, vice, and selfishness are wrong as the expression of weakness, of low vitality, of conditions which make abundance of life impossible.

Altruism is in no sense confined to man. There is no part of the animal kingdom in which it is unknown, no part of the vegetable kingdom without its traces. Favourable interrelations are possible wherever life is. The expression of such relations is altruism.

It can be shown that social virtues are powerful aids to survival in the struggle for existence. The race is not " to the swift" nor "the battle to the strong," but "to them who can keep together." The care of the young is a far more effective agency in the survival of the species than iron muscles or huge jaws. The willingness to die for the young is a guarantee that the young may live.

"More ancient than competition," says Oscar McCulloch, "is combination. The little, feeble, fluttering folk of God, like the spinning insects, the little mice in the meadow, the rat in the cellar, the crane on the marshes, or the booming bittern-all these have learned that God's greatest word is together and not alone. He who is striving to make God's blessing and bounty possible to most is stepping into line with Nature. The selfish man is the isolated man."

Altruism is a robust sentiment set deep in the breast of organic life, and not in danger of extinction. It is as old as selfishness and as hard to eradicate. It no more needs coddling than hunger does. It depends on no external sanction, for the creatures without altruism pass away, leaving no descendants. There is a bounty on their heads, whether they be wolves or hawks or men. 
Altruism expresses itself in all that make the human life sane, joyous, effective. Science is herself a consummate result of the altruism of the ages, whereby no man's experiences belong to himself alone, but become part of the heritage of those who follow him. Human institutions have grown out of the social instinct. They are the fossils of past altruism. All forms of art, literature, music, religion, arise and are developed through mutual help. And while the relations of altruism tend to limit the freedom of the individual, it is only through such limitations that the individual can develop in security or in realfreedom.

In the very beginnings of life appear the beginnings of altruism. Among the one-celled animals or pro-

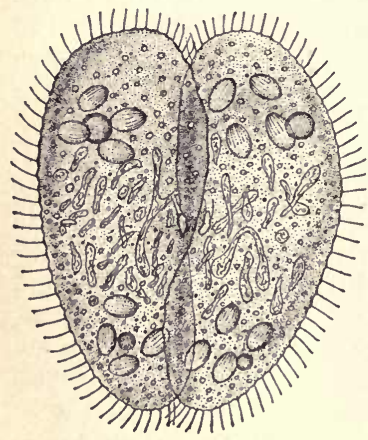

Fig. 4.-Conjugation of infusoria. tozoa is seen the relation of mutual help. In the conjugation of cells among these creatures appear the beginnings of the gigantic fact of sex. By this process two minute onecelled creatures come together, and part of the hereditary substance of the one is exchanged for that of the other. After this exchange neither the one nor the other is exactly what it was before. The results of this change are propagated in the descendants of each. The ultimate purpose of the exchange is to produce and promote variety in life. That is the ultimate purpose of the whole sex relation. From the beginning to the end it is essentially altruistic. 
It never becomes selfish except in its perversion. Its perversion is its destruction. And from the simple altruistic beginnings of the conjugation of cells in those simple organisms arise with evolution all the complex possibilities of love, conjugal, filial, and parental.

In another way the altruistic tendencies are shown in the aggregation of cells. Among animals of one cell the ordinary processes of division give rise to a new organism for each division. But if the new cells formed by such subdivision still remain attached to each other, a complex organism is built up. It is thus that the single germ cell in the higher animals grows into the embryo, and the embryo through the stages of infancy and youth into the adult organism.

The co-operation of the members of the colony of cells of which the compound animal is composed makes possible all the various forms of organic differentiation. A single cell is a unit, complete in itself and independent. All the functions possible to it are united in a single structure. With a complex organism the different cells are gathered into groups to form tissues. Out of these tissues different organs are built up, and each different organ performs a distinct function. In the compound structure of man a multitude of cells are joined to perform the work of assimilation, and a host of others purify the blood; to another multitude is assigned the task of locomotion. Still others, of finer texture, receive impressions of external things and transmit these impressions into the phenomena of motion. Specialization, differentiation, organization, and the exquisite functions of nerve tissue, are all resultants of the altruistic co-operation of cells. As individual men under altruistic impulses unite together to form societies and states, so are individual cells gathered together to form the human body. The conjugation of cells is a method 
by which life is continued and renewed in an endless chain which death has never broken. The aggregation of cells gives rise to all that makes life effective. But the division of labour and specialization of parts brings death to the individual. Sooner or later the correlation of parts must be broken and the outworn individual must give place to one freshly formed.

The gains through altruism as a factor in evolution can not be overstated. Love and kindness, specialization and adaptation, instinct and intelligence-all these belong to its biological results. In human society mutual help has given science, which is the garnered wisdom of society. It has given art, education, religion. All these are in one way or another related to the good or pleasure of others. From altruism institutions arise, and institutions bring security and effectiveness.

To all this there is, of necessity, another side. All the gifts of the gods have some drawback connected with them. This is the so-called law of compensation. Mutual help leads to mutual dependence. Combination destroys absolute freedom in making freedom worth having. Alliances degrade as well as help, for the needs and functions of the individual are lost in those of the alliance. The single cell is self-sufficient, independent, and, until altruisic relations come in, immortal. As Weismann has shown, the subdivision of the single cell, by which it divides into two similar cells, is not homologous with death. Death is a necessary attribute of compound animals only. It is the price paid for specialization. If it be true, as is claimed, that the cells prevented from conjugation ultimately die a natural death, still this death is a price paid for altruism. It did not exist before combination became possible.

In like fashion the growth of society has abridged the freedom of the individual man in making that free- 
dom worth having. Mutual help in society has brought about mutual dependence. It has at the same time brought a security and strength which must be forever impossible under purely individualistic conditions. The tendency for organisms to join together for mutual aid is therefore one of the primal tendencies of life. It is involved in the very definition of life itself. It can never become outworn or exhausted. It must in greater and greater degree rule the hearts of men, as men become wiser, purer, stronger in the progress of evolution. "In the very nature of things God has made this law of mutual aid so strong that he has impressed and stamped it on the life of everything that breathes."

As the cell is related to the tissue, so is the individual man connected with society. The essential difference is the obvious one that the individual man moves, lives, and dies as an individual, while the individual cell is confined to its place by physical limitations.

In recognising the fact that the parallelism exists, it is not necessary to push it too far. From the aggregation of cells results specialization of parts, division of labour among organs, progress, and adaptation; and ultimately from the same source springs the necessity for organic death. Being bound together by physical bonds, the wearing out of one organ means the decay of the whole. In like manner, from the altruism of the individual results the strength of the state, the division of labour among men, and the consequent increase of effectiveness, the progress of knowledge, and the amenities of life. We do not need to say that a society or a nation must die for like reasons, for its units are bound not by physical bonds, but by invisible forces, and the wearing out of one organ could not necessarily destroy the whole. But the complex animal and the complex society are alike manifestations of the law of altruism. 
And, as Dr. Amos Griswold Warner has wisely observed, no species and "no race ever became extinct through an excess of brotherly love."

VII. Isolation.-A great factor in the production of variant forms is the isolation of groups of individuals from the mass of their species. The barriers of the earth, separating one group of individuals from other individuals of the same kind, cause them to be exposed to different influences. The reaction from environment is different in one case from another. As a result, the presence of barriers shows itself in specific variation.

Each species of animal or plant tends to extend and to cover the world. That a given species has not occupied any certain area is due to one of three causes: either $(a)$ the species has never entered the district; or (b), having entered it, it could not maintain itself ; or (c), having maintained itself the changed conditions have made of it another species.

Thus we may say that the reason why the civet cat is not found in New England is because it has never been able to reach that district in its movements. The skylark, which has been brought there, has not maintained itself because, in the individual cases at least, it could not; while the European rabbit, introduced years ago into Porto Santo in the Madeiras, does not exist because its descendants are so much altered that we can not recognise them as the same species.

With one of these three general propositions, selfevident, no doubt, all the facts of geographical distribution may be ccnnected. Each species extends its range wherever it can, maintains itself if it can, and undergoes change wherever its members are brought into new conditions or separated by barriers from the mass of their kind.

The characters to be attributed directly to isolation 
are for the most part those of minor importance, the superficial traits of the species rather than the deepseated qualities of the group. But these are none the less real, and to this series of influences much of the variety of the life of the globe must be attributed.

The survival of the existing, which is the basis of most of the distinctions between one species and another, Survival of the existing.

is not less real than the survival of the fittest. In making up the fauna or flora of any region, those creatures actually present must leave their qualities as an inheritance. If they can not maintain themselves, their type passes away as unfit. If they maintain themselves in isolation, their characters become persistent as those of the new species.

Still other factors in organic evolution may be more or less clearly defined, either in connection with those above mentioned or as fundamentally distinct.

One of these is the following: The transmission of characters of the parent as distinct from proper heredNutrition in transmission. ity. A starved hill of corn means illnourished grains. The plants produced from ill-nourished seeds may be stunted by lack of vitality or lack of starch without any change or deficiency in the germ itself. In like manner feeble children may owe their traits to the temporary illnesses of a strong mother. A sound mind demands a sound body, and a sound body is necessary to well-nourished offspring. With the characters of the germ cell these conditions have nothing to do, and their homologue is found in such defects as insufficiency of milk.

VIII. Inheritance of Acquired Characters.-The inheritance of acquired characters mentioned above, a process of transmission possibly different from germ heredity, has been lately the subject of much discussion. 
To this the present writer does not care to add. According to some writers, as Herbert Spencer, this inheritance is a prominent factor in evolution itself. According to August Weismann, it is simply a myth invented to explain phenomena the causes of which are unknown. Most of the arguments on both sides, thus far, have been theoretical only, based on no inductive evidence, and in science arguments of this sort are without value. Both suppositions rest, as Prof. Henry Fairfield Osborn has said, less " in fact than the logical improbabilities of other theories." "Certainly," Professor Osborn goes on to say, "we shall not assist research with any evolution factor grounded upon logic rather than upon inductive demonstration. A retrograde chapter in the history of science would open if we should do so, and should accept, as established, laws which rest so largely upon negative reasoning. Darwin's survival of the fittest we may alone regard as absolutely demonstated as a real factor without committing ourselves as to the oriThe unknown gin of fitness. The (next) step is to factors. factor or factors which will cause quite as great a surprise as Darwin's. The feeling that there is such first came to the writer in 1890 , in considering the want of an explanation for the definite and apparently purposeful character of certain variations. Since then a similar feeling has been voiced by Romanes and others, and quite lately by Scott, but the most extreme expression of it has recently come from Dr. Driesch in the implication that there is a factor not unknown but unknowable! ... We are far from finally testing or dismissing these old factors, but the reaction from speculation upon them is itself a silent admission that we must reach out for some unknown quantity. If such does exist there is little hope that we shall discover it except 
by the most laborious research; and while we may predict that conclusive evidence of its existence will be found in morphology, it is safe to add that the fortunate discoverer will be a physiologist.

"Chief among the unknown factors are the relations between the various stages of development and the environment."

Professor Osborn concludes this discussion with the belief that "progressive inheritance is rather a process of substitution of certain characters and potentialities than the actual elimination implied by Weismann. "My last word is," he says, "that we are entering the threshold of the evolution problem instead of standing within the portals. The harder tasks lie before us, not behind us, and their solution will carry us well into the twentieth century." 


\section{IV.}

THE FACTORS OF ORGANIC EVOLUTION FROM THE STANDPOINT OF EMBRYOLOGY.

By Prof. Edwin Grant Conklin.

OUR knowledge of the mechanics of evolution must always depend in large part upon the study of indiEmbryology shows the method of evolution. vidual development. More than any other science, embryology holds the keys to the method of evolution. If ontogeny (life history of the individual) is not a true recapitulation it is at least a true type of evolution, and the study of the causes of development will go far to determine the factors of phylogeny or race development.

The causes and methods of evolution are intimately bound up with those general phenomena of life, such as assimilation, growth, differentiation, metabolism, inheritance, and variation; and the evolution problem can never be solved except through a study of these general phenomena of life itself. Our great need at present is not to know more of the course of evolution, but to discover, if possible, the causes of growth, differentiation, repetition, and variation. All these general phenomena are most beautifully illustrated in the development of individual organisms, and because they are fundamental to any theory of evolution I shall dwell upon them 
rather than upon the evidences for the Lamarckian or the Darwinian factors.

I call attention very briefly to the following propositions : I. Development, and consequently evolution, is

Statement of propositions. the result of the interaction of extrinsic and intrinsic causes. 2. Intrinsic causes are dependent upon protoplasmic structure. 3. Inherited characters must be predetermined in the structure of the germinal protoplasm. 4. Germinal, as compared with somatic, ${ }^{*}$ protoplasm is relatively stable and continuous, but not absolutely so, as maintained by Weismann; therefore, extrinsic causes may modify both germinal and somatic protoplasm. 5. It is extremely difficult to determine whether or not extrinsic factors have modified the structure of the germinal protoplasm. This is illustrated by some of the evidences advanced for the inherited effects of diminished nutrition, changes in environment, use and disuse. 6. Experiment alone can furnish the crucial tests of these Lamarckian factors.

I. The causes of development in general are usually recognised as twofold-extrinsic and intrinsic. As ex-

Causes of development. amples of extrinsic causes may be mentioned gravity, surface tension, light, heat, moisture, and chemism in general; examples of intrinsic causes are the non-exosmosis of salts from living bodies in water, the pouring of a glandular secretion or the sap of plants into a cavity under high pressure, the active changes in shape and position on the part of cells, assimilation, growth, division, etc. There is not, however, a uniformly sharp and distinct line of demarcation between these two factors of develop-

* Somatic cells are those composing the tissues of the body as distinguished from germ cells-those destined to form the new organism. 
ment. Phenomena once supposed to be due entirely to intrinsic causes are now known to be the result of extrinsic ones, and it is practically certain that this will be found true of still other phenomena. But although it is not possible to draw any hard and fast line between these two classes of causes, one can, in general, recognise a very marked difference between them. Extrinsic causes may, in large part, supply the stimulus and the energy for development, and may more or less modify its course ; the intrinsic causes are of a much more complex character than the extrinsic ones, they are inherent in the living matter and in large part predetermine the course of development. In one form or another the distinction between these two classes of causes is recognised by all naturalists. Professor His calls the intrinsic causes "the law of growth," the extrinsic ones the conditions under which that law operates. These designations correspond, at least in part, to Professor Cope's anagenesis and katagenesis, and to Roux's "simple and complex components" of developmental processes.

While it is necessary to emphasize the differences between these two classes of causes, it is not intended thereby to dogmatically assert their total difference in kind. It may well be that these extrinsic and intrinsic causes are totally different in kind, but in our present state of ignorance it would be ur.justifiable to affirm it. On the other hand, it would be just as unwarrantable to dogmatically affirm that there is no difference in kind between these two classes of causes, and that, therefore, all vital phenomena are only the manifestations of heat, light, electricity, attraction, repulsion, chemism, and the like. It may be that this is true, but there is as yet no sufficient evidence for it, and to attempt, as certain dynamical and mechanical hypotheses do, to refer all vital phenomena directly to such simple components as 
those named above is practically to make impossible at present any explanation of vital phenomena. "If we would advance without interruption," says Roux, " we must be content, for many years to come, with an analysis into complex components."

2. We need not now further concern ourselves with an explanation of extrinsic causes or simple components, since this subject properly belongs to

Intrinsic causes arise from nature of protoplasm. chemistry and physics. If, however, we examine more closely some of the intrinsic causes or complex components, we will find that they are always associated with more or less complex structures; in fact, they are dependent upon structure.

The smallest and simplest mass of protoplasm that can manifest all the fundamental phenomena of life, such as assimilation, growth, division, and metabolism, is an entire cell, nucleus and cytoplasm, and probably centrosome. The cell is composed, as microscopic study plainly reveals, of many dissimilar but perfectly coadapted parts, each performing its specific function, and it may therefore properly be called an organism. Some phenomena of cell life may be directly referred to the various visible constituents of the cell, but many of them are evidently connected with structures which we can not see, structures which may perhaps never be seen, and yet which must be vastly more complex than the most complex molecules known to chemistry, and yet much more simple than the microsomes, centrosomes, and chromosomes which are visible in the cell. With these ultra-microscopical particles many of the most fundamental phenomena of life are associatedviz., assimilation, growth, metabolism, and probably

* Wilhelm.Roux. Einleitung : Archiv für Entwickelungsmechanik der Organism. 
differentiation, repetition, and variation. These functions are so co-ordinated that there can be no question that the ultra-microscopical structure is an organization, with part coadapted to part. The organization of the cell, therefore, does not stop with what the microscope reveals, but must be supposed to extend to the smallest ultimate particles of living matter which manifest specific functions. These are the vital units so generally postulated, the "smallest parts" of living matter, as they were called by Brücke, who first demonstrated that they must exist; the "physiological units" of Spencer, the "gemmules" of Darwin, the "micella groups" of Nägeli, the "pangenes" of De Vries, the "plasomes" of Wiesner, the "idioblasts" of Hertwig, the "biophores" of Weismann. Such ultimate units have been found absolutely necessary to explain those most fundamental of all vital phenomena, assimilation and growth, while many other phenomena, especially particulate inheritance, the independent variability of parts, and the hereditary transmission of latent and patent characters, can at present only be explained by referring them to ultra-microscopical units of structure. To deny that there are such units does not simplify the problem, as some seem to suppose, but renders it impossible of approach. A corpuscular hypothesis of life, like that of light, may be only a temporary makeshift, but it is better than nothing.

Whitman * well says : "Brücke's great merit consists in this, that he taught us the necessity of assuming structure as the basis of vital phenomena, in spite of the negative testimony of our imperfect microscopes. That function presupposes structure is now an accepted axiom, and we need only extend Brücke's method of

* C. O. Whitman. The Inadequacy of the Cell Theory of Development. Biological Lectures, 1893 . 
reasoning from the tissue cell to the egg cell in order to see that there is no escape from the conclusion that the whole course of developmental phenomena must be referred to organization of some sort. Development, no less than other vital phenomena, is a function of organization."

3. A study of the phenomena of development, as well as the principle of causality, make it certain that all the characters of the species are preInherited charac- determined within the protoplasm of the ters predetermined in structure of germ cell. fertilized egg cell. From a frog's egg only a frog will develop, from an echinoderm egg only an echinoderm, and the course of the development is, under normal circumstances, definitely marked out in each case, even down to the minutest details. All the results of experiment, as well as observation and induction, only serve to render this conclusion the more certain. It should be observed that to affirm that characters are predetermined is a very different thing from saying they are preformed. The one merely asserts that the cause of the transformations which lead from one step to another in the development is determined by the initial conditions of the fertilized egg cell; the other affirms that those transformations have already taken place.

The absolute determinism of development depends primarily upon the constant structure of the egg cell, but also to a certain extent upon a definite relation to extrinsic factors. Since, however, these extrinsic factors may be exactly the same in two cases, and yet the result of development be very different (e. g., the egg of the starfish and that of the sea urchin), we can only conclude that while ontogenetic differences may be caused by a disturbance of the extrinsic factors, inherited characters are always the result of a definite structure of 
the germinal protoplasm, and that, therefore, development is, in the words of Professor Whitman, "a function of organization."

Inheritance and variation are general terms which include a great many different kinds of phenomena, many of which seem to be due to entirely different factors. A great many phenomena of inheritance seem to be due entirely to extrinsic forces, but a more careful inquiry always reveals the fact that they are invariably due to the reaction of certain extrinsic causes on a perfectly definite living structure. As examples may be mentioned the following:

(a) The tiger-like striping of the egg of Fundulus, which is very characteristic and would certainly be regarded as an inherited character, has been shown by Loeb* to be due entirely to the position of the blood vessels of the blastoderm. The pigment cells are at first uniformly distributed, but when the blood vessels are formed they gather around them, probably through chemotropic action, and thus the characteristic banded appearance is produced. Graf $\nmid$ has since shown that the colour patterns of leeches are produced in the same way. It is not necessary, therefore, to assume that the colour patterns in these cases are specifically represented in the germinal protoplasm; it may even be that the position of the blood vessels is not so represented, but there must be some ultimate cause back in the germinal plasm itself which determines the series of causes which finally produces the colour patterns. In short, this feature, like most others, was predetermined from the beginning.

* Jacques Loeb. Some Facts and Principles of Physiological Morphology. Biological Lectures, 1893.

† Arnold Graf. Ueber den Ursprung des Pigments und der Zeichnung bei den Hirudineen. Zool. Anzeiger, No. 468, 1895. 
(b) Herbst * has shown in a series of interesting experiments that by the use of various chemical substances the development of echinoderms may be profoundly modified. For example, in sea water deficient in calcium chloride, or in which there is an excess of potassium chloride, the Pluteus larva, instead of developing calcareous spicules and the long ciliated arms which give the normal larva an angular, easel-shaped appearance, remains rounded in shape much like the larva of Balanoglossus, in which no spicular skeleton is developed. The withdrawal, therefore, of certain normally present substances from the environment may profoundly modify the final result. But in this case, as in the other, it is absolutely certain that the calcareous spicules were predetermined in the egg cell, although in the absence of calcareous matter from the water those spicules could not be built-the plan was there, but the building material was lacking.

Such modifications resulting from unusual conditions of pressure, temperature, density, nutrition-in fact, any alteration of the chemical or physical environment-may appear in any stage of development from the unsegmented egg to the adult condition, but it must not be supposed that the entire development can be reduced to such factors. Loeb argues that we do not inherit our body heat from our parents because it depends upon certain chemical processes; but is it not absolutely certain that we inherit a certain protoplasmic structure which determines those chemical processes, and hence the body temperature? To assume that extrinsic causes determine whether there shall hatch from an egg a chicken or an eagle is the sheerest nonsense. The study of extrinsic factors in relation to inheritance will 
serve to simplify some of the intricate problems to be explained, but surely no one believes that development can ever be referred entirely to such factors. The fact is that determinism, which is the most fundamental characteristic of inheritance, is manifested at every step of development, and there is certainly no escape from the conclusion that this determinism depends upon protoplasmic structure, and that this structure it is which is transmitted from generation to generation, and which forms the physical basis of inheritance.

All really inherited characters must, therefore, be represented in the structure of the germinal protoplasm, and must consequently be present from the beginning of development. "We must consider it as a law derivable from the causality principle," says Hatschek, " "that in the phylogenetic alterations of an animal form the end stages are not alone altered, but the entire series from the egg cell to the end stage. Every alteration of an end stage or addition of a new one must be caused by an alteration of the egg cell itself." Nägeli $\nmid$ has expressed a similar view in the following famous sentence: "Egg cells must contain all the essential characteristics of the species as perfectly as do adult organisms, and hence they must differ from one another no less as egg cells than in the fully developed state. The species is contained in the egg of the hen as completely as in the hen, and the hen's egg differs as much from the frog's egg as the hen from the frog."

4. The remarkable tenacity of inheritance, as shown especially in reversions and the preservation of useless and embryonic characters through many hundreds or

* Berthold Hatschek. Ueber die Entwickelungsgeschichte von Toredo. Arb. Zool. Inst., Wien, I880.

+ Nageli. Mechanisch-physiologische Theorie der Abstammungslehre, I884. 
thousands of generations, and amid the most diverse circumstances, bears strong testimony to the great stability of that living structure which is the basis of inheritance. On the other hand, all experience goes to prove that the living substance of the body cells in general is readily modified, and that in a surprisingly short time. The fact of this great difference can not fail to be recognised; its cause is at present merely a matter of conjecture.

Weismann at one time supposed the cause of this to be an absolutely stable, absolutely separate, and perpetually continuous germ plasm. HowGerminal proto- ever, there is the most convincing and plasm relatively abundant evidence that although the but not absolutely stable. germ plasm is relatively very stable and continuous, it does not possess those divinely perfect characters ascribed to it. More recently Weismann has practically abandoned each and all of these characters, ${ }^{*}$ and now, like a good Lamarckian, finds "the cause of hereditary variation in the direct effects of external influences on the biophores and determinants."

The outcome of the whole matter, then, is that we find ourselves much in the same position as we were before Weismann denied the possibility of the inheritance of acquired characters. All hereditary variations are caused by the action of extrinsic forces on the germinal protoplasm, producing changes in its structure. Strangely enough, this proposition was admitted as a logical necessity by one who undertook by rigorous logic to prove the reverse. Since almost the only objection to this position was the one raised by Weismann, it may now be considered as definitely settled, and the only ques-

* See Romanes's Examination of Weismannism, I893. 
tion before us, then, is: How can extrinsic causes modify the structure of the germinal protoplasm ?

Since by his own admissions, as Romanes has shown, the most characteristic features of Weismann's system, both as to inheritance and evolution, have been virtually abandoned, it seems to some that his theories have been of no real value, and that, like an ignis fatuus, they have only served to lead biologists astray far from the path of science into the dangerous quagmires of speculation. I do not share any such opinion. Apart from his splendid observations and the great stimulus to investigation which Weismann's theories have furnished, there remain many elements of permanent value in his work.

Osborn* thinks that Weismann's most "permanent service to biology is his demand for direct evidence of the Lamarckian principle." It seems to me that his greatest service consists in the emphasis which he has laid upon the intrinsic factors of development and evolution as opposed to the extrinsic factors, a thing which he has indeed overemphasized but which has sadly needed a strong defender in these later years. Largely as an outcome of his work we now recognise the possibilities and the limitations of the selection theory as never before, and we also recognise that many of the evidences which were adduced in support of the Lamarckian factors are not conclusive, while the method of securing conclusive evidence is clearly marked out. Whatever we may think of his theories, this certainly is no slight service.

5. It is by no means an easy task to determine whether the influence of extrinsic forces has really reached the germinal protoplasm and modified its structure; much more difficult is it to determine how that

* Osborn. The Unknown Factors of Evolution. Biological Lectures, 1894 . 
modification takes place. I believe it is safe to say that a majority of the cases which are supposed to prove the inheritance of acquired characters prove only that characters are acquired, not that they are

Do external factors affect germinal protoplasm? inherited. There is great need of caution against supposing that any character is inherited unless it repeats itself under many and different conditions. Apart altogether from inheritance, similar conditions may produce similar results, and consequently this source of error must be eliminated if we would be certain that the structure of the germinal protoplasm has really been modified. Many of the alleged cases of the inheritance of mutilations, of the direct influence of the environment, and of use and disuse, fall away under this precaution.

The general evidence for the inheritance of mutilations is so notoriously bad that I pass it by altogether and select for consideration a few cases, chosen from a recent work on the subject, ${ }^{*}$ which have by various writers been alleged as showing the direct influence of environment in modifying species and also the inherited effects of use and disuse.

(a) It is well known that certain gasteropods if reared in small vessels are smaller than when grown in

Diminished nutrition. large ones, and this case has been cited as showing the influence of environment in modifying species. There is good evidence, however, that this modification does not affect the germinal protoplasm, for these same gasteropods will grow larger if placed in larger vessels. It seems very probable that the diminished size of these animals is due to deficient food supply, but this has so little I 896.

* E. D. Cope. The Primary Factors of Organic Evolution, 
modified the somatic protoplasm that, although they may be fully developed as shown by sexual maturity, they at once increase in size as soon as more abundant food is provided, and this takes place by the active growth and division of all the cells of the body. In higher animals, once maturity has been reached, there is little chance for growth, apparently because many of the cells are so highly differentiated that they can no longer divide; consequently the growth is limited, and hence the size of the adult may depend in part upon the amount of nutriment furnished to the embryo. This limitation of growth is due to the high degree of differentiation of the somatic cells. But as the germ cells are not highly differentiated and are capable of division, it follows that they would not be permanently modified by starving. It may be, as Professor Brewer argues, that long-continued starving and consequent dwarfing of animals may leave its mark on the germinal plasm; but, as he also remarks, this influence must be very slight as compared with the cumulative effects of selection in breeding, and it is safe to assert that there is no such wholesale and immediate modification of the germinal plasm due to the influence of nutrition as some people seem to suppose.

(b) The interesting experiments of Schmankewitsch in transforming one species of Artemia into another by Changes in environment. gradually increasing the salinity of the water, or in transforming Artemia into another genus, Branchinecta, by decreasing the salinity of the water, are well known and are often cited as illustrations of the fact that specific and even generic differences may suddenly be produced under the influence of the environment. The very fact, however, that these changes are suddenly produced, and that they can at will be quickly modified in one direction 
or the other, is evidence that they are not represented in the structure of the germinal plasm; and the fact that definite extrinsic causes, such as salt or fresh water, acting upon this plasm, produce results which are constantly the same is the best evidence that the internal mechanism-i. e., the structure of the germinal plasmis constantly the same. The same can be said of many artificially produced modifications, such as the exogastrulas and potassium larvæ of Herbst, all of which profound changes are due entirely to extrinsic and not to intrinsic causes, as is shown by the fact that they disappear as soon as the immediate extrinsic cause is withdrawn. The same thing is shown in Poulton's experiments on the colours of lepidopterous larvæ, and in this case also it is known that the changes are not inherited, at least during the limited period through which the experiments were conducted; and it should be observed that to assume that this would take place at the end of an indefinite number of generations is simply to beg the question.

Very many other cases of a similar character might be instanced under this head, but I hasten on to another class of evidence.

(c) Under the subject of the inherited effects of use Use and disuse. and disuse the following cases may be mentioned as showing how inconclusive much of the evidence is:

(x) In the first place, this whole line of argument starts with the assumption that the individual habits of an animal are inherited, and that these habits ultimately determine the structure, an assumption which really begs the whole question; for, after all, the substratum of any habit must be some physical structure, and if modified habits are inherited it must be because some modified structure is inherited. I take an example 
which will serve as an illustration of a whole class: Jackson* says that the elongated siphon of Mya, the long-necked clam, is due to its habit of burrowing in the mud, or to quote his words: "It seems very evident that the long siphon of this genus was brought about by the effort to reach the surface, induced by the habit of deep burial." It certainly would be pertinent to inquire where it got this habit, and how it happened to be transmitted. It is surely as difficult to explain the acquisition and inheritance of habits, the basis of which we do not know, as it is to explain the acquisition and inheritance of structures which are tangible and visible. Such a method of procedure, in addition to begging the whole question, commits the further sin of reasoning from the relatively unknown to the relatively known.

This case is but a fair sample of a whole class, among which may be mentioned the following: The derivation of the long hind legs of jumping animals, the long fore legs of climbing animals, and the elongation of all the legs of running animals through the influence of an inherited habit. All such cases are open to the very serious objection mentioned above.

(y) Another whole class of arguments may be reduced to this proposition: Because necessary mechanMechanical conditions. ical conditions are never violated by organisms, therefore modifications due to such conditions show the inheritance of acquired characters. Plainly, the alternative proposition is this: If acquired characters are not inherited, organisms ought to do impossible things.

(z) Many of the arguments advanced to prove the inheritance of characters acquired through use or disuse seem to me to prove entirely too much. For ex-

* R. T. Jackson. Memoirs Boston Soc. Nat. Hist., 1890. 
ample, Professor Cope argues very ably that bones are lengthened by both stretch and impact, and that modifications thus produced are inherited. Even granting that this is true, how would it be possible for this process of lengthening to cease, since in active animals the stretch and impact must be continual ? Professor Cope answers that the growth ceases when "equilibrium" is reached. I confess I can not understand this explanation, since the assumed stimulus to growth must be continual. But, granting again that growth may stop when an animal's legs become long enough to "satisfy its needs," how on this principle are we to account for the shortening of legs, as, for example, in the turnspit dog and the ancon sheep and numberless cases occurring in Nature? If any one species was able, by taking thought of mechanical stresses and strains, to add one cubit unto its stature, how could the same stresses and strains be invoked to decrease its stature?

These evidences are, I know, not the strongest ones which can be adduced in support of the Lamarckian factors. There are at present a relatively small number of such arguments which seem to be valid and the great force of which I fully admit. But the cases which I have cited are, I believe, fair samples of the majority of the evidences so far presented, and in the face of such "evidence" it is not surprising that one who is himself a profound student of the subject and a convinced Lamarckian prays that the Lamarckian theory may be delivered from its friends.*

6. Another line of evidence, and by far the most promising, is that of direct experiment. So far, most of the experiments which have been carried on to determine this question have been carried only halfway to a

* H. F. Osborn. Evolution and Heredity. Biological Lectures, 1890 . 
conclusion-they have shown that characters are acquired, they have usually failed to show that they are transmitted to descendants. Among animals one of the

Value of direct best-known cases is the inheritance of experiment. epilepsy and other disorders in guineapigs, due to certain nervous lesions of the parents. But Romanes, * who spent much time in trying to corroborate these results, concludes as follows: "On the whole, then, as regards Brown-Séquard's experiments, it will be seen that I have not been able to furnish any approach to a full corroboration."

Among plants, on the other hand, there is more and better experimental evidence, but it is not by any means as full or satisfactory as could be wished. Of one thing we may be certain-a satisfactory solution of the problem can be reached only by experiment. The mere observations and inductions of the morphologist, while affording valuable collateral evidence, can never furnish the crucial test. As long as we deal merely with probabilities of a low order there will be profound differences of opinion-e. g., Cope believes in all the Lamarckian factors ; Romanes rejects use and disuse, but believes in the others; Weismann rejects all of them. Why? Is it because each does not know the facts upon which the others build? Certainly not. Those so-called facts are merely probabilities of a higher or lower order, and to one man they seem more important than to another. No conviction based even upon a high degree of probability can ever be reached in this way. There is here a deadlock of opinion, each challenging the other to produce indubitable proof. This can never be furnished by observation alone. Possibly even experiment may fail in it, but at least it is the only hope.

* G. J. Romanes. Post-Darwinian Questions, I895. 
On the whole, then, I believe the facts which are at present at our disposal justify a return to the position of Darwin. Neither Weismannism nor

Return to the position of Darwin. Lamarckism alone can explain the causes of evolution. But Darwinism can explain those causes. Darwin endeavoured to show that variations, perhaps even adaptations, were the result of extrinsic factors acting upon the organism, and that these variations or adaptations were increased and improved by natural selection. This is, I believe, the only ground which is at present tenable, and it is but another testimony to the greatness of that man of men that, after exploring for a score of years all the ins and outs of pure selection and pure adaptation, men are now coming back to the position outlined and unswervingly maintained by him.

Finally, we ought not to suppose that we have already reached a satisfactory solution of the evolution problem, or are, indeed, near such a

The final word still far distant. solution. "We must not conceal from ourselves the fact," says Roux, "that the causal investigation of organism is one of the most difficult, if not the most difficult, problem which the human intellect has attempted to solve, and that this investigation, like every causal'science, can never reach completeness, since every new cause ascertained only gives rise to fresh questions concerning the cause of this cause." 


\section{V.}

\section{THE HEREDITY OF RICHARD ROE.}

"Vom Vater hab' ich die Statur." *-Goethe.

WHEN Richard Roe was born, "the gate of gifts was closed" to him. Henceforth he must expect nothing

Formation of character. new and must devote himself to the development of the heritage he had received from his father and mother.

He must bring its discordant elements into some sort of harmony. He must form his Ego by the union of these elements. He must soften down their contradictions. He must train his elements of strength to be helpful to some one in some way, that others may be helpful

* "Stature from father and the mood Stern views of life compelling ; From mother, I take the joyous heart And the love of story-telling.

" Great-grandsire's passion was the fair, What if I still reveal it?

Great-granddam's, pomp and gold and show, And in my bones I feel it.

"Of all the various elements That make up this complexity, What is there left when all is done, To call originality ?"

Gozthe: Zahme Xenien, vi; Bayard Taylor's translation in part. 
to him. He must give his weak powers exercise, so that their weakness shall not bring him disaster in the competition of life. For it is likely that somewhere, somehow, it will be proved that no chain is stronger than its weakest link. Other powers not too weak, nor over strong, Richard Roe must perforce neglect, because in the hurry of life there is not time for every desirable thing. In these ways the character of Richard Roe's inheritance is steadily changing under his hands. As he grows older, one after another of the careers that might have been his, the men he might have been, vanish from his path forever. On the other hand, by steady usage a slender thread of capacity has so grown as to become like strong cordage. Thus Richard Roe learns anew the old parable of the talents. The power he hid in a napkin is taken away altogether, while that which is placed at usury is returned a hundredfold.

Now, for the purpose of this discussion, you, gentle reader, "who are an achievement of importance," or I, ungentle writer, concerning whom the less said the better, may be Richard Roe. So might any of your friends or acquaintances. So far as methods and principles are concerned, Richard Roe may be your lapdog or your favourite horse-or even your bête noire, if you cherish beasts of that character. Any beast will do. With Algernon Fitzclarence de Courcy or Clara Vere de Vere the case would be just the same. Let Richard Roe stand at present for the lay figure of heredity-or, if it seems best to you to humanize this discussion, let him be a man.

The man Richard Roe enters life with a series of qualities and tendencies granted him by heredity. Let

Hereditary tendencies. us examine this series. Let us analyze the contents of this pack which of the Golden City. he is to carry through life to the gates 
First, from his parents, Richard Roe has inherited humanity, the parts and organs and feelings of a man. Inheritance of "Hath he not eyes? Hath he not hands, humanity. organs, dimensions, senses, affections, passions? fed with the same food, hurt with the same weapons, subject to the same diseases, healed by the same means, warmed and cooled by the same winter and summer" as you or I or any other king or beggar we know of? "If you prick us, do we not bleed? if you tickle us, do we not laugh? if you poison us, do we not die? if you wrong us, shall we not revenge?" All this, the common heritage of Jew or Gentile, goes to the making of Richard Roe. His ancestors on both sides have been human, and that for many and many generations, so that "the knowledge of man runneth not to the contrary." Even the prehuman ancestry, dimly seen by the faith of science, had in it the potentialities of manhood. Descended for countless ages from man and woman, man born of woman Richard Roe surely is.

We may go farther with certainty. Richard Roe will follow the race type of his parentage. If he is AngloInheritance of race characters.

Saxon, as his name seems to denote, all Anglo-Saxon by blood, he will be all Anglo-Saxon in quality. To his characters of common humanity we may add those common to the race. He will not be negro nor Mongolian, and he will have at least some traits and tendencies not found in the Latin races of southern Europe.

But his friends will know Richard Roe best not by the great mass of his human traits nor by his race characteristics. These may be predomiIndividual characters. nant and ineradicable, but they are not distinctive. He must be known by his peculiarities, by his specialties and his deficiencies. 
Within the narrowest type there is room for an almost infinite play in the minor variations. For almost any possible one of these, Richard Roe could find warrant in his ancestry. His combination of them must be his own. That is his individuality. Colour of the eyes and hair, length of nose, hue of skin, form of ears, size of hands, character of thumb prints, in all these and ten thousand other particulars some allotment must fall to Richard Roe.

He must have some combination of his own, for Nature has "broken the die" in moulding each of his ancestors, and will tolerate no servile copy of any of her works. By the law of sex, Richard Roe has twice as many ancestors as his father or mother had. Therefore these could give him anything they had severally received from their own parents. The hereditary gifts must be divided in some way, else Richard Roe would be speedily overborne by them. Furthermore, any system of division Nature may adopt could only be on the average an equal division. Richard Roe's father might supply half his endowment of inborn characters, his mother furnishing the other half. Nature tries to arrange for some partition like this. But she can never divide evenly, and some qualities will not bear division. Richard Roe's share forms a sort of mosaic, made partly of unchanged characters standing side by side in new combinations, partly a mixture of characters, and part of characters in perfect blending.

The physical reason for all this the physiologists are just beginning to trace. The machinery of division and The germ cell. integration they find in the germ cell At the same time they find that Nature's love of variation is operative even here. She has never yet made two eggs or two sperm cells exactly alike. 
The germ cell, male or female-and the two are alike in all characters essential to this discussion-is one of the vital units or body cells set apart for a special purpose. It is not essentially different from other cells, either in structure or in origin. But in its growth it is capable of repeating the whole organism from which it came, "with the precision of a work of art."

The germ cell is made up of protoplasm, a jelly-like substance, less simple than it appears, not a "subProtoplasm. stance" at all, in fact, but a structure as complex as any in Nature. In connection with this structure all known phenomena of life are shown. Inside the germ cell, or in any other cell, is a smaller cellule called the nucleus. In connection with the nucleus appear most of the phenomena of hereditary transmission. Its structure in the higher animals is a complicated arrangement of loops and bands, the material of which these are made being called chromatin. This name, chromatin, is given beChromatin.

cause its substance takes a deeper stain or colour (chroma in Greek) than ordinary protoplasm or other cell materials. In the chromatin are the determinants of heredity, and these preside in some way over all movements and all changes of the protoplasm. In the fertilized egg, the mixed chromatin* of the two cells which have been fused into one may be said to contain the architect's plan by which the coming animal is to be built up. In the mixed chromatin of the cell which is to grow and to divide, to separate and integrate, till it forms Richard Roe, the potentialities of Richard Roe all lie in some way hidden. How this is we can not tell. We know that the structure of a single cell is a highly complex matter, more

* For a discussion of this and other views more or less hypothetical, see the essay on the Physical Basis of Heredity. 
complex than the Constitution of the United States, with a far more perfect system of checks and balances. When we can understand all that takes place in a single cell we shall "know what God is and what man is." It is not, like the Constitution of our nation, a simple written document with definite powers and definite limitations. It may rather be compared to the unwritten constitution of civilization, and a single cell may hold in potentiality even all that this supposed constitution may embrace. It is not easy, for example, to understand how Richard's tone of voice, or the colour of his hair, or his ear for music, or other hereditary qualities can be thus hidden. But so they seem to be, and if Science should stop whenever she came to a problem we cannot think out, the growth of knowledge would be hemmed in more closely than it is now.

When Nature is getting the germ cells ready, the hereditary material or chromatin is increased in each one and then again divided and subdivided, till in the ripened cell but half the usual amount is present.* The cell is then ready to unite with its fellow to form a perfect cell, from which, under favourable circumstances, the great alliance of cells which constitute the body of Richard Roe can be built up.

Nature makes her divisions evenly enough, but never quite equally. She is satisfied with an approximate

Inequality of

Nature's

divisions. equality, better satisfied than if she could make a perfect division. She knows no straight lines, she never made a perfect sphere, and she takes the corner away from every angle. It satisfies her desire for likeness to have her children almost alike. Exact symmetry would exclude variation, for which she cares

* This explanation is probable but not certain. 
still more than for likeness, and for good reason. If her creatures are left unlike, it is so much the easier for her to find places for them in the crowded world of life. Moreover, unlikeness gives play for selection. She can save her favourites and discard her failures.

So in the chromatin of his two parents Richard Roe finds his potentialities, his capacities, and his limitaAtavism. tions. But latent in these are other capacities and other limitations handed down from other generations before them. Each grandfather and grandmother has some claim on Richard Roe, and behind these dead hands from older graves are still beckoning in his direction. The past will not let go, but with each generation the dust or the crust grows deeper over it. Moreover, these old claims grow less and less with time, because with each new generation there are twice as many competitors. Besides this, as we shall see beyond, these past generations can make no claim on him except through the agency of his own parents.*

* We may sum up Richard Roe's inheritance by making use of the formulæ of algebra, a science which deals with unknown characters that bear definite relations to each other.

Let $A$ be the aggregate of species and race characters inherited from the father. Let $A^{\prime}$ be the species and race characters inherited from the mother. Then $\frac{A+A^{\prime}}{2+2}$, as $A=A^{\prime}$, will amount to A again. A forms the greater part of Richard Roe in numerical aggregate, but in the Anglo-Saxon race it is an invariable quantity, and therefore not of importance in making up the character by which we know him from his fellows.

Let $B$ be the recognisable peculiarities of the father, and $B^{\prime}$ the recognisable peculiarities of the mother. How shall these be divided? Obviously not more than $\frac{B+B^{\prime}}{2+2}$ should be expected, for a body can not be made up of peculiarities. We may infer from Galton's studies that these figures are in excess of the 
Out of these elements Mr. Galton frames the idea of a "mid-parent," a sort of centre of gravity of heredity, The mid-parent. which in language, not algebra, would represent the same set of ideas. But, as Dr. Brooks has observed, "It may be well to ask what evidence there is that the child does inherit from any ancestor except its parents, for descent from a long line of ancestors is not necessarily equivalent to inheritance from them, and it is quite possible that the conception of a 'mid-parent' may be nothing but a logical abstraction." * The parents of Richard Roe were his father and

fact. In each process of generation, half these qualities, already once divided, are lost or rendered unrecognisable by individual variations or by contradictory blendings. To each parent Galton assigns about twenty-five per cent of these personal qualities. Accepting this as approximate, $\frac{\mathrm{B}}{4}+\frac{\mathrm{B}^{\prime}}{4}$ would be nearer the actual fact, and we may so take it. But the latent influence of the grandparents must come in, these represented by $\mathrm{C}, \mathrm{C}^{\prime}, \mathrm{C}^{\prime \prime}$, and $\mathrm{C}^{\prime \prime \prime}$ respectively. In this case the divisor may apparently be 16 , which corresponds to Galton's estimate of $6 \frac{2}{3}$ per cent. Should we wish to go farther back, the influence of the greatgrandparents, D, $\mathrm{D}^{\prime} \mathrm{D}^{\prime \prime}$, etc., eight of them, could be added, each with 64 as its divisor.

It is evident that these divisors are all proximate only, and varying at each cleavage of the germinal chromatin. The unknown and fluctuating element in this division we may designate as $\pm n$. Hence $\frac{\mathrm{B}}{4 \pm n}$ would represent the direct heritage of his father to Richard Roe. Then $\mathrm{A}+\frac{\mathrm{B}}{4 \pm n}+\frac{\mathrm{B}^{\prime}}{4 \pm n}+\frac{\mathrm{C}}{\mathrm{I} 6 \pm n^{2}}+\frac{\mathrm{C}^{\prime}}{\mathrm{I} 6 \pm n^{8}}$ $+\frac{\mathrm{C}^{\prime \prime}}{\mathrm{I} 6 \pm n^{2}}+\frac{\mathrm{C}^{\prime \prime \prime}}{\mathrm{I} 6 \pm n^{2}}+\frac{8 \mathrm{D} \text { etc. }}{64 \pm n}+\frac{16 \mathrm{E} \text { etc. }}{256 \pm n^{4}}$, etc., will be our first rough draft of the hereditary framework of Richard Roe.

* In that case the formula given in the above note would be modified to this extent. The value of C, D, E, etc., would be limited to the hereditary characters latent but undeveloped in B, etc. Their value would be less than B, for some part of B would 
mother, not his grandfather or grandmother, nor yet the whole human race, in one of the chains of which he forms a single link. When a son inherits his maternal grandfather's beard it is really his mother's beard which he acquires. It is the beard which his mother would have had had she been a man.

Dr. Brooks says: "When the son of a beardless boy grows up and acquires a beard, we may be permitted to say that he has inherited his grandfather's beard; but this is only a figure of speech, and he actually inherits the beard his father might have acquired had he lived; nor would the case of a child descended from a series of ten or a hundred beardless boys be any different." *

The species and race characters being the same for father and mother, must be the same for the son. They

have to be subtracted from each of them. For it is evident that the inheritance from the grandparents and from far-off ancestors came through the parents. If not active in them, these qualities must have been latent, and in either case they came from them to Richard Roe. In strictness the inheritance of C, D, E, etc., is included in B, as are also the race qualities and the qualities of the species.

* Setting aside these considerations, it is evident that, as $\mathrm{A}+\mathrm{B}$, $A+B^{\prime}, A+C, A+D^{\prime \prime}$, etc., represent each a distinct personality, Richard Roe from the first will differ notably from $A+B$, assumed as the original formula of his father. To what extent this difference goes depends on the value of $\mathrm{A}$ as compared with $B, B^{\prime}$, etc. ; in other words, on the uniformity of the pedigree. If $B, C, D$ and the rest were very closely alike, as is the case with "thoroughbreds," the differential elements will be small, and the complete Richard Roe will be very like the rest of them. If $\mathrm{B}, \mathrm{C}, \mathrm{D}$ are small quantities, and $\mathrm{A}+\mathrm{B}$ essentially similar to $\mathrm{A}+\mathrm{D}$, the addition of $\frac{\mathrm{C}}{16 \pm n}$ will count for but little in the aggregate. To be thoroughbred is to be bred so as to exclude individual variation. It tends to prevent failures or deficiencies, and at the same time it tends to limit advance. 
are added together and divided by two. Half comes from each side in the process of inheritance, but the two halves are alike. But the personal peculiarities recognisable in the father are different from those seen in the mother. The son can not inherit all from both sources. Certainly not more than half could come from either source, for the new generation could not be built of peculiarities alone. The old large, common heritage must always have precedence. Galton has made a calculation (referred to in the note above), based on wide observations, that on the average 25 per cent of the individual peculiarities are directly inherited from each parent. On the average, each parent exerts the same force of heredity. Half the characters come from each, but in each half it would appear that about one half is lost or rendered unrecognisable by other variation or by contradictory blendings. The first division of qualities in half is necessary and natural, for there are two parents. The second division in half is an arbitrary assumption which seems to find its warrant in Galton's studies. We might assume without theoretical difficulty a third or a fifth as being preserved intact among possible variations and combinations. One half, however, seems nearer the fact, and to find the fact is the only purpose of theory. To the characters received from the parents we must add the latent influence of grandparents, great-grandparents, and the long array of dead hands which, however impotent, can never wholly let go. As the smallest wave must go on, in theory at least, till it crosses the ocean, so the influence of every ancestor must go on to the end of the generation. Each of us must feel in a degree the strength or weakness of each one of them. To each grandparent Galton assigns $6 \frac{2}{3}$ per cent. There are four grandparents and two stages of generation separate them from Richard Roe. Half the force of each, 
twice lost, seems to give to each grandparent one fourth the potency in heredity the father or mother has. In the same way to the great grandparent we must assign the relation of $1 \frac{9}{16}$ per cent (one sixty-fourth), and so on.

The "bluer" the blood-that is, the more closely alike these ancestors are-the greater will be the comThe thoroughmon factor, the less the amount derived bred.

from the individual. In perfect thoroughbreedings the individual should have no peculiarities at all. This condition is never reached, but it may sometimes be approximated. In such case the addition of an ancestral sixteenth or sixty fourth could make no visible change. This may be true among the very bad as well as among the very good. Weakness or badness are more often thoroughbred than strength or virtue. The bluest of blood may run in the veins of the pauper as well as in the aristocrat who boasts that $\frac{W}{2147473648 n \pm}$ in his formula stands for William the Norman. And for Richard Roe's own sake let us hope that he is not too thoroughbred, and that he has no record of $W$ and $W^{\prime \prime \prime}$, nor even of $E$. Too narrow a line of descent tends to intensify weaknesses. Vigour and originality come from the mingling of variant elements. Nature does not favour "in-and-in breeding." There is no loss to the individual if decided and different qualities come from father or mother. Contradictory or even incongruous peculiarities are better than none at all.

Ancestry, too, like wine, becomes stale if it remains too long in the sunshine. An ancestry which is readily traced has lived too long in easy places. A few generations of successful dealing with small matters may prepare the way for the power to deal with great ones. 
Wisdom is knowing what to do next, and wisdom may exist in humble as well as conspicuous fields of action.

Again, at the time of Richard Roe's birth, the formula of his father was slowly changed, under the reChanges through action toward activity or to idleness, Changes through resulting from his efforts and his enexperience.

vironment. If it was originally and potentially $A+B$, and that of his father $A^{\prime}+B$, it is now no longer so. Changes constantly arise from the experiences of life, the stress of environment, the reduction of "mental friction," the formation of automatic nervous connections or habits, the growth through voluntary effort, the depression from involuntary work or idleness, the degeneration through the vitiation of nerve honesty caused by stimulants or vice, the deterioration due to spurious pleasures that burn and burn out.

Each of these may have come to the father of Richard Roe, and each one had left its mark on him. The fairy's wand and the fool-killer's club each leaves an indelible trace whenever it is used. Through these influences* every man is changed from what he was or what he might have been to what he is.

* Let $\mathrm{X}$ be the aggregate of gains and $\mathrm{Y}$ of losses due to these acquired qualities. In the case of the mother these may be $\mathrm{X}^{\prime}$ and $\mathrm{Y}^{\prime}$. In this case $\mathrm{X}$ and $\mathrm{Y}, \mathrm{X}^{\prime}$ and $\mathrm{Y}^{\prime}$, represent large factors, but excessively diverse and varying, affecting in some degree all the qualities contained in the symbols B and $\mathrm{B}^{\prime}$. Richard Roe's father would then be $A+B+X-Y$. His mother $A+B^{\prime}+$ $\mathrm{X}^{\prime}-\mathrm{Y}^{\prime}$. These added numbers mark the change from what these two ought to have been or would naturally have been toward what they are. How much of this is inherited? How do these characters affect Richard Roe? How much of X and $\mathrm{Y}$ shall we place in his formula? Some learned investigators, notably August Weismann and Alfred Russell Wallace, say that these changes count for nothing in heredity. $\mathrm{X}$ and $\mathrm{Y}$ spend their 
Lamarck's much-discussed "fourth law" of development reads as follows: "All that has been acquired, begun, or changed in the structure of the Inheritance of acquired characters. individuals in their lifetime is preserved in reproduction and transmitted to the new individuals which spring from those who have inherited the change."

"Change of function produces change of structure," so Herbert Spencer tells us; "it is a tenable hypothesis that changes of structure thus produced are inheritable."

But though this may be a tenable hypothesis, the opposite hypothesis has not been clearly shown to be intenable. It seems to be true that any great physical weakness on the part of Richard Roe's parents would tend to lower his constitutional vigour, whatever the origin of such weakness might be. If so, such weakness might appear as a large deficiency in his power of using his equipment. It may be, too, that any extreme degree of training, as in music or mathematics, might determine in the offspring the line of least resistance for the movement of his faculties. Perhaps Richard Roe would find

force on the generation that develops them. Acquired characters are never inherited. Other investigators, equally wise, Herbert Spencer and Lester F. Ward, for example, do not admit that any gain or loss to the individual is without its effect on succeeding generations, and thus on the species. $\mathrm{X}$ and $\mathrm{Y}$ are inherited just as $\mathrm{B}$ or $\mathrm{B}^{\prime}$ may be.

Let us assume that they are inherited in some degree, and let us represent this inheritance of acquired characters as $\frac{X+X^{\prime}-Y-Y^{\prime}}{Q}$. The divisor $\mathrm{Q}$ reducing all acquired characters of the parent is an unknown quantity of large and perhaps variable value. If large, the value of the fraction will be correspondingly small. In Weismann's view, $Q$ should equal infinity, in which case $\frac{X}{Q}$ or $\frac{Y}{Q}$ would be nothing at all. This would be the symbol of non-inheritance. 
mathematics easier had his father devoted his life to exercise of that kind. But we are not sure that this is so. We do not know yet on what terms $\mathrm{X}$ and $\mathrm{Y}$ and $\mathrm{X}^{\prime}$ and $\mathrm{Y}^{\prime}$ are passed over to Richard Roe, or whether they are passed on to him at all. In the view of Herbert Spencer ("Neo-Lamarckism") $\mathrm{X}$ and $\mathrm{Y}$ are inherited, just as A and B are. According to Weismann and his followers they are not subjects of heredity at all.

I can not pretend to say what will be the final decision of science in regard to this vexed question. I venture. to suggest that in Lamarck's law and in the theories of many of his modern followers, too high value has been set, not on $X$ and $Y$, but on $\frac{X}{Q}$ and $\frac{Y}{Q}$. On the other hand, if these fractions are really equal to zero, if acquired characters are absolutely of no value in heredity, some problems in biology we have thought easy become tremendously complicated. We must rewrite a large portion of the literature of sociology. We must give a new diagnosis to Ibsen's Ghosts. We must, in fact, do this in any event, for inheritance such as the Norwegian dramatist pictures it, belongs not to heredity at all, but is to be sought for among the phenomena of transmission and nutrition. They are matters of vegetative development rather than of true heredity. Of the same nature is probably the recurrence of "spent passions and vanished sins" that certain psychologists ascribe to heredity.

We may, I think, set aside the inheritance of acquired characters as not being a large factor in the

Nature of acquired characters. changes of. the higher animals. Properly speaking, as Mr. Archdall Reid has well shown, nearly all the characters of the adult are "acquired characters" as distinguished from innate characters. Heredity, for ex- 
ample, does not give to the grown man his characteristics. It gives only the power to acquire them. Just as excessive muscular development requires excessive use of the arm, so average development of any organ is conditioned on an average degree of normal activity.

"Therefore," says Mr. Reid, " $i t$ is clear that the full development of the normal adult arm as well as many other important structures is acquired, differing in this from eyes, ears, teeth, nails, etc., which are wholly inborn and do not owe their development in the least to use and exercise. It will be found that adult man differs physically from the infant almost wholly in characters which are acquired, not in those which are inborn. In teeth, hair, skull bones, and some other respects he differs from the infant as regards inborn characters, but as regards almost all of the structures of the trunk and limbs and most of those of the head, the difference is in characters which have been acquired by the adult as a response to the stimulation of exercise and use. . . But variations acquired as a result of use and disuse are plainly never transmitted. Thus an infant's limb never attains the adult standard except in response to the same stimulation (exercise) as that which developed the parent's limb. The same is true of all the other structures which in the parent underwent development as a result of use or subsequent retrogression in the absence of it. These, like the limbs, do not develop or retrogress in the infant except as a result of similar causes. Plainly, then, what is transmitted to the infant is not the modification, but only the ponerer of acquiring it under similar circumstances, a power which has undergone such an evolution in high animal organisms that, as I say in man, for instance, almost all the development changes which occur between infancy and manhood are attributable to it. "The power of acquiring fit modifications in response 
to appropriate stimulation is that which especially differentiates high animal organisms from low animal organisms.

"Without this power and the plasticity which results from it the multitudinous parts of high animals could not well be co-ordinate, and therefore without it their evolution could scarcely have been possible. Indeed, it is not too much to say, so vitally important is this power to the higher animals, that as regards them the chief aim (if I may use the expression) of natural selection has been to evolve it."*

One more element, likewise of doubtful value, must be added to the inventory of Richard

Prenatal influences.

Roe. This is the element of prenatal influence on the part of his mother.

In the process of evolution the development of the female has brought her to be more and more the protector and helper of the young. She gives to her progeny not only her share of its heredity, but she becomes more and more a factor in its development.

In the mammalia the little egg is retained long in the body and fed, not with food yolk, but with the mother's blood. The "gate of gifts" is not closed with the process of fertilization as it is in the lower forms. If the help of favourable environment can be counted as a gift, this gate is not closed at birth nor so long as the influence of the mother remains. By the growth of the human family the parental environment becomes a lifelong influence. The father as well as the mother becomes a part of it. In Walt Whitman's words :

" His own parents (he that had fathered him and she that had conceived him in her womb and birth'd him),

They gave this child more of themselves than that,

They gave afterward every day, they became part of him."

* Archdall Reid, Science, December I7, r897, p. 901. 
It has long been a matter of common belief that among mammals a special formative influence is exerted by the mother in the period between conception and birth. The patriarch Jacob is reputed to have made a thrifty use of this influence in relation to the herds of his father-in-law Laban. This belief is part of the folklore of almost every race of intelligent men. In the translations of Carmen Silva, that gentle woman whom kind Nature made a poet and cruel fortune a queen, we find these words of a Roumanian peasant woman :

" My little child is lying in the grass, His face is covered with the blades of grass. While I did bear the child, I ever watched The reaper work, that it might love the harvests; And when the boy was born, the meadow said, 'This is my child."

In the current literature of hysterical ethics we find all sorts of exhortations to mothers to do this and not to do that, to cherish this and avoid that on account of its supposed effect on the coming progeny. Long lists of cases have been reported illustrating the law of prenatal influences. Most of these records serve only to induce scepticism. Many of these are mere coincidences, some are unverifiable, some grossly impossible, and some read like the certificates of patent medicines. There is an evident desire to make a case rather than to tell the truth. The whole matter is much in need of serious study, and the entire record of alleged facts must be set aside to make an honest beginning.

Dr. Weismann ridicules it all and believes that all forms of mother's marks, prenatal influences, and the like, are relics of mediæval superstition. Other authorities of equal rank, as Henry Fairfield Osborn, believe that these supposed influences exist and are occasionally made evident. Doubtless most of the current stories 
are products of self-deception or plain lying.* Probably the period of gestation is too short for peculiar nervous states to produce far-reaching changes in hereditary endowments. On the other hand, doubt and ridicule are not argument, and there may be some reality in influences in which the world has so long believed; but these phenomena, if existing, belong to the realm of abnormal nerve action or of altered nutrition, not to heredity.

The value of the prenatal influences acting upon Richard Roe we may indicate as $Z$, giving the symbol an indefinite and, if you please, a low value. But this is not the whole story. There are many phenomena of transmitted qualities that can not be charged to heredity. Just as a sound mind demands a Transmission of impaired vitality. sound body, so does a sound child de. mand a sound mother. Bad nutrition before as well as after birth may neutralize the most vigorous inheritance within the germ cell. A child well conceived may yet be stunted in development. Even the father may transmit weakness in development as a handicap to hereditary strength. The many physical vicissitudes between conception and birth may determine the rate of early growth or the impetus of early development. In a sense, the impulse of

* For example, Dr. Fearn cites the following case: “A mother witnessed the removal of one of the bones (metacarpal) from her husband's hand which greatly shocked and alarmed her. A short time after she had a child who was born without the corresponding bone which was removed from the father." (Report of Medical Association of Alabama, 1850, as quoted by Dr. S. B. Elliott in the Arena, March, 1894.) If this report is true, our ideas of the formation and dissolution of parts of the skeleton must be materially changed. We must believe either that the metacarpal bones are formed just before birth, after all the rest of the skeleton, or else that bones once formed may be reabsorbed under the influence of nervous shock or hysteria. Either view is nonsense. 
life comes from such sources outside the germ cell and outside of heredity. All powers may be affected by it. Perfect development demands the highest nutrition, an Ibsen's Ghosts. ideal never reached. In such fashion the child may bear the incubus of Ibsen's "Ghosts" for which it had no personal responsibility. "Spent passions and vanished sins" may impair germ cells, male or female, as they injure the organs that produce them. We must then represent the perfection of transmission by $\mathrm{T}$, and $\mathrm{T}$ is a fraction, large or small, but always less than unity. It would stand as a reducing agency, and as such in algebra it would be best represented as a divisor. The whole formula may be multiplied by $\frac{\mathrm{I}}{\mathrm{T}}$, a process that, like the process $\mathrm{Z}$, which if it exists is an extension of $\mathrm{T}$, must intervene between conception and birth.

This formula indicates simply the possibilities of Richard Roe as the sexless embryo, the joined protoDetermination of sex.

plasm and united chromatin of the two parent germ cells. This germ has now to grow and expand by cell division. But besides its vegetative growth two possible lines of development lie before it, one of which it must take. It must assume sex. It must become either male or female. The choice of the one at the critical time is as feasible as that of the other. But once made the choice is irrevocable. Thus far man has found no way to control this choice and Nature makes it for him. The sexless embryo is, as it were, suspended on a hair, to be turned to male or female by the first stimulus which may reach it. In the human race, such impulses must come through the mother. Certain of these forces have been partially defined.

It has long been known that with certain insects and crustaceans full nutrition increases the number of fe- 
males; starvation of the mother makes the young male. It may be so with the human race. In accordance with certain known facts and certain plausible theories, Dr. Schenck, of Vienna, has formulated certain rules for the control of sex in offspring. Among other things a proteid or "training-table" diet before and through the critical period of early pregnancy should increase the probability of male offspring; a fat-producing diet should tend to insure a daughter. Other suggestions have been made which need not be discussed here. In general, we may say that the determination at will of sex in offspring is not theoretically impossible. The elements involved are too obscure and complex for certainty to be probable. It is, moreover, an open question whether the general diffusion of such power would be a boon to mankind.

In any event, Richard Roe became male. Whether through the lean diet of his mother or the late union of his parent germ cells, or through some hidden cause or impulse need not concern us now. The fact of masculinity becomes more and more dominant as his growth goes on. At last it affects all his activities, modifies all his structures, and permeates every fiber of his being. Then is Richard Roe a man, and our formula of his possibilities is multiplied or modified by an overshadowing M. (male). But his hereditary characters are arranged and assigned before the question of his sex is deterFormula of life. mined by Nature. Thus at birth we may designate Richard Roe by the formula $\frac{\mathrm{I}}{\mathrm{T}}\left(\mathrm{A}+\frac{\mathrm{B}}{4 \pm n}+\frac{\mathrm{B}^{\prime}}{4 \pm n}+\frac{\mathrm{C}}{\mathrm{I} 6 \pm n^{2}}+\frac{\mathrm{C}^{\prime}}{\mathrm{I} 6 \pm n^{2}}\right.$, etc., $+\frac{\mathrm{D}}{64 \pm n^{2}}+\frac{\mathrm{D}^{\prime}}{64 \pm n^{3}}$, etc., $+\frac{\mathrm{E}}{25^{6} \pm n^{4}}$, etc. $+\frac{\mathrm{F}}{1024 \pm n^{6}}$, etc., $+\frac{X}{Q}+\frac{X^{\prime}}{Q}-\frac{Y}{Q}-\frac{Y^{\prime}}{Q}+Z$.) $\times M$. 
This formula may be translated into intelligibility as follows : Richard Roe has the sum of species characters : race characters; one unequal fourth of father's peculiarities; one unequal fourth of mother's peculiarities; one sixteenth of paternal grandfather's peculiarities; one sixteenth from maternal grandfather; one sixteenth from each grandparent; one sixty-fourth from each great-grandparent, etc.; an unknown part of the gain through the father's activity; an unknown part of gain through the mother's activity; an unknown part of loss the idleness or non-development of each; an unknown chance through prenatal influences received through the mother; the whole multiplied or divided by the influences arising from transmission or early nutrition and to be modified in every part by the fact that he is a man.

But these symbols indicate only potentialities. These make up the architect's plan on which his life is to be not character.
Potentialities

built. The plan admits of much play for deviation. Every wind that blows will change it a little. These elements themselves are of varied character. They do not belong together nor are they held in place, so far as we know, by any "ego" except that made by the cell alliance on which they depend. Some of these elements the experiences of life will tend to reduce or destroy. Some of them will be systematically fostered or checked by those who determine Richard Roe's early environment. The final details will be beyond prediction. The ego or self in the life of Richard Roe is the sum of his inheritance, bound together by the resultant of the consequences of the thoughts and deeds which have been performed by him and perhaps by others also. Thus each day in his life goes to form a link in the chain which binds his conscious processes together. The 
"vanished yesterdays" are the tyrants of to-morrow. The higher heredity is the heredity from ourselves. The art of life is in a large degree the process of "holding one's self together." 'The ego is the expression of

The higher heredity. the result of this process. , Just as "England" exists only as the co-operation of all Englishmen, so does the mental "ego" exist only in the co-ordination of working nerve cells. The theory that the ego is a separate being which plays on the organs of the brain as a musician on the keys of a piano, belongs not to science but to poetry. As well think of England as a disembodied organism that plays on the hearts of Englishmen, leading them to acts of glory or of shame. This, too, might be poetry; it is not fact.

The unity of life, which is its sanity, depends on bringing the various elements to work as one force.

The unity of the ego.

Duality or plurality in life, the "leading of a double life" of any sort, is an evidence of some kind of failure or disintegration. "Science finds no ego, self, or will that can maintain itself against the past." In other words, from the past, its inheritance, and its experience, the elements of the present are always drawn. The consciousness of man is not the whole of man. It is not an entity working among materials foreign to itself. It is rather the flame that flickers over embers set on fire long before and whose burning may go on long after the individual flame has ceased to be.

"The soul," says Dr. Edward A. Ross, "is not a spiritual unit, but a treacherous compound of strange contradiction and warring elements, with traces of spent passions and vestiges of ancient sins, with echoes of forgotten deeds and survivals of vanished habits." Moreover, "science tells us of the conscious and sub- 
conscious, of higher nerve cells and lower, of double cerebrum and wayward ganglia. It hints at many voiceless beings that live out in our body their joy and pain and scarce give sign dwellers in the subcentres, with whom it may be often lies the initiative when the conscious centre itself is free. This $I$ is no doubt a hierarchy or commonwealth of physical units that at death dissolves and sinks below the threshold of consciousness." "We see that never again can there be such an orgy of the ego (in philosophic thought) as that led by Fichte and Hegel."

Of course, some of the above-quoted phraseology is figurative, and could not be applied literally to the

The ego a co-operation.

personality of Richard Roe. His selfconsciousness arose from the co-operative action of his higher nerve cells. That it arose from many, not from any particular one, gave it in some degree the semblance of being apart from them all. But this was only a semblance, and the elements of which his personality was made had been in one way used before him by many others.

With all this, we may be sure that the stream of Richard Roe's life will not rise much above its potential fountain. He will have no powers far beyond those potential in his ancestors. But who can tell what powers have remained latent in these ancestors ? It takes a series of peculiar circumstances to bring any group of qualities into general notice. These men who are famous

Fame not greatness. in spite of an unknown ancestry are not necessarily very different from this ancestry. Fame is a jutting crag which may project from a very low mountain. Far higher elevations may not catch the eye if their outline is not unusual. Even under the plebeian name by which "Fate 
tried to conceal him," Richard Roe may receive a noble heritage. Doubtless it may be passed on to the next generation, not the less noble because it has not been exposed to the distortions of fame. Real greatness is as often the expression of the wisdom of the mother as of anything the father may have been or done. $B^{\prime}$ and $\mathrm{X}^{\prime}$ are just as potent as $\mathrm{B}$ and $\mathrm{X}$, though less known to the public. As society is now constituted, the great hearts and brains of the future may be looked for anywhere. They will not fail to come when needed, and in most cases they will appear unheralded by ancestral notoriety.

I made the statement above that Richard Roe had twice as many ancestors as his father or his mother. This is self-evident, but it is not literally

Counting one's ancestors. true. The error comes from the interlocking of families. Over and over again in any line of ancestry strains of blood have crossed, and the same person, and therefore the whole of this person's ancestors, will be found in different places in the individual pedigree. This must happen dozens of times in most lines of ancestry. The lack of old records obscures this fact. That something of the sort must occur is evident from the fact that the child of to-day must have had at the time of Alfred the Great an ancestry of $870,672,000,000$ persons. In the time of William the Conqueror (thirty generations) this number reaches $8,598,094,59^{2}$. This is shown by the ordinary process of computation-two parents, four grandparents, eight great-grandparents, and so on. As the aggregate of Englishmen in Alfred's time, or even in William's, was but a very small fraction of these numbers, most of these ancestors must have been repeated many times in the calculation. Each person who leaves descendants is a link in the great chain of life, or rather a strand in life's 
great network. It is certain that the blood of each person in Alfred's time who left capable descendants is represented in every family of England of strict English descent. In other words, every Englishman is descended from Alfred the Great; as very likely also from the peasant women whose cakes Alfred is reputed to have allowed to burn. Moreover, there are few if any who do not share the blood of William the Conqueror, and most ancestral lines, if they could be traced, would go back to him by a hundred different strains. In fact, there are few families in the south and east of England who have not more Norman blood than the present royal family. The house of Guelph holds the throne not through nearness to William, but through primogeniture, a thing very different from heredity.

Mr. Edward J. Edwards, of Minneapolis, has recently sent me some very interesting studies in genealogy yet unpublished. These concern the lineage of his little daughter, my niece, Mary Stockton Edwards.

Mr. Edwards find that the little girl, like millions of others, is descended through at least two different lines from William the Conqueror. The lineLineage of a little girl. age, on the one hand, leads back in thirty-two generations through the family names of Jordan, Hawley, Waldo, Elderkin, Drake, Grenville, Courteney, de Bohun, and Plantagenet to William. Sir Humphrey de Bohun married Elizabeth Plantagenet, daughter of King Edward I. In the ancestry of King Edward are the Saxon kings Cedric, Egbert, Alfred, and Ethelred, while intermarriage with other royal lines brings in Hengest, Hugh Capet, Charlemagne, Otho the Great, Duncan, Rurik, Igor, San Fernando, and a host of other notables of whom one would have less 
right to be proud. The Courteneys, Earls of Devon, are again descended from the royal lines of France (Hugh Capet) and Russia, but not from William the Conqueror. To Courteney and Plantagenet the lineage of the Edwards family along other lines has been traced.

The seventy family names, more or less, with perhaps a thousand representatives, in the first line traced out by Mr. Edwards, are only so many out of billions, if there were no duplications. If there were no repetitions, there would be instead of the thousand known ancestors, four billions of persons between Mary Stockton Edwards and the time of William the Conqueror. This genealogy is therefore but a strand from an enormous network, which, if written out in full, would cover the earth with names. Only the family pride of the Courteneys and Drakes caused even this little of personal descent and personal history to be retained. Their pride permitted this plebeian record of the plebeian descendants of the Puritan John Drake of Windsor to be joined to the sacred annals of the English peerage.

Most of the English people named in these records lived in Devon and Sussex, from which regions the American representatives came to AmerAll Englishmen ica. The subordinate lines traced out of noble birth.

lead to the earls of these countries. They lead also to many other noble lines in England and Scotland. It is certain, however, that in this there is nothing whatever that is exceptional or even unusual. These people in America were Massachusetts Puritans, plain farmers, squires, and shipwrights, with a lineage or character in no wise singular. Their sole important heritage was the Puritan conscience, not their Norman blood, which they shared with all their neighbours. Studies of this kind show clearly that primogeniture is 
mainly responsible for the difference between Roundhead and Cavalier, between Royalist and Puritan. Roundheads and Puritans were descended from daughters and younger brothers. The "blue blood" flows only in the veins of the eldest son. But the eldest son of the eldest son forms but a very small fragment of the whole. Galton's remark to the effect that the character of England has suffered through the segregation of its strongest representatives as nobility and their exposure to the deteriorating influences of ease and unearned power is scarcely justified. A few individuals have suffered, but not England. They are only the conspicuous few. The rest have joined the mass of common men whose greatness makes England great.

One of the many daughters of some king marries a nobleman; a later scion of nobility is joined to some Effect of primogeniture. squire; some daughter of a squire is married to a farmer. The farmer's children thus have royal blood in their veins. Or, by reverse process, plebeian blood may enter-and to its advantage - the bluest of nobility. The thirty generations since William's time each contain a far and wide mixture of blood. That the descendants of these crosses are alive to-day indicates that in the main each individual has a sound heredity. For a rotten link means the breaking of the chain. Even royal blood is not necessarily degenerate. That which was so has been strengthened by plebeian strains. There can be few if any Englishmen or Americans today but have royal blood in their veins. There is probably not a king living who has not somewhere in his ancestry the bar sinister of the common peasant. For of one blood, after all, are all the nations of the earth, as well as the men that make up these nations. 
Another necessary conclusion is this, that race characteristics imply direct personal relationship among

Origin of the

English character.

those who exhibit them. The Englishmen of to-day are such because they are related by blood. They are the variously intermingled descendants of some few robust families of a thousand years ago, a hundred thousand of them at the most. "Saxon and Norman and Dane are we." From these familiesDane, Norman, and Saxon-the weak, the infertile, and the unfortunate are constantly undergoing elimination, leaving the strong and fecund to persist. The withered branches are only kept in existence through misplaced charity which continues the pauper; or through bad social conditions which propagate the criminal. Pauperism, criminality, and folly have their lineage, but it is not a long one; and wiser councils will make it shorter than it now is. This persistence of the strong shows itself in the prevalence of the leading qualities in the dominate strains. To these dominant ancestors every line of deviation will be found to lead, when we come to follow it, backward. In following the pedigree of an individual backward for a thousand years, we find that millions of duplications must occur in his ancestry. That is, thousands of persons would be reached from one to a thousand times each in the following up of different ancestral lines. The growth of colonial types comes from the narrowing of the range of crossing and from intermarriage with lines not English, which occurs most frequently outside of England. This is especially true in the United States. But in a few centuries these same conditions will unite to form a "Brother Jonathan" as definite in qualities and as "set in his ways" as his ancestor, the traditional "John Bull." 
Race types thus arise from the " survival of the existing," its best results modified and preserved by the

Race types and the survival of the existing. "survival of the fittest." Actual presence in a country of certain ancestral stocks is the first element. Their characters become workable, durable, and at last "ineradicable" by the survival of those in whom those characters are elements of life. An " unworkable" heredity destroys its possessor, and with him the line of possible descent. 
THE PHYSICAL BASIS OF HEREDITY.

By Frank Mace McFarland.

ALL living organisms, animals as well as plants, are built up of certain elementary parts or units termed The cell theory. cells. No matter how widely divergent in external appearance or habitat they may be, the elephant and the lily, the sponge and the palm, are each aggregations of structural units, fundamentally alike, and no form of animal or plant life is known to exist which does not conform to this general law. To the studies of Schleiden upon plants and of Schwann upon animals (1 $838-' 39$ ) we owe the foundation of the "cell theory," more precisely formulated by Max Schultze in $\mathbf{r} 86 \mathrm{r}$. Since the time of these pioneer studies upon the cell, investigation has been carried on by a constantly increasing number of students with methods and instruments steadily improved in their efficiency, and the accumulated results already throw a wealth of light upon some of the most abstruse problems of biology. Yet the most enthusiastic and sanguine of these workers will not assert that we have advanced further than the threshold of this domain in which are concealed the answers to the questions as to the ultimate structure of living matter and even to the very nature of life itself. 
The accumulating results of patient study have totally changed the earlier conceptions of the cell. Two and a quarter centuries ago, by the aid of the newly invented microscope, minute cavities were discovered in certain plant tissues, and from their resemblance to a honeycomb were termed "cells." This study of such substances as ordinary cork, in which the cells are dead and empty, easily led to the idea that the cell wall was the all-important feature, and it has not been until within the past forty years that this error has been set aside. The name "cell" itself is some-

The meaning of the term "cell." what misleading in that it implies, in the ordinary usage, a cavity with definite walls of considerable firmness, which is by no means always true. Great groups of cells have no solid walls whatever, but are soft and changeable in form, and the majority of cells have no cavities, but are masses of semifluid consistence. The appearance of empty cavities, or clear fluid-filled spaces, is a condition which comes about in plant cells late in life, and scarcely ever in animal ones. The unwearied study of biologists, aided by constantly improved instruments and methods of research, have shown that it is the contents of the cell which form the essential living substance. But, although the cell wall has lost the significance which it formerly was held to possess, the term cell has become firmly fixed by usage, and such terms as "Energide," as proposed by Sachs, though much more happily chosen, are very slow of adoption.

The simplest forms of life of which we know anything are minute microscopic organisms found in both fresh and salt water and under the most varied conditions. Each one of these is composed of a single cell, and each one carries out in a general way the varied functions of movement, respiration, growth and multi- 
plication, assimilation, secretion, excretion, irritability, etc., functions which, in multicellular organisms, are di-

Unicellular and multicellular organisms.

vided up among a vast number of the constituent cells. Thus while the onecelled amœba has its muscular, nervous, and digestive systems united within the limits of a single microscopic mass of protoplasm, the higher animals have their various functions divided up among definite groups of thousands and millions of cells, each group carrying out some particular function. In response to this physiological division of labour among the cells has come about a corresponding modification in their structure, so that we find certain forms and types characteristic of the particular function which the respective cells carry out. The muscle cell, for example, is one whose special work is that of contraction. Within its substance has been developed a system of highly contractile fibrils, and the whole cell has assumed an elongated shape. For this one function of contractility have been sacrificed more or less completely the other properties of protoplasm, and thus it has become dependent upon its fellows which have assumed various other functions. The bone cell, the gland cell, the epithelial cell-all have equally complicated specializations of structure in other directions and, all united together into an organic community, are co-ordinated and directed in their various activities by the nerve cells.

However diverse the form and function of the adult tissues may be, they all have the same fundamental The essential parts of the cell. structure, and they all have a common origin and descent from the fertilized egg cell. The essential parts of a cell consist of the cell body and the cell nucleus, which together make up the living substance. The body of the cell is made up principally of a granular, viscid, semi- 
fluid substance termed protoplasm or cytoplasm. By this term is understood not a homogeneous, definite The protoplasm. chemical substance, but rather an organized association of extremely complex organic compounds, belonging mainly to the group of proteids. The majority of these substances are but little understood as yet, nor is this at all surprising when we reflect that the living cell is the theater of constant changes, both synthetic and analytic, and that the dead protoplasm subjected to the chemist's analyses is no longer protoplasm, but has suffered profound transformations in passing from the living to the lifeless condition.

In its simplest form the cell is an approximately spherical, viscid, granular structure in which oftentimes there may be made out, in the living state, more solid substances in the form of threads or networks of delicate filaments. This threadwork is probably made up of rows of granules, and varies in arrangement in different cells and in different parts of the same cell. Within the meshes of this reticulum is inclosed a clearer fluidlike portion-the cytolymph or hyaloplasm.

Inclosed in the cytoplasm lies a spherical or ovoidal body-the nucleus-set off from the rest of the cell by The nucleus.

a more or less distinct boundary membrane. This structure is of constant occurrence in all cells, and plays an extremely important part in their life history, forming apparently the controlling centre of the constructive processes in growth and multiplication. Its significance will be better understood further on in connection with the problems of cell development and heredity.

In chemical and physical propetties the nucleus differs markedly from the rest of the protoplasm. When studied in detail by the aid of suitable reagents and 
magnification, it is found to consist essentially of a delicate network or system of threads, the "linin network," bearing granules of a substance rich in phosphorus, which, from its affinity for certain staining fluids, has been termed "chromatin." One or more rounded structures, behaving in certain definite ways toward reagents, may also be found in the nucleus. These, the "nucleoli," are probably not always of the same nature in different cells, and their significance is at present much less clearly understood than is the case with the other nuclear structures. Filling the meshes of the nuclear network is found a clear semi-fluid material, the "karyolymph," and a more or less clearly defined wall, the nuclear membrane, incloses the nuclear substances and separates them from the cytoplasm.

In $r 876$ Van Beneden announced the discovery of a minute rounded body at the poles of the spindle in the dividing eggs of Dicyemids, which has since been found in nearly all kinds of animal cells, both in division and in the "resting condition," and may probably be regarded as of universal occurrence, so far at least as animal cells are concerned. In plants, however, it has thus far been identified with certainty in but few forms.

The centrosome.

To this structure Boveri, in 1888 , gave the name of "centrosome," and showed it to be a cell organ of probably constant occurrence and of the greatest significance in cell multiplication. It often lies in a more or less specialized area of the cytoplasm, the "attraction sphere," or "archoplasm," near the nucleus, but in some forms it is doubtless without any such surrounding structure.

The foregoing paragraphs must be taken merely as the briefest outline of cell structure. It would far exceed the limits of this article to attempt to discuss the finer detail of the subject, or to enter upon the many 
points of interest which are still a matter of controversy.

According to many earlier observers, and especially clearly enunciated by the pioneers of the cell theory, Schleiden and Schwann, it was generally assumed that cells arose by a sort of crystallization out of an unorganized ground substance-the "cytoblastema" of Schleiden. This idea, however, was soon overthrown by the more complete observations of von Mohl, Unger, Naegeli, Remak, Kölliker, and others, and the foundation was laid for the important generalization of Virchow, "omnis cellula e cellula," which has since become one

Cell multiplication. of the most fundamental principles of biology. Every cell is derived from a pre-existing cell by a process of division, and this process has gone on unceasingly from the time when life first began down to the present moment. All life comes from pre-existing life, and, whatever may have in some past time occurred, the spontaneous production of living substance from a non-living condition does not now exist.

One of the earliest results of the study of cell multiplication was the discovery that division of the nucleus precedes the division of the cell body. Furthermore, a careful examination of the different phases of the process offers the strongest proof that the most important feature of this division, an end to which all the other processes are subsidiary, is the exact halving of a certain nuclear substance, the chromatin, between the two daughter cells which result from the division. To gain Karyokinesis. a clear conception of this process of indirect cell division, or "karyokinesis," let us consider the changes which take place in typical cell multiplication. Two parallel series of changes occur nearly simultaneously, the one affecting the nucleus, 
the other the cytoplasm. In the so-called "resting" nucleus-i. e., the nucleus not in active division-the chromatin, as we have seen, exists usually in the form of scattered granules arranged along the linin network, and does not colour readily with nuclear stains (Fig. $5, A)$. As division approaches these chromatin granules become aggregated together in certain definite areas, forming usually a convoluted thread or skein, which now readily takes up the nuclear stains which may be used. In some nuclei this skein is in the form of a single long filament, in others the chromatin is divided up from the first into a series of segments, a condition which soon follows in the case of a single filament (Fig. $5, B)$. By transverse fission the latter breaks up into a

The chromosomes. series of segments, the "chromosomes," the number of which is constant for each species of animal or plant. Thus in the common mouse there are twenty-four, in the onion sixteen, in the sea urchin eighteen, and in certain sharks thirty-six. The number may be quite small, as, for example, in Ascaris, a cylindrical parasitic worm inhabiting the alimentary canal of the horse. Here the number is either two or four, depending upon the variety examined. In other forms the number may be so large as to render counting exceedingly difficult or impossible. In all cases, however, one fact is to be especially noted -viz., the number is always an even one, a striking fact which finds its explanation in the phenomena of fertilization to be discussed later on.

While the chromatin is collecting into the form of the chromosomes the nuclear membrane has disappeared. The chromosomes soon reach their maximum staining capacity, and appear usually as a collection of rods or bands of deeply staining substance lying free in the cytoplasm (Fig. 5, C). 
While this is taking place in the nucleus, another series of changes has been gone through with by the Division of the centrosome. centrosome and the cytoplasm immediately surrounding it. We have already indicated the presence of the centrosome as a minute spherical structure lying at one side of the nucleus. This body assumes an ellipsoidal form, con-. stricts transversely into a dumbbell-shaped figure, and divides into two daughter centrosomes, which at first lie side by side but soon move apart (Fig. 5, $A$ ). Around each of them is gradually developed a stellate figure composed of a countless number of delicate fibrils radiating out in all directions from the centrosome as a centre. This "aster" or "astrosphere" is at first small in extent, but grows in size progressively as the two centres move apart, apparently being derived from a rearrangement and modification of the thread-like network of the cytoplasm under the influence of the centrosomes (Fig. 5, $B$ and $C$ ).

Between these two asters, which lie a short distance apart and at one side of the nucleus, a spindle-shaped The spindle. system of delicate fibrils may often be made out, stretching from the centre of one aster to that of the other. This fusiform figure is termed the "central spindle" (Fig. 5,D). The two asters, together with the central spindle, form what is termed the "amphiaster" or the "achromatic" portion of the karyokinetic figure. The two series of changes in nucleus and cytoplasm, which have thus far gone on apparently independently of each other, now become closely interrelated in that, as the nuclear membrane disappears, a system of fibrils grows out from each astrosphere which attach themselves to the individual chromosomes (Fig. 5, D). These "mantle fibres" insert themselves along the chromosomes in such a way that 

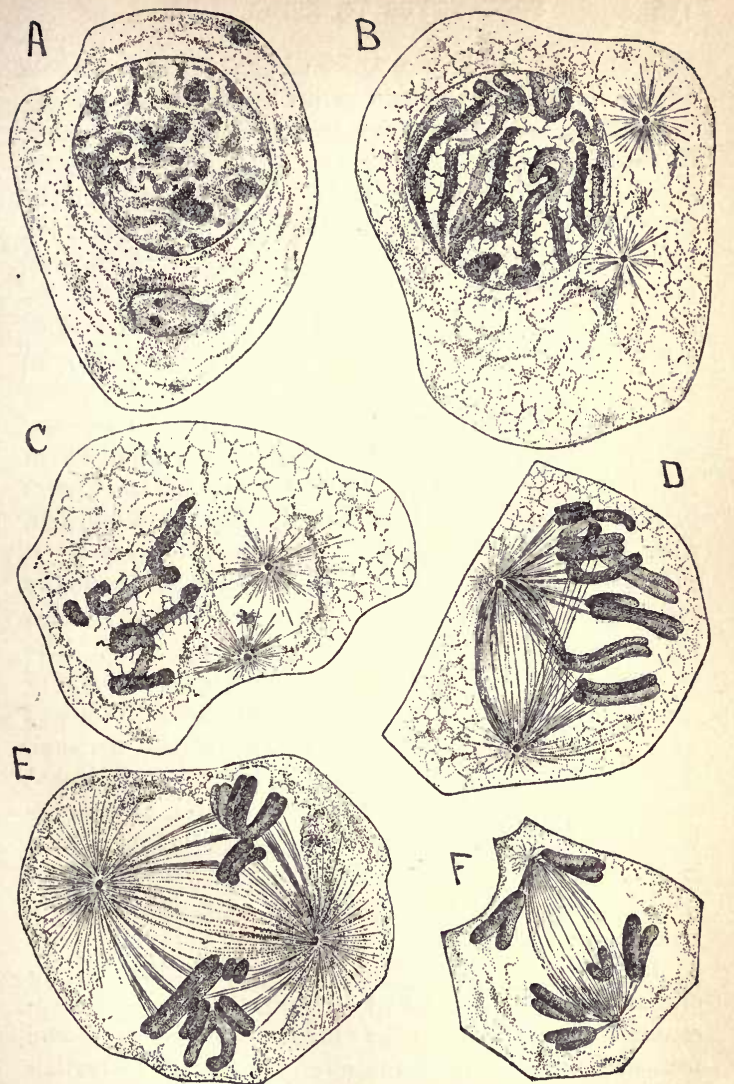

FIG. 5.-Cell division in the Salamander. (After Drüner.)

A, resting nucleus stage, centrosome below divided. B, skein stage, the chromatin visible as a convoluted band; the daughter centrosomes have separated. $\mathrm{C}$, the nuclear membrane has disappeared, a few of the chromosomes lying free in the cytoplasm. D, central spindle complete, the chromosomes, already splitting, are being drawn to the spindie. E, metaphase. F, anaphase. The chromosomes are drawn to the poles. 
each segment receives a series of fibrils from each pole of the amphiaster, the two series being attached along opposite sides of the chromosomes. Under the influence of these fibres, probably by direct pulling, the chromosomes, now bent into $\mathrm{V}$ - or U-shaped loops, tend to place themselves in a circle around the centre of the spindle, transversely to its long axis, and form the "equatorial plate" (Fig. 5, E).

The changes thus far constitute the "prophases" of the division. The "metaphases" following these conSplitting of the chromosomes. sist primarily in the longitudinal splitting of each chromosome and the moving apart of the halves. This longitudinal splitting of the chromosome into two equivalent parts forms the most important act of the whole cell division, and is of the greatest theoretical significance. By it the chromatin substance of the original nucleus is equally distributed between the two daughter nuclei, so that each receives a half of each original chromosome. The elaborate mechanism and consequent expenditure of energy involved in this careful longitudinal division of each chromosome, rather than a simple mass division, such as might be brought about by far less complicated means, indicates clearly that the distribution of the definite organization of the chromatin to the daughter cells is of primary importance, a conclusion which is further strengthened by much evidence too extended to be entered upon here.

In the "anaphases" and "telophases," which include the closing stages of division, the daughter chromosomes migrate along the fibres of the central spindle toward its poles, perhaps through the direct contraction of the mantle fibres under the influence of the centrosome, though this and many other points regarding the forces at work must be left for future investigation 
to decide (Fig. 5, F). Arrived at the poles the Vshaped chromosomes become grouped in a star-shaped figure, the "aster," their outer ends become again joined together in the form of a tangled skein, the individual chromatin granules separate somewhat along the threads of the linin network, their deeply staining quality is decreased, and a new nuclear membrane develops around each group of chromosomes. Simultaneously with this the cytoplasm constricts across the middle of a somewhat elongated cell, resulting in complete division in the equatorial plane of the spindle, and two separate daughter cells result. Each of these is made up of cytoplasm containing a centrosome and a nucleus, similar in all respects to the parent cell from which it has arisen.

A simple tabulation of the changes just described is as follows :

Phases of Cell Division by Karyokinesis.

I. Prophases..... $\left\{\begin{array}{l}\text { I. Resting nucleus. } \\ \text { 2. Skein stage of chromatin. } \\ \text { 3. Segmented skein. }\end{array}\right.$

II. Metaphase.... $\begin{array}{r}4 . \text { Equatorial plate and splitting of } \\ \text { chromosomes. }\end{array}$ III. Anaphases.... $\begin{array}{r}\text { 5. Movement of chromosomes to poles } \\ \text { and formation of } \\ 6 \text {. Segmented daughter skeins. }\end{array}$ IV. Telophases.... $\left\{\begin{array}{l}\text { 7. Reconstruction of nucleus. } \\ 8 \text {. Division of cytoplasm. }\end{array}\right.$

It is readily seen that the culmination of the process lies in the splitting of the chromosomes and the separation of their component halves to form the two new daughter nuclei.

In the foregoing description of the changes typically passed through by an animal cell in division, 
no attempt has been made even to indicate the many variations in detail which occur in different animals and plants. These are numerous, but do not affect the general plan nor the fundamental goal, which is always and invariably the same-viz., the equal, longitudinal division of the chromosomes or the chromatin band of the parent nucleus between the two daughter nuclei.

Another method of cell division, formerly taken to be the universal one, has since been shown to occur "Direct" division. solely as a stage in the degenerative changes of cells which are upon the downward road to disintegration, and in which the power of multiplication is about at an end. In this, the "direct" or "amitotic" form of cell division, the cell nucleus is simply constricted into two portions preceding the constriction of the cytoplasm. This method stands in marked contrast to the elaborate mechanism which insures the exact distribution of the nuclear substance in the karyokinetic or indirect method.

Every multicellular organism arises by a process of division from a single cell, the fertilized germ or egg cell, which in turn has been cut off from the cells of a pre-existing individual. Out of the group of cells which result from the continued division of the germ cell and its descendants are differentiated the various tissues and organs of the body through which the vital functions are carried on. Those tissues and organs which perform functions pertaining directly to the existence of the individual have been termed "somatic," and "Somatic" and reproductive tissues. their constituent cells the "somatic" or body cells, in contradistinction to the reproductive tissues or cells whose function concerns the continuance of the species. In some forms these two groups of cells, the somatic and the 
reproductive, become isolated from each other quite early in development; in one case, indeed, the differentiation of reproductive cells from the somatic ones has been traced by Boveri back to the first division of the egg. This case of Ascaris megalocephala is so striking and of such fundamental theoretical importance that it must not be passed without notice, for in it we find marked differences between the somatic and reproductive cells in their nuclear structure, their relative amount of chromatin, and mode of division. The egg of Ascaris has been the classical object for cytological studies on account of its small number of chromosomes (two in variety univalens, four in bivalens), their large size, and the diagrammatic clearness of the changes which take place in division. In the division of the fertilized egg cell we have two (in univalens) long chromosomes handed over to each daughter cell. As these two cells in Differentiation of turn divide, a striking difference is seen reproductive and somatic tissues in Ascaris.

in the karyokinetic figures. In Fig. 6, $A$, such a two-celled stage is seen from the pole; in Fig. $6, B$, a slightly later stage in side view of the spindle. In the upper cell of Fig. 6, $A$, the division is of the usual form, the two chromosomes split longitudinally, and their two halves travel to opposite poles of the spindle (Fig. 6, B). But in the lower cell this is not the case. The central portion of the two chromosomes is broken up into a large number of minute chromatin granules which divide, and, as shown in Fig. $6, B$, form the only portion of the chromosomes drawn up to the poles and entering into the structure of the resting nuclei after the division is complete. The large swollen outer ends of the chromosomes are cast off into the cytoplasm and are eventually absorbed, playing no further part as nuclear structures. Fig. 6, $C$, shows the four-celled stage, in which a marked 
difference in the size of the nuclei of the upper and lower cells is visible. Lying near the margins of the lower
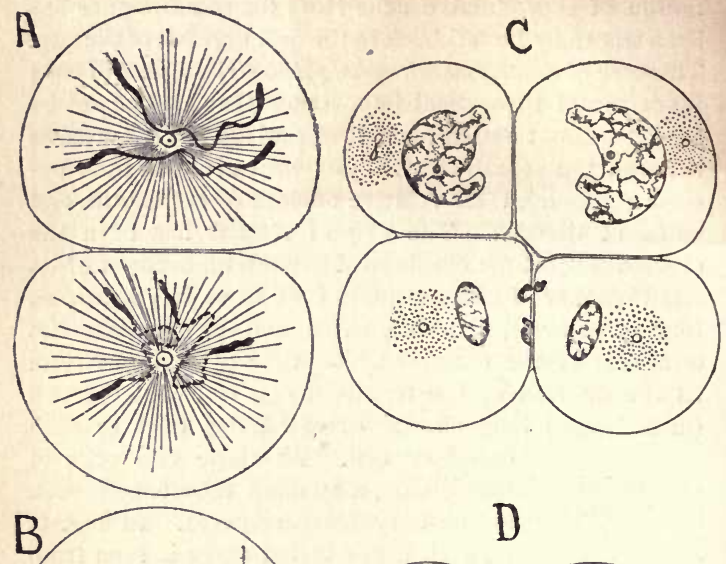

D
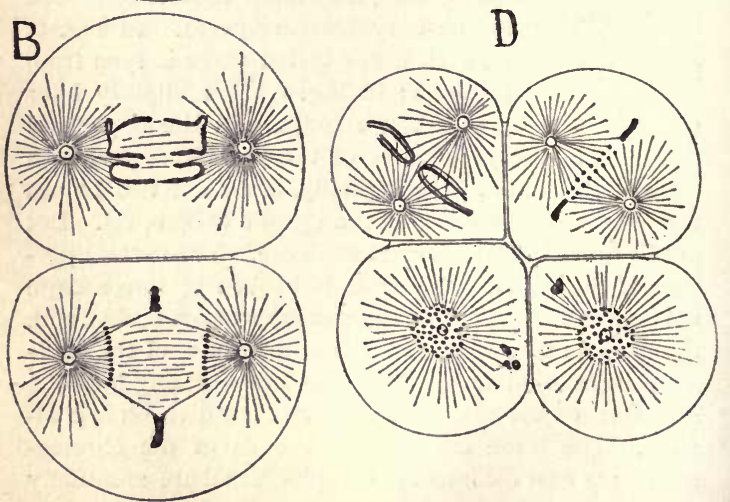

Fig. 6.-Reduction of the chromatin in the cleavage of the egg of Ascaris megalocephala var. univalens. (After Boveri.) 
cells are the remnants of the ends of the chromosomes which have been cast off in the division. In Fig. $6, D$, the four-celled stage is shown with the karyokinetic figures of the next division. In the lower cells the spindles are seen from the pole, the chromatin is present in the reduced amount in the form of small granules. In the upper left-hand cell the two full chromosomes are seen, each split longitudinally, while the upper righthand cell shows a repetition of the reduction phenomenon -viz., the central portion of the two chromosomes, broken up into granules, alone enters into the spindle figure, the outer ends being cast off into the cytoplasm, where they suffer a similar fate to those of the lower cell in the previous division. The next division repeats the process, one cell retaining two full chromosomes, while all the others have the reduced amount. This takes place for five successive divisions and then ceases; from the one cell having the two full chromosomes, the reproductive tissues develop, the others with reduced chromatin form the somatic tissues. Thus is accomplished a visible structural differentiation of the nuclei of the reproductive cells which distinguishes them sharply from all the somatic tissues in Ascaris. We shall see further on that there is abundant evidence in favour of the theory that the nucleus-i. e., the chromatin-is the bearer of hereditary influences from one generation to the next, and that the specific development and functions of each individual cell are dependent upon the specific changes which take place in the chromatin of its nucleus. In this light the almost isolated case of Ascaris possesses a value and interest that can not be overestimated.

While in the higher forms of animals and plants we find a sharp differentiation of their tissues into somatic and reproductive or germ cells, we must bear in mind 
that not in all forms is this power of the reproduction of the whole organism so sharply limited to the germ cells alone. The familiar propagation of plants by cuttings, the regeneration of complete animals from small portions of their somatic tissues in many lower forms, and numerous other considerations such as these, show clearly that the difference between the powers of somatic and germinal cells is but one of degree; that while in higher organisms the two seem sharply defined from each other, a series of lower forms may be taken which will show the intermediate steps in this gradual specialization of function.

In the unicellular organisms we have most interesting examples of the fundamental facts of reproduction,

Reproduction in Protozoa. and through an examination of these we may, gain an insight into the more complicated processes of the Metazoa. Each of these lowest forms consists of a single cell in which are carried out in a generalized way the complex physiological functions which, in many celled animals, are divided up among cell groups. In reproduction the animal simply divides into two, the division of the nucleus preceding that of the cytoplasm, and the method is usually a more or less modified karyokinetic one. This mode of multiplication continues in most forms for a certain number of generations, and then the necessity for conjugation-i. e., a temporary or permanent fusion with another individual-sets in. If this

Conjugation.

conjugation be prevented, the animal soon shows increasing signs of degeneration which result in death. This "senescence" of the powers of growth and multiplication can only be checked by the admixture of new nuclear substances from an entirely different individual by conjugation. In its simplest terms this process is found in Chilodon, 
according to Henneguy. Chilodon is a minute freshwater infusorian, which multiplies for a considerable period of time by transverse division. After a time, however, the physiological necessity for conjugation ensues. The animals having placed themselves side by side in pairs and partly fused together, the nucleus of each individual divides into two portions, one of which passes from each infusor into the other to unite with the half remaining stationary. The two then separate, each having received a half of the nucleus of the other. After thus trading experiences, as it might be termed, a period of renewed vigour and activity for each sets in, manifested in rapid growth and multiplication by division, producing a large number of generations, which continues until weakening vital activities indicate the periodically recurring necessity for conjugation. In general, among the Infusoria we find the same process taking place in regular cyclical order, with more or less complicated variations of the phenomena just outlined for Chilodon. In all of them the aim of the conjugation is the same, the exchange of a certain amount of nuclear substance between the two conjugating individuals, and the same physiological effect is reached, a rejuvenescence, as it were, of the two organisms which manifests itself in renewed vigour of growth and multiplication.

In some of the lowest forms of unicellular life-for example, the Schizomycetes or bacteria and their allies -this necessity for conjugation does not appear to exist, but for the vast majority of forms this cyclical law of development holds good. In the Protozoa no division into somatic and germinal cells is found, both functions being united in the one cell which forms the whole body of the organism. In the Metazoa, however, this differentiation has taken place; the germinal cells are set apart for the preservation of the race; the so- 
matic cells carry on their various functions for a time, grow old, die, and disappear, certain of the germ cells alone surviving in the production of new individuals. On the borderland between the unicellular and the multicellular organisms, however, stand certain colonial forms, which show an exquisitely graded series of steps, from the conditions of unicellular multiplication to those of the multicellular forms. Let us examine a few examples of these. Pandorina morum is a minute

Gradual differentiation of reductive cells.

fresh-water Alga, consisting of a colony of sixteen ovoid cells imbedded in a spherical mass of a jelly-like substance. From each of these cells two long, hairlike flagellæ extend out freely into the water, and by their lashing to and fro the colony is propelled from place to place (Fig. 7, $A$ ). In multiplication by simple division each one of these cells divides into a group of sixteen daughter cells, the general gelatinous intercellular substance of the parent colony dissolves, the sixteen daughter colonies become free, and by continuous growth soon attain the size of the parent colony (Fig. 7, B). After a certain number of generations produced in this manner, the necessity for reproduction by conjugation ensues. In this method the sixteen cells of a colony divide, each one usually into eight minute cells, which are set free in the water by the dissolution of the common gelatinous envelope (Fig. 7, C). Each one of these swarm spores, or "zoospores," consists of an oval, greenish cell, the pointed end of which is hyaline and bears two long cilia, by means of which the spore swims through the water (Fig. 7, $K$ ). These zoospores are not all of exactly the same size, but no great difference is noticeable. If the zoospores from two different colonies come near each other, they unite in pairs made up of individuals of the same or of different 
sizes (Fig. 7, D). These coalesce, round up into a spherical cell (Fig. 7, $E, F$ ), which soon develops an enveloping cellulose wall, and passes as a "zygote" into a resting stage (Fig. $7, G$ ). In this condition the organism

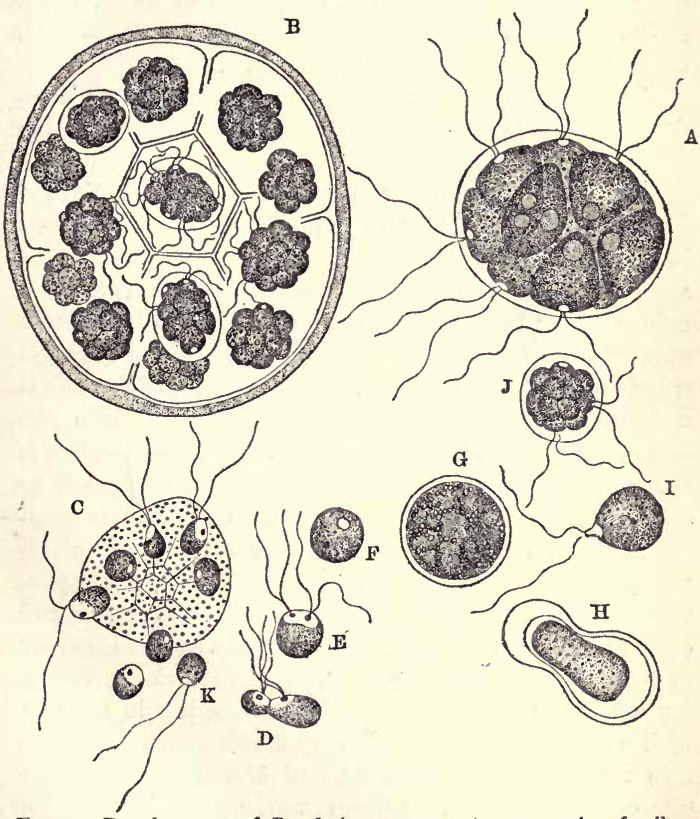

FIG. 7.-Development of Pandorina morum: A, a swarming family : $\mathrm{B}$, a similar family divided into sixteen daughter families ; $\mathrm{C}$, a sexual family, the individual cells of which are escaping from the common gelatinous investment; D, E, conjugation of pairs of swarm spores ; F, a young zygote ; $\mathrm{G}$, a mature zygote ; $\mathrm{H}$, transformation of the contents of a zygote into a large swarm cell; $I$, the same, free ; J, a young family developed from the latter; $\mathrm{K}$, a free swimming swarm spore. (After Pringsheim.) 
may remain dormant for a long time, thus tiding over a period of drouth, the winter months, etc. After this resting period, if brought under suitable conditions of moisture, the outer wall of the zygote ruptures, the contents escape in the form of a large swarm spore, which swims about for a time and then divides into the sixteen cells of a new colony (Fig. $7, H, I, J$ ).

In Eudorina elegans, a form closely related to Pandorina, there is a striking difference in the size of the Reproduction in Eudorina. conjugating zoospores. In this form sixteen or thirty-two cells are imbedded together in a common spherical gelatinous mass. The asexual mode of reproduction is the same as in Pandorina, just described, each cell of a colony being transformed by successive divisions into a new colony of sixteen or thirty-two cells which becomes free from the parent colony. The sexual mode presents a difference in that the colonies differentiate into two sorts termed male and female. In the female colonies the cells become transformed into spherical egg cells or oospheres without further division. In the male colonies, however, each cell divides into sixteen or thirtytwo antherozooids, minute, elongated cells, each provided with two long cilia projecting from its anterior end (Fig. 8, $A, B, C$ ). These remain slightly united together in bundles and, escaping from the parent colony, swarm for a time in the water together. Coming in contact with a colony of oospheres, they break apart, penetrate into the gelatinous envelope, and find their way to the egg cells (Fig. 8,D). A single antherozooid fuses with each egg cell, and the conjugated pair form a resting zygote around which a cellulose wall forms, and from which, after a certain period of time, a new colony of sixteen or thirty-two cells develops.

A third stage in the differentiation of the conjugating 
reproductive cells is found in Volvox globator. This form consists of a hollow spherical colony of as many as

Volvox.

twenty-two thousand cells placed in a single layer in a hyaline jelly-like substance, and connected with each other by cytoplasmic processes. Each one of the cells is a somewhat ovoid

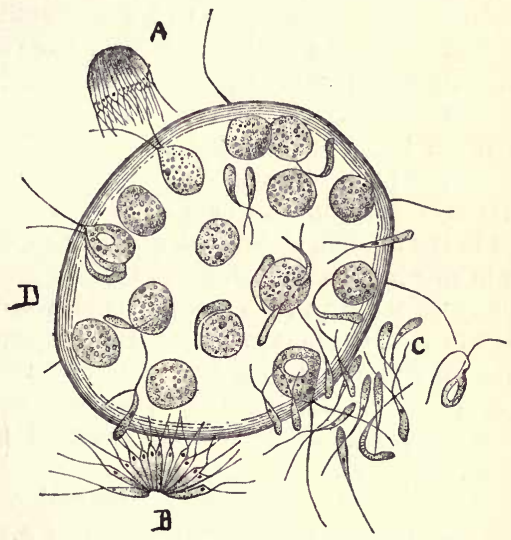

FIG. 8.-Eudorina elegans, a female colony around which antherozooids are swarming: A, cluster of antherozooids still united; B, cluster of antherozooids just separating; C, swarming antherozooids, some of which have already penetrated into the female colony D. (After Goebel.)

mass of green-coloured protoplasm, and bears two long cilia upon its outer, pointed, hyaline end which project out into the water and, lashing to and fro, give to the whole colony a rotary motion. At the time of reproduction, certain cells of the colony undergo profound modifications. Some of them increase in size enormously, having reserve food material stored up in them, and become the egg cells or oospheres. Other cells divide 
into bundles of minute antherozooids (sixty-four to a hundred and twenty-eight). The remaining cells of the colony, remain in a vegetative condition, and eventually die. In reproduction, one of the antherozooids fuses with one of the oospheres, a resting zygote is formed from which develops later a new colony. Thus in the Volvox colony we meet with a differentiation into somatic or vegetative cells and reproductive cells, a differentiation which persists through all the multicellular plants and animals.

A much larger series of forms might be cited to illustrate the phenomena of multiplication among unicellular organisms, which would show all stages of gradation in the relative size of the conjugating cells from those in which both are of equal size and are equally active, to such forms as Volvox, in which a great difference in size exists, the larger, the oosphere, being non-motile and laden with food material, the smaller, the antherozooid, having the cytoplasm reduced to a very small amount and being endowed with high mobility.

In multicellular organisms we meet with a continuation of the same facts. The animal egg is a single cell laden with a large amount of food yolk, Reproduction in and made up of nucleus and cytoplasm Metazoa.

as the living elements. For the development of this egg, conjugation with another germ cell, derived from a different individual, is necessary. This germ cell is the spermatozooid, a minute cell consisting of nucleus and centrosome with a small amount of cytoplasm modified primarily into an organ of locomotion, the tail. A physiological division of labour is here met with which admirably meets two diametrically opposed requirements. The one of these demands that the conjugating cells be highly motile, and consequently small, 
in order that they may be able to come together in the water in which they are usually set free. The second requires that there be furnished a sufficient amount of nutritive material for the nourishment of the embryo until it arrives at a stage of growth in which it can shift for itself. These two necessities have been met by a physiological division of labour between the two conjugating cells. The one, the sperm cell, has become reduced in size with a corresponding gain in motility, the other, the egg cell, has had food yolk stored up in it, and its consequent increased size prevents any more than a very slight degree of independent movement, if any. Different stages of these modifications may be met with among unicellular forms, as illustrated above in Pandorina, Eudorina, and Volvox, to which might be added many others. In Pandorina the conjugating cells are of nearly equal size, in Eudorina an intermediate condition is reached, while in Volvox the egg and sperm cells are sharply differentiated in size and motility. Again, in the first two and their allies all of the cells are at first vegetative and afterward reproductive, while in Volvox the definite separation into vegetative or somatic, and reproductive or germinal cells makes its appearance.

We arrive then at the conclusion, from the consideration of these and many other lines of evidence, that the

Fundamental identity of the germ cells. germ cells were primitively exactly alike, and that the differences between them have arisen in the process of differentiation along two separate lines. Furthermore, it is clear that the differences between the two sexes, which become strongly characterized in the higher vertebrates, are all of a purely secondary nature.

In their early development the germ cells are indistinguishable from each other, and both pass through 
certain stages preliminary to their union, which are essentially alike. The animal egg is a large, more or The egg cell. less spherical cell, enveloped usually by certain membranes, containing a large nucleus and cytoplasm. The vast bulk of the egg cell, however, is made up of inert food material in the form of yolk granules, which are stored up in it as nourishment for the developing embryo. The nucleus, or germinal vesicle, is large, and contains a network of chromatin together with one or more conspicuous nucleoli. There are three periods usually recognised in the development of the egg cell, viz.: r. The period of multiplication; 2, the period of growth; and, 3, the period of maturation. The first period is characterized by a continued series of divisions of the primitive reproductive cell and its descendants, which produces a large number of "ovogonia." Succeeding this is a period of growth in which the ovogonia increase greatly in size, mainly through the production and storing up of food yolk. At the close of this period the germ cell, now termed a "primary ovocyte," enters upon the maturation period, in which it undergoes two divisions in rapid Maturation. succession, by means of which two minute cells, the polar bodies, are cut off from the egg. Through these two divisions the number of chromosomes in the egg nucleus is reduced to one half that which is found in the other cells of the body. The first polar body. also usually divides, and thus, at the close of the period of maturation, four cells result, one large mature egg cell, ready for the fertilization which initiates the development of the embryo, and three minute polar bodies, which are to be regarded simply as rudimentary eggs. The nuclei of these four cells are exactly alike in that they all contain the same number of chromosomes-i. e., one half the number in the somatic 
cells of the individual. The difference in size is due simply to the concentration of the food yolk and most of the cytoplasm in one of the cells, the other three degenerating, being sacrificed to the production of an egg cell with the largest possible supply of nutritive substance in it.

Turning to the development of the sperm cell we find an exactly parallel series of stages, the end results, howThe sperm cell. ever, differing much in size. The mature cell, consisting typically of a cylindrical or conical "head" containing a nucleus, a short cytoplasmic "middle piece," and a long vibratile "tail," an organ of locomotion differentiated out of the cytoplasm of the cell from which the spermatozoon is derived. The stages of multiplication, growth, and maturation are passed through in the development of the spermatozoon in the same order as in the egg development, save that the period of growth does not include the storage of food yolk in the primary spermatocyte, and the two divisions of the maturation stages are equal ones, resulting in the production of four cells of the same size, each of which develops into a complete spermatozoon. The accompanying diagrams of Fig. 9, taken from Boveri, illustrate clearly the homologies existing between the life histories of the two sorts of germ cells. The earlier stages of ovogonia and spermatogonia are indistinguishable from each other; later in the period of growth the increase in the size of the ovocyte marks it off from the minute spermatocyte, but this distinction is merely one due to non-living food material, and in no wise affects the fundamental identity of the two. In the maturation period the number of chromosomes in the nuclei of both egg and sperm is reduced one half-on the one hand, the ripe egg cell and three rudimentary egg cells (the polar 
bodies) being formed; on the other, four equal "spermatids" are produced, which develop into four mature
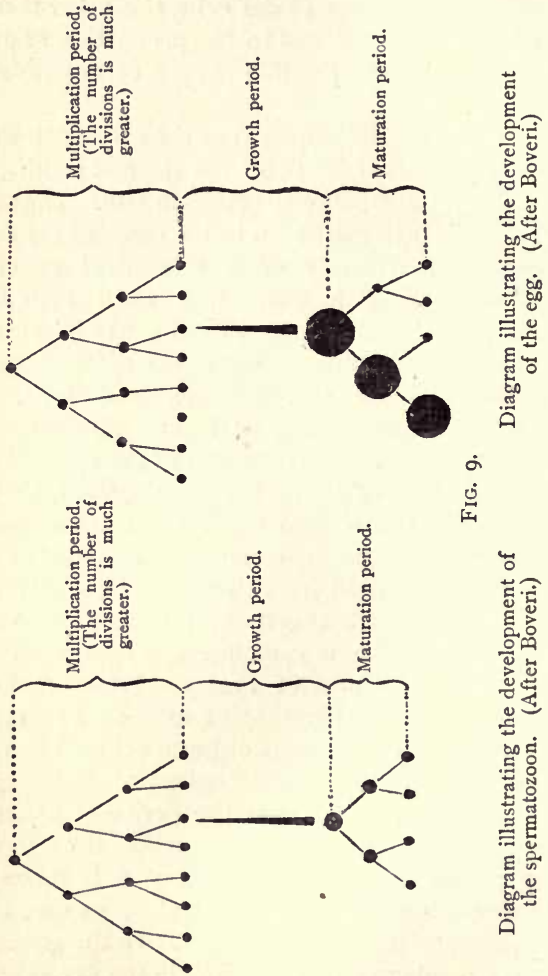

फ

岂.

ํํㅇ

ङ

它

.

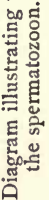

spermatozoa. The contrast in size which exists between the two mature reproductive cells is enormous, the 
spermatozoon in some cases containing less than $\frac{1}{100000}$ (Wilson), and in extreme cases less than $\frac{10000000}{1}$ (Hertwig) of the volume of the egg cell.

A discussion of the method by which the reduction of the chromosomes in the germ nuclei is brought about Fertilization. may profitably be deferred until the essential features of fertilization have been examined. The phenomena of the fusion of egg and sperm can best be studied in some such form as the sea urchin, in which the egg is very small and, in some species, quite transparent. As fertilization takes place free in the sea water, the germinal cells being cast out from the parents, it is possible to collect the eggs and sperm separately from mature individuals and bring them together in small dishes of sea water, and at such times as may suit one's convenience. Then in the living egg much of the process may be followed under the microscope, and properly prepared sections of the eggs killed by reagents at the various stages enable conclusions to be drawn as to matters of minute detail. Fig. ro, $A$ to $F$, presents a series of diagrams, taken from Boveri, illustrating the principal facts in the process of fertilization. In Fig. Io, $A$, the egg is represented with its clear nucleus in the centre, surrounded by the egg membrane. Clustered around the periphery are a number of spermatozoa endeavouring to find their way into the substance of the egg. On the right-hand side in the figure one has penetrated the membrane and is shown passing into the egg cytoplasm, which puts forth a small conical prominence to meet it. As soon as the head of one sperm enters the egg cytoplasm a new membrane is formed around the egg which effectually prevents the entrance of any others. The head and middle piece penetrate into the egg, the tail usually remaining imbedded in the membrane where it soon de- 

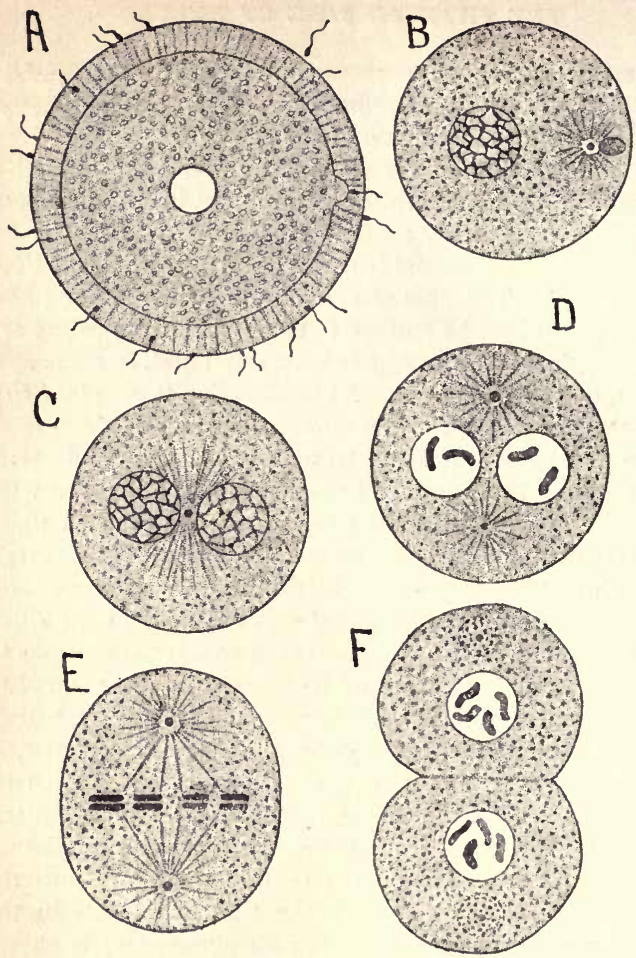

FIG. I0.-Diagrams illustrating the fertilization of the egg.

A, egg surrounded by spermatozoa; on the right, one has just penetrated the egg membranes and is entering the egg cytoplasm egg nucleus in the centre. B, egg nucleus with chromatin reticulum on left; on right, the sperm nucleus preceded by its centrosome and attraction sphere. $C_{\text {, egg nucleus on the left, sperm nucleus on }}$ the right of the centre of the egg; stage immediately preceding the division of the centrosome. D, the centrosome has divided, the two attraction spheres separate to form the first cleavage spindle: the chromosomes of the egg and sperm nuclei clearly visible and indistinguishable (in the figure the egg chromosomes are black, the sperm chromosomes shaded). E, the first cleavage spindle, with splitting of chromosomes. F, completion of first cleavage; two-celled stage, each nucleus contains four chromo: somes-two from the egg and two from the sperm. (After Boveri.) 
generates. A few moments after the sperm has entered a system of radiations appears around the middle piece, which develops into an aster surrounding the centrosome of the sperm (Fig. Iо, $B$ ). The sperm nucleus swells up and rapidly increases in size, its chromatin changing from the compact condition in which it is arranged in the sperm head to a reticulate condition (Fig. ro, $C$ ). The chromatin reticulum of the egg nucleus becomes also more clearly visible. Sperm aster and sperm nucleus now move in toward the egg nucleus, the aster usually preceding. As the nuclei approach the sperm nucleus increases still more in size until it becomes indistinguishable from the egg nucleus (Fig. 1o, $C$ ). The chromatin network of each now breaks up into a number of chromosomes, one half of the number found in the somatic cells, and the nuclei come into contact, fusing together in some cases. In the sea urchin, Echinus, the number of chromosomes is eighteen, nine would therefore be found in the germ nuclei; for the sake of clearpess and simplicity but two are represented in the diagram, those of the sperm nucleus being slightly shaded while those of the egg nucleus are black. The centroCleavage.

some divides together with its aster (Fig. ro, $D$ ), the two daughter centrosomes move apart to opposite poles of the egg, and the typical amphaster of cell division is formed (Fig. ro, $E$ ), the nuclear membranes disappearing and the chromosomes being drawn together into the equatorial plate where each splits longitudinally. The halves are drawn by the mantle fibrils toward the opposite poles and the egg divides transversely into two cells (Fig. Io, $F$ ). This process of division is repeated continuously in each of the resulting generations of cells, and from the mass of cells thus formed develops the new organism. Each cell in the two-celled stage has received half of its 
chromosomes from the egg nucleus and half from the sperm, thus containing equal amounts from each parent. The centrosome, which, as we have seen, is to be regarded as the dynamic centre of the cell division, comes from the spermatozoon alone; the egg, on the other hand, furnishes the yolk and practically all of the cytoplasm.

After this preliminary outline of the facts of fertilization we are in a better position to understand the details

The reduction of the chromosomes. of a process which occurs in the develop. ment of both egg and sperm cells, namely, the reduction of the chromosomes. The necessity for such a reduction is evident from a moment's reflection. We have seen that the number of chromosomes in the nucleus is a constant and typical one for each animal and plant species so far as known. As fertilization consists in the union of two cells into one, from which the young organism develops, it is plain that, were there no reduction, the number of chromosomes would be doubled in each succeeding generation. However simple this necessity for reduction may appear, the minutiæ of the processes through which it is brought about, and the theoretical significance of these facts, form the most involved problem of biology to-day. In a few forms, especially among the lower Crustacea, the facts of the reduction are clear and relatively simple; in other forms they thus far stand in direct contradiction, and, for the present, a comprehensive explanation applicable to all forms must be left to further investigation.

The significance of reduction turns upon the conception of a definite organization and individuality in the chromosomes and the assumption that they represent the physical basis of heredity-i. e., that they influence and determine into what the fertilized egg shall develop. 
Fifteen years ago Wilhelm Roux showed with convincing clearness that the complicated facts of nuclear division, the careful longitudinal halving of the chromatin thread and its equal distribution between the Theories as to structure and significance of the chromosomes. two daughter cells, can only be explained on the basis that the chromosomes possess different structure in different parts of their extent, and that these structures, representing tendencies in development, are distributed in definite ways to the daughter cells. Were this not the case a simple direct mass division of nucleus and cytoplasm instead of the complicated process of Karyokinesis with its consequent much greater expenditure of energy would serve all purposes.

The theories of Weismann are all based upon an extension of Roux's ideas. Briefly, he assumes a definite architecture of the chromatin filament, each nuclear rod or idant being composed of a number of "ancestral germ plasms or ids, the vital units of the third order. Each id in the germ plasm is built up of thousands or hundreds of thousands of determinants, the vital units of the second order, which in turn are composed of the actual bearers of vitality or biophors, the ultimate vital units. The biophors are of various kinds, and each kind corresponds to a different part of a cell; they are therefore the bearers of the characters or qualities of cells. Various but perfectly definite numbers and combinations of these form the determinants, each of which is the primary constituent of a particular cell, or of a small or even large group of cellse. g., blood corpuscles."

"These determinants control the cell by breaking up into biophors, which migrate into the cell body through the pores of the nuclear membrane, multiply there, arrange themselves according to the forces within them, 
and determine the histological structure of the cell. But they only do so after a certain definitely prescribed period of development, during which they reach the cell which they have to control." (Weismann, The Germ Plasm, pp. 75, 76.)

Cell division, then, is a process of qualitative analysis through which the determinants, in virtue of possessing

The ultimate vital units. a certain definite location in the architecture of the chromosome, are distributed ultimately to that portion of the body which they are to direct. Weismann has developed this theory to a most elaborate degree of complication in explaining the various phenomena of heredity -to a degree, it need hardly be remarked, which passes far beyond our present knowledge of the facts of cytology. Just as the chemist and physicist, however, are forced to the assumption of the existence of ultimate atoms and molecules to explain the phenomena of nonliving matter, so the biologist must in some form or other assume the reality of ultimate self-propagating vital units, be they called "biophors" with Weismann, "micellæ" with Nægeli, "pangenes" with De Vries, "plasomes" with Wiesner, or "physiological units" with Herbert Spencer

In the light of this probable individuality and morphological organization of the chromosomes the method Significance of of their reduction in number, preparatory reduction.

to the fusion of the germ cells, becomes of the greatest significance; to those who may deny this individuality and definite architecture, the phenomena can have no great importance save as concerns a general mass reduction in the amount of the chromatin present in the germ nuclei. It may be assumed as true, in the majority of cases now accurately known, that the reduction takes place somewhere 
in or near the last two divisions of the germ cells previous to their fusion-that is, in the egg-in the divisions forming the polar bodies, and in the sperm, in the last two divisions of the spermatocyte which produce the four spermatids out of which develop as many mature spermatozoa. The phenomena are exactly homologous in both cases, as has already been pointed out, differing only in the minor details which do not affect the end result. Two peculiar features mark these divisions off from all the others which precede and follow them. One of these is the absence of an intermediate resting stage between them, the second division following immediately upon the first without the reconstitution of the chromosomes into the skein stages. The second peculiarity lies in the fact that the chromatin masses (not the individual chromosomes) appear in one half the typical number of the chromosomes in the first division, and are usually arranged in "tetrads," or groups of four rounded, deeply staining bodies connected by linin fibres. These tetrads are always one half the number of the original rod or thread-like chromosomes.

Reduction in Ascaris.

Thus in Fig. II, $A$ represents a spermatogonium nucleus of Ascaris with the four chromosomes, showing the longitudinal splitting preparatory to division. Fig. I $1, B$, represents an early spindle stage in the division of the primary spermatocyte, in which not four band-like chromosomes, but two tetrads, or chromatin groups of four rounded bodies are found. Fig. II, $C$ to $F$, show clearly the further steps in the spermatogenesis. In Fig. I I, $C$, the tetrads are grouped in the equatorial plate, and in Fig. II, $D$, in the closing stages of the first division in to two spermatocytes, each tetrad has divided into two "dyads," which are drawn to the poles, and the division of the cell body follows. Without an interven- 
ing resting stage each spermatocyte now divided again, as in Fig. I I, $E$ and $F$, each dyad now being separated into halves, so that in the spermatids of Fig. I I, $F$, but

A
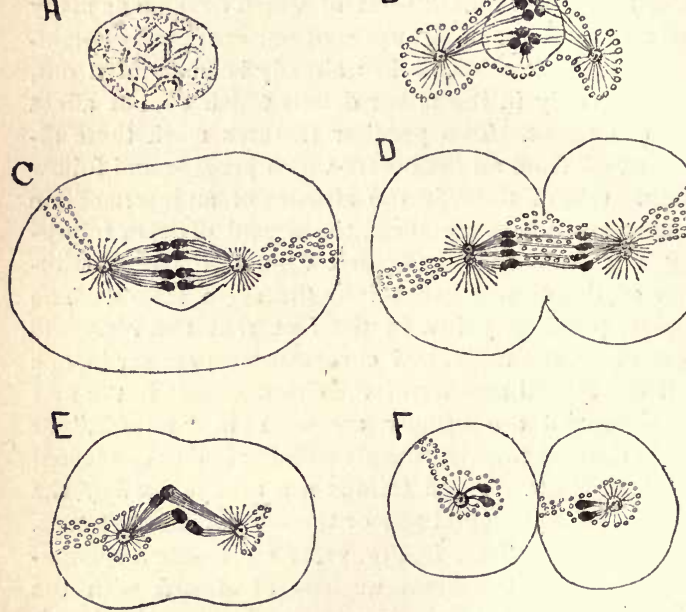

Fig. II.-Reduction of chromosomes in the spermatogenesis of $A$ scaris megalocephala, var. bivalens: A, nucleus of a spermatogonium; the typical number of chromosomes (four) is seen, each split longitudinally preparatory to the next division. B, young spindle stage of primary spermatocyte; two tetrads are present, each formed by the double longitudinal splitting of a chromatin thread. C, the tetrads in the equatorial stage of the division. D, separation of dyads. $\mathbf{E}$, the dyads in the succeeding division of the secondary spermatocyte. F, completion of the division of the same; each cell (spermatid) contains the reduced number of chromosomes (two). (After Brauer.)

two chromatin masses are present. Thus the tetrads of the primary spermatocyte are divided up among the four spermatids, so that each of the latter receives one fourth 
of each tetrad. Since later stages show that the two chromatin masses in each spermatid of Fig. I I, $F$, represents two chromosomes, we see that the number of chromosomes has been reduced from the four in Fig. I $\mathrm{x}, A$, to two in Fig. $\mathbf{x}, F$. Manifestly the key to the explanation lies in the relations which exist between the four chromosomes of Fig. II, $A$, and the tetrads of Fig. I I, $B$. The two divisions consist merely in the distribution of the already separated parts of the tetrads; in the rearrangement of the four chromosomes into the two tetrads lies the possibility of the reduction which is carried out by the following divisions. The problem thus resolves itself into the question, What is the nature of each tetrad? Is it made up of a single chromosome, of two, of four, or have the constituent parts of the original four chromosomes become so completely rearranged and redistributed that their identity as such is completely lost?

Turning for a moment to the lower Crustacea, we find among the Copepods forms admirably suited for the

Reduction in

Crustacea.

careful following out of the changes taking place in the rearrangement of the chromosomes into the tetrads. To Rückert we owe the clearest account of the process as exhibited in the egg maturation of Cyclops. Here the normal number is $\mathbf{2 2}$, or perhaps $\mathbf{2 4}$, the minute size rendering counting difficult. In Fig. I $2, A$ to $F$, taken from Rückert, give the essential points of the formation of the tetrads and their following divisions, not all the chromosomes being represented. In Fig. 12, $A$, the chromatin filament has broken up into one half the usual number of segments (chromosomes), and each shows the precocious longitudinal splitting. These segments shorten up into the double rods of Fig. 12, $B$, which in Fig. I2, $C$, are being arranged in the developing spindle. A comparison of these three figures will show 


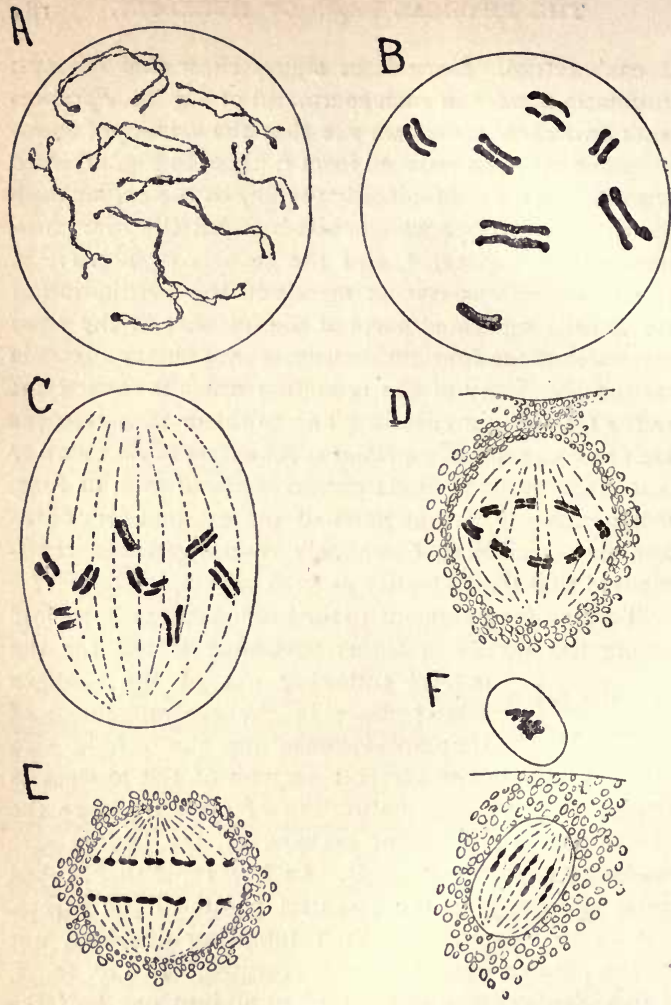

Fig. 12.-Maturation of the egg of Cyclops (the full number of chromosomes is not shown): A, germinal vesicle with the chromosomes already split longitudinally. B, the chromatin masses shortened, with indication of transverse division to form the tetrads. C, the young tetrads arranging themselves on the first polar-body spindle. $\mathrm{D}$, tetrads in first polar-body spindle. E, separation of the dyads in the same. $\mathrm{F}$, position of the dyads in second polar-body spindle: the first polar body is shown above the margin of the egg. (After Rückert.) 
clearly that each chromatin segment has divided both longitudinally and transversely, its parts shortening and arranging themselves in the tetrad formation of Fig. I2, $D$. The first division following separates the tetrad along the longitudinal plane of its former splitting (Fig. 1 2, E), and the second division along the transverse plane (Fig. I 2, $F$ ).

In Cyclops then the tetrads are formed by the chromatin thread of the resting nucleus breaking up into one half the usual number of segments, and each of these in turn dividing longitudinally and transversely. A tetrad here is made up of two chromosomes slightly united end to end and split longitudinally. Thus if abcdef $-\cdots n$ represent the unsegmented filament of the resting nucleus, $a-b-c-d-e-f$ would show its breaking up into the normal number of chromosomes which split lengthwise, forming $\frac{a}{a}, \frac{b}{b}, \frac{c}{c}, \frac{d}{d}, \frac{e}{e}, \frac{f}{f}$ in the equatorial plate. In the Cyclops nucleus of Fig. $A$ the filament has separated into the segments $a b-c d-e f \ldots n$, each of which has split longitudinally into $\frac{a b}{a b}, \frac{c d}{c d}, \frac{e f}{e f}$, etc., and its transverse division, subsequently becoming more apparent, gives to each tetrad the composition $\frac{a}{a}\left|\frac{b}{b}, \frac{c}{c}\right| \frac{d}{d}, \frac{e}{e} \mid \frac{f}{f}$, etc. By the first division, in the longitudinal plane, each daughter cell receives a half of each chromosome; in the second, however, in the vertical plane, this is not the case, as can be readily seen. This is clearly a qualitative division, and the daughter cells receive unlike chromosomes. This forms the "reducing division" in Weismann's sense, and as such is a most beautiful demonstration of his postulated reduction of the ancestral plasm.

In Ascaris, however, the evidence is just as clear 
that no reducing division in Weismann's sense takes place, though the actual number of the chromosomes is also reduced.

Boveri has shown for the egg and Brauer for the sperm that the tetrads arise by a double, longitudinal splitting of the chromatin filament which later breaks into two segments. Thus abcd would again represent the unsegmented filament, $a-b-c-d$ the individual chromosomes, and $\frac{a}{a}, \frac{b}{b}, \frac{c}{c}, \frac{d}{d}$ their splitting longitudinally in ordinary division. In the maturation of the egg and in spermatogenesis, however, the thread segments into $a b$, $c d$, and splits twice longitudinally into $\frac{a b}{a b}\left|\frac{a b}{a b}, \frac{c d}{c d}\right| \frac{c d}{c d}$, the two tetrads of $B$ in Fig. $\mathbf{I}$. The reduction of chromatin here is only a reduction in mass and not a qualitative one, in Weismann's sense, as in the Crustacea and insects. In Ascaris the actual reduction in number of chromosomes takes place in the nucleus previous to the maturation divisions of the ovocyte and spermatocyte respectively. In Cyclops the formation of the tetrads is merely a pseudo-reduction, the actual reduction taking place in the second division which gives rise to the mature egg on the one hand, or to the spermatids, which develop into the spermatozoa, on the other.

One fundamental fact is clear in these divergent accounts. The number of the chromosomes is reduced in both sorts of the germinal cells as a preliminary to their union. Whether there is likewise a qualitative distribution of the chromatin elements remains for future investigation to decide.

From the facts of ordinary cell division we have seen the probability of the hypothesis that the chromatin of the nucleus is to be regarded as the bearer of hereditary qualities in the cell. The phenomena of fertilization 
greatly increase this probability. The offspring resembles both of its parents, and the paternal tendencies can be conveyed in the minute sperma-

The chromatin as the bearer of hereditary influences. tozoan head alone, which is constituted almost entirely of chromatin. The scrupulous exactitude with which, in both germ cells, the chromosomes are reduced to one half the normal number preparatory to the union of the pronuclei in fertilization, and the distribution of the paternal and maternal chromatin Indirect evidence. equally to the resulting cells of cleavage, lend added weight to the theory. It remained for the genius of Boveri by a brilliant experiment to raise this hypothesis to the plane of almost absolute certainty. The crucial test of the theory would be to remove the nucleus from one cell Direct experimental evidence. and to substitute it in the place of the nucleus of another. If the nucleus and cytoplasm thus brought into union are so constituted that they can exist together, then one of three things will happen. Either the qualities of the cell from which the nucleus was taken will develop, or those of the cytoplasm, or those formed by the union of both nucleus and cytoplasm.

In this first case nuclear control will be demonstrated; in the second, cytoplasmic; and in the third, an interaction of both nucleus and cytoplasm will determine the activities of the cell.

Such an experiment was first tried by Rauber in endeavouring to remove the nucleus of the fertilized frog's egg, and to substitute for it the nucleus from a toad's egg in the same stage of development. If the nucleus contains the hereditary influences, then a toad must develop from the union of frog's cytoplasm and toad nucleus. The profound disturbances set up in the 
operation, however, effectively precluded any success, and the eggs did not develop.

Boveri selected for his experiments the eggs of two different species of sea urchins, Echinus microtuberculatus and Spharechinus granularis, both found in abundance at Naples. He found that, if the minute eggs of either of these were shaken vigorously in a test tube, in a small amount of sea-water, for a few minutes, they would break up into variously sized fragments, some of which contained nuclei while others did not. These fragments could be fertilized, and development would proceed regularly, the dwarf larvæ resulting resembling in all particulars the normal larvæ, save for a small percentage of deformation caused by the shaking. This development took place in the non-nucleate fragments as well as in those which contained nuclei, the spermatozoa penetrating into both with equal readiness. The larval forms of the two genera Echinus and Shpharechinus are so sharply defined that they can be recognised at the end of the second or third day's development with unfailing accuracy. Fig. $\mathrm{r}_{3}, C$ and $D$, illustrate in front and side view a normal larva of Spharechinus, Fig. r3, $A$ and $B$, the same of Echinus. The general contour and shape of the larva, and more especially the widely differing calcareous skeletons of the two forms, render their ready distinction a very easy matter, and a closer analysis will reveal a large number of minor points of difference.

After determining these facts, Boveri's next step was to cross-fertilize the eggs of Spharechinus with sperm from Echinus. In a small percentage of cases this succeeded, and the resulting larvæ were uniformly of a type as shown in Fig. $14, A$ and $B$, in front and side view-a form which stands midway between the normal larvæ of the parents, and combines the character- 

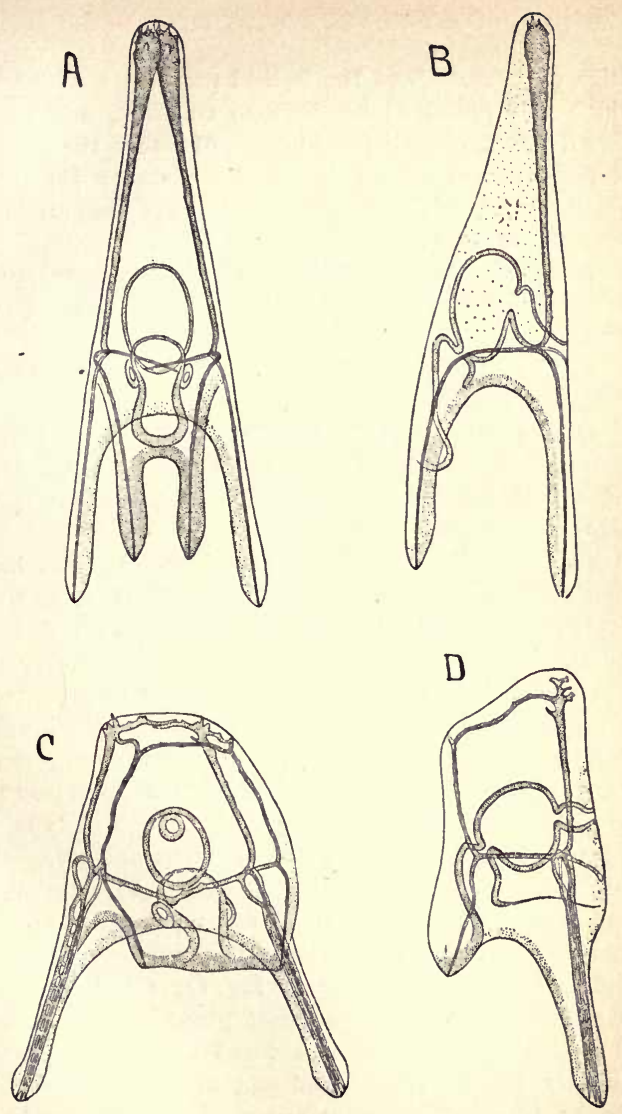

FIG. 13.-A, normal larva of Echinus microtuberculatus; front view. B, the same ; side view. C, Normal larva of Spharechinus granularis; front view. D, the same; side view. (After Boveri.) 
istics of both. Thus the hybrid presents a new type, which was found to be likewise constant, and in no case did it approach the likeness of either the Echinus or Spharechinus type, so as to be mistaken for them. Thus were established four preliminary essentials to the experiment, viz. :

I. The constancy of the normal Echinus larval type.

2. The constancy of the normal Spharechinus larval type.

3. The constancy of the new hybrid type between Echinus $\delta$ and Spharechinus $\$$.

4. The possibility of securing non-nucleated fragments of Spharechinus eggs by shaking, which were capable of fertilization, and from which dwarf larvæ might be reared.

The crucial point in the experiment, as may have been already anticipated, was to cross-fertilize non-nucleated fragments of Spharechinus eggs with Echinus sperm. The type of larva resulting would decide the point in question. Here we may have a nucleus from one species introduced into the non-nucleated cytoplasm of another species by a perfectly normal process -i. e., by the penetration of the spermatozoan into the egg. If the resulting larva be of the hybrid type, as shown in Fig. 14, $A$ and $B$, then nucleus and cytoplasm both unite in determining the hereditary characteristics; if the pure Spharechinus type of Fig. I3, $C$ and $D$, results, then the cytoplasm alone bears these influences; while, finally, if the type be that of Fig. 13, $A$ and $B$, to the spermatozoan nucleus alone must be ascribed the hereditary qualities. The larvæ secured by Boveri were of the pure Echinus or paternal type, as is well shown in Fig. ${ }_{1}, C$ and $D$. A comparison of these figures with Fig. $\mathrm{x}_{3}, A$ and $B$, show unmistakably that this is the case. No trace of the Spharechinus, or maternal, char- 

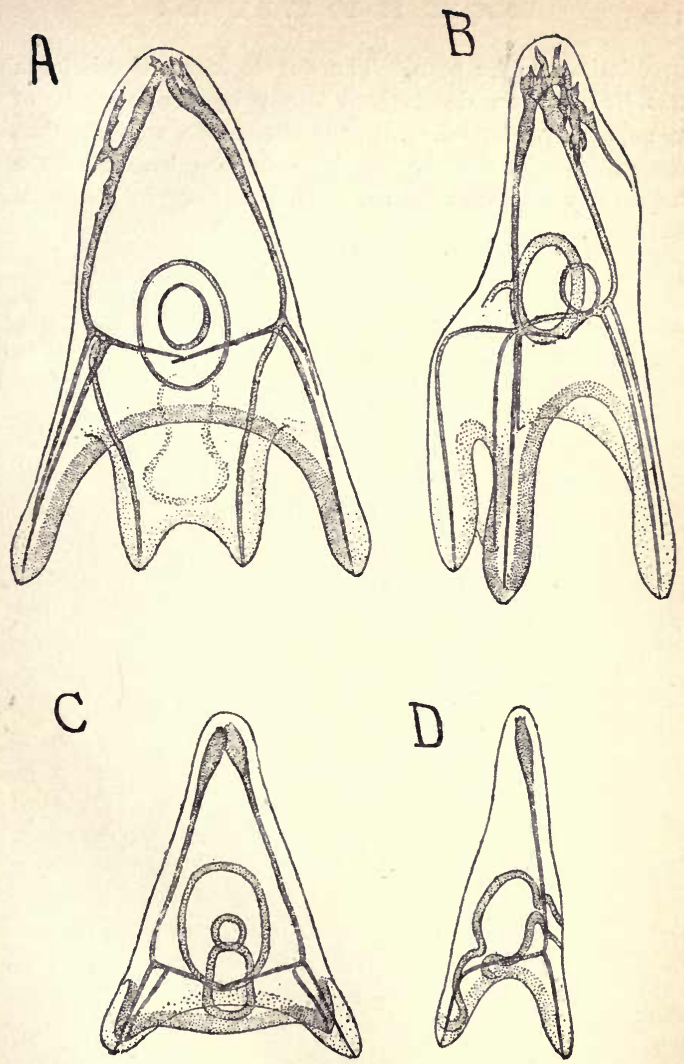

FIs. I4.-A, hybrid larva of Spharechinus $\&$, and Echinus 8 : front view. $B$, the same; oblique, side view. $C$, dwarf hybrid larva of Spharechinus of (non-nucleated egg fragment), and Echinus s, of pure Echinus type. D, the same larva in side view. (After Boveri.) 
acteristics can be seen. The development of this larva has hence been determined solely by the nucleus of the spermatozoan-i. e., by the chromatin, which is thus experimentally demonstrated to be the bearer of the hereditary qualities in the cell, the material basis of heredity. 
VII.

THE DISTRIBUTION OF. SPECIES.

IN the present paper I shall consider certain facts of animal distribution as related to the origin of species. There are many difficulties in Illustrations not bringing the facts of geographical distri-
arguments. bution down to the needs of concrete illustration. And in this connection it is especially important to distinguish single illustrations from arguments. Isolated cases of geographical variations in species, for example, would not have great value as arguments for the development theory were the cases really isolated. The force lies in this fact, that these cases are typical; that what may be said of one is true of a thousand. In like manner the full force of the laws of homology and heredity can only be felt when their effect is cumulative, as in the mind of the anatomist who has followed each organ through its protean disguises in a wide range of forms. Again, the force of the argument drawn from embryology does not come from a knowledge of the changes in a single egg. All these studies need the second premise, obtained by years of comparison in different fields of investigation, that no case is isolated. Without this premise, the argument would be incomplete. The few cases of development or change which can be brought to popular notice are simply illustrations and not proofs. 
As Professor Bergen has well said, "It is important that we should understand that none of the kinds of Cumulative evidence. evidence in favour of evolution loses so much by being represented only by scattered instances as the argument from distribution." And, conversely, no argument is more conclusive when all the known facts are brought into consideration together. The universal fact of the mutability of species can be really understood or appreciated only by him who has seen with his own eyes the changes in multitudes of species. To the ordinary observer the species seem constant, just as the face of a cliff seems constant. To the student of Nature, mutability is everywhere. Just as the wind and rain and frost quietly but surely change the face of a cliff, so do other forces of Nature as quietly but as surely change the face of a species.

It was this phase of the subject, the relation of species to geography, which first attracted the attention both of Darwin and Wallace. Both these observers noticed that island life is neither strictly like nor unlike the life of the nearest land, and that the degree of difference differs with the degree of isolation. Both were led from this fact to the theory of derivation, and to lay the greatest stress on the progressive modification resulting from the struggle for existence.

In the voyage of the Beagle Darwin was brought in contact with the singular fauna of the Galapagos The fauna of the Galapagos. Islands, that cluster of volcanic rocks which lies in the open sea about six hundred miles west of the coasts of Ecuador and Peru. The sea birds of these islands are essentially the same as those of the coast of Peru. So with most of the fishes. We can see how this might well be, for both sea birds and fishes can readily pass from the 
one region to the other. But the land birds, as well as the reptiles, insects, and plants, are mostly peculiar to the islands. The same species are found nowhere else. But other species very much like them in all respects are found, and these all live along the coast of Peru. In the Galapagos Islands, according to Darwin's notes, "there are twenty-six land birds; of these, twenty-one, or perhaps twenty-three, are ranked as distinct species, and would commonly be assumed to have been here created; yet the close affinity of most of these birds to American species is manifest in every character, in their habits, gestures, and tones of voice. So it is with the other animals and with a large proportion of the plants. ... The naturalist, looking at the inhabitants of these volcanic islands in the Pacific, feels that he is standing on American land."

This question naturally arises: If these species have been created as we find them on the Galapagos, why is it that they should all be very similar in type to other animals, living under wholly different conditions, but on a coast not far away? And, again, why are the animals and plants of another cluster of volcanic islandsthe Cape Verde Islands-similarly related to those of the neighbouring coast of Africa, and wholly unlike those of the Galapagos? If the animals were created to match their conditions of life, then those of the Galapagos should be like those of Cape Verde, the two archipelagoes being extremely alike in soil, climate, and physical surroundings. If the species on the islands are products of separate acts of creation, what is there in the nearness of the coasts of Africa or Peru to influence the act of creation so as to cause the island species to be, as it were, echoes of those on shore?

If, on the other hand, we should adopt the obvious suggestion that both these clusters of islands have been 
colonized by immigrants from the mainland, the fact of uniformity of type is accounted for, but what of the difference of species? If the change of conditions from continent to island cause such great and permanent changes as to form new species from the old, why may not like changes take place on the mainlands as well as on the islands? And if possible on the mainland of South America, what evidence have we that species are permanent anywhere? May they not be constantly changing? May not what we now consider as distinct species be only the present phase in the changing history of the series of forms which constitute the species?

The studies of these and many similar facts can lead but to one conclusion:

These volcanic islands rose from the sea destitute of land life. They were settled by the waifs of wind and Island life. of storm, birds and insects blown from the shore by trade winds, lizards carried on drift logs and floating vegetation. Of these waifs few came perhaps in any one year, and few perhaps of those who came made the islands their home; yet, as the centuries passed on, suitable inhabitants were found. That this is not fancy we know, for we have the knowledge of many ways in which animals are carried from their natural homes. One example of this may be seen by those who have approached our eastern shores by sea in the face of a storm. Hosts of land birds-sparrows, warblers, chickadees, and even woodpeckers-are carried out by the wind, a few falling exhausted on the decks of ships, a few others falling on off-shore islands, like the Bermudas, the remainder drowned in the sea.

Of the immigrants to the Galapagos the majority doubtless die and leave no sign. A few will remain, multiply, and take possession, and their descendants are 
thus native to the islands. But, isolated from the great mass of their species and bred under new surroundings, these island birds come to differ from Effects of migratheir parents, and still more from the tion on species. great mass of the land species of which their ancestors were members. Separated from these, their individuality would manifest itself. They would assume with new environment new friends, new foes, new conditions. They would develop qualities peculiar to themselves-qualities intensified by isolation. "Migration," says Dr. Coues, "holds species true; localization lets them slip." This would be more exactly the truth should we say that localization holds peculiarities true; migration lets them slip. Local peculiarities disappear with wide association, and are intensified when individuals of similar peculiarities are kept together. Should later migrations of the original land species come to the islands, the individuals surviving would in time form new species, or, more likely, mixing with the mass of those already arrived, their special characters would be lost in those of the majority.

The Galapagos, first studied by Darwin, serve to us only as an illustration. The same problems come up Effects of isolation. in one guise or another in all questions of geographical distribution, whether of continent or island. The relation of the fauna of one region to that of another depends on the ease with which barriers may be crossed. Distinctness is in direct proportion to isolation. What is true in this regard of the fauna of any region as a whole is likewise true of any of its individual species. The degree of resemblance among individuals is in direct proportion to the freedom of their movements, and variations within what we call specific limits is again proportionate to the barriers which prevent equal and perfect diffusion. 
The various divisions or realms into which the surface of the earth may be divided on the basis of the differences in animal life, each has its Barriers to diffusion. boundary in the obstacles offered to the spread of the average animal. Each species broadens its range as far as it can. It struggles, knowingly or not, to overcome the barriers of ocean or river, of mountain or plain, of woodland or desert, of moisture or drought, of cold or heat, of lack of food or abundance of enemies-whatever these barriers may be. Were it not for these barriers, every species would become what only man now is, practically cosmopolitan. Man is pre-eminently the barrier-crossing animal. The degree of hindrance offered by any barrier to the extension of species is only relative. That which constitutes an impassable barrier to some groups is a high road to others. The river which opposes the passage of the monkey or the cat would be the king's highway to the frog or the turtle. The waterfall which checks the ascent of the fish is the chosen home of the ouzel.

In spite of the great variety among the barriers existing on the earth, we may divide the globe roughly into five realms or areas of distribution, having their boundaries in the sea or in differences of climate. One or two of these realms are sharply defined; the others are surrounded by a broad fringe of debatable ground, which forms a region of transition to some other zone.

The largest of these realms is the holarctic realm, which comprises nearly all of Asia, Europe, and North Holarctic realm. America, the arctic and north temperate zones. The north temperate zone has practically a continuous climate, the chief variations being in elevation and rainfall. The close union of Alaska to Siberia forms an almost unbroken land area from the eastern coast of America around to western 
Europe. To the south the species increase in number and variety; the arctic regions are remarkable for what they lack, yet the general character of the life is almost unbroken over this vast district. Alfred Russell Wallace refers to this unity of northern life in these words :

"When an Englishman travels by the nearest sea route from Great Britain to northern Japan, he passes by countries very unlike his own both in aspect and in natural productions. The sunny isles of the Mediterranean, the sands and date palms of Egypt, the arid rocks of Aden, the cocoa groves of Ceylon, the tigerhaunted jungles of Malacca and Singapore, the fertile plains and volcanic peaks of Luzon, the forest-clad mountains of Formosa, the bare hills of China pass successively in review, until after a circuitous journey of thirteen thousand miles he finds himself at Hakodate, in Japan. He is now separated from his starting point by an almost endless succession of plains and mountains, arid deserts or icy plateaus; yet, when he visits the interior of the country, he sees so many familiar natural objects that he can hardly help fancying he is close to his home.' He finds the woods and fields tenanted by tits, hedge sparrows, wrens, wagtails, larks, redbreasts, thrushes, buntings, and house sparrows, some absolutely identical with our own feathered friends, others so closely resembling them that it requires a practised ornithologist to tell the difference. . . . There are also, of course, many birds and insects which are quite new and peculiar, but these are by no means so numerous or conspicuous as to remove the general impression of a wonderful resemblance between the productions of such remote islands as Britain and Yesso." (Island Life.)

A journey to the southward from Britain or Japan or Illinois, or any point within the holarctic realm, would show the successive changes in the character of 
life, though gradual, to be more rapid. The barrier of frost which keeps the fauna of the tropics from encroaching on the northern regions once crossed, we come to the multitude of animals whose life depends on sunshine, the characteristic forms of the neotropical realm.

The neotropical realm includes South America, the West Indies, and the hot coast lands of Mexico and Neotropical realm. Central America. To the northward this realm overlaps the holarctic in the transition regions of Sonora, Arizona, Texas, and Florida; but to the southward the barrier of the broad ocean keeps it practically distinct from all others. The richness of this fauna in forms and species makes the great forests of the Amazon the dream of the naturalist. Joaquin Miller gives a vivid picture of the life of tropical America :

" Birds hung and swung, green-robed and red, Or drooped in curved lines dreamily, Rainbows reversed from tree to tree;

Or sang, low hanging overhead, Sang soft as if they sang and slept, Sang low like some far waterfall, And took no note of us at all."

Corresponding to the neotropical realm in position, but with a less rich and varied fauna, is the Ethiopian Ethiopian realm.
of Africa, merging gradually on the north into the holarctic realm, through the transition regions of Barbary, Italy, and Spain. In monkeys, herbivorous animals, and reptiles, this region is wonderfully rich. In variety of birds and fishes the neotropical region far surpasses it.

The Indian realm comprises southern Asia and the neighbouring islands. Its rich fauna has much in com- 
mon with that of Africa, and it is, moreover, surrounded by transition districts which lead on the north to the Indian realm. holarctic and on the west to the Ethiopian. On the east the Indian realm is lost in the islands of Polynesia, which represents each one its own degree of transition and isolation.

The Australian realm of Australia and its islands is more isolated than any of the others. It shows a sinAustralian gular development of low or primitive realm.

types of vertebrate life, as though in the progress of evolution this continent had been left a whole geological age behind the others. It is certain that, could the closely competing fauna of the holarctic or Indian realms have been able to invade Australia, the dominant mammals and birds of that region would not have been marsupials and parrots. Unspecialized types abound only where barriers have prevented competition. The larger the land area the greater the competition and the more specialized its characteristic forms. As part of this specialization is in the direction of hardiness, the species of the large experience are the more persistent and less easy of extermination. The rapid multiplication which certain holarctic animals and plants have shown when transported to the Australian realm, demonstrates what might have taken place if impassable barriers had not previously shut them out.

Each of these great realms may be indefinitely subdivided into provinces and sections, for there is no end to the possibility of analysis. No township or school district has exactly the same animals or plants as any other; and, finally, in ultimate analysis, no two animals or plants are alike. Modification comes with the growth of each new individual, and steadily increases with the individual's separation in time or space from the parent stock. Moreover, we observe apparent anomalies of 
distribution in every realm; here appears an animal, there a plant, which seems to have a character or place which it ought not to hold. To the result of unexpected Anomalies in distribution. or chance crossing of barriers these apparent anomalies in geographical distribution are due. Anomalies in distribution, like anomalies in evolution, would cease to be such if we knew all the facts and circumstances of their previous history. The present range of the tapir in farther India and in the northern part of South America, two widely separated regions, is at first sight an anomaly of distribution. This anomaly disappears when we know that formerly the tapir ranged over the holarctic realm, and became gradually extinct with the changing climate. The bones of a tapir, much like one of the South American species, are found in recent clays in Indiana (Ellettsville, Monroe County), and similar remains exist in France, in China, and in Burmah. The isolated, unexterminated colonies are now left at the extreme of the animal's former range, and these colonies at present constitute what we call distinct species.

The more extended are our studies the fewer are the anomalies which arrest our attention, and the fewer are the distinctive or characteristic forms. Adaptation of animals to environment.

There is little foundation for the current belief that each species of animal has originated in the area it now occupies, for in many cases our knowledge of palæontology shows the reverse of this to be true. Even more incorrect is the belief that each species occupies the district or the surroundings best fitted for its habitation. This is manifest in the fact of the extraordinary fertility and persistence shown by many kinds of animals and plants in taking possession of new lands, which have become, through the voluntary or involuntary interference of 
man, open to their invasion. Facts of this sort are the "enormous increase of rabbits and pigs in Australia and New Zealand, of horses and cattle in South America, and of the sparrow in North America, though in none of these cases are the animals natives of the countries in which they thrive so well." (Wallace.) The persistent spreading of European weeds to the exclusion of our native plants is a fact too well known to every farmer in America. The constant movement westward of the whiteweed and the Canada thistle marks the steady deterioration of our grass fields. Especially

Invasion of the

Australian realm. noteworthy has been this change in Australia and New Zealand. In New Zealand the weeds of Europe, toughened by centuries of struggle, have won an easy victory over the native plants. Edward Wakefield, in his history of New Zealand, says that "many animals and birds acquire peculiarities in the new country which would indeed astonish those accustomed to them in the old. They usually run to a much larger size and breed oftener. They also take to strange kinds of food. Birds deemed granivorous at home become insectivorous here, and vice versa. Some learn the habits of the native species. Skylarks imitate the native wagtail, and may often be seen perching on fences and telegraph wires. They sing in the nighttime, too, a thing unheard of in the old country, and doubtless acquired from the nocturnal habits of the New Zealand birds."

The European house fly in New Zealand has completely extirpated the large bluebottle fly, which was formerly a source of great annoyance to the settlers. An account is given of a farmer who filled a bottle with house flies and carried them eighty miles into the country, liberating them, one by one, in the vicinity of his sheepfolds, in order to let them take the place of the. 
native flies. It is said that red clover would not grow in New Zealand until bumblebees were introduced to fertilize its flowers. Wakefield estimates that the introduction of these large wild bees has been worth five million dollars to the farmers in New Zealand.

Dr. Edward L. Youmans quotes from Dr. Hooker the statement that, in New Zealand, "the cow grass has taken possession of the roadsides; dock and water cress choke the rivers; the sow thistle is spread all over the country, growing luxuriantly up to six thousand feet; white clover in the mountain districts displaces the native grasses." The native (Maori) saying is, "As the white man's rat has driven away the native rat, as the European fly drives away our own, and the clover kills our fern, so will the Maoris disappear before the white man himself."

Prof. Sidney Dickinson gives the following valuable notes on the rabbit and other plagues of Australia :

"The average annual cost to Australasia of the rabbit plague is $£ 700,000$, or nearly $\$ 3,500,000$.

"The work which these enormous figures represent has a marked effect in reducing the number of rabbits in the better districts, although there is little reason to suppose that their extermination will ever be more than partial. Most of the larger runs show very few at present, and rabbit-proof fencing, which has been set around thousands of square miles, has done much to check further inroads. Until this invention began to be utilized it was not uncommon to find as many as a hundred rabbiters employed on a single property, whose working average was from three hundred to four hundred rabbits per day. As they received five shillings a hundred from the station owner, and were also able to sell the skins at eight shillings a hundred, their profession was most lucrative. Seventy-five dollars a week was not an uncommon wage, and many an unfortunate squatter 
looked with envy upon his rabbiters, who were heaping up modest fortunes, while he himself was slowly being eaten out of house and home.

"The professional rabbiter is not an agreeable companion. He is covered with the fluffy fur of his quarry until he bears much of the appearance of a mouldy cheese; his clothing is streaked with blood and dirt, and from his hair and beard, and, in fact, from his entire person, exhales a strong leporine odor. Not until he attains this consummation can he hope for the highest success in his profession, for the game on which he wars is gifted with keen sensibilities, and will avoid the trap or the fatal phosphorized grain that has been placed in its way by hands ordinarily clean.

"The fecundity of the rabbit is amazing, and his invasion of remote districts swift and mysterious. Careful estimates show that, under favourable conditions, a pair of Australian rabbits will produce six litters a year, averaging five individuals each. As the offspring themselves begin breeding at the age of six months, it is shown that, at this rate, the original pair might be responsible in five years for a progeny of over twenty millions. That the original score that were brought to the country have propagated after some such ratio, no one can doubt who has seen the enormous hordes that now devastate the land in certain districts. In all but the remoter sections, however, the rabbits are now fairly under control; one rabbiter with a pack of dogs supervises stations where one hundred were employed ten years ago, and with ordinary vigilance the squatters have little to fear. Millions of the animals have been killed by fencing in the water holes and dams during a dry season, whereby they died of thirst, and lay in enormous piles against the obstructions they had frantically and vainly striven to climb, and poisoned 
grain and fruit have killed myriads more. A fortune of $£^{25}, 000$ offered by the New South Wales Government still awaits the man who can invent some means of general destruction, and the knowledge of this fact has brought to the notice of the various colonial governments some very original devices.

"Another great pest to the squatters is developing in the foxes, two of which were imported from Cumberland some years ago by a wealthy station owner, who thought that they might breed, and give himself and friends an occasional day with the hounds. His modest desires were soon met in the development of a race of foxes far surpassing the English variety in strength and aggressiveness, which not only devour many sheep, but out of pure depravity worry and kill ten times as many as they can eat. When to these plagues is added the ruin of thousands of acres from the spread of the thistle, which a canny Scot brought from the Highlands to keep alive in his breast the memories of Wallace and Bruce; the well-nigh resistless inroads of furze; and, in New Zealand, the blocking up of rivers by the English watercress, which in its new home grows a dozen feet in length, and has to be dredged out to keep navigation open, it may be understood that colonials look with jaundiced eye upon suggestions of any further interference with Australian nature.

"Not to be outdone by foreign importations, the country itself has shown in the humble locust a nuisance quite as potent as rabbit, fox, or thistle. This bane of all men who pasture sheep on grass has not been much in evidence until within the last few years, when the great destruction of indigenous birds by the gun and by poisoned grain strewn for rabbits has facilitated its increase. The devastation caused by these insects last year was enormous, and befell a district a thousand 
miles long and two hundred wide. For days they passed in clouds that darkened the earth with the gloomy hue of an eclipse, while the ground was covered with crawling millions, devouring every green thing, and giving to the country the appearance of being carpeted with scales. It has been discovered, however, that before they attain their winged state they can easily be destroyed, and energetic measures will be taken against them throughout all the inhabited districts of Australia whenever they make another appearance." (Station Life in Australia, Scribner's Magazine, February, 1892, pp. 136-154.)

I was lately called to examine a specially interesting problem in geographical distribution, that of the dispersion of fishes in the Yellowstone Park. Trout in Yellow- This region is a high volcanic plateau, stone Park.

formed by the filling of a mountain basin with a vast deposit of lava. The streams of the park are for the most part among the coldest and clearest of the Rocky Mountains, and apparently in every way suitable for the growth of trout. All the hot springs of the great geyser basin are not sufficient to warm the waters of the Firehole River. Yet, with the exception of the Yellowstone itself, all these streams are destitute of fish life. A reason for this is apparent in the fact that the plateau is fringed with cataracts which no fish can ascend. Each stream has a cañon and waterfall near the point where it exchanges the hard bed of lava for the rock below. So the best of trout streams, for an area of fifteen hundred square miles, are left without trout, because their natural inhabitants can not get to them.*

* Since this was written, the principal waters of this region have been stocked with trout of different species, and these have multiplied with great rapidity. There is now an abundance of trout in the Firehole, Gibbon, Gardiner, and Lewis Rivers, as well as in Shoshone Lake. 
On the theory that each species occupies those places best suited to its life, this fact would represent a great oversight on the part of Mother Nature. But with this is the curious fact that the Yellowstone itself, both above and below its falls, is well stocked with trout and with no other fish. This is an anomaly of distribution, but this anomaly disappears when we examine the continental divide at the head of the Yellowstone. At Two-ocean Pass. one point, as Dr. Barton W. Evermann, Dr. Oliver P. Jenkins, and others have shown, the Two-ocean Pass, only about an eighth of a mile of wet meadow and marsh, separates the drainage of the Yellowstone from that of the Columbia. From the Columbia the Yellowstone has therefore received its trout. No doubt every anomaly of distribution would become perfectly simple could we only know all the facts concerned in the case.

Laws of distribu-

The laws of geographical distribution of animals. tion of animals reduce themselves to these very simple propositions:

Every species of animal may be found in any part of the earth, unless:

I. It has been unable to reach that region, through barriers of some sort, or,

2. Having reached it, it is unable to maintain itself, in competition with other forms, or on account of the conditions of environment, or else,

3. Having maintained itself, it has become so altered through natural selection as to become a species distinct from its ancestors.

The primary barriers to distribution are the heights of the land and the depths of the sea-physical obstacles not to be crossed. Next in importance is the barrier of climate. With some forms of life this is absolute, for the palm and the banana are the index of the torrid zone as 
the dwarf birch and reindeer moss are the index of the frigid. "Plants," says Dr. Gray, " are the thermometers of the ages by which climatic extremes and climates in general are best measured." In many groups anatomBarriers of land, sea, and climate.

ical characters are not more profound or of longer standing than are the adaptations to heat and cold. Heat-loving animals are far more numerous in species than animals of cold climates, though the latter often make up by greater abundance of individuals. Barriers less important than those of climate arise from external surroundings-from absence of means of defence, from character of food, of air, of water, and the presence of various enemies. These conditions vary in their importance with each group of animals, yet apparently the least of them may be able to limit the range of species. To limit the range is the first step toward extinction, for to cease to advance is to retreat. Adverse conditions may invade even the heart of its distribution, causing reduction of numbers, which, if long continued, must mean rarity and final extermination. Extinction comes to those species we call rare, and its advent must be unnoticed. Circumstances become unfavourable to the growth or reproduction of some animal. Its numbers are reduced-it is rare-it is gone.

The air in Indiana and Kentucky but a few years since was dark with the hordes of passenger pigeons at the time of their fall migrations. The advance of a tree-destroying, pigeon-shooting civilization has gone steadily on, and now the bird which once filled our western forests is in the same region an ornithological curiosity.

A very slight change in the environment of any species may be a matter of the greatest moment as regards its increase or permanence. The dependence of the clover on the number of cats in a certain neighbourhood is an 
illustration given us by Mr. Darwin. The clover depends on the bumble-bee for the fertilization of its pods. The Interdependence nests of the bumblebee are destroyed by of species.

the field mouse, which is thus an enemy of the clover. The balance is restored by the work of the cat, who captures the mouse and prevents its ravages on the nests of the bee. The old nursery jingle of "the cow that tossed the dog that worried the cat that killed the rat" is repeated throughout $\mathrm{Na}$ ture. With any change in any of the elements in this series the whole equilibrium of Nature is interrupted. For this equilibrium is apparent only-a sort of armed neutrality, an established order of things which the superficial observer mistakes for real peace and permanence.

In some groups we find evidence of a progressive adaptation of individuals to circumstances-for example, The arctic birch. to climate, ending in the formation of new species to accord with changed conditions of temperature. We may illustrate this by means of the arctic birches. In Norway, as in most northern regions with a moist climate, there are large forests of birches. In the valleys, where the summers are warm and reasonably long, the birches of different species grow to be considerable trees. Farther to the north, or higher up the mountains, the summer is too short for the growth of birch trees and their place is taken by birches which never pass beyond the size of small bushes. Still higher up there are birches even where snow falls every month of the year, and the distant sun gives only a glimpse of summer in July. Competition with other plants is, of course, not severe in such regions, but the birches must struggle against the weather. They can live and multiply if only they can adjust themselves to the conditions of life. They must 
keep down their size, they must carry as little foliage as possible, and their stems must be tough enough to resist snow and hardy enough to withstand almost perpetual frost. Their year's growth must be finished in a very short time, and leaves, flowers, and seeds must follow in the most rapid succession. In short, there is room for birch trees here, if only the trees can be reduced to their lowest terms. And so birch trees have crept up the mountain sides even to the very edges of the perpetual snow. But such trees! All trees requiring sunshine, or long time for their summer's growth, are rigidly kept away by "natural selection."

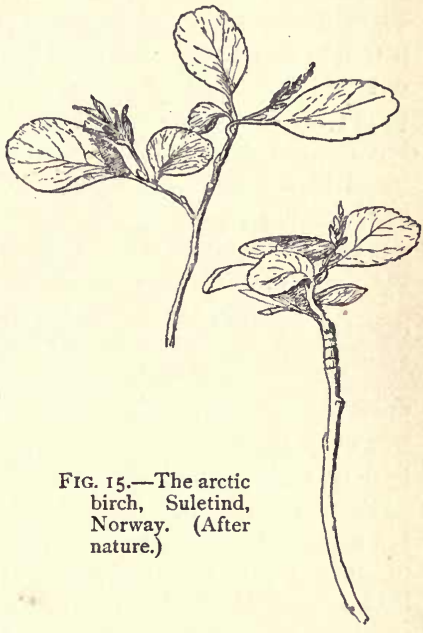

The cold climate dwarfs the individual, and the hard conditions exclude every individual not dwarfed. I have before me three birch trees from a Norwegian mountain called the "Suletind"- -the little trees known to the Norwegian peasants as "Hundsöire, or " dogs'-ears." The trunk of each tree is barely an inch in height. There are no branches and but three leaves. Half inclosed by the uppermost leaf is the single little catkin of flowers. Leaves in June, blossoms in July, fruit in August, and then the little tree is ready for its nine 
months' sleep. These little trees are the Lapps of forest vegetation.

All natural history is full of similar cases of modifications. Everywhere there is the most perfect adaptation of life to its conditions. But this adaptation must come about through the survival of those organisms fittest to live under the conditions, while the unfit die out and leave no progeny. But fitness is a relative term; for in many cases, as with the Norwegian dwarf birches, the deformed or stunted may be the only ones fitted to survive. An advantage ever so slight must in the long run conquer.

The arctic birches serve as one illustration only of the spread and change of organisms in the face of barCrossing the barriers. riers apparently insurmountable. I can not enter into details as to the many ways in which individuals manage to cross the barriers which usually limit the species. These ways are as varied as the creatures themselves, and infinitely more varied than the barriers. By the longcontinued process of adjustment to circumstances, with the incessant destruction of the unadapted, the various organisms have become so well fitted to their surroundings as to give rise to the popular impression that each species now inhabits that part of the world best fitted for its occupation. Yet the very reverse of this must be true, for in the growth of any species it is these features of adaptation which are the last to appear. If the history of the individual is an epitome of the history of the group to which the individual belongs, then adaptive characters appearing late in the growth of the individual must have appeared late in the history of the group. They are the last changes made in the organism-mere after-thoughts in the work of creation. 
For example, the long pectoral fins of the flying fish enable it to make long leaps through the air, after the The flying fish. manner of the grasshopper. Yet we can not say that the flying fish was meant to be the bird among fishes, for its nearest relatives are without wings, and the wing development is one of the latest acquisitions of the individual. Its flight is simply an exaggeration of the leaping or skimming which related forms with shorter fins accomplish. The growth of the fins goes on with the increase of this power, and greater power comes with the growth of the fins. Morphologically, a flying fish is even less like a bird than the humbler fishes from which it is descended.

No phase in the history of systematic science is more instructive than the varying attitudes of the naturalist toward those local modifications of species called subspecies or geographical variations.

It was early noticed that, while individuals of any one species in any limited region are substantially alike, Subspecies or geographical variations. this apparent identity disappears with the examination of wider extent of territory. These differences were often too small to justify the formation or recognition of a new species, but too evident to be wholly neglected. Such subordinate species were termed by Linnæus varieties, and their geographical basis was of ten recognised. Thus under Homo sapiens, or aboriginal man, Linnæus recognised four varieties-americanus, europous, asiaticus, and afer, besides the half-mythical monstrosus, based on traveller's tales of Patagonians, Hottentots, and dwarfs. As with the varieties of man, so with those of other animals and plants. The individuals of England were not quite those of the same species in Italy, and those in more distant lands showed still greater peculiarities. 
Sometimes these qualities could be exactly measured, in which case a new species was described. SomeDoubtful species. times they proved elusive, and the supposed new species were added to the great dust heap of synonymy. The work of the systematic zoologists of the last generation was chiefly in museum cataloguing and labelling. To them these half-tangible varieties were the object of special opprobrium. On the museum shelves they were simply a nuisance, obscuring the characters of the real species and throwing closet-formed ideas of Nature into utter confusion. Professor Cope tells us how variant shells have been crushed under the heel of the indignant conchologist because they would go neither into species "A " nor species “ B." Specimens were often preserved from "typical localities," so that no confusion might be introduced among the cherished specific characters. That Nature went on producing these varying and intermediate forms was no concern of the zoologist. That such forms were any part of Nature's real plan apparently never occurred to the followers of Linnæus.

Says the botanist De Candolle: "They are mistaken who suppose that the greater part of our species are clearly limited, and that the doubtful species are in a feeble minority. This seemed to be true as long as a genus was imperfectly known, and its species were founded on a few specimens-that is to say, were provisional only; just as we come to know them better, intermediate forms flow in, and doubts as to the limits of the species become more numerous."

The ease with which slight variations have deceived and confused naturalists has been one of the most discouraging features in the history of science. Such variations have formed the basis of thousands of useless and distracting names. 
When Darwin was at work upon his monograph of the barnacles (Cirripedia), he wrote to a friend: "Sys-

Darwin's experience. tematic work would be easy were it not for this confounded variation, which, however, is pleasant to me as a specialist, though odious as a systematist. . . . How painfully true is your remark that no one has hardly a right to examine the question of species who has not minutely described many !... Certainly I have felt it humiliating, discussing and doubting and examining, over and over again, when in my mind the only doubt has been whether the form varied from to-day or yesterday. . . . After describing a set of forms as distinct species, tearing up my manuscripts and making them one species, tearing that up and making them separate, and then making them one again (which has happened to me), I have gnashed my teeth, cursed species, and asked what sin I had committed to be so treated."

An epoch in systematic zoology began with the study of the collections made by the United States Pacific The Ralway survey some forty years ago. way surveys. Then for the first time was opened to naturalists the details of the fauna of a vast district under the same parallels of latitude, but showing every variation in rainfall, elevation, and physical surroundings. The most valuable results of these collections were seen in the study of birds. It was found in general that each bird of the Atlantic States had its counterpart on the prairies, the sage plains, the mountains, and the Pacific slope. Differences were carefully sought for and found, for the followers of Professor Baird allowed nothing to escape their analysis. There were differences in size, in form and colour-slight in degree, but nevertheless really existing-and these were made the basis of as many distinct species. Still further 
studies increased the number of these species, until at last a large proportion of our birds were represented by Eastern, Western, sage brush, and prairie species. Sometimes these closely connected forms were distinguishable at first sight, as in the case of the yellowhammer and its double, the red-shafted flicker; in other cases baffling the most skilful, as with the two species of crow-blackbird.

An illustration of these forms and their relation may be taken from the common shore lark and its varieties, although it is fair to say that some of these variations have never been regarded as species.

The shore lark or horned lark (Otocoris alpestris), ranges widely over the colder and open parts of Europe, The shore larks. Asia, and America. The common form, called alpestris, is familiar to most of us. In the northwestern region, as far south as Utah, is another form, equally large but paler in colour (leucolama). In the prairie region the lark is of the ordinary colour but smaller (praticola). In the sage plains it is a similarly small but pale lark, with brighter yellow in its throat; this is arenicola. In Texas the bird is still smaller and grayer (giraudi) ; while the small form found in New Mexico and Arizona has its plumage strongly washed with red; this is chrysolama. In the interior of California the shore larks are still smaller and redder (variety rubea), while northward and coastwise appears a small lark with more streaked plumage-this is strigata. All these can be generally recognised by an expert ornithologist, and doubtless a closer analysis would reveal the basis for still finer subdivisions.*

* In the Auk for April, I8go, is an essay on the Horned Larks of North America, by Jonathan Dwight, Jr. Mr. Dwight's conclusions are based on two thousand and twelve specimens; those of Mr. H. W. Henshaw, above given, on three hundred and fifty. 
In $187 \mathrm{I}$, Dr. Joel A. Allen published his masterly paper on the Mammals and Winter Birds of Florida. This memoir has had the practical effect Work of Dr. J. A. Allen. of making all our ornithologists, for the most part against their will, believers in the theory of derivation of species. Dr. Allen took up, as a matter of serious study, the variations in individual birds. He showed that the variation of individuals of the same species was far greater than had been supposed, and that the characters relied upon to distinguish species were often due to slight increase in these variations. For example, in Northern birds the bodies would be larger, the bills smaller than in birds of the same species from the South, and the coloration of birds was often directly related to the degree of rainfall. $\mathrm{He}$ showed, in brief, that each one of these many variations must be held to define a distinct species, or else that the number of species of American birds would have to be greatly reduced and the range of variation inside the species would need to be correspondingly extended.

This claim for attention on the part of the despised variety produced much consternation among students of Species defined by missing links.

birds. But facts must be recognised, and the final result has been that we have now extended our idea of each species until it is broad enough to include all that we know of intermediate and varying forms. But these intermediate forms must be known, not guessed at, before the status of a species is questioned. When a hiatus appears, whether existing either in fact or in our material for

To the forms mentioned above Mr. Dwight adds var. adusta, small and "scorched pink" in general hue, from southern Arizona and northern Mexico; var. menilli, large and dusky, in Idaho and neighbouring regions; and var. pallida, very small and pale, from Lower California. 
study, there we put our line of definition. "We can only predicate and define species at all," says Dr. Coues, "from the mere circumstance of missing links. Species are the twigs of a tree separated from the parent stem. We name and arrange them arbitrarily, in default of means of reconstructing the whole tree in accordance with Nature's ramifications." *

What is true of birds is equally the case with other groups of animals. Continued explorations bring to light each year new species of American fishes, but the number of new forms discovered each year is usually less than the number of old supposed species which are found to intergrade with each other, and have so become intenable.

There is the closest possible analogy between the variations of species of animals or plants in different districts and that of words in different Analogy between variations of species and words. languages. The language of any people is not a unit. It is made up of words which have at various times and under various conditions come into it from the speech of other people. The grammar of a language is an expression of the mutual relations of these words. The word as it exists in any one language represents the species. Its cognate or its ancestor in any other language is a related species. The words used in a given district at any one time constitute its philological fauna.

* Dr. Allen says: “We arbitrarily define a species as a group of individuals standing out distinct and disconnected from any similar group within which, though occupying different parts of the common habitat, we recognise other forms characteristic of and restricted to particular areas. These reach a maximum degree of differentiation at some point in the habitat, and thence gradually shade into other non-specific forms geographically contiguous."-The Auk, January, r8go, p. 7. 
There is a strruggle for existence between words as among animals. For example, the words begin and commence, Saxon and French, are in the English language constantly brought into competition. The fittest, the one that suits English purposes best, will at last survive. If both have elements of fitness, the field will be divided between them. The silent letters in words tell their past history, as rudimentary organs tell what an animal's ancestry has been. This analogy, of course, is not perfect in all regards, as the passing of words from mouth to mouth is not homologous with the generation of animals.

We may illustrate the formation of species of animals by following any widely used word across Europe. Thus the Greek aster becomes in Latin and Italian stella; hence the Spanish estrella and the French etoile. In Germany it becomes Stern, in Danish Stjern; whence the Scottish starn and English star.

In like manner, the name cherry may be traced from country to country to which it has been taken in cultivation. Its Greek name, Kerasos, becomes cerasus, ceresia, ceriso, cereso, cérise, among the Latin nations. This word is shortened to Kirsch and Kers with the people of the North. In England, cherys, cherry, are obviously derived from cérise.

The study of a fauna or a flora as a whole is thus analogous to the study of a living language. The evoA fauna like a language.

lution of a language corresponds to the history of the life of some region. Philology, systematic zoology, and botany are alike intimately related to geography. The spread of a language, like the spread of a fauna, is limited by natural barriers. It is the work of civilization to break down these barriers as limiting the distribution of civilized man. The dominant languages cross these barri- 
ers with the races of men who use them, and with them go the domesticated animals and plants and the weeds and vermin man has brought unwillingly into relations of domination.

The process of natural selection has been summed up in the phrase "survival of the fittest." This, howThe survival of the existing. ever, tells only part of the story. "Survival of the existing" in many cases covers more of the truth. For in hosts of cases the survival of characters rests not on any special usefulness or fitness, but on the fact that individuals possessing these characters have inhabited or invaded a certain area. The principle of utility explains survivals among competing structures. It rarely accounts for qualities associated with geographic distribution.

The nature of the animals which first colonize a district must determine what the future fauna shall be. From their specific characters, which are neither useful nor harmful, will be derived for the most part the specific characters of their successors.

It is not essential to the meadow lark that he should have a black blotch on the breast or the outer tailfeather white. Yet all meadow larks have these characters just as all shore larks have the tiny plume behind the ear. Those characters of the parent stock, which may be harmful in the new relations, will be eliminated by natural selection. Those especially helpful will be intensified and modified, but the great body of characters, the marks by which we know the species, will be neither helpful nor hurtful. These will be meaningless streaks and spots, variations in size of parts, peculiar relations of scales or hair or feathers, little matters which can neither help nor hurt, but which have all the persistence heredity can give.

The species of animals change with space and change 
with time. They change with space because, as they move over the globe, with distance comes barriers, with barriers isolation, and any degree of isolation brings some change of conditions. This means, sooner or later, a distinction of species.

Species change with time, because time brings changes in conditions. Epoch-making events of one sort or another come in to break even the most How species change with time. monotonous existence. If time could flow on evenly there need arise no change in life, adaptation being once established. If space were absolutely uniform without barriers or variation of conditions, life would flow on as uniformly. Where there is most monotony in conditions, as in the depths of the sea, there is least change in life, least formation of new species, and least tendency to progress through natural selection.

Similar to geographical isolation in its nature and effects is physiological isolation. This appears in the dePhysiological isolation. velopment, in isolated races, of antipathies which serve as barriers to prevent the interbreeding with allied races or species. This condition among animals is the homologue of race hostility among men. Such a feeling of mutual aversion, whether accompanied by anatomical distinctions or not, must be at times a strong factor in the differentiation of species.

The study of the problems of geographical distribution is possible only on the theory of the derivation of Meaning of facts species. If we view all animals and of distribution.

plants as the results of special creations in the regions assigned to them, we have, instead of laws, only a jumble of arbitrary and meaningless facts. We have been too fully accustomed to the recognition of law to believe that any facts are arbitrary 
and meaningless. We know no facts which lie beyond the realm of law. I may close with the language of Asa Gray:

"When we gather into one line the several threads of evidence of this sort to which we have here barely alluded we find that they lead in the same direction with the views furnished by [other lines of investigation]. Slender indeed each thread may be, but they are manifold, and together they bind us firmly to the doctrine of the derivation of the species." 


\section{VIII.}

\section{LATITUDE AND VERTEBRÆ.}

\section{A STUDY IN THE EVOLUTION OF FISHES.}

IN this paper is given an account of a curious biological problem and of the progress which has been made toward its solution. The discussion may have a certain popular interest from the fact that it is a type of many problems in the structure and distribution of animals and plants which seem to be associated with the laws of evolution. In the light of these laws they may be more or less perfectly solved. On any other hypothesis than that of the derivation of species the solution of the present problem, for example, would be impossible. On the hypothesis of special creation a solution would be not only impossible but inconceivable.

It has been known for some years that in several groups of fishes (wrasse fishes, flounders, and "rock cod," for example) those species which

Northern fishes have most vertebræ. inhabit northern waters have more vertebræ than those living in the tropics. Certain arctic flounders, for example, have sixty vertebræ; tropical flounders have, on the average, thirty. The significance of this fact is the problem at issue. In science it is assumed that all facts have significance, else they would not exist. It becomes necessary, then, to find out first just what the facts are in this regard. 
Going through the various groups of non-migratory marine fishes we find that such relations are common. In almost every group the number of vertebræ grows smaller as we approach the equator, and grows larger again as we pass into southern latitudes.

It would be tedious to show this here by statistical tables, but the value of generalization in science depends on such evidence. This proof I have elsewhere* given in detail. Suffice it to say that, taking an average netful of fishes of different kinds at different places along the coast, the variation would be evident. At Point Barrow or Cape Farewell or North Cape a seineful of fishes would perhaps average eighty vertebræ each, the body lengthened to make room for them; at Sitka or St. Johns or Bergen, perhaps, sixty vertebræ; at San Francisco or New York or St. Malo, thirty-five; at Mazatlan or Pensacola or Naples, twenty-eight; and at Panama or Havana or Sierra Leone, twenty-five. Under the equator the usual number of vertebræ in shore fishes is twenty-four. Outside the tropics this number is the exception. North of Cape Cod it is virtually unknown.

The next question which arises is whether we can find other conditions that may affect these numbers. These readily appear. Fresh-water fishes Fewest vertebræ in shore fishes of the tropics.

have in general more vertebræ than saltwater fishes of the same group. Deepsea fishes have more vertebræ than fishes of shallow waters. Pelagic fishes and free-swimming fishes have more than those which live along the shores,

* In a more technical paper on this subject entitled Relations of Temperature to Vertebræ among Fishes, published in the Proceedings of the United States National Museum for 1891, pp. 107120. Still fuller details are given in a paper contained in the Wilder Quarter-Century Book, 1893 . 
and more than localized or non-migratory forms. * The extinct fishes of earlier geological periods had more vertebræ than the corresponding modern forms which are regarded as their descendants. To each of these generalizations there are occasional partial exceptions, but not such as to invalidate the rule.

All these effects should be referable to the same group of causes. They may, in fact, be combined in one statement. All other fishes have a larger number of vertebræ than the marine shore fishes of the tropics. The cause of the reduction in numbers of vertebræ must therefore be sought in conditions peculiar to the tropical seas. If the retention of the primitive large number is in any case a phase of degeneration, the cause of such degeneration must be sought in the colder seas, in the rivers, and in oceanic abysses. What have these waters

* This is especially true among those fishes which swim for long distances, as, for example, many of the mackerel family. Among such there is often found a high grade of muscular power, or even of activity, associated with a large number of vertebræ, these vertebræ being individually small and little differentiated. For long-continued muscular action of a uniform kind there would be perhaps an advantage in the low development of the vertebral column. For muscular alertness, moving short distances with great speed, the action of a fish constantly on its guard against enemies or watching for its prey, the advantage would be on the side of few vertebræ. There is often a correlation between the freeswimming habit and slenderness and suppleness of body, which again is often dependent on an increase in numbers of the vertebral segments. These correlations appear as a disturbing element in the problem rather than as furnishing a clew to its solution. In some groups of fresh-water fishes there is a reduction in numbers of vertebræ, not associated with any degree of specialization of the individual bone, but correlated with simple reduction in size of body. This is apparently a phenomenon of degeneration, a survival of dwarfs where conditions are unfavorable in full growth. 
in common that the coral reefs, rocky islands, and tide pools of the tropics have not?

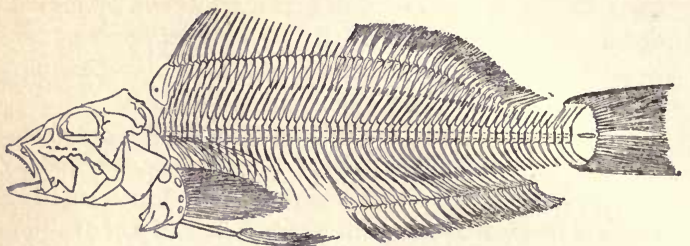

FIG. 16.-Skeleton of the spotted greenling (Hexagrammos decagrammus). From nature, by W. S. Atkinson. A northern fish, with vertebræ numerous and small.

In this connection we are to remember that the fewer vertebræ indicates generally the higher rank. When

Fewer vertebræ indicates greater specialization. vertebræ are few in number, as a rule each one is larger. Its structure is more complicated, its appendages are larger and more useful, and the fins with which it is connected are better developed. In other words, the tropical fish is more intensely and compactly a fish,

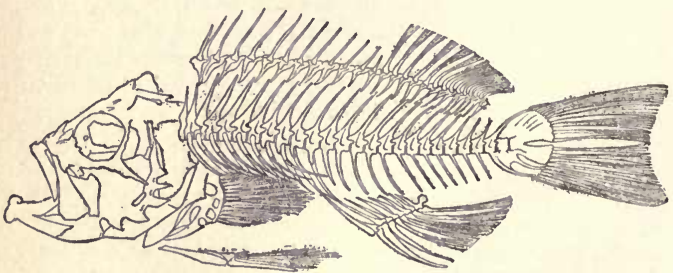

Fig. 17.-Skeleton of the scarlet rock-fish (Sebastodes miniatus). From nature, by W.S. Atkinson. A species of temperate waters; the vertebræ in moderate number.

with a better fish equipment, and in all ways better fitted for the business of a fish, especially for that of a fish that stays at home. 
In my view the reduction in number and increase of importance of the individual vertebræ are simply part of a process we may call ichthyization, the work of making a better fish. Not a better fish for man's purposes-for Nature does not care for man's purposesbut a better fish for the purposes of a fish. The competition in the struggle for existence is the essential cause of the change. In the centre of competition no species can afford to be handicapped by a weak back-

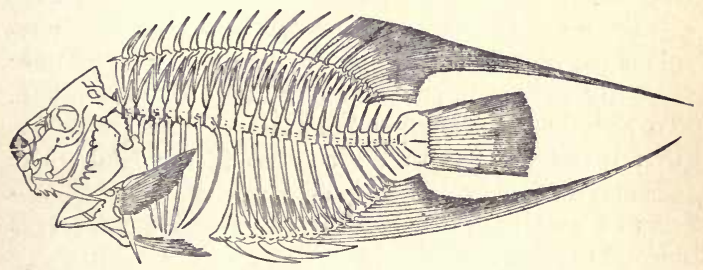

FIG. 18.-Skeleton of angel fish (Angelichthys ciliaris). From nature, by W. S. Atkinson. A tropical species; the vertebræ few and large.

bone and redundant vertebræ. Those who are thus weighted can not hold their own. They must change or perish.

The influence of cold, darkness, monotony, and isolation is to limit the struggle for existence, and there-

Coral reefs the centre of fish competition. fore to prevent its changes, preserving through the conservation of heredity the more remote ancestral conditions, even though they carry with them disadvantages and deficiencies. The conditions most favourable to fish life are among the rocks and reefs of the tropical seas. About the coral reefs is the centre of fish competition. A coral archipelago is the Paris of fishes. In such regions is the greatest variety of surroundings, and 
therefore the greatest number of possible adjustments. The struggle is between fish and fish, not between fishes and hard conditions of life. No form is excluded from the competition. Cold, darkness, and foul water do not shut out competitors, nor does any evil influence sap the strength. The heat of the tropics does not make the water hot. It is never sultry nor laden with malaria. The influence of tropical heat on land ahimals is often to destroy vitality and check activity. It is not so in the sea.

From conditions otherwise favourable in arctic regions the majority of competitors are excluded by their inability to bear the cold. River life is life in isolation. To aquatic animals river life has the same limitations that island life has to the animals of the land. The oceanic islands are far behind the continents in the process of evolution. In like manner the rivers are ages behind the seas.

Therefore the influences which serve as a whole to intensify fish life, and tend to rid the fish of every character or structure it can not "use in its business," are most effective along the shores of the tropics. One phase of this is the reduction in numbers of vertebræ, or, more accurately, the increase of stress on each individual bone.

Conversely, as the causes of these changes are still in operation, we should find that in cold waters, deep waters, dark waters, fresh waters, inclosed waters, and in the waters of past geological epochs, the process would be less complete, the numbers of vertebræ would be larger, while the individual vertebræ remain smaller, less complete, and less perfectly ossified.

This, in a general way, is precisely what we do find in examining the skeletons of a large variety of fishes. 
Another phase is the process of cephalization, the process by which the head becomes emphasized and the shoulder bones and other structures be-

Cephalization through competition. come connected with it or subordinated to it. Still another is the reduction and change of the swim bladder and its utter loss of the function of lung or breathing organ which it occupied in the ganoid ancestors of modern fishes.

The life of the tropics, so far as fishes are concerned, offers many analogies to the life of cities, viewed from the standpoint of human development. Analogy of the tropical waters to cities of men.

In the cities in general, the conditions of individual existence for the man are most easy, but there also competition of life is most severe. The struggle for existence is not a struggle with the forces and conditions of Nature. It is not a struggle with wild beasts, unbroken forests, or stubborn soil, but a competition between man and man for the opportunity of living.

It is in the city where the influences which tend to modernization and concentration of the characters of the species go on most rapidly. It is adaptation or death to each individual in the city: every quality not directly useful tends to become lost or atrophied.

Conversely, it is in the "backwoods," the region farthest from human conflicts, where primitive customs, antiquated peculiarities, and useless traits are longest and most persistently retained. The life of the "backwoods" may be not less active or vigorous, but it will lack specialization. It is from the unused possibilities of the "backwoods" that the progress of the future comes. The high specialization of favoured regions unfits its subjects for life under changed conditions. The loss of muscular power is often one of the results of skeletal specialization. 
The coral reef is the metropolis of the fish. The deep sea, the arctic sea, and the isolated rivers-these are the ichthyological backwoods.

An exception to the general rule in regard to the numbers of vertebræ is found in the case of the eel. Origin of eels.

Eels inhabit nearly all seas, and everywhere they have many vertebræ. The eels of the tropics are at once more specialized and more degraded. They are better eels than those of northern regions, but, as the eel is a degraded type, they have gone further in the loss of structures in which this degeneration consists.

It is not well to push this analogy too far, but perhaps we can find in the comparison of the tropics and the cities some suggestion as to the development of the eel.

In the city there is always a class which follows in no degree the general line of development. Its members are specialized in a wholly different way. By this means they take to themselves a field which others have neglected, making up in low cunning what they lack in humanity or intelligence.

Thus, among the fishes, we have in the regions of closest competition this degenerate and non-fishlike type, lurking in holes among the rocks, or creeping in the sand; thieves and scavengers among fishes. The eels thus fill a place otherwise left unfilled. In their way they are perfectly adapted to the lives they lead. A multiplicity of vertebral joints is useless to the typical fish, but to the eel, strength and suppleness are everything. No armature of fin or scale or bone is so desirable as its power of escaping through the smallest opening. 


\section{IX.}

\section{EVOLUTION OF FOSSIL CEPHALOPODA.}

By JAMEs PERrin SMITH.

Most of the paleontologic contributions to the evidence of evolution were gathered before the time of

General evidence of paleontology.

Darwin, and are therefore all the more trustworthy because the naturalists that gathered them were not evolutionists. It is indeed remarkable that their classifications have been so little changed by the introduction of the theory of evolution into the study of biology. Since this is the case the paleontologic record ought to show the order of appearance of genera in time, and their genetic relationship. It does do this in a general way. Thus in the echinoderms we have the cystoids, apparently the primitive stock, beginning in the Cambrian and disappearing in the Carboniferous; the blastoids, somewhat higher, began in the Upper Silurian and disappeared in the Carboniferous; the true crinoids, or sea lilies, began in the Lower Silurian and survived until the present day. Asteroids we know from the Cambrian on, and echinoids, or sea urchins, from the Lower Silurian until now.

Although their succession in time suggests genetic relationships, the crinoids, and especially the cystoids, being the most primitive type, the first known of the three great groups are apparently as widely separated from each other as they now are. Either they are par- 
allel developments from a common stock, or else the separation from the oldest stock of crinoids took place in the misty pre-Cambrian time.

The vertebrates, too, show evolution in a general way in the appearance of types, for we find fishes from the Lower Silurian on; at first only placoderms, bonyplated fishes, then upward by degrees to the teleosts (scale fish with bony skeleton), which began in the Upper Jura. Amphibians had branched off from the fish stock by the end of the Devonian, genuine reptiles from the amphibians by the end of Carboniferous time. Mammals appeared first in the Trias, probably as descendants from the amphibian stock. The first birds we find in the Upper Jura as transitions from reptiles.

The method used by most naturalists in the study of phylogeny has been a comparison of a series of adults from successive geologic horizons, together with a study of present and past distribution and migration of animals. The results of this are seen in all our classification and in all family trees. Such work as Marsh's origin of the horse, Cope's phylogeny of the reptiles, Baur's contributions to the origin of the mammals, and many others, abundantly justify this method of research.

But interesting and valuable as are the investigations in phylogeny made in this way, such genealogies can not, as a matter of course, be more than approximate, for we have nowhere a uniform succession of rocks, and nowhere an unbroken genetic series. Each region has often changed, belonging now to one faunal province, now to another, each great change in faunal geography showing some physiographic revolution here or elsewhere. Thus the local series is broken and filled out from other regions, species usually being classed together because of mere resemblance, while their real relationship is unknown. 
If the geologic record is incomplete, the biologic record is still more so; the beginnings of things are lacking just where we should most like Incompleteness of the record. to see them. Either most of the branching stocks were incapable of being preserved as fossils, or we have yet to find the strata in which they may be preserved. In the Cambrian the divergence was already complete, all the subkingdoms were present except the vertebrates, and they, too, probably existed at that time, for highly specialized placoderm fishes have been found in the Lower Silurian. The brachiopods had already branched out into articulates and inarticulates, the molluscs into pelecypods, gastropods, and cephalopods. The crustaceans were already represented by phyllocarids, trilobites, and ostracods, widely divergent types. Even at the base of the Cambrian beds all these animals, especially the trilobites, went through many larval changes before they reached maturity, thus indicating a long family history of numerous pre-existing unknown ancestral genera.

LAW OF ACCELERATION OF DEVELOPMENT.

Since the geologic record is so badly broken, and since modern faunas and floras are but the topmost branches of a tree whose stock is only partly known, the early naturalists were merely groping in the dark in their efforts to get a natural classification. There was, however, a glimmer of light, although scarcely heeded. No one man seems to have been the discoverer of the law of acceleration of development, but, like the idea of evolution, it was in the air, and disclosed itself in various ways to the prophetic vision of seekers after truth. J. F. Meckel,* a German naturalist, seems to have been the first to give scientific expression to the

* Syst. Vergl. Anat., i, Theil, Halle, I821. 
biogenetic law, in his formula, "Gleichung zwischen der Entwicklung des Embryo und der Thierreihe," comparison of development of the embryo with the race of animals. But Louis Agassiz, although not the discoverer, was undoubtedly the first to use the law as an aid in the systematic study of biology. While he regarded the various genera, not as ancestors and descendants, but as progressive steps in creation, still he saw the analogy between the stages of growth of the individual and these progressive steps. It was reserved for Alpheus Hyatt to formulate the law and to strengthen theory with practical examples based on the study of cephalopods. ${ }^{*}$ In his later papers Professor Hyatt has given a more exact and comprehensive definition of the law of acceleration or tachygenesis: "All modifications and variations in progressive series tend to appear first in the adolescent or adult stages of growth, and then to be inherited in successive descendants at earlier and earlier stages, according to the law of acceleration, until they either become embryonic or are crowded out of the organization and replaced in the development by characteristics of later origin." $\dagger$ A still more definite statement by the same author is the following: "The substages of development in ontogeny are the bearers of distal ancestral characters in inverse proportion and of proximal ancestral characters in direct proportion to their removal in time and position from the protoconch or last embryonic stage." $\ddagger$ Since Hyatt's first paper the

* A. Hyatt. Mem. Boston Soc. Nat. Hist., vol. i, 1866-'67 ; and Proc. Boston Soc. Nat. Hist., vol. i, I866, Parallelisms of Individual and Order among the Telrabranchiate Mollusks.

†A. Hyatt. Smithsonian Contribution to Knowledge, No. 673, Genesis of the Arietidæ, Preface, p. ix.

$\ddagger$ Proc. Am. Phil. Soc., vol. xxxii, No. 143, A. Hyatt, Phylogeny of an Acquired Characteristic, p. 405. 
law has been rediscovered and renamed by Haeckel,* "das biogenetische Grundgesetz" and by Würtenberger. $\dagger$ But these naturalists, instead of adding anything to Hyatt's definition, have failed to reach its clearness and simplicity. The only real addition that has been made is Cope's idea of retardation, $\downarrow$ by which is explained the separation in the ontogeny of the descendant of characters that occurred simultaneously in the ancestor. Cope says: "The acceleration in the assumption of a character, progressing more rapidly than the same in another character, must soon produce, in a type whose stages were once the exact parallel of a permanent lower form, the condition of inexact parallelism. As all the more comprehensive groups present this relation to each other, we are compelled to believe that acceleration has been the principle of their successive evolution during the long ages of geologic time. Each type has, however, its day of supremacy and perfection of organism, and a retrogression in these respects has succeeded. This has no doubt followed a law the reverse of acceleration, which has been called retardation. By the increasing slowness of the growth of the individuals of a genus, and later and later assumption of the characters of the latter, they would be successively lost." \#

By a proper application of the law of acceleration as defined by Hyatt and modified by Cope, all the facts of biology may be explained; there is no such thing as "falsification of the record." But as yet the law has had no great effect in classification, for most paleon-

* Morphologie der Organismen, vol. ii ; and Anthropogenie, 1874 .

$\nmid$ Ausland, 1873, and Studien über die Stammesgeschichte der Ammoniten, I88o.

$\ddagger$ Origin of the Fittest.

\# Origin of the Fittest, p. I42. 
tologists have not approached their work from the biologic side, and biologists have been equally neglectful of the results attained by paleontology. A distinguished zoologist once said to the writer, on being shown an ontogenetic series of ammonites, and the conclusions reached, "It is all beautiful, but almost too good to be true." In paleontology it is especially true that a naturalist may be a specialist in the fauna of one age, and know little of that of another. Hence the animals of various periods have been classified according to varying standards, all artificial. The only cure for these discrepancies is study of ontogeny, and comparison of stages of growth of the individual with ancestral genera. This will also prevent the description of supposedly new genera and species based on immature specimens, as has so often been done. The writer remembers once collecting numerous Ceratites in the Karnic limestone of the California Trias, much to his astonishment, for they ought not to occur so high up. He afterward found, however, that they were not adults, but adolescent ceratitic stages of Arpadites; a similar case was the finding in the same horizon a Tirolites above its proper range, but it turned out to be the young of a Trachyceras that persisted unusually long in the Tirolites stage. At that time there was nothing in the description of these genera or any of their species to guide one, and so their ontogeny had to be worked out independently. But there is nothing in the description of almost any fossil genera and species to prevent just such mistakes, and they are constantly being made.

By careful study of ontogeny in comparison with phylogeny the paleontologist can correlate correctly fossil beds where even all the genera and species are new; he can even prophesy concerning the occurrence of unknown genera in certain horizons when he finds 
their minute counterparts in youthful stages of later forms; in fact, he could of ten furnish just as exact a description of the form as if he had the adult genus before him.

\section{NOMENCLATURE OF STAGES OF GROWTH.}

In order to correlate ontogenetic stages with the generic changes seen in the development of the race it is necessary to have an exact scientific nomenclature. The most satisfactory is that given by Professor Hyatt in Phylogeny of an Acquired Characteristic.*

\section{Table of Ontogenetic Stages.}

Stages. Stages. Substages. Comparison with phylogeny.

Embryonic (I) Embryonic $\left\{\begin{array}{l}\text { Protembryo } \\ \text { Mesembryo } \\ \text { Metembryo } \\ \text { Neoembryo } \\ \text { Typembryo } \\ \text { Phylembryo }\end{array}\right\}$

Larval (2) Nepionic

$\left\{\begin{array}{l}\text { Ananepionic } \\ \text { Metanepionic } \\ \text { Paranepionic }\end{array}\right\}$

Adolescent (3) Neanic

$\left\{\begin{array}{l}\text { Ananeanic } \\ \text { Metaneanic } \\ \text { Paraneanic }\end{array}\right\}$ Phyloneanic

Adult

(4) Ephebic

$\left\{\begin{array}{l}\text { Anephebic } \\ \text { Metephebic } \\ \text { Parephebic }\end{array}\right\}$ Phylephebic

Senile

(5) Gerontic

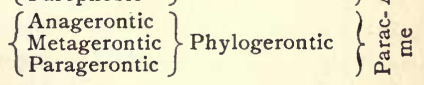

With the embryonic stage the paleontologist can do nothing, except the very last substage or phylembryo, when the Mollusca, Brachiopoda, and other groups begin to secrete their shells; but all the later stages are easily accessible in well-preserved material.

The best example of correlation of ontogenetic

* Proc. Am. Phil. Soc., vol. xxxii, No. I43, pp. 391 and 397. 
stages with phylogeny is the genealogy of Medlicottia, worked out by Karpinsky, * who has shown that the Carboniferous genus Pronorites goes through the following stages: latisellate protoconch, phylembryonic; with the second suture it reaches the Anarcestes stage, nepionic; about the end of the first revolution the Ibergiceras stage begins, paranepionic; second revolution shows the Paraprolecanites stage, neanic; on the third whorl begins the Pronorites stage, adult. $f$ Thus with regard to Pronorites the genus Anarcestes is phylonepionic, Ibergiceras is phyloparanepionic, Paraprolecanites is phyloneanic. In the same work Karpinsky has shown that Medlicottia is a direct descendant of Pronorites, and in its development goes through all the stages of the ancestral genus and adds several more. The first revolution of Medlicottia could not be studied, but on the second revolution was seen the Ibergiceras stage, metanepionic; on the third whorl the Paraprolecanites stage, paranepionic; at the end of the third whorl the Pronorites stage, beginning of the neanic; on the fourth whorl the Sicanites stage, end of the neanic; on the fifth whorl the Promedlicottia stage, anephebic; and lastly, at end of the fifth whorl, Medlicottia, adult in characteristics, though not yet in size.

\section{PALEONTOGENY.}

Just as biologists are turning more and more to the study of morphology and ontogeny, so the paleontolo-

General statement.

gist is striving to find out the life-history of fossil species-paleontogeny. It will surprise many to learn that this can be done, but in reality the development of many fossil

* Mem. Acad. Imper. Sci. St. Petersburg, vii ser., tome xxxvii, No. 2, Ammoneen der Artinsk-Stufe.

† See Plate IV, Fig. 9. 
species is known more accurately than that of most living forms.

Vertebrates are out of the question for this sort of work, being too highly accelerated in their development ; the stages that might be useful in phylogenetic study are gone through before the animal is capable of being preserved as a fossil. In the cœlenterates the relations between Cenozoic and Paleozoic forms are not understood, and the ontogeny of the group does not show changes that are striking enough to throw much light on their history. In the Echinodermata poor preservation of fossil forms, especially of the young, makes ontogenetic study very difficult, but Dr. R. T. Jackson* has been able, by a study of development of plates of the sea urchins, to throw some light on the phylogeny of the group. The only crinoid of which the development is known is Antedon, which, unlike all the others, is freeswimming when adult, although attached by a jointed stem as a larva. The investigations of Wyville Thomson, Bury, and others, show that the embryo is like the larva of certain annelid worms; after a short free stage this embryo settles down, attaches itself to some object, begins to secrete a stem and jointed calyx, or body cup. In this stage it is like the Ichthyocrinoidea of the Paleozoic. Then certain of the plates are resorbed, the character of the jointed stem changed, and the animal is like Pentacrinus of the Mesozoic and Cenozoic. At the end of its larval period Antedon frees itself from its fixed position, loses all resemblance to Pentacrinus, and for the rest of its life is a free-swimming pelagic form.

The most satisfactory groups for this work are the Brachiopoda, the Mollusca, and the Crustacea.

* Studies of Palæechinoidea. Bull. Geol. Soc. Amer., vol. vii, pp. I 7I-254. 
Brachiopoda.-The brachiopods have this decided advantage, that they can be hatched in marine laboratories, and the various stages studied from the egg up, as has been done by Brooks, Kovalevski, Lacaze-Duthiers, Morse, and Shipley, with the genera Cistella, Glottidia, Lacazella, Liothyrina, and Terebratulina. But it was reserved for the paleontologists Beecher, J. M. Clarke, and Schuchert to correlate the ontogeny of living forms with ancestral genera, and give a biogenetic classification of the Brachiopoda* based on ontogenetic study.

In living specimens the subdivisions of the embryonic stage, protembryo, mesembryo, neoembryo, and typembryo may easily be made out, but since these are shellless the work of the paleontologist begins with the phylembryonic substage, when the shell gland secretes the protegulum. From this upward the paleontologist works on equal terms with the zoölogist, for the succeeding stages are capable of preservation, and may be compared with ancestral genera. Beecher and Schuchert $\uparrow$ have demonstrated that the Ancylobranchia (Terebratuloids) all go through a primitive Centronelliform stage, and that the Helicopegmata (spire-bearers) do the same, and are for a while genuine Ancylobranchia. Schuchert's classification of the Brachiopoda, published in Eastman's translation of Zittel's Text-Book of Paleontol-

* For correlation of stages of growth with generic changes, and for the literature on ontogeny and phylogeny of Brachiopoda, see papers by Dr. C. E. Beecher, Amer. Jour. Sci., vol. xliv, August, 1892, Development of Brachiopoda, Part II ; and Trans. Connecticut Acad. Sci., vol. ix, March, 1893, Revision of the Families of Loop-bearing Brachiopoda; and The Development of Terebratalia Obsoleta Dall.

† Proc. Biol. Soc. Washington, vol. viii, July 13, 1893. Development of the Brachial Supports in Dielasma and Zygospira. 
ogy, 1896 , may be taken as strictly biogenetic so far as the data now at hand make such a thing possible.

Crustacea.-The only Crustacea that are useful for the study of paleontogeny are the trilobites, and since they are all extinct without leaving any descendants, modern biology can give us little help. We are thus to a greater extent than with the Brachiopoda thrown entirely on the ontogeny of fossils, and in this case, too, the various stages must be worked out from separate individuals. Many naturalists, beginning with Barrande, have worked on the ontogeny of trilobites, have described various stages, sometimes as larvæ, sometimes as adult genera or species, but they met with seemingly insuperable difficulties in correlating these stages with the genealogy. Dr. C. E. Beecher, however, has overcome these difficulties, presenting his results in a recent paper on The Larval Stages of Trilobites, * in which he shows that all trilobites go through a phylembryonic stage, protaspis, homologous to the protonauplius of the higher Crustacea. While no known genera are exactly like the protaspis, still there are several that retain many of its features. After the protaspis stage the various groups of genera develop in different directions, . but all go through larval stages analogous to generic changes in their group. The protaspis itself of the later groups becomes more complicated by acceleration of development, but always retains its essential features. By means of this study Dr. Beecher has been able to give the beginning of a truly genetic classification of trilobites. $\dagger$

Mollusca.-Of the Mollusca only the Pelecypoda and the Cephalopoda are of use to the student of paleontog-

* Amer. Geol., vol. xvi, September, r895.

† Amer. Jour. Sci., February and March, i897. Outline of a Natural Classification of Trilobites." 
eny, for of the Gastropoda we have not as yet a biogenetic classification, and the larval stages even of living forms have not been well studied.

Pelecypoda.-Almost all that has been done in comparing genera of Pelecypoda with stages of growth is the work of Dr. R. T. Jackson, * who has shown that they all go through a phylembryonic stage, prodissoconch, analogous to the protegulum of Brachiopoda, the protoconch of Cephalopoda and Gastropoda, and the protaspis of trilobites. The prodissoconch is a straight-hinged, two-muscled, smooth-shelled, bivalve stage, corresponding to the nuculoids, the primitive radicle stock of pelecypods. Even the monomyarian oyster goes through this dimyarian stage.

Cephalopoda.-The living dibranchiate cephalopods, Octopus, Loligo, Spirula, Argonauta, and other naked forms, are scarcely capable of preserving their larval stages as fossils; but what is known of their development points to a tetrabranch ancestry, as, for example, the rudimentary second pair of gills in some forms.

The tetrabranchiate cephalopods, of which the Nautilus is the only living representative, are entitled to speak with especial authority on evolution, for near the end of a long and varied family history they have gone through all the changes of progression and retrogression of which the group is capable. Also a much more perfect record has been kept of them in the rocks than of any other class of animals, so that practically all the sorts of tetrabranchs that existed are known.

Their remote ancestry is unknown, but indications seem to point to Tentaculites as the radicle of the stock of cephalopods, although this is no great help, for the systematic position of Tentaculites, a supposed pteropod,

* Mem. Boston Soc. Nat. History, vol. iv, No. 8, I8go. Phy. logeny of the Pelecypoda. 



\section{EXPLANATION OF THE FIGURES.*}

Plate I.

All figures on this plate are thirty times enlarged.

Glyphioceras incisum HyатT.

Figs. I and 2.-Protoconch. I, from above; 2, from front. Diameter, .46 $\mathrm{mm}$.

Figs. 3, 4, and 5.-Protoconch of same or a nearly related species from Scott County, Arkansas. 3, from above ; 4 , from front ; 5 , from side.

Figs. 6, 7, and 8.-Protoconch with first two sutures. 6, from above; 7 , from front ; 8 , from side.

Figs. 9 and ro.-Larval stage, diameter of .74 mm., protoconch and one half of first whorl, showing the first four sutures, from phylembryonic to the paranepionic substage. 9, from side, 10, from front.

Figs. II and 12.-Larval stage, diameter of $.92 \mathrm{~mm}$., first whorl, showing first eight sutures, and transitions from the metanepionic (Anarcestes stage), through paranepionic (Tornoceras stage) to ananeanic (Prionoceras stage). II, from front ; I2, from side.

* From The Development of Glyphioceras and the Phylogeny of the Glyphioceratidx, by J. P. Smith. Proc. Calif. Acad. Sci., third series, vol. i, Geology, No. 3, Plate XIII. 
PLATE I.

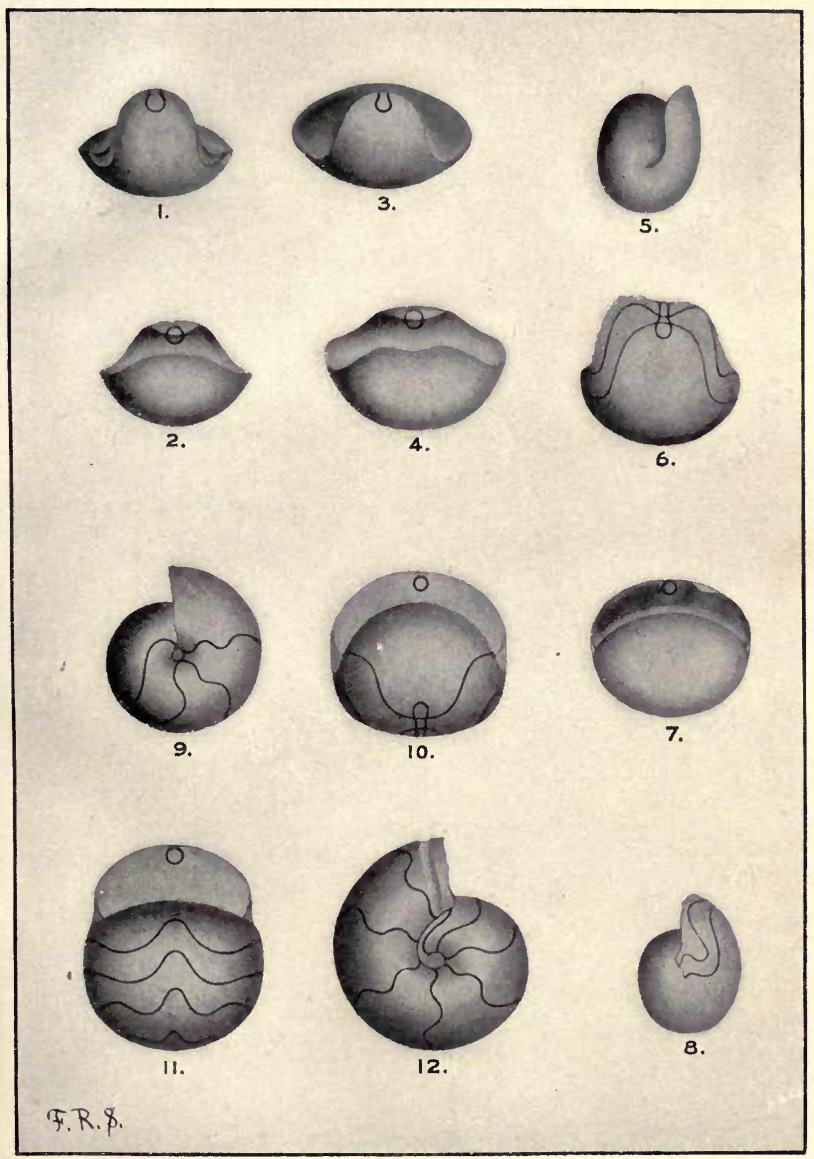


is in doubt. The first nautiloid known occurs in Cambrian strata, and belongs to the straight-shelled Orthoceras type, which is the radicle of the group. Endoceras, the most primitive of orthoceran forms, prevails in the Lower Silurian, but here come in also curved forms, at first sparingly, then later abundantly. The simple unspecialized orthoceran type (of which a member is figured on Plate V, Fig. r), survived throughout the entire Paleozoic, and finally disappeared near the end of the Trias. The first of the curved forms departed but little from their ancestral habit, as shown on Plate V, Fig. 2; but this is enough to give it a new generic titlc, Cyrtoceras. As time went on the curving became more pronounced, as in the species shown on Plate V, Fig. 3, still of the cyrtoceran type. Finally the coil became complete, although the successive whorls did not touch the preceding ones; this stage of evolution (although in this case it is really involution) is called Gyroceras, a species of which is figured on Plate V, Fig. 4. Later still the successive coils began to touch and finally to embrace the preceding, and the culmination of the nautiloids is reached in Nautilus, as shown in Plate V, Fig. 5. These were formerly looked upon as generic stages, but Professor Hyatt * has shown that there were many straight forms that were not Orthoceras, many bent forms besides Cyrtoceras, many loosely-coiled forms that were not Gyroceras, and many close-coiled forms in addition to Nautilus. In other words, these corresponding stages of development were merely morphological equivalents of each other in different parallel lines of descent from the remote straight-shelled parent stock. Each nautilian form in its own development went through first an orthoceran stage, then a cyrtoceran,

* Genesis of the Arietidæ, and Phylogeny of an Acquired Characteristic. 
then a gyroceran, before taking on its own characters; each gyroceran form went through these in the same order up to its adult characters, but never reached the close-coiled nautilian stage; while the orthoceran forms remained in that stage of development all their lives. These genera were all progressive, and are numerous branches radiating from a common stock or radicle, the primitive straight nautiloid. Thus different nautilian forms may resemble each other closely, and yet be actually more closely related to the radicle form than they are to each other. Formerly such species were grouped together in one genus, and called "representative" species; now we know them to be merely morphological equivalents in different lines of descent.

When the close coiled stage was reached the nautilian shell had reached its limit, and could progress no further, and at once some of the stock began to retrograde. This is beautifully shown in the development of Lituites (Plate V, Fig. 6), which goes through the orthoceran, cyrtoceran, gyroceran, and nautilian stages, and as it becomes adolescent leaves the close coil and reverts to the orthoceran type. A number of other nautilian genera acted in this way, giving rise to a number of aberrant types. These reversionary nautiloids are confined to the Paleozoic, and did not in any case become radicles of later groups; they had run their course, exhausted the possibilities of development, and died out without descendants. But the old simple orthoceran type held out until the Trias, and the unspecialized nautilian shell endured until the present time, although now rapidly nearing extinction.

The animals that are capable of giving the best proof of evolution are the ammonoids. Somewhere back in the Silurian an Orthoceras by acceleration of development finally acquired a calcareous protoconch, or em- 



\section{EXPLANATION OF THE FIGURES.* \\ Plate II.}

All figures on this plate are fifteen times enlarged, except Fig. 9, which is once and a half its natural size.

Glyphioceras incisum Hyatт.

Figs. I and 2.-Adolescent stage, one and three fourths whorls, diameter of $1.29 \mathrm{~mm}$., last whorl is ananeanic (Prionoceras stage) and shows transition from paranepionic. I, front; 2 , side.

Figs. 3 and 4.-Adolescent stage, diameter of $1.37 \mathrm{~mm}$., one and seven eighths whorls, Prionoceras stage. 3 , from front; 4 , from side.

Figs. 5 and 6.-Adolescent stage, diameter of $1.64 \mathrm{~mm}$., two and one eighth whorls, Prionoceras stage. 5, from front ; 6 , from side.

Figs. 7 and 8.-End of adolescent stage, diameter of $2.25 \mathrm{~mm}$., two and three fourths whorls; transition from Prionoceras to Glyphioceras in the division of the ventral lobe, and beginning rounding of the whorl. 7 , side view ; 8 , front view.

Fig. 9.-Early adult stage, diameter of $15 \mathrm{~mm}$., once and a half enlarged.

* From The Development of Glyphioceras and the Phylogeny of the Glyphioceratidæ, by J. P. Smith. Proc. Calif. Acad. Sci., third series, vol. i, Geology, No. 3, Plate XIV. 
PLATE II.
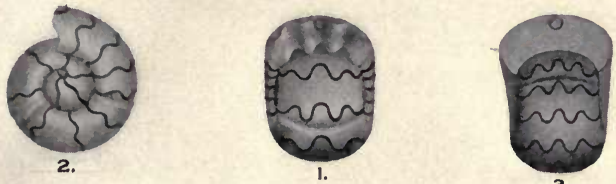

3.

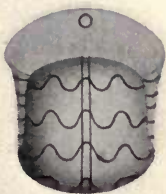

5.
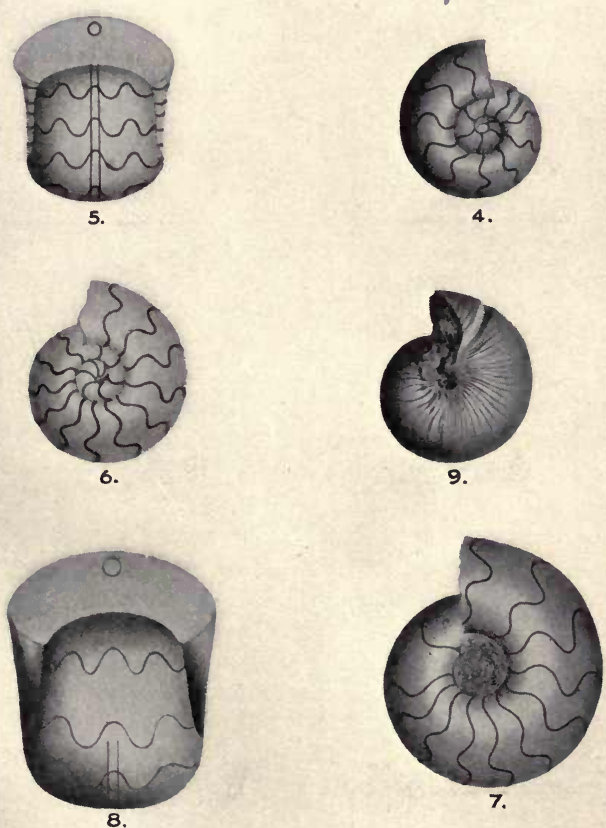

F.R.S. 

bryo shell, a marginal siphuncle, and a small siphonal lobe. This form, Bactrites, is transitional to the ammonoids, and may be considered as the radicle of that order; Plate V, Fig. 7, shows a magnified protoconch and early larval chambers of Bactrites. The true ammonoids developed out of Bactrites near the beginning of Devonian time; the first of these, the Nautilinida, differed from Bactrites in no respect except their coil, and Mimoceras (Plate V, Fig. 8) began its larval history as a straight Bactrites-like shell, then became curved like a Cyrtoceras, then loosely coiled like Gyroceras, and finally reached the primitive nautilian stage of involution. Anarcestes, another of the earliest Nautilinida, was successively cyrtoceran, gyroceran, and finally close-coiled nautilian. Thus in the ammonoids we have a single development series, corresponding to the many parallel series of the nautiloids; reversionary series did not come in until much later in the family history.

From the Nautilinida of the early Devonian the ammonoids branched out rapidly, continued increasing, diverging, became highly specialized and accelerated until their final extinction at the end of Cretaceous time. Each ammonite goes through a larval history that is long and varied in direct proportion to the length of time from its period back to the Lower Devonian. Thus in the Nautilinida we find very simple ontogeny, with no great changes from the larval up to the adult stages, except in the increasing involution of the later whorls. The higher Devonian and Carboniferous species go through several generic changes before they become adults, and Mesozoic forms have still longer larval and adolescent periods-that is, longer in the sense of having more stages.

From the work of L. von Buch, Quenstedt, and others of the older paleontologists, the increasing variety of 
forms from the goniatites of the Paleozoic, to the ammonites of the Mesozoic, was known long ago; these naturalists knew, too, that ammonites went through a goniatite stage in youth, without connecting this with evolution. By using their work we can get a comprehensive view of the development of ammonoids from the most primitive goniatites to the most highly developed ammonites, and thus construct a tentative family tree.

The simple primitive forms of the Lower Devonian branch out by the end of that age into two distinct stocks, the Prolecanitida and the Goniatitida, mostly low whorled, involute, with simple sutures and little ornamentation. Before the end of the Carboniferous some genera have already become ammonitic in the digitation of their sutures, as Popanoceras, Thalassoceras, Pronorites (Plate IV, Figs. 9 and 10), and some have taken on ammonitic ornamentation of the shell, while the sutures remain simple and entire, as Gastrioceras (Plate IV, Fig. II) and Paralegoceras (Plate IV, Figs. I 2 and I3). None of these forms, however, are very evolute, and the whorls are mostly rather low. These are all progressive in development, and probably nearly all became radicles of more highly specialized groups. No retrogressive, or reversionary, goniatites are known. In the Permian Pronorites and its descendants Sicanites and Medlicottia play an important part, the Arcestidae are already become important members of the fauna, the Tropitida are just beginning, while the Glyphioceratida are dying out. Some few genera still persist in the goniatitic stage, but most of them became ammonitic before the Trias was well on.

In the Trias the important groups are Arcestida, Pinacoceratida, Tropitida, Ceratitida, with numerous others less important as members of the Triassic fauna, but of great interest as ancestors of many of the chief families 
of the Jura and Cretaceous. In the Jura these ammonites reached their acme, branching out into very many families and subfamilies, increasing usually in complexity of sutures and variety of ornamentation. In the Cretaceous they gradually declined, dropping off one at a time until all were gone. The total number of $\mathrm{Am}$ monoidea now described reaches about five thousand, of which only a few hundred belong to the Paleozoic goniatites, the others belonging to the ammonites of the Carboniferous, Permian, and Mesozoic. Later than this no ammonoids are known.

Only simple radicles or stocks persist, but from time to time certain genera branch off from the main stock, become highly specialized, and often give rise to socalled abnormal* forms, phylogerontic or degenerate genera (retrogressive), which do not perpetuate their race. These leave their close coil, becoming straight, as Baculites (Plate V, Fig. 13); ascending spiral, as Turrilites (Plate V, Fig. 12); hook-shaped, as Macroscaphites (Plate V, Fig. I4); or open-coiled, gyroceran, as Crioceras (Plate V, Fig. II). These do not form a natural group, but are themselves even in some cases polyphyletic, as shown by their ontogeny; their larval stages, however, as shown even by the straight Baculites (Plate V, Fig. 13), all correspond to various normal closecoiled progressive genera, such as Lytoceras (Plate V, Fig. 10).

Of course there were phylogerontic genera that were not abnormal in shape; thus Clymenia branched off in the Upper Devonian into a variety of species, and disappeared as suddenly; Medlicottia reached its culmination in the Permian, barely managed to live on until the Trias, and disappeared without posterity, while the main

* J. F. Pompeckj. Ueber Ammonoideen mit Anormaler Wohnkammer. Stuttgart, r894. 
stock of unspecialized Prolecanitida endured as long as the race. The number of phylogerontic forms increases in the Mesozoic, showing a constantly increasing tendency to become abnormal, until before the end of the Cretaceous the entire race of ammonoids becomes phylogerontic, and dies out from sheer lack of plasticity to modify itself further with changing conditions.

Such a general view or family tree of the ammonoids may be seen in any of the text-books of paleontology, especially those of Steinmann,* and of $\mathrm{K}$. von Zittel, $\dagger$ where we get the best attempts to represent our present knowledge and ideas of the genetic relationships of ammonites. These genealogies are, however, purely tentative, based not on ontogeny but on comparison of series of adults. This would undoubtedly be the safest way if we had a perfect series of genera and species, but such a thing is unknown, and can never be obtained, on account of the incompleteness of the geologic record, and the mixing of faunas by migration in the past.

The researches of Hyatt, Branco, and Karpinsky have given us a surer way; from their work we have learned that the Ammonoidea preserve in each individual a complete record of their larval and early adolescent history, the embryonic protoconch and the young chambers being enveloped and protected by later stages of the shell. Also the record is a perfect one, for no resorption of stages of the shell has ever been observed in the chambered cephalopods. And so by breaking off the outer chambers the naturalist can in effect cause the shell to repeat its life history in inverse order, for each stage of growth represents some extinct ancestral genus. These genera appeared in the exact order of their minute imitations in the larval history of their descend-

* Elemente der Palæontologie, 1890.

† Grundzüge der Palæontologie, I895. 



\section{EXPLANATION OF THE FIGURES.* \\ Plate III.}

Schloenbachia nov. sp. aff. S. chicoensis Trask.

Fig. 1.-Cross-section, diameter $6.25 \mathrm{~mm}$., four whorls, seven and a half times enlarged, showing the embryonic protoconch in the centre, $P$.

Fig. 2.-Cross-section, adult, diameter $22.25 \mathrm{~mm}$., six whorls, one and three quarter times enlarged.

Fig. 3.-Protoconch and the first six septa of the attached coil, drawn as if unrolled, fifteen times enlarged.

Fig. 4.-Larval stage, diameter $.68 \mathrm{~mm}$., fifteen times enlarged, corresponds to the Carboniferous genus Glyphioceras.

Fig. 5.-Larval stage, diameter $.64 \mathrm{~mm}$., showing septa from the third to the tenth, fifteen times enlarged.

Fig. 6.-Septa in Glyphioceras stage, diameter .75 $\mathrm{mm}$., seven eighths whorls.

Fig. 7.-Larval stage, transitional from Glyphioceras to Gastrioceras, diameter $1.20 \mathrm{~mm}$., one and a half whorls, seven and a half times enlarged.

Fig. 8.-Septa in Gastrioceras stage, diameter $1.70 \mathrm{~mm}$., two coils.

Fig. 9.-End of larval stage, corresponds to the Carboniferous genus Paralegoceras, diameter $2.25 \mathrm{~mm}$., two and a quarter whorls, seven and a half times enlarged.

Fig. I0.-Septa in Paralegoceras stage, diameter $2.50 \mathrm{~mm}$., two and a half coils, end of larval stage.

Fig. I1.-Septa in Para-Styrites stage, fifteen times enlarged, diameter $3.80 \mathrm{~mm}$. (early adolescent).

Fig. 12.-Adolescent stage (Para-Styrites), four coils, diameter $5.60 \mathrm{~mm}$., seven and a half times enlarged.

Fig. 13.-Septa at diameter $6.40 \mathrm{~mm}$., fifteen times enlarged, three and three fourths whorls (middle adolescent).

* Figs. 1-4 from J. P. Smith, Journal Geol., vol. v, No. 5, Comp. Study of Palæontogeny and Phylogeny; all the other figures on this plate are original. Drawings by Frances R. Smith. 
PLATE III.
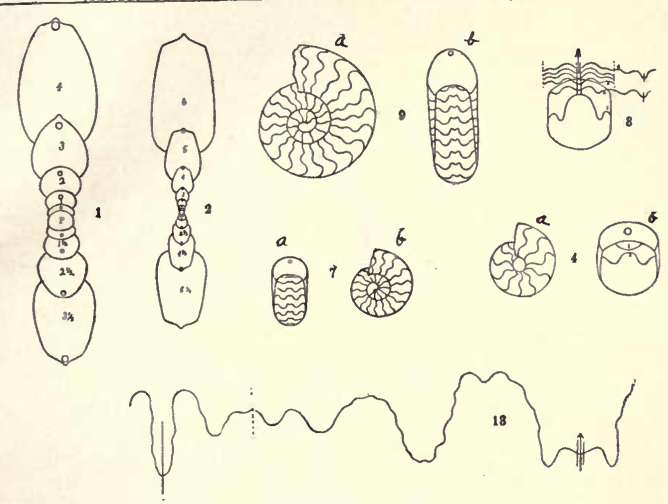

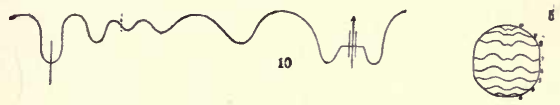

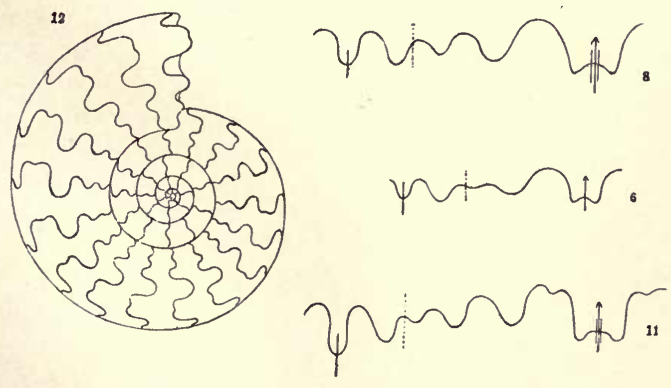


ants, and by a comparative study of larval stages with adult forms the naturalist finds the key to relationships, and is enabled to arrange genera in genetic series. They were all marine, never parasitic, always free, and so with them there is no obscuring of the record; also in the Mollusca generic and specific characters show in the shell better than in the soft parts; so the classification of fossil ammonites is just as good as that of living shellfish.

The importance of this will be appreciated if we consider other groups. The crustacean goes through successive stages and moults its shell after each change, thus making it difficult, especially in fossils, to find and study these various stages. The ammonite, after it has grown out of each stage of its shell, carries it around enveloped in the later chambers. So in a single specimen the record is complete, and may be read by skilful handling.

Although genera appeared in the order of corresponding larval stages, they did not disappear in the same order; and so their survival under favourable conditions is liable to make confusion in the record, if one depends wholly on the study of series of adults. Such forms, for instance, as Styrites, Tropiceltites, Miltites, and others, that are now known only in the Karnic zone of the Upper Trias, are undoubtedly such survivals, for they still have simple goniatitic sutures, very little ornamentation, and in general are more like Lower Triassic ammonites than members of the Tropites subbullatus fauna. The stray Tirolites foliaceus, which appears in the Alps and in California in this same fauna, is another survival of a Lower Triassic type, but fortunately we do know Tirolites in the horizon where it belongs. If this were not the case the naturalist would be very much puzzled at finding Trachyceras of the Karnic horizon 
going through a Tirolites stage in its early youth. Neither does the first discovery of a genus always correspond with its first appearance. For example, terebratuloid brachiopods are not known below the Devonian, but their existence in the Silurian is necessitated by the occurrence of a terebratuloid stage in the ontogeny of spire-bearing brachiopods (Ancylobranchia) of that age.

One great drawback to this work is that the ammonite faunas of the various ages have been classified by different specialists and on different principles, but all artificial. Thus the Triassic ammonites are divided into Leiostraca (smooth-shelled) and Trachyostraca (rough-shelled), a classification that can not be extended even to Jurassic groups. The Trachyostraca are further divided into Tropitida, with long body chamber, and Ceratitida, with short chamber. But neither of these groups is monophyletic, for it is quite probable, judging from their ontogeny, that members of both groups are derived from the Goniatitida, and others from the Prolecanitida. Further, the authorities agree in deriving the Tropitida from the Glyphioceratida, but the larval stages of some of the Tropitida show the undivided ventral lobe and an unmistakable resemblance to certain Prolecanitida; other so-called Tropitida show the divided ventral lobe at an early age, and a decided resemblance to the stock of Glyphioceratida.

In the same way most authorities agree that the Trachyostraca were all extinguished at the end of the Trias, and that all the Jurassic and Cretaceous ammonites, with the exception of Lytoceratida and Phylloceratida, were derived from the radicle Psiloceras, and this, too, in spite of the fact that many of the genera are rough shelled, and in their larval stages show marked likeness to trachyostracan genera. Any naturalist can convince himself of this by looking at the young stages 
年

3. 


\section{EXPLANATION OF THE FIGURES.*}

\section{Plate IV.}

Fig. 1.-Development of septa of Glyphioceras incisum Hyatt, from the protoconch to the eighth septum, $\frac{20}{1}$.

Fig. 2.-Adolescent septum of $G$. incisum, one and three fourth coils, diameter $1.29 \mathrm{~mm}$., twenty times enlarged (Prionoceras stage).

Fig. 3.-Septum of G. incisum, diameter $1.37 \mathrm{~mm}$. (Prionoceras).

Fig. 4.-Septum of G. incisum, diameter $1.64 \mathrm{~mm}$. (Prionoceras).

Fig. 5.-Septum of G. incisum, diameter $2.25 \mathrm{~mm}$., two and three quarter whorls, transition from Prionoceras to Glyphioceras.

Fig. 6.-Early adult septum of $G$. incisum, diameter $15 \mathrm{~mm}$.

Fig. 7.-Septa of Anarcestes subnautilinus Sandberger (after L. von Buch).

Fig. 8.-Development of the septa of Tornoceras retrorsum Buch (after Branco).

Fig. 9.-Development of the septa of Pronorites cyclolobus Phillips (after Karpinsky).

Fig. 10.-Adult septum of Pronorites cyclolobus, variety arkansiensis, J. P. Smith (after J. P. Smith, Proc. Amer. Phil. Soc., vol. xxv, No. 152, Plate XXIV, Fig. 4).

Fig. II.-Septum of Gastrioceras branneri J. P. Smith (loc. cit., Plate XXIII, Fig. 6).

Fig. 12.-Paralegoceras iowense Meek and Worthen (after J. P. Smith, loc. cit., Plate XIX, Fig. I).

Fig. 13.-Septa of $P$. iowense (after J. P. Smith, loc. cit., Plate XIX, Fig. $3^{b}$ ).

* The figures of G. incisum are from The Development of Glyphioceras and the Phylogeny of the Glyphioceratidx, by J. P. Smith. Proc. Calif. Acad. Sci., third series, vol. i, Geology, No. 3, Plate XV. The figures of Tornoceras are from Branco, Palæontographica, vol. xxvii, Plate V, Fig. 7. The septa of Pronorites cyclolobus are from Karpinsky, Ammoneen d. Artinsk-Stufe, Plate I, Fig. $4 g-l$. Drawings by Frances R. Smith. 

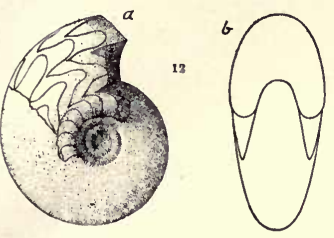

ron"twor

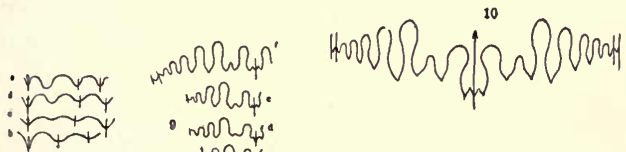

+4 s mane

Min

W

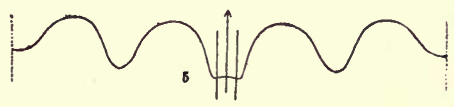

ณri

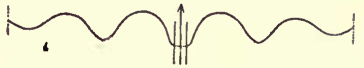

nn

1
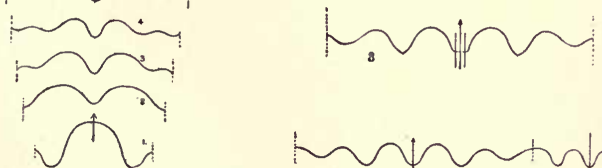

$\sim \sim \sim \psi h$ 

of Jurassic ammonites figured by Quenstedt.* Quite recently Prof. $W$. Waagen $\nmid$ has called attention to the likeness of certain Trachyostraca to Jurassic genera, and indicated the probability of genetic relationships. But Mojsisovics $\ddagger$ says that these similarities have nothing to do with relationship, but are purely " convergence phenomena," whatever that may mean. Resemblance of adults of Triassic and Jurassic forms might with some reason be ascribed to this mysterious agency, but surely no biologist would thus explain away the resemblance of larval and adolescent stages of Jurassic ammonites to adult Trachyostraca of the Trias. There was some excuse for such opinions as long as the fauna of the upper Trias was not well known, and there was apparently a great break in the series of ammonites. But after the appearance of the monographs of G. von Arthaber, Diener, Mojsisovics, and Waagen," on the Triassic faunas of the Alps, Himalayas, the Salt Range of India, and Siberia, there is no longer any such excuse. Ancestral types, long predicted by larval stages of Jurassic ammonites, may be seen in these works, as, for instance, Tropiceltites, which is exactly like the neanic stage of $\mathrm{Amal}$ theus; but the great variety is confusing, and correlation difficult, on account of unsatisfactory classification.

The only solution of the problem is to classify genetically the Paleozoic goniatites, and from them work upward into the Permian and Lower Triassic ammonites. These older groups have simpler larval stages, are not very greatly accelerated, and repeat clearly their ancestral history. When this is done the radicles will all

* Ammoniten des Schwabischen Jura.

† Pal. Indica, Salt Range Fossils, vol. ii, p. I22.

$\ddagger$ Das Gebirge um Hallstadt, Bd. ii, p. 265 .

\# For literature on Triassic faunas, see Jour. Geol., vol, iv, No. 4, J. P. Smith, Classification of Marine Trias. 
be known, and when we know the stock of the tree, the branches that came off in the higher Trias, Jura, and Cretaceous will offer no difficulties. The most systematic attempt to do this is Haug's paper, Les Ammonites du Permien et du Trias; * but his classification is based wholly on the character of the sutures, and neglects other characters, such as sculpture and shape of the whorls. Thus Haug places Eutomoceras with the prionidian family Trachyceratida, disregarding its ontogeny, which places it undoubtedly with the Tropitide. But no classification based entirely on one character can be truly genetic. $\dagger$

Study of the development of many species has shown that similar characteristics do not always mean close relationship; they may of ten be developed in different series coming from a common remote ancestor, and living under similar conditions. They are in no sense hereditary characters, but morphological equivalents acquired from the action of the same stimulus. The occurrence of orthoceran, cyrtoceran, gyroceran, nautilian, and reversionary stages in both nautiloids and ammonoids is a case in point. Compare the development and reversion of Lituites (Plate V, Fig. 6), of the nautiloid stock with that of Baculites (Plate V, Fig. I3) of the ammonoids, and the analogy becomes evident; compare also the reversionary Crioceras (Plate V, Fig. II) with the progressive Gyroceras (Plate V, Fig. 4). Hyatt, $f$ in his monographs on the ontogeny of ammonites,

* Bull. Soc. Géol. France, ii ser., vol. xxii, r894, No. 6.

† Since the above was written, Haug's Etudes sur les Goniatites, Mém. Soc. Géol. France, 1898, has appeared, but could not be used in this paper.

$\ddagger$ Bull. Mus. Comp. Zool., vol. iii, No. 5,1872 ; and Smithsonian Contrib. to Knowledge, Genesis of the Arietidae, and other papers. 
has shown us the way; Branco, by his studies of the larval stages of ammonoids, has accumulated a great mass of accurate data that can be used with confidence, even by the student that rejects his theories as to classification. And Karpinsky, by using the methods and principles discovered by these naturalists, has worked out the genealogy of one of the chief stocks of the earlier ammonites. This way lies the truth, and not in groundless speculations such as many students of cephalopods are prone to indulge in.

In order to succeed, one must select material with great care, preferably limestone that is soft but not so Method of working. weathered as to crumble; nor so brittle as to shatter. One's finger nail and some steel dental chisels are all the tools needed for breaking off the outer whorls of young ammonites. A microscope with thirty diameters magnifying power is the most satisfactory, although higher powers are occasionally needed. For studying surface markings a strong pocket lens is usually sufficient; the specimen should then be placed dry on white cardboard. For observing the sutures, or shape of the whorls, the specimen should be placed on cardboard in a drop of water, spread out so as not to distort the object. The water, being slightly viscous, will also hold the small object in any position. For taking measurements a micrometer eyepiece is needed, especially in drawing, for the camera lucida is not very satisfactory for drawing opaque objects. Sections can easily be cut by grinding with emery powder on a glass plate.

The accompanying illustrations will give an idea of how the facts are ascertained. A number of well-preserved adults of a species are selected, and the outer coils are pulled off piece at a time under water, until a complete series is obtained, representing every change 
in growth. All the pieces of whorls are preserved, but often it is possible to have a complete series in one specimen. The individuals representing stages of growth are kept separate, in small glass tubes attached to cards for labels, on which are noted the measurements of the specimen, stage of growth, and such other facts as are wanted for ready reference.

The points to be noted in studying the development of chambered cephalopods are : character of the protoconch or embryo shell; position of the siphuncle, whether internal, median, or external; character and direction of the siphonal collars, as on Plate V, Fig. 9, where Tropites phoebus has the young siphonal collars pointing backward, and the old ones pointing forward, also change of the siphuncle from the internal to the external margin of the whorl; increasing lobation of the septa with advancing growth; changes in the spiral of the coil; increasing involution, height of whorls, and ornamentation of the outside shell. By observing carefully these changes in character, the successive stages may be sharply distinguished from each other from the beginning of the larval period to the old age of the shell.

No one species in its life history gives the entire history of the race; the earlier forms do not get far along in development, while the later ones hasten through the earlier generic stages so rapidly that a Jurassic or Cretaceous species of ten begins life where a Paleozoic form in the same line of descent left off. We are thus often forced to piece out the development history with successive species, using both the development of the individual and the successive development seen in the rocks. The writer has recently worked out the development of Glyphioceras of the Carboniferous, and Schloenbachio of the Cretaceous, in the same line of 



\section{EXPLANATION OF THE FIGURES.}

\section{Plate V.*}

Fig. 1.-Orthoceras timidum Barrande (after Zittel, Pal., ii, Fig. 518$)$.

Fig. 2.-Cyrtoceras corbulatum Barrande (after Zittel, Pal., ii, Fig. 531).

Fig. 3.-Cyrtoceras murchisoni Barrande (after Zittel, Fig. 529).

Fig. 4.-Gyroceras alatum Barrande (after Zittel, Fig. 535).

Fig. 5.-Nautilus planotergatus McCoy (after Zittel, Fig. 539).

Fig. 6.-Lituites lituus Montf. (after Zittel, Fig. 536).

Fig. 7.-Bactrites protoconch (after Branco, Palæontographica, vol. xxvii, 1880).

Fig. 8.-Mimoceras compressum Sandberger (after Branco, Pal., vol. xxvii, Plate VIII).

Fig. 9.-Tropites phabus Dittmar (after Branco).

Fig. 10.-Lytoceras liebigi Oppel (after Zittel, Pal., ii, Fig. 632).

Fig. II.-Crioceras emerici Léveillé (after T. Wright, Pal. Soc., vol. xxxiv, I880, Lias Ammonites, Fig. 86).

Fig. I2.-Turrilites catenatus d'Orb. (after Zittel, Pal., ii, Fig. 640).

Fig. 13.-Baculites compressus Say (after A. P. Brown, Proc. Acad. Nat. Sci., Philadelphia, 1892, Plate IX, Fig. I).

Fig. 14.-Macroscaphites ivanii d'Orb. (after Zittel, Pal., ii, Fig. 635).

* Drawings by Frances R. Smith. 
PLATE V.

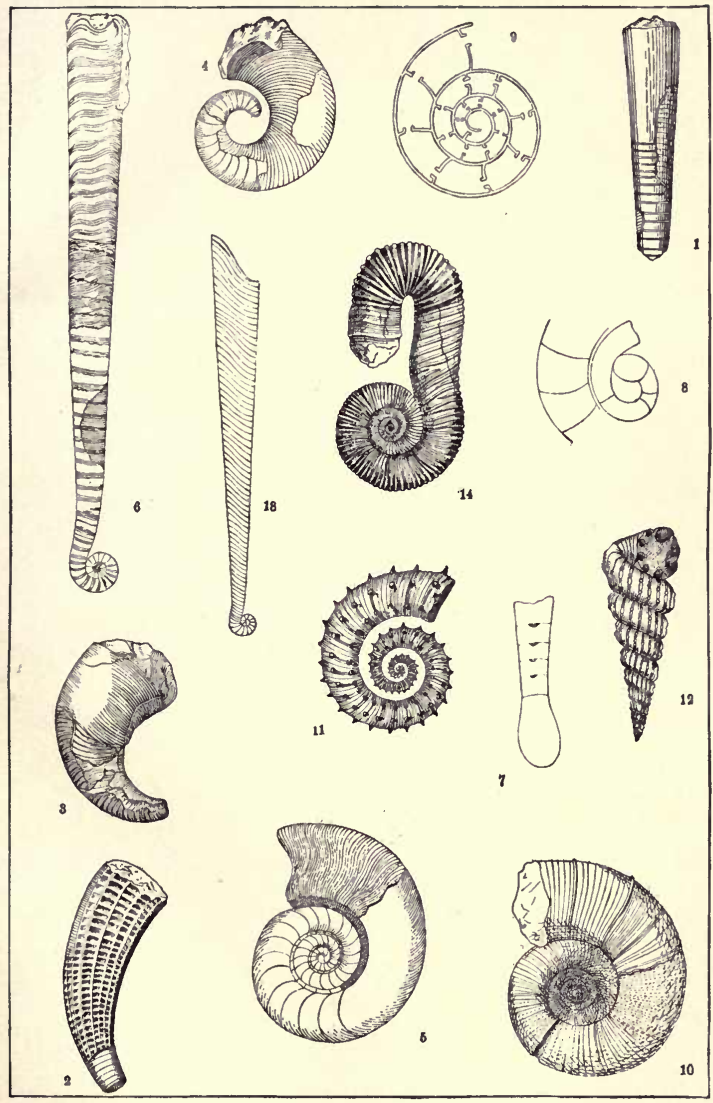



descent; Glyphioceras goes through distinctly the stages from Anarcestes of the Devonian, through Tornoceras and Prionoceras, finally stopping in the Glyphioceras stage. Schloenbachia hastens through the Anarcestes, Tornoceras, and Prionoceras so that they are hardly recognisable, and gets to be a Glyphioceras even in its middle larval stage, goes through two more goniatite stages, and several ammonite stages before it becomes a Schloenbachia.

\section{DEVELOPMENT OF GLYPHIOCERAS.}

Glyphioceras in its development does not show the Bactrites (Plate V, Fig. 7) and Mimoceras (Plate V, Fig. 8) stages, so these must be studied in lower forms; but from the Anarcestes stage up they are sharply defined. It begins life as a protoconch or embryonic shell while undoubtedly still in the egg; this (shown on Plate I, Figs. I-5) corresponds to the primitive cephalopod. At the beginning of its larval stage the animal left the protoconch, built up the first body chamber, and cut off the embryonic part of the shell by the first septum (Plate I, Figs. 6 and ro, Plate IV, Fig. r, r) ; at this stage the shell is analogous to the primitive nautiloid, and it is called in Hyatt's nomenclature ananepionic. With the second chamber the young shell becomes an ammonoid, and corresponds to the genus Anarcestes of the Lower Devonian; this is shown on Plate I, Fig. 6, and on the second and third septum of Fig. 9, also Plate IV, Fig. I, second and third sutures. On Plate IV, Fig. 7 shows for comparison the septa of Anarcestes subnautilinus Sandberger. At the fourth suture the shell is transitional to Tornoceras of the Middle Devonian. Plate I, Fig. 9, shows the beginning of the Tornoceras stage, which lasts through the sixth chamber, as shown on Fig. 12, and on Plate IV, Fig. 1, at the fourth and fifth septa. For comparison the development of the septa of 
Tornoceras retrorsum Buch is figured on Plate IV, Fig. 8. At the seventh chamber, three fourths of a whorl, and diameter of about 0.85 millimetre, the shell changes its form rather suddenly, the umbilicus widens, the body chamber narrows, and the number of lobes and saddles increases; this stage corresponds to the Upper Devonian genus Prionoceras, as shown on Plate I, Figs. II and I2; and more advanced on Plate II, Figs. 2-6, the resemblance to that genus being perfect in everything except size, and any naturalist would have described these stages as Prionoceras if they had not been taken out of the inner coils of Glyphioceras. The septa of this stage are shown on Plate IV, Fig. I, eighth septum, and Figs. 2, 3 , and 4 ; Fig. 5 shows the transition to Glyphioceras, and the corresponding shell is shown on Plate II, Figs. 7 and 8. The adult is shown on Plate II, Fig. 9, and Plate IV, Fig. 6.

\section{DEVELOPMENT OF SCHLOENBACHIA.}

Schloenbachia begins its development almost where Glyphioceras leaves off, or rather it hastens through the stages before the Glyphioceras stage so rapidly that they are almost unrecognisable. On Plate III, Fig. 3 shows the embryonic protoconch, and the first six septa drawn as if unrolled, in which short space it hastens through the stages corresponding to Anarcestes, Tornoceras, Prionoceras, and becomes a Glyphioceras. Fig. 4 shows the shell in that stage, and Fig. 6 shows the corresponding septa. Fig. 7 shows the transition to the Gastrioceras stage, the septa of which are seen in Fig. 8. The next stage corresponds to the Carboniferous genus Paralegoceras, Figs. 9 and ro, and with this the goniatitic larval period ends. The first adolescent (ammonitic) character that appears is a keel, at the diameter of 2.7 millimetres, and shortly after this the first lateral saddle becomes 
divided by a secondary lobe (Plate III, Fig. II), and the whorl becomes higher and the spiral wider (Fig. 12). Shortly after this the lobes and saddles all become slightly digitate (Fig. 13), and the family relationship of the young shell are unmistakable.

Fig. I shows a cross-section of an adolescent shell, four whorls, in which the broad, low helmet-shaped inner whorls, the widening of the umbilicus, increase in height of the later whorls, development of the keel, and flattening of the sides are shown, seven and a half times enlarged.

Fig. 2 shows an adult cross-section, six whorls, one and three quarter times enlarged, showing the angular shoulders and considerable involution of the adult shell.

Since Schloenbachia appears near the time of final extinction of the ammonites, and is still normal in development, it gives in its own development an admirable epitome of the history of the race. And by combining this with the ontogeny of its ancestor, Glyphioceras, we are able to trace the genealogy with certainty back to the first ammonoids that appeared in geologic history.

By following this method the complete ontogeny of any species of ammonite may be worked out, and in order to learn the phylogeny of any form it is only necessary to combine this with comparative study of antecedent genera and species. When this is done for all the Ammonoidea, their genealogy will be more perfectly known than any other family tree possibly can be. If evolution needs any demonstration to raise it from a working hypothesis to a fixed principle of biology we have it in the history of the fossil cephalopods. 


\section{$\mathrm{X}$.}

THE EVOLUTION OF THE MIND.

"Three roots bear up dominion, Knowledge, Will, The third, Obedience, the great tap-root of all."

LOWELL.

THE mind, in the sense in which I shall use the word here, is the collective function of the sensorium or brain Mind the sum total of psychic changes. of man and animals. It is the sum total of all psychic changes, actions, and reactions. Under the head of psychic functions are included all operations of the nervous system, as well as operations of like nature which take place in creatures without specialized nerve fibres or nerve cells.

As thus defined, mental operations are not necessarily or exclusively conscious. With the lower animals

Mind not nearly all of them are automatic and unconściousness. conscious. Even with man, most of them must be so. But between the automatic and the conscious actions no sharp line of division exists. Consciousness is not an entity but a condition. It stands related to mind much as flame is related to fire. All functions of the nervous system are alike in essential nature, and from the present point of view may be considered together.

It is a recognised law in biology that "function precedes structure." To define this law more exactly we 
should say that function precedes the differentiation of the organ on which it depends. There is a certain work to be done and a certain body of cells are set apart

Function

precedes

structure. sooner or later to do it. Just as ploughing was done in some fashion before the invention of the plough, so in some manner respiration was accomplished before the development of gills and lungs. Something of mental action came before there was an organized brain. This law involves nothing mysterious or incomprehensible. It does not, so far as we know, imply the preexistence of mind or the carrying out of any predetermined purpose in development. All this may be or may not be, but the phenomena in question throw no light on it. The fact seems to be that when the bodily processes make certain demands on an organism, these demands will be met in some fashion. Through natural selection some better structure will come into competition. The cells and tissues on which the function depends will be specialized as an organ. In creatures of different ancestry the same function may be discharged by widely different organs. Conversely, what is ancestrally the same organ may in different groups of animals serve functions widely different.

In the animals of one cell, or protozoa, breathing and digestion are each performed by the whole body. In the division of labour or specialization which arises in the higher or many-celled animals certain alliances of cells or tissues are set apart for respiration alone, and certain others for digestion, while other functions of animal life are relegated to still other cell alliances. Each organ in turn is released from all functions except its own.

Irritability, or the response to external stimulus, is an attribute of all living organisms. In the method 
and degree of response variations occur. Those variations favourable to the division of labour and the adaptation of the animal to its surroundings Irritability the basis of mind. are seized and fixed by natural selection. In this way, on the basis of a diffused function, an organ is built up and the organ itself is specialized and perfected.

The mind and consciousness of man is an outgrowth from the irritability of the lower animals, developed through series of "successive differen-

The brain adequate for the mind. tiations and integrations." All the higher animals are colonies of co-operating and co-ordinated cells. In such colonies of units the functions of sensation, thought, and motion are relegated to series of the most sensitive and most highly organized cells. This alliance of cells is adequate for the work it has to perform. The brain is always adequate for the mind, for the one is the organ, the other the function, and the development of the two must go on together.

The intellect of man can not be regarded as the crowning marvel of the "great riddles of life." A marThe marvel of life. vel is no greater for its bigness. Life is one continuous marvel, without break or end. The human mind is one of life's manifestations. The marvel appears in great or small psychic powers alike, for the great powers of the manycelled brain are produced by the co-operation and specialization of the small powers of the single cell. Nature knows neither great nor small. "God works finer with his hands than man can see with his eyes." The single cell is far from simple. The egg or germ cell carries within itself the whole machinery, as well as the whole mystery, of heredity. The simplest organism we know is far more complex than the constitution of the 
United States. Its adjustments, checks, and balances are more perfect. It should in its changing relations be compared rather with the great unwritten constitution of civilized society. The laws of society spring from the laws governing the development of the single cell. If we knew the latter "all in all," as Tennyson says of the flower, "we should know what God is and man is."

If we could follow any life problem to its uttermost detail, we should have the clew to all life.

Among the protozoa, as already stated, all activities are centred in the single cell which forms the animal Activities of protozoa. unit. Each cell is sufficient unto itself. It is independent and free, but it is at the same time unspecialized and ineffective. Its career offers no wide play for volition, for a single life unit can not control the elements which surround it. It is the sport of the wind and the wave. But the recognition of self and non-self, which in one form or another is the attribute of all life, is not wanting among the protozoa. Some of them develop this sense to a large degree. It is said that among the rhizopods are those whose appendages or pseudopodia are at once cast off if they come in contact with the appendages of another of the same species. This recognition of self and non-self is not intellect, but it is homologous with the impulses on which in the higher types personality depends.

All sensation has reference to action. If a creature is not to act it can not feel. Wherever motion exists there is some sensitiveness to external Sensation related to action. conditions, and this is of the nature of mind. In a compound organism the nature and position of the sensorium or mind centre depends on what it has to do, or rather on what were the 
duties the same structure had to perform in the life of the creature's ancestors.

A plant may be defined as a sessile animal. It is an organic colony of cells, with the power of motion in

Mind of the plant. parts but not that of locomotion. The plant draws its nourishment from inorganic nature-from air and water. Its life is not conditioned on a search for food, nor on the movement of the body as a whole.

The plant searches for food by a movement of the feeding parts alone. In the process of growth, as Darwin has shown, the tips of the branches and roots are in constant motion. This movement is in a spiral squirm. The movement of the tendrils of the growing vine is only an exaggeration of the same action. The course of the squirming rootlet may be deflected from a regular spiral by the presence of water. The moving branchlets will turn toward the sun. The region of sensation in the plant and the point of growth are identical because this is the only part that needs to move. The tender tip is the plant's brain. If locomotion were in question the plant would need to be differently constructed. It would demand the mechanism of the animal. The nerve, brain, and muscle of the plant are all represented by the tender growing cells of the moving tips. The plant is touched by moisture or sunlight. It "thinks" of them, and in so doing the cells that are touched and "think" are turned toward the source of the stimulus. The function of the brain, therefore, in some sense exists in the tree, but there is no need in the tree for a specialized sensorium.

The many-celled animals from the lowest to the highest bear in their organization some relation to locomotion. The animal feeds on living creatures, and these it must pursue if it is to thrive. It is not the sensitive 
nerve tips which are to move; it is the whole creature. By the division of labour the whole body of the com-

Locomotion

demands

sensation. pound organism can not be given over to sensation. Hence the development of sense organs different in character: one stimulated by waves of light, another by waves of sound; one sensitive to odour, another to taste; still others to contact, temperature, muscular strain, and pain. These sense organs must through their nerve fibres report to a sensorium which is distinct from each of them. And in the process of specialization the sensorium itself is subdivided into higher and lower nerve centres; centres of conscious thought and automatic transfer of impulse into motion. This transfer indicates the real nature of all forms of nerve action. All are processes of transfer of sensation into movement. The sensorium or brain has no knowledge except such as comes to it from the sense organs through the ingoing or sensory nerves. It has no power to act save by its control of the muscles through the outgoing or motor nerves. The mind has no teacher save the senses; no servants save the muscles.

The reflex action then is the type of all mental operations. The brain is hidden in darkness, protected from Reflex action. sensation as also from injury by a bony box or a padding of flesh. It has no ideas of its own. It can receive no information directly. But the sense organs flood it with impressions of the external world, and to these impressions the brain chooses corresponding acts. From the body itself, by similar means, are transmitted impressions which become impulses to action. Such tendencies in all animals and men are transmitted from generation to generation as a part of the legacy of heredity. They are in their nature rather methods of movement than impulses 
to act. Motion goes along lines of least resistance, and such lines are part of the stock of heredity.

Many of the impressions from environment are received by the lower nerve centres alone, the sympathetic system or the spinal cord. Here they are converted at once into motion without rising into the region of consciousness. Other sensations rise to the brain itself and are made the basis of voluntary and conscious action. And between the purely automatic actions and those distinctly conscious and voluntary there may be found every possible intermediate grade.

Moreover, a conscious action often repeated becomes in some degree reflex and automatic. By repeated action nerve connections are formed, The higher heredity. which have been compared to the automatic switches of the electric-light plant. By these connections an action once become familiar requires no further conscious attention. This fact is known to us as the formation of habit. That which we do to-day voluntarily and even laboriously, the force of habit will cause us to repeat to-morrow easily, involuntarily, and whether we will or not. By the repetition of conscious actions the character is formed. This formation of personal character by action I have elsewhere called "the higher heredity," as distinguished from the true heredity which finds its bounds in the content of the germinal cell. By means of habits each creature builds up in some fashion its own life. In such way and to some degree each is "the architect of his own fortunes." In such manner "the vanished yesterdays" are the tyrants of to-morrow.

Besides the actual sensations, the so-called realities, the brain retains also the sensations which have been received, and which are not wholly lost. Memory-pictures crowd the mind, mingling with pictures brought in afresh 
by the senses. The force of suggestion causes the mental states or conditions of one person to repeat them-

Realities and illusions. selves in others. Abnormal conditions of the brain itself furnish another series of feelings with which the brain must deal. Moreover, the brain is charged with impulses to action passed on from generation to generation, surviving because they are useful. With all these arises the necessity for choice as a function of the mind. The mind must neglect or suppress all sensations which it can not weave into action. The dog sees nothing that does not belong to its little world. The man in search of mushrooms "tramples down oak trees in his walks." To select the sensations that concern us Selection of sensations. is the basis of the power of attention. The suppression of undesired action is a function of the will. To find data for choice among the possible motor responses is a function of the intellect. Intellectual persistency is the essence of individual character.

As the conditions of life become more complex, it becomes necessary for action to become more carefully selected. Wisdom is the parent of virtue. Knowing what should be done logically precedes doing it. Good impulses and good intentions do not make actions safe. In the long run, action is tested not by its motives, but by its results.

The child when he comes into the world has everything to learn. His nervous system is charged with tendencies to reaction and impulses to motion, which have their survivals from ancestral experience. Exact knowledge, by which his own actions can be made exact, must come through his own experience. The experience of others must be expressed in terms of his own before it becomes wisdom. Wisdom, as I have elsewhere said, 
is knowing what one ought to do next. Virtue is doing it. Doing right becomes habit if it is pursued long enough. It becomes a "second nature," or a higher heredity. The formation of a higher heredity of wisdom and virtue, of knowing right and doing right, is the basis of character-building.

The moral character is based on knowing the best, choosing the best, and doing the best. It can not be

Robust men make history. built up on imitation. By imitation, suggestion, and conventionality the masses are formed and controlled. To build up a man is a nobler process, demanding materials and methods of a higher order. The growth of man is the assertion of individuality. History is the record of the acts of robust men.

The first relation of the child to external things is expressed in this: What' can I do with it? What is its The relation of the child to the environment. relation to me? The sensation goes over into thought, the thought into action. Thus the impression of the object is built into the little universe of his mind. The object and the action it implies are closely associated. As more objects are apprehended, more complex relations arise, but the primal condition remains, What can I do with it? Sensation, thought, action, this is the natural sequence of each completed mental process. As volition passes over into action, so does science into art, knowledge into power, wisdom into virtue.

It is thus evident that, with an animal as with an army, locomotion demands direction. The sensorium is The sensorium. built up as a director of motion. Natural selection causes the survival of those whose sensorium is adequate for the safe control of movement. The animal which conducts its life processes in insecurity perishes. The existence of an or- 
ganism is the test of its adequacy. The continued existence of a series of organisms is the ultimate proof of the truth of the senses.

With the lower animals we have automatic obedience to the demand of external conditions. The greater the

Nature of instinct. stress of the environment the more perfect the automatism, for impulses to safe action must always be adequate for the duty which in the ancestral past they have had to perform. To automatic mind processes inherited from generation to generation the name instinct has been given. Whether instinct is in any degree inherited habit or whether it is the product simply of natural selection acting upon the varying methods of automatic response, destroying those whose responses are inadequate, need not concern us now.

The homing instinct of the fur seal, concluding its long swim of three thousand miles by a return on a little Instinct of the fur seal. island hidden in the arctic fogs, to the very spot from which it was driven by the ice six months before, excites our astonishment. But this power is not an illustration of animal intelligence. The homing instinct with the fur seal is a simple necessity of life. Without it the individual would be lost to its species. Only those which have the instinct in perfection can return. Only those who return can leave descendants. As to the others the rough sea tells no tales. We know that not all of the fur seals who set forth come back. To those who do return the homing instinct has proved adequate. And this it must always be so long as the race exists, for general inadequacy would mean extinction of the species.

The intellect, as distinguished from lower mental operations, is the choice among responses to external 
conditions. Complex conditions permit a variety of responses. Varying conditions demand a change of reNature of the intellect. sponse. This demand is met by the intellect. The intellect rises with a complex or changing environment. The greater the stress on a race of thinking creatures, the more active and effective their thoughts. The growth of man has been a succession of triumphs over hard conditions. Effect of adversity on the intellect.

The races which have been successful have arisen from adversity. Prosperity has been the conquest of hard times. Human progress in general has come through the falling away of the ineffective. The foolkiller has been its most active agent. "The goodness and the severity of God" are in science one and the same thing, as they were in the thought of the prophet. Its essence is the survival of those who can live and act effectively and happily in the conditions which surround human and animal life. The power of safe and accurate response to external conditions is the essential feature of sanity. The inability to adapt action to need is a character of insanity. Insanity, except as protected by human altruism, means death.

The difference between intellect and instinct in lower animals may be illustrated by the conduct of Intellect of the monkey people. certain monkeys brought into relation with new experiences. At one time I had two adult monkeys, "Bob" and "Jocko," belonging to the genus Macacus. Neither of these possessed the egg-eating instinct. At the same time I had a baby monkey, "Mono," of the genus Cercopithecus. Mono had never seen an egg, but his inherited impulses bore a direct relation to feeding on eggs, just as the heredity of Macacus taught the others how to crack nuts or to peel fruit. 
To each of these monkeys I gave an egg, the first that any of them had ever seen.

The baby monkey, Mono, being of an egg-eating race, devoured his egg by the operation of instinct or inherited habit. On being given the egg for the first time, he cracked it against his upper teeth, making a hole in it, and sucked out all the substance. Then holding the egg-shell up to the light and seeing that there was no longer anything in it, he threw it away. All this he did mechanically, automatically, and it was just as well done with the first egg he ever saw as with any other he ate. All eggs since offered him he has treated in the same way.

The monkey Bob took the egg for some kind of nut. He broke it against his upper teeth and tried to pull off the shell, when the inside ran out and fell on the ground. He looked at it for a moment in bewilderment, took both hands and scooped up the yolk and the sand with which it was mixed and swallowed the whole. Then he stuffed the shell itself into his mouth. This act was not instinctive. It was the work of pure reason. Evidently his race was not familiar with the use of eggs and had acquired no instincts regarding them. $\mathrm{He}$ would do it better next time. Reason is an inefficient agent at first, a weak tool ; but when it is trained it becomes an agent more valuable and more powerful than any instinct.

The monkey. Jocko tried to eat the egg offered him in much the same way that Bob did, but, not liking the taste, he threw it away.

The low intelligence of the lower animals-as the fishes-may be at times worse than none at all. If mental development were a real advantage to fishes it would arise through natural selection. The fishes taken in a large pound net, as I have observed them in Lake 
Michigan, can not escape from it because they have not intelligence enough to find the opening through which they have entered. If, however, a loon enters the net the fishes become frightened and "lose their heads." In this case they will sooner or later all escape, for they cease to hunt about ineffectively for an opening, and flee automatically in straight lines, and these straight lines will in time bring them to the open door of the net.

Wild animals learn to avoid poisonous plants by instinct. Those who have not an inherited dislike for these plants perish. When the animals are brought into contact with vegetation unknown to their ancestors this instinct fails them. Hence arises in California the danger from "loco weeds," as certain species of wild vetches are called. These plants produce temporary or permanent insanity or paralysis of nerve centres. The native ponies avoid them, but imported animals do not, and often fall victims to their nerve-poisoning influence. In the long run, only those survive who dislike the "loco-weed" and avoid it instinctively.

The confusion of highly perfected instinct with intellect is very common in popular discussions. Instinct

Intellect the choice of responses.

grows weak and less accurate in its automatic obedience as the intellect becomes available in its place. Both intellect and instinct are outgrowths from the simple reflex response to external conditions. But instinct insures a single definite response to the corresponding stimulus. The intellect has a choice of responses. In its lower stages it is vacillating and ineffective; but as its development goes on it becomes alert and adequate to the varied conditions of life. It grows with the need for improvement. It will therefore become impossible for the complexity of life to outgrow the adequacy of man to adapt himself to its conditions. 
Many animals currently believed to be of high intelligence are not so. The fur seal just mentioned, for Intellect of the example, finds its way back from the fur seal. long swim of two or three thousand miles through a foggy and stormy sea, and is never too late or too early in arrival. The female fur seal goes two hundred miles to her feeding grounds in summer, leaving the pup on the shore. After a week or two she returns to find him within a few rods of the rocks where she had left him. Both mother and young know each other by call and by odour, and neither are ever mistaken, though ten thousand other pups and other mothers occupy the same rookery. But this is not intelligence. It is simply instinct, because it has no element of choice in it. Whatever its ancestors were forced to do the fur seal does to perfection. Its instincts are perfect as clockwork, and the necessities of migration must keep them so. But if brought into new conditions it is dazed and stupid. It can not choose when different lines of action are presented.

The Bering Sea Commission once made an experiment on the possibility of separating the young male fur seals, or "killables," from the old ones in the same band. The method was to drive them through a wooden chute or runway with two valve-like doors at the end. These animals can be driven like sheep, but to sort them in the way proposed proved impossible. The most experienced males would beat their noses against a closed door, if they had seen a seal before them pass through it. That this door had been shut and another opened beside it passed their comprehension. They could not choose the new direction. In like manner a male fur seal will watch the killing and skinning of his mates with perfect composure. He will sniff at their blood 
with languid curiosity. So long as it is not his own it does not matter. That it may be his own in a minute or two he can not foresee.

The study of the development of mind in animals and men gives no support to the mediæval idea that the mind exists as an entity apart from the organ

The clavier theory of mind. through which it operates. This "clavier theory" of the mind, that the ego resides in the brain, playing upon the cells as a musician upon the chords of a piano, finds no warrant in fact. So far as the evidence goes, we know of no ego* except that which arises from the co-ordina-

* That what we really know of human personality tells the whole story of it, no one should maintain. It is well, however, not to ascribe to it entities and qualities of which we know nothing. Huxley well says: "There can be little doubt that the further science advances, the more extensively and consistently will all the phenomena be represented by materialistic formulæ and symbols. But the man of science who, forgetting the limits of philosophical inquiry, slides from these formulæ and symbols into what is commonly understood by materialism, seems to me to place himself on a level with the mathematician who should mistake the x's and y's with which he works his problems for real entities; and with this further disadvantage as compared with the mathematician, that the blunders of the latter are of no practical consequence, while the errors of systematic materialism may paralyze the energies and destroy the beauty of life.

"We live," continues Huxley, " in a world which is full of misery and ignorance, and the plain duty of each and all of us is to try to make the little corner he can influence somewhat less miserable and somewhat less ignorant than it was before he entered it. To do this effectually it is necessary to be fully possessed of two beliefs-the first, that the order of nature is ascertainable by our faculties to an extent which is practically unlimited; the second, that our volition counts for something as a condition of the course of events.

"Each of these beliefs can be verified experimentally as often as we like to try. Each, therefore, stands upon the strongest 
tion of the nerve cells. All consciousness is "colonial consciousness," the product of co-operation. It stands Colonial consciousness. related to the action of individual cells much as the content of a poem with the words or letters composing it. Its existence is a phenomenon of co-operation. The $I$ in man is the expression of the co-working of the processes and impulses of the brain. The brain is made of individual cells, just as England is made of individual men. To say that England wills a certain deed, or owns a certain territory, or thinks a certain thought, is no more a figure of speech than to say that "I will," "I own," or "I think." The "England " is the expression of union of the individual wills and thoughts and ownerships of Englishmen. Similarly, my "Ego" is the expression of the aggregate force resulting from co-ordination of the elements that make up my body.

The old dictum of the philosopher, "I think, therefore I am," is not literally and wholly true. "We think, "Cogito, ergo sum." therefore we are," we the aggregation of brain cells, would be quite as truthful. But we brain cells do not think individually; only collectively or colonially. So no single sentence can express the whole truth, nor can a trustworthy philosophy grow out of any single psychological axiom.

The development of the character is the formation of the ego. It is in itself the co-ordination of the elements of heredity, the bringing into union of warring

foundation upon which any belief can rest, and forms one of our highest truths. If we find that the ascertainment of the order of nature is facilitated by using one terminology or one set of symbols rather than another, it is our clear duty to use the former; and no harm can accrue so long as we bear in mind that we are dealing merely with terms and symbols." 
tendencies and irrelevant impulses left us by our ancestors. The child is a mixture of imperfectly related Development of the ego. impulses and powers. It is a mosaic of ancestral heredity. Its growth into personality is the process of bringing these elements into relation to each other.

In his study of the phenomena of "conversion," Edwin Diller Starbuck gives this view of the physioThe building of the self. logical phenomena associated with the development of personality, the building up of a self by a process which "is primarily unselfing." "It is pretty well known," Dr. Starbuck says, "that the quality of mind is much dependent upon the fineness of nervous structure. The child has about as many nerve cells as the adult. They differ from those of the adult in form. Those of the child are mostly round, whereas those of the adult have often very many branches with which they connect with the other cells. Nervous growth seems to consist largely in the formation of new nervous connections. The rapid growth at puberty probably means that at that time there is a great increase in nervous branching. The increased ramification of nervous tissue probably determines the ability for seeing in general terms, for intellectual grasp, and for spiritual insight. The rapid formation of new nerve connections in early adolescence may be the cause of the physiological unrest and mental distress that intensifies into what we have called the sense of incompleteness which precedes conversion. The mind becomes a ferment of half-formed ideas, as the brain is a mesh of poorly organized parts. This creates uncertainty, unhappiness, dejection, and the like, because there is not the power of free mental activity. The person is restless to be born into a larger world that is dimly felt. Finally, through wholesome sugges. 
tions or normal development, order comes and then ew world dawns. Often some emotional stress or shock strikes harmony into the struggling imperfection and truth comes like a flash."

The evil effect of the excess of sense impressions and of thought dissociated from will and action has been Sensation withnoted many times and in many ways. out action.

When men have made themselves wise with the lore of others, the learning which ends in self and does not spend itself on action, they have been neither virtuous nor happy. "Much learning is a weariness of the flesh." Thought without action ends in intense fatigue of the soul, the disgust with all "the sorry scheme of things entire," which is the mark of the unwholesome and insane philosophy of pessimism. This philosophy finds its condemnation in the fact that it has never yet been translated into pure and helpful life.

In like manner sentiment not woven into action fails to be a source of effectiveness or of happiness. "If thou lovest me," said Christ to Impulse and action. Simon Peter, "feed my lambs." Genuine love works itself out in self-spending, in doing something for the help or pleasure of those beloved. Religious sentimentalism, whatever the form it may take, if dissociated from action, has only evil effects. Appeal to the emotions for emotion's sake has been a great factor in human deterioration. Much Degeneration. that has been called "degeneration" in modern social life is due to the predominance of sensory impressions over motor movement. The mind passes through a round of sensations, emotions called up by literature, music, art, religion, which may not have any direct bearing on human conduct. Their aggregate influence on the idle brain is 
always evil. And the misery of motor paralysis, of intellectual pauperism, is felt as the disease of ennui. The remedy for evils of revery, ennui, narcotism, and the like, is to be found in action. The knowledge of this fact constitutes the strength of the Salvation Army movement. The victim of mental deterioration, the "opium fiend," or the inebriate is given something to do. $\mathrm{He}$ is not to wear out the little force he has left in ineffective remorse. Better let him beat a big drum and make night hideous with unmusical song than to settle down to the dry rot of revery or the wet rot of emotional regret. Something to do and the will to act furnishes the remedy for all forms of social or personal discontent.

Not every sense impression can demand distinct response. It is the function of the intellect to sift these The power of attention. impressions, turning over into action only those in which action is desirable or wise. The power of attention is one of the most valuable attributes of the trained mind. And the essential of this power is in the suppression by the will of all impulses which do not concern the present need of action.

As the normal workings of the mind are reducible to sensation, thought, will, and action, so the abnormal workings may be due to defects of any Defects in mental operation.

one of these elements. We may have defects of sensation, defects of thought, vacillation of will, and inaccuracy of action. Hyperæsthesia, anæsthesia, sensory weakness, appear in the uncertain action of the muscles guided by the ill-informed or over-informed brain. The defects and diseases of the brain itself appear in many ways, ranging from oddity or folly to the extreme of idiocy or mania. Most of the "psychic phenomena" along "the borderland of spirit," which occupy a large part in current literature, are char- 
acters of insanity. The phenomena of hysteria, faith cure, openness to suggestion, subjective imagery, mysPhenomena of hysteria. ticism, are not indications of spiritual strength, but of decay and disintegration of the nerves. The ecstasy of unbalanced religious excitement and the stupor of a drunken debauch may belong to the same category of mental phenomena. Both point toward moral and spiritual decay. There are no occult or "latent powers" of the mind except those which have become useless in changed conditions, or which belong to the process of disintegration. If a man crosses his eyes and is thus enabled to see objects double, we do not regard him as having developed a "latent power" of vision. He has simply destroyed the normal co-ordination of such power. One does not increase the strength of a rope by untwisting its strands. The effectiveness of life depends upon the coordination and co-operation of the parts of the nervous system. Its strands must be kept together. To move in a state of revery, "to live in two worlds at once," to be unable to separate memory pictures from realities, all these are forms of nervous disintegration. Every phase of them can be found in the madhouse. The end of such conditions is death. The healthy mind should combat all tendencies toward disintegration. It can be clean and strong only by being true.

In like manner the influence of all drugs which affect the nervous system must be in the direction of disinteEffect of drugs. gration. The healthy mind stands in clear and normal relations with Nature. It feels pain as pain. It feels action as pleasure. The drug which conceals pain or gives a false pleasure when pleasure does not exist forces a lie upon the nervous system. The drug which disposes to revery rather than to work, which makes us feel well when we are not well, 
destroys the sanity of life. All stimulants, narcotics, and tonics which affect the nervous system in whatever way reduce the truthfulness of sensation, thought, and action. Toward insanity all such influences lead; and their effect, slight though it be, is of the same nature as mania. The man who would see clearly, think truthfully, and act effectively must avoid them all. Emergency aside, he can not safely force upon his nervous system even the smallest falsehood. And here lies the one great unanswerable argument for total abstinence; not abstinence from alcohol alone, but from all nerve poisons and emotional excesses. The man who would be sane must avoid, emergencies excepted, all nerve excitants, nerve soothers, and "nerve foods," as well as trances, ecstasies, and similar abnormal relations to the external world. If he would keep his mind he must never "lose his head" save in the rest of normal sleep.

In general, great work is not accomplished under the influence of drugs or stimulants. The great thoughts and great deeds which move the world are those of men who live soberly and whose nervous systems record truthfully the facts of nature and of life.

What is true of man is true of animals, and true of nations as well. For a nation is an aggregation of

The mind of nations. many men as a man is a coalition of many cells. In the life of a nation, Lowell tells us, "three roots bear up Dominion-Knowledge, Will, the third Obedience, the great tap-root of all." This relation corresponds to the nervous sequence in the individual. And as in general the ills of humanity are due to untruthfulness in thought and action, so are the collective ills of nations due to national folly, vacillation, and disobedience. The laws of national greatness expand themselves from the laws which govern the growth of the single cell. 


\section{XI.}

\section{DEGENERATION.}

By degeneration is meant the process by which a living being changes for the worse. This implies a narrowing range of powers and capabilities. The word is opposed in meaning to change for the better, which we call progress or development.

Throughout the animal and vegetable kingdoms may be found instances of degenerate types. There are speDecline in range cies or groups of species which have deof activities. clined in complexity of structure and range of activities as compared with their ancestors. Degeneration of type appears whenever the range of competition is narrowed or incentive to activity lessened. It takes place whenever a relaxation of the struggle for existence permits life on a lower plane of activity or with less perfect adaptation to conditions. Thus a land animal transferred to the sea has its range of activity narrowed. There is competition from fewer quarters, and a corresponding decline of competitive structures takes place.

The most striking cases of degeneration are those of quiescent animals, and parasitic animals and plants, as

Quiescent animals. compared with their free-swimming selfdependent ancestors. Examples of degenerate quiescent animals are the Tunicates. These creatures, descended from fishlike ances- 
tors, are reduced to motionless sacs, buried in the sand or anchored to rocks or wharves. The evidence of their origin is found in the fact that the young Tunicate is Tunicates. tadpole-shaped, with a rudimentary backbone, and has the motions and in large degree the structure of the fish. With the loss of power of locomotion the structures on which locomotion depends also disappear.

Still more marked is the degeneration of parasites. It is a universal rule that all creatures dependent on Parasitical animals. others for support lose their power of self-help. Parasitic insects lose their wings and are confined to the bodies of those unwillingly made their hosts. Parasitic worms are the simplest of their kind. Insects feeding on the juices of plants which they suck without moving become reduced to mere living scales.

Perhaps the most remarkable example of the degeneration of parasitism is that seen in the crustacean Sacculina. called Sacculina. This creature appears as a simple sac attached to the body of the crab, into which its root processes or blood vessels extend. When it is hatched from the egg it is similar in form to a young crab, independent and free-swimming. It soon attaches itself to some adult crab, into the body of which it extends its processes. It loses its power of locomotion, and the limbs all disappear. Living at the expense of others, self-activity is not demanded, and its position protects it from competition to which free-swimming crabs are subject. It becomes degraded into a parasitic sac, with no organs except a nervous ganglion, its ovaries, and root processes. This is the female Sacculina, and parasitic upon this is the smaller and still more degraded male of the same species. 
The Sacculina is the type of race degeneration among animals and plants. When the stimulus to individual activity is lowered and the conditions of Animal pauper- environment are such that destruction ism homologous does not follow reduced activity, we with human pauperism. have continuous degeneration. This is the condition of animal pauperism. The same general laws hold good among men. Inactivity and

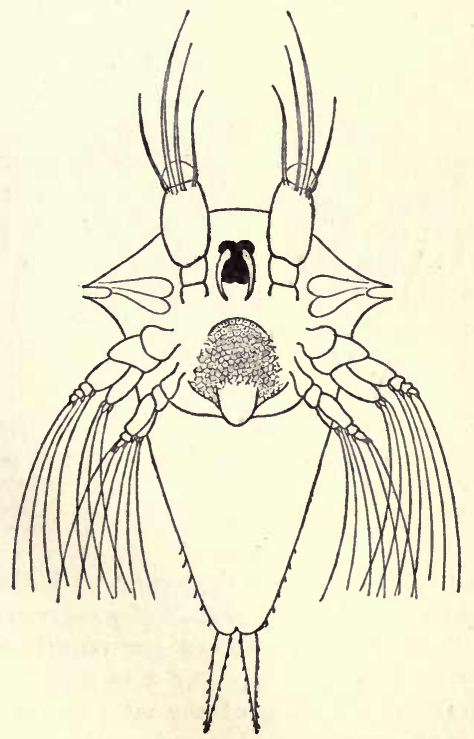

FIG. 19.-Sacculina after leaving the egg. (After Lang.)

dependence, protection in idleness, bring about deterioration and end in weakness, incapacity, and extinction. 
It is true that all adxance in one structure implies degradation of some other. This is the so-called "law

Law of compensation. of compensation." The specialization of the human hand, for example, has been at the cost of the human foot. The power to live by his wits has taken from man something of the strength and spryness of his apelike ancestors.

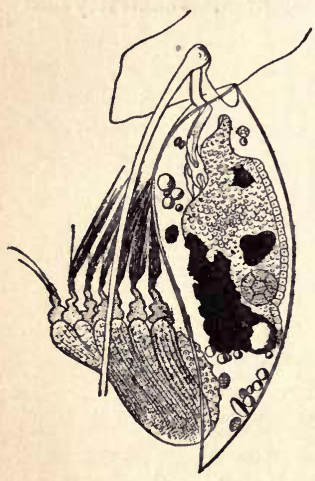
FIg. 20.- Sacculina attach-
ing itself to the crab. (After Lang.)
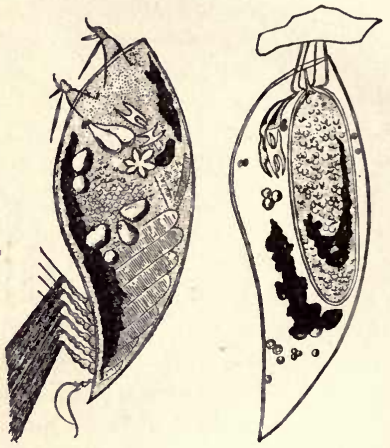

FIG. 21.-Sacculina ; Fig. 22. - Saccuan early stage. lina after absorp(After Lang.) tion of the limbs. (After Lang.)

Any organ tends to degenerate when its highest function loses importance or is replaced by some other. To have one's food cooked means the reduction of the lower jaw and its muscles. For a bird to trust to its wings means the decline of the strength of its feet. Reduction of unused parts is a universal rule in organic development. Decline in all parts is the essential meaning of degeneration.

In the current discussions of the day the word de- 
generation is taking an important part. Degeneration . is known among men as well as among the lower animals

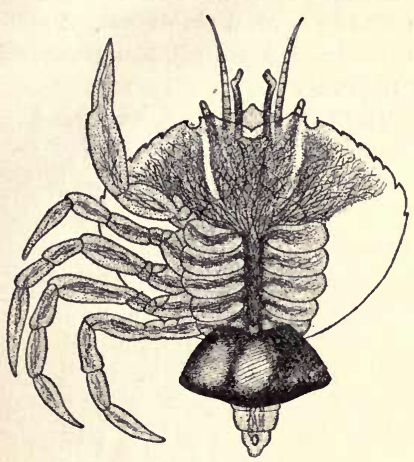

FIG. 23.-Adult Sacculina attached by root processes to the crab. (After Lang.)

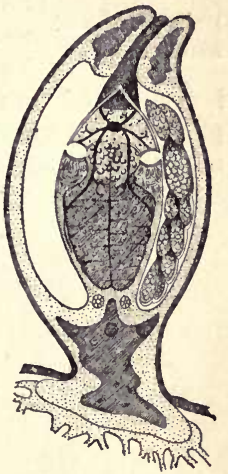

FIG. 24.--Section of mature Sacculina. (After Lang.)

or plants. It is governed by similar laws. The conditions of human degeneration are essentially those of degeneration on lower forms. The causes which will in the long run transform a crab to a Sacculina will make paupers of the descendants of parasitic men. As it is the mind that makes the man, the essence of human degeneration is failure of the nervous structures and functions. It means decline in the accuracy of thought and the veracity of action. The soundness of the machinery of response to external conditions determines, in general, the life and character of man. Degeneration in man is therefore " a morbid deviation from the moral type," so far as nerve functions are concerned.

Personal degeneration comes naturally with the period of old age. The compound animal or "colonial 
organism" must break down sooner or later, man not less than others. Senility brings even to the best some Degeneration of senility.

form of nerve decay. The wisest man must come to second childhood. Senility may come prematurely as a result of influences adverse to mental and physical activity. These influences are manifold and the enumeration

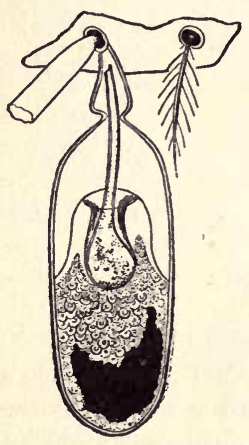

FIG. 25.-Sacculina attached to the crab.

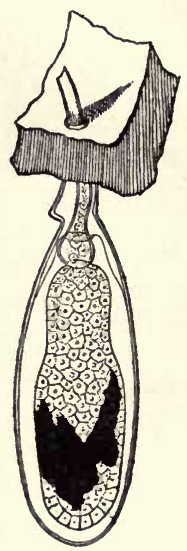

FIG. 26.-Sacculina with limbs absorbed.

of causes and results of the weakness of old age need not be attempted here.

Race degeneration, or continuous decline from generation to generation, may be distinguished from the Race degeneration. wearing out of the individual. The former results from the continuous preservation of the unfit. As the destruction of the unadapted is the chief element of race progress, so is their survival the chief element in race decay. Degeneration occurs when weakness mates with weakness; 
when incentives to individual action are taken away, without reduction in security of life, and when the unfit are sheltered from the consequences of their folly, weakness, or perversity. The increased effectiveness of altruism which goes with race progress furnishes a shelter under which race decay goes on. The growth of wisdom makes folly safe. At the same time the growth of wisdom works the death of fools when they are brought into life-and-death competition with those stronger and wiser.

In the open competition of life the lineage of degeneracy is a short one. Each individual man is a link in the chain of life. His intellect is its Lineage of degeneracy short. guardian. If the safeguard is weak, the link will be broken. Under ordinary conditions of freedom, there is no such thing as bad heredity. Our ancestors are sound and sane each in a fair degree, else we should not have seen the light.

But with all this the withered branch may occur on the most vigorous trees. Some descendant will show

Withered branches. defects in nervous system or in balance of qualities. He will develop weakness or excess in sensitiveness or in motor response, or his mental operations will show a lack of that accuracy we call common sense. Such conditions, if inborn through germ variation, may become hereditary. A degenerate person may under certain conditions be parent of a race of degenerates or "mattoids."

The conditions of preservation of a decaying race may be considered under seven heads.

The unfit may be preserved as objects of charity. "Charity," says a French writer, "causes half the suffering she relieves; but she can not relieve half the suffering she has caused." Unwise charity is responsible for half the pauperism of the world. That pauperism has 
become perpetual is due in part to the charity that, in aiding the poor, helps pauperism to mate with pauper-

Degeneration through charity. ism. It is the duty of true charity to remove the causes of weakness and suffering. It is equally her duty to see that weakness and suffering are not needlessly perpetuated.

Startling results may follow from the selective breeding and preservation of paupers. In the valley of Aosta in northern Italy, and in other Alpine The cretins of Aosta. regions, is found the form of idiocy known as cretinism. What is the primitive cause of the cretin, and what is the causal connection of cretinism with goitre, a disease of the thyroid glands which always accompanies it, I do not know.

It suffices for our purpose to notice that the severe military selection which ruled in Switzerland, Savoy, and Lombardy for many generations took the strongest and healthiest peasants to the wars, and left the idiot and goitrous to carry on the affairs of life at home. To bear a goitre was to exempt from military services. Thus in some regions-the disease has been a local badge of honour. It is said that when iodine lozenges were given to the children of Savoy in the hope of preventing the enlargement and degeneration of the thyroid gland, mothers would take this remedy away from the boys, preferring the goitre to military service.

In the city of Aosta the goitrous cretin has been for centuries an object of charity. The idiot has received generous support, while the poor farmer or labourer with brains and no goitre has had the severest of struggles. In the competition of life a premium has thus been placed on imbecility and disease. The cretin has mated with the cretin, the goitre with the goitre, and charity and religion have presided over the union. The result is that idiocy is multiplied and intensified. The cretin 
of Aosta has been developed as a new species of man. In fair weather the roads about the city are lined with these awful paupers-human beings with less intelligence than the goose, with less decency than the pig.

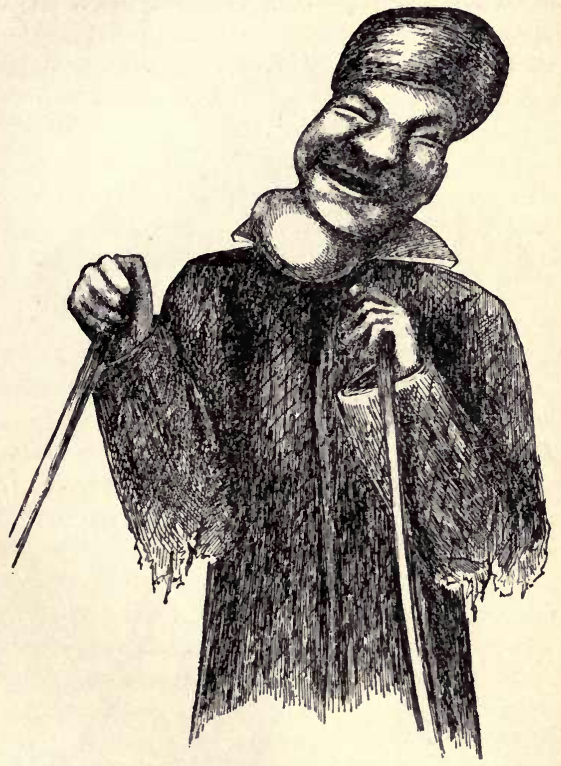

FIG. 27.-A cretin of Aosta. (From a photograph by Dr. J. W. Jenks.)

The asylum for cretins in Aosta is a veritable chamber of horrors. The sharp words of Whymper are fully justified:

"A large proportion of the cretins who will be born in the next generation will undoubtedly be offsprings of 
cretin parents. It is strange that self-interest does not lead the natives of Aosta to place their cretins under such restrictions as would prevent their illicit intercourse; and it is still more surprising to find the Catholic Church actually legalizing their marriage. There is
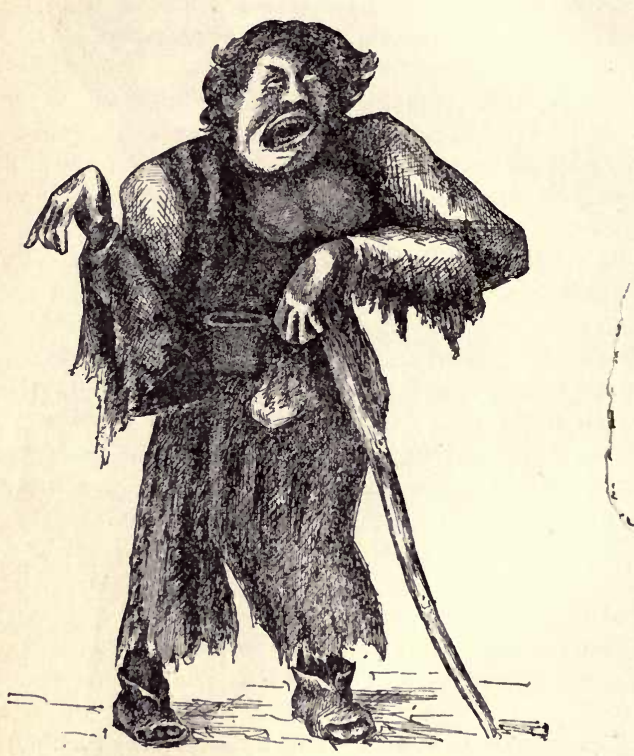

FIG. 28.-A cretin of Aosta. (After Whymper.)

something horribly grotesque in the idea of solemnizing the union of a brace of idiots, and, since it is well known that the disease is hereditary and develops in successive generations, the fact that such marriages are sanctioned 
is scandalous and infamous." (Whymper ; Scrambles among the Alps.)

True charity would give these creatures not less helpful care, but a care which would guarantee that each individual cretin should be the last of his generation.

In isolation as under charity, weakness may mate with weakness and perpetuate degeneration. The clasDegeneration in isolation.

sical studies of Dr. Dugdale into the natural history of the group of degenerates called "the Jukes" shows that the conditions of the slums may be transferred to the forests. Outside of the swift current of life in a shelThe Jukes.

tered nook of the mountains this family of cutthroats and prostitutes found a place for development. The crush of a great city is in some degree an instrument of purification. It brings evil and weakness into close competition with wisdom and strength, and the former come to speedy destruction. The evils of the city rise from corrosion rather than from competition. There is nothing in the pure air of the mountains that will purify the lineage of thieves and paupers. Doubtless the fact of isolation and freedom from stress of competition has been a factor in the preservation of the decaying Jukes, and the same conditions bring about the results in the declining classes driven from the plains to the mountains in other parts of the world. The Great Smoky Mountains are The poor whites. not responsible for the poor whites of the highlands of North Carolina. These people belong to the lineage of England's pauperism transported first to her colonies, afterward driven from the plains to the mountains because of their inability to keep slaves, and since preserved there by their isolation from new currents of life. In like manner, the lowest type of negroes is preserved in the isolation of 
the black belt of the South, the swampy regions near the sea, in which white people can not live, and where the negroes are not subjected to the stress of industrial competition.

The condition of slavery is one favourable for human degeneration. The survival of the docile is its essential feature in slavery. There is no premium Degeneration in slavery.

placed on individuality, no advantage in intelligence, and a positive disadvantage in the impulses of self-direction. A slave can not be a man, and the qualities of manhood are checked and destroyed in slavery.

In the slums of the cities similar conditions obtain. In the life of hopelessness there can be no premium on Degeneration in the slums. hope. The "artful dodger" is a typical product of the natural selection of the slums. To be well born but brought up in the slums means to be born to premature death. The child of the slums, fitted to his environment, must come of the lineage of moral decay.

In the tropics, conditions favouring human degeneration are constantly present. 'The intense heat disDegeneration in the tropics. courages physical or mental activity, while the slight stress of physical surroundings favours the weak, the vacillating, the inert. No premium is placed on effort, and there is developed a type of man to whom effort is impossible. The conditions of degeneration under the tropics closely resemble those seen under ill-advised charity. Nature is too kind and too indiscriminating. As a result, we have as pauper races the descendants of the once civilized and once active Arabs, Egyptians, and Saracens. With the decline of effort goes the failure of personal will, and the growth of the philosophy of fatalism, in which the human will is held to be of no 
worth. It is the will of Allah that the Arab should sleep in filth, and die the death of rottenness. It is related by Edwin H. Woodruff, that not long ago a cesspool in a palace at Cairo was to be cleansed. The vault was opened, and two or three of the workmen were suffocated by the foul gases. "It is Allah's will," said the person in authority, "it is Allah's will that the vault shall not be disturbed." So it was closed again, that its foulness might increase for another century. In the tropics man knows little of competition. He cares not for time. The best man is the laziest, and no civilized race of men has yet held its own under these conditions. The strong races were born of hard times, they have fought for all they have had, and the strength of those they have conquered has entered into their wills. They have been selected by competition and sifted by the elements. They have risen through struggle and they have gained through mutual help, and by the power of the human will they have made the earth their own.

In luxury, again, are found conditions of degeneration. When one has all that he wants, there is little incentive to strive for anything more. Degeneration in When a race is raised above competition, luxury.

there is no premium on the qualities that make for life. The sheltered life does not favour progress. Where the possibility of the misery of want is excluded there is still room for the misery of ennui, the pressure of existence unresisted by effort. Much of that degeneration of the higher classes of Europe, which Nordau has attributed to the "inheritance of fatigue and nerve-strain of civilization," is simply personal and not inherited. It is the natural result of the loss of personal incentive to action. It is the laziness and weakness engendered in the paupered and sheltered life. In the society in which this form of degeneracy appears, 
we find a maximum of sense impressions and a minimum of action. Where thought does not go over into action

Mental

dyspepsia.

a sort of mental dyspepsia is produced. To this abnormal condition the term "degeneration" has been applied, but this name is misleading, because it implies more than the actual truth.

To a phase of degeneration Mr. Israel Zangwill has lately applied the clever designation of "the higher foolishness." By this is meant unbalThe higher foolishness. anced action and expression on the part of people of culture or education. It is act or speech "which makes the judicious grieve," on the part of those supposed to know better. Such people lacking the saving grace of common sense are most of those called by Nordau "degenerates." With these belong the "monkey geniuses" of Dr. Hirsch, the "borderland dwellers" of Dr. Maudsley, the "borderlanders" of Mr. Stead, the "dégénerés supérieurs" of Magnan, the "mattoids" of Lombroso, and, in general, the inspired idiots and educated fools of all ages and climes.

These people have in common the quality of abnormal mental action, verging into insanity on the one hand, to crime on another, and to stupidity on the third. They are, however, distinguished from ordinary idiots, or lunatics, or criminals by some notable quality, by some power of action or expression or attribute of genius, which causes them to attract public notice.

The qualities of these people in relation to art, literature, and religion have been the Nordau on degeneration. subject of the remarkable work by Max Nordau entitled Degeneration.

Nordau's work has the merit of a picturesque style. It has a basis of truth, and contains a veritable mine of 
telling quotations, while nowhere in literature can we find a more merciless arraignment of folly, laxity, and "rot" as expressed in literary or artistic form.

On the other hand, Nordau himself exhibits some of the defects which he criticises. His work shows a decided lack of the sense of perspective. He takes himself, and especially his subjects, too seriously.* $\mathrm{He}$ gives no scientific analysis of the symptoms they show, while causes, effects, symptoms, and imitations alike pass with him as evidences of degeneration. His assumption that degeneration among the higher classes is a phenomenon of our times alone, and his supposition that it is the inheritance of fatigue, nervous exhaustion, and the diseases and degeneration conditioned by them, has but slight foundation. The proposed remedy of Societies for Ethical Culture to act as public judges of literature and art seems puerile, and it is not clear that his proposed Index Expurgatorius of fool-literature would "banish the writings of lunatics from the shelves of all respectable booksellers." It would advertise rather than suppress.

A remedy for degeneration can not be applied in any easy fashion. Sanity is the antidote for insanity, cleanliness of thought and action in life for folly and crime. It is true, as has been said, that "vice, crime, and madness are called by different names only through social prejudice." In like manner virtue, purity, and wisdom are largely convertible terms. The sane man The mattoid. is like a well-made watch-trained to keep correct time under all conditions of temptation, pressure, or environment. The "mattoid" is full of "vibrancy"; he is affected by all sorts

* "There is such a thing as nonsense, and when a man has once attained to that deep conception you may be sure of him ever after."-BAGEHOT. 
of conditions, external and internal. He is like the watch which changes its rate of movement at all sorts of intervals, that will run off the whole twenty-four hours in a minute, and then will not move at all for a day to come. He must have a hard head who would butt against the stone wall of society and make an impression upon it. The sound nervous system is one well buried in skull and flesh. It knows not the "pride of vibrancy," the "bliss of the beautiful," nor the mystic "sensations of the elect mind." It has no love for the "flowers of evil," the "litany of Satan," nor any aspect of what Starr King called the "rotten side of things." It is satisfied with the life and duties of today, and can find pleasure in these rather than in frantic attempts to seize the unknown day after to-morrow.* The sober man will not believe that "that which is profound loves the mask," nor that what actually "occurs is spoiled for art." To him, as to Marcus Aurelius, "the gods are still at the head of the administration, and they will have nothing but the best." So in that part of the universe where he finds himself he finds also his duty.

"The normal man," Nordau wisely says, "with his clear mind, logical thought, sound judgment, and strong The normal man.

will, sees where the degenerate only gropes. He plans and acts where the latter dozes and dreams. He drives him without effort from all the places where the life-springs of Nature bubble up; and, in possession of all the good things of the earth, he leaves to the impotent degenerate the shelter of the hospital, lunatic asylum, and prison in contemptuous pity. Let us imagine the drivelling Zoroaster of Nietsche with his cardboard lions, eagles, and

* “Erst das Uebermorgen gehört mir."-Nietsche. 
serpents, or the noctambulist Des Esseintes of the Decadents, sniffing and licking his lips, or Ibsen's 'solitary powerful' Stockmann and his Rosmer lusting for suicide -in competition with men who rise early, are not weary before sunset, who have clear heads, solid stomachs, and hard muscles."

But in this connection we may remember that competition is not destruction. The degenerates have been helped on by their rivals more than they have been harmed. They have been borne on the shoulders of civilization, and it is the altruism of science which has made their non-science comparatively safe. It is the toleration of the sane that gives the insane the right to live. It is the power of the strong that maintains the weak. In the long run the struggle for existence will destroy the lineage of the decadents of to-day. No shelter can long avail against the "goodness and severity of God." But the folly which now exists is intrenched behind wisdom. The kindness of man postpones the judgments of Nature.

It is not true that "genius is a disease of the nerves," as certain writers have insisted, if by genius is meant forcefulness of any sort. Real effectiveness arises from continuous effort in high directions. We are sometimes astounded by a single product of a man incapable of continuous thought, but the world is not moved by such men, nor has the literature of the ages been produced by them. Great men live great lives. The great work is the great life's impression. There is nothing occult, nothing mystic, nothing hysterical in greatness of mind or heart. Disease of the nerves is not genius; still less is it an attribute of greatness.

Most of the phenomena of decay described by Nordau stand related to mental disease at once as cause, effect, and symptom. Drunkenness, for example, is the 
cause of more drunkenness, of further decay of will. It is the symptom of the decay of will. It is the effect of it. In like manner the love of mysticism grows with its license; the love of filth with what it feeds upon. Egomania increases with self-admiration, sexual madness with its own indulgences. The fantasies of those who "have only to hear of Buddhism to become converts to it" furnish their own arguments and their own justification. Hysteria, catalepsy, and echolalia have many times taken unto themselves the name of religion, and proved the truth of this religion by their own excesses.

Much of the "decadent literature" of the day is not the product of the decadence of man. It is not the effect of the " nerve strain of overwrought Decadence for mercantile purposes. generations born too late in the dusk of the ages." It is simply an unwholesome fashion. Most of it is the work of sane men of mediocre abilities, who throw themselves into grotesque postures in the hope that they may thereby arrest the fickle attention of the public. It is the effort of mountebanks to catch the people's eye. When the public becomes accustomed to froth and symbolism, it is equally surprised and delighted with sweetness and sanity. Neurotic freaks and egomaniacs have been found in all ages. The memory of those of earlier ages has passed away, as those of to-day will be soon forgotten. The end of the nineteenth century has no new form of "the higher foolishness" which the preceding centuries did not know. It can only offer better facilities for publicity than could be had in earlier times. There is money now in the production of literature of decay. In so far as folly and nervous disorder are innate and hereditary, not individual, we have no reason to suppose that they are in any sense a product of the rush of modern civilization. 
Most of the degeneration so cleverly treated by Nordau is purely the result of defects in the life of the individual, in his relation to his environment, and the course of action by which his character is formed. Without going into a detail for which I have neither space nor ability, I may say that the development of mysticism, symbolism, "hearts insurgent," and general mental and moral vagabondage is caused by the lack of sober living and of wholesome work, the lack of motor ideals and of outlet for effort.

In the cities of Europe the common man has risen to a life of larger possibilities and greater opportunities Causes of decadence.

for success and failure without adequate training for such activity. Society is like a band of schoolboys in charge of a railway train. They know not what to do nor how to do it, and are more interested in present enjoyment than in the success of any enterprise intrusted to them. Small-minded men lost in a multiplicity of impressions are likely to do things which suggest degeneration. If to this we add the wide diffusion of corrosive elements, narcotics, stimulants, impure suggestion, unwholesome living, we have elements which tend toward personal degeneration. As their influences affect many persons alike, they appear as a form of social decadence.

We find, moreover, in Europe, the prevalence of "a strange drooping of spirit." This feeling that civilization is confined in a blind channel, a The despondency of Europe.

cul-de-sac, is a natural result of the great increase of the results of sense-perception without corresponding outlet in action. "Progress," says Edward Alsworth Ross, referring to this condition, "seems to have ended in aimless discontent. The schools have produced, according to Bismarck, ten times as many overeducated young men as there are places to 
fill. The thirst for culture has produced a great hungry intellectual proletariat. The forces of darkness are still strong, and it seems sometimes as if the middle ages would swallow up everything won by modern struggles. It is true that many alarms have proved false, but it is the steady strain that tells on the mood. It is pathetic to see on the Continent how men fear to face the future. No one has the heart to probe the next decade. The outlook is bounded by the next Sunday in the park or the theatre. The people throw themselves into the pleasures of the moment with desperation of doomed men who hear the ring of the hammer on the scaffold. Ibsen, applying an old sailor's superstition to the European ship of state, tells how one night he stood on the deck and looked down on the throng of passengers, each the victim of some form of brooding melancholy or dark presentiment. As he looked he seemed to hear a voice crying, "There's a corpse on board!"'

The record of degeneration in music, in art, in literature, in religion as traced by Nordau, is the record of loss of hope and loss of illusion. In so far as it is honest, not a mere affectation, it is the cry called out by the misery of personal or social decay. It is the expression of mental dyspepsia and physical impotence. It finds a large part of its explanation in the fact that, with the class affected by it, sense-impressions, feelings, and impulses have far outrun the opportunities for action. The cure for this condition is found in ambition, effort, individual development. It is not the swift rush and whirl of modern civilization which has brought all this to pass. It has come rather from attaining the results of this rush* without taking part in its effort.

* A similar thought is expressed by Kant, as quoted by Mark Pattison. Of "Schwärmerei," or philosophical revery, he says : "This mental disease arises from the growth of a class which has 
The genuine man, the man who is doing something, who faces " the world as it is," in absolute veracity of thought

The man of force. and action, is never decadent. Society lives through the effort of those who have power to act beyond what is needed in the common struggle for life. Strength begets strength and wisdom leads to wisdom. "There is always room for the man of force, and he makes room for many." It is the strong, wise, and good of the past who have made civilization possible. It The wholesome is the great human men, the "men in world. the natural order," that now and for all time determine the current of life. "The earth," Emerson tells us, "is upheld by the veracity of good men. They keep the world wholesome."

From all institutions a certain form of degeneration must arise, because all institutions tend in some degree to do away with individual effort. A Degeneration common creed for men weakens the under institutions.

force of individual belief. Common ceremonies destroy the spontaneity and personality of the feelings they represent. Right action by statute and convention is in some degree opposed to virtue by personal initiative. Between unregulated individualism or anarchy and all-controlling institutions

not yet thorough science, yet is not wholly ignorant. It has caught up notions on current literature which makes it think itself on the same level of those who have laboriously studied the sciences. I see no other means of checking the mischief, except that the schools should reform their method and restore thorough teaching instead of that teaching of many things which has usurped its place." Thoreau speaks of the derivation of "vile" and "villain " from via, way, and villa, village. "This suggests," he says, "that kind of degeneracy villagers are liable to. They are wayworn by the travel that goes by and over them without travelling themselves." 
or slavery there must always be a just mean. To find and maintain this just mean from generation to generation is the function of social reform. The reform of the day has been always in the direction of greater personal freedom. "As a snow bank grows where there is a lull in the wind," says Thoreau, "so where there is a lull in the truth, institutions spring up; by and by the truth blows over them and takes them away." All forms of tyranny have their beginning in kindness. Paternalism in time hardens into oppression and checks the growth of the individual man, who should become responsible to himself and for himself. The intelligence and freedom of one's neighbours, not the force of statute nor the power of arms, are the guarantee of social security.

Causes of pauperism may be found in other forms of giving as well as in those recognised as charity. Mental pauperism is produced when men are given truth instead of being trained to search for it. There are schools which tend to make intellectual paupers instead of training men to think for themselves. There is a moral pauperism induced by the giving of precepts. Right conduct must be individual if it is to have stability. The doing of an honest piece of work honestly may have more force in moral training than a hundred sermons. In like manner spiritual pauperism may be produced by religious instruction. Each man must make his own religion. He must form his own ideals. In the degree that he is religious he must in time become his own high priest, as in the degree that he is effective he must be his own king. 


\section{XII.}

\section{HEREDITARY INEFFICIENCY.}

THis world is not, on the whole, a hard world to live in if one have the knack of making the proper concesThe art of living. sions. Hosts of animals, plants, and men have acquired this knack, and they and their descendants are able to hold their own in the pressure of the struggle for existence. This pressure brings about the persistence of the obedient, those whose activities accord with the demands of their environment. This persistence of the adaptive is known as the survival of the fittest, which has through the ages been the chief element of organic progress. Among men there have always been those to whom the art of living was impossible. This has been the case under ordinary conditions as well as under extraordinary ones. It must be the case with some under any conceivable environment or any circumstances of life. Some variations must tend in the direction of incapacity. This incapacity of one generation, if inborn and not induced by disease or malnutrition, may be handed down by the law of heredity to the next.

In one way or another, in time, most of the incapables are eliminated by the process of natural selection. But not all of them. Our social system is bound too closely. Hereditary incapacity of the few has been in all ages a burden on the many who could take care of 
themselves. With higher civilization and an increasing recognition of the value of mutual help it is becoming

Mutual help preserves the incapable. more and more possible for those to live who do not help. The descendants of these increase in number with the others. They are protected by the others. Thus the future of hereditary weakness is a growing problem in our social organization.

Of course the conditions of life have never yet made the "survival of the fittest" the real survival of the The easy world. best. The growth of civilization approaches this end, but has never reached it. If this were reached, adaptation to the conditions of life would be a nobler process than it now is. It is not that the conditions of life are too hard. We would not make them easier if we could. But the welfare of humanity demands that they be made more just. An easier world would be one in which idleness, vice, and inefficiency fare better than now, and energy, virtue, and efficiency correspondingly worse. The premium natural selection places on self-activity and mutual help is none too great at the best and should not be lessened. Nature is over-indulgent toward idleness rather than too cruel. The degradation of life in the tropics comes because in those regions the stress of the human struggles is distinctly lowered. The real "City of the Dreadful Night " is not noisy, eager, struggling, unjust London. It is some city of the tropics where action and virtue count for nothing because there is no incentive to live a life worth living, and no adequate penalty for stagnation and inefficiency.

It is easy to frame indictments against modern society and its organization. We may see it as weak, tyrannical, depressing, artificial, cruel, or unjust, as we may give attention to its least favourable manifestations. 
Nevertheless, the social organism of Europe and America is as good as man has been able to make it. In the evolution of man it has been a long struggle to attain even what we have. Better conditions will be possible through better material in humanity. Better relations demand better men. The more perfect the organism, the more evident are its deviations from perfect adaptation.

It may be that in the conditions of life failure is not due to any defect of the individual. Its cause has often arisen in injustice and oppression which sometimes makes the just, the brave, the wise man an outcast from society. Such conditions and such failures occur in the life of to-day. But under ordinary conditions those who fail in life do so because of the lack of ability to make themselves useful to others, or for lack of ability to place themselves in harmony with the forces of $\mathrm{Na}$ ture with which they are surrounded. In other words, most of those who fail are doomed to perish wherever there exists any form of competition, and no life is without it. The inert, untrained, ignorant, or vicious are constitutionally unsuccessful, and from conditions which these names themselves imply. Those who thus fail to do their part in the struggle of life must become a burden to be carried by others or else they perish, the victims of misery they can make no efforts to avoid. Those who are carried by society as burdens may be roughly classified as paupers and criminals - those whom society voluntarily supports and those supported through society's lack of means of self-protection. Pauperism and habitual criminality are respectively passive and active states of the same disease.

In this sense pauperism is not by any. means the same as poverty. Poverty is the absence of stored-up economic force. It may arise from sickness, accident, 
or from various temporary conditions. The person now

Poverty not pauperism. subject to poverty may have within himself the cure for it. The pauper can not cure himself, and all help given him but intensifies his pauperism.

There are various conditions-sickness, dissipation, the weakness of age, evil associations-that may plunge the average man from poverty into pauperism. We are none too well equipped for the struggle for life at the best, and the loss of weapons or armour may make any man helpless for the time being. But some are helpless from birth. There is in every nation a multitude of men and women to whom fitness is impossible. In the submerged tenth of every land may be found the broken and stricken, the ruined in body and spirit. But the majority of these have never been, could never be, anything else than what they are. They are simply incapable, and they are the descendants of others who in similar conditions have been likewise incapable. In a world of work where clear vision and a clear conscience are necessary to life they find themselves without sense of justice, without capacity of mind, without desire for action. They are born to misery, and the aggregate of misery would be sensibly lessened had they never been born.

It is a fact of biology that whenever any series of organisms are withdrawn from active life and the proDegeneration of the inactive. cess of natural selection no longer offers a premium for self-activity, degradation sets in. Organs are lost as their functions are abandoned. In this way the descent of the inert barnacle from the active crablike forms is accounted for. In similar manner the degraded parasitic Sacculina is shown to be of crustacean or crablike origin. The young Sacculina and the young crab are 
essentially alike for a period after their birth. The crab continues and develops an active life. The Sacculina thrusts its feelers into the body of the crab on which it is to feed. Its organs of eating and swimming disappear. All structures connected with independent life become atrophied, and finally nothing is left of the Sacculina except its saclike body, its feelers or roots ramifying through the blood vessels of the crab, and its reproductive organs by which the brood of parasites is kept alive. When the habit of parasitism is once established, the struggle for existence simply intensifies it from generation to generation.

The fittest Sacculina is the most degenerate one. In like manner whenever a race or family of men has fallen away from self-helpfulness the forces of evolution intensify its parasitism. The successful pauper is the one who retains no capacity for anything else. The loss of all other possibilities is the best preparation for the life of the sneak thief.

Recent studies, as those of Dugdale, McCulloch, and others, have shown that parasitism is hereditary in the human species as in the Sacculina. McCulloch has selected the Sacculina for special illustration of the results of like processes in the human family. Like produces like in the world of life. Those qualities in the grandparent which made him an outcast from society or a burden upon it reappear in the father and again in the son. As in one case, so in the others, they determine his relation to society. The pauper is the victim of heredity, but neither Nature nor society recognises that as an excuse for his existence. The forces of Nature take no account of motive and are no respecters of persons. Dugdale has shown that parasitism, pauperism, prostitution, and crime reappear generation after generation in the descendants of "Margaret, the mother 
of criminals." Oscar C. McCulloch, speaking of the descendants of a pauper family named "Ishmael," in the city of Indianapolis, uses the following language:

"We start at some unknown date with thirty families. These came mostly from Kentucky, Tennessee, The tribe of Ishmael. and North Carolina. Of the first generation-of sixty-two individuals-we know certainly of only three. In the second generation we have the history of eighty-four. In the third generation we have the history of two hundred and eighty-three. In the fourth generation-18401860 - we have the history of six hundred and fortyfour. In the fifth generation-r860-1880-we have the history of six hundred and seventy-nine. In the sixth generation-r880-1890-we have the history of fiftyseven. Here is a total of seventeen hundred and fifty individuals. Before the fourth generation-from 1840 to 1860 -we have but scant records. Our most complete data begin with the fourth generation, and the following are valuable. We know of one hundred and twenty-one prostitutes. The criminal record is very large-petty thieving, larcenies chiefly. There have been a number of murders. The first murder committed in the city was in this family. A long and celebrated murder case, known as the 'Clem' murder, costing the State immense amounts of money, is located here. Nearly every crime of any note belongs here. Between I 868 and 1888 not less than five thousand dollars has been paid for 'passing ' these people from place to place, each township officer trying to throw off the responsibility. The records of the city hospital show thattaking out surgical cases, acute general cases, and cases outside the city-seventy-five per cent of the cases treated are from this class. The number of illegitimacies is very great. The Board of Health reports that the 
number of stillborn children found in sinks, etc., would not be less than six per week. Deaths are frequent, and chiefly among children. The suffering of the children must be great. The people have no occupation. They gather swill or ashes; the women beg, and send the children around to beg; they make their eyes sore with vitriol. In my own experience I have seen three generations of beggars among them. I have not time here to go into details, some loathsome, all pitiable. One evening I was called to marry a couple. I found them in one small room with two beds. In all eleven people lived in it. The bride was dressing, the groom washing. Another member of the family filled a coal-oil lamp while burning. The groom offered to haul ashes for the fee. I made a present to the bride. Soon after I asked one of the family how they were getting on. 'Oh, Elisha don't live with her any more.' 'Why?' 'Her husband came back, and she went to him. That made Elisha mad, and he left her.'

"All these are grim facts, but they are facts and can be verified. More, they are but thirty families out of a possible two hundred and fifty. The individuals already traced are over five thousand, interwoven by descent and marriage. They underrun society like devil grass. Pick up one, and the whole five thousand will be drawn up. Over seven thousand pages of history are now on file in the Charity Organization Society.

- "A few deductions from these data are offered for your consideration. First, this is a study into social degeneration, or degradation, which is similar to that sketched by Mr. Lankester. As in the lower orders so in society, we have parasitism, or social degradation. There is reason to believe that some of this comes from old convict stock which England threw into this country in the seventeenth century. We find the wandering 
tendency so marked in the case of 'Cracker' and the 'Pike' here. 'Movin' on.' There is scarcely a day that the wagons are not to be seen in our streets; cur dogs; tow-headed children. They camp outside the city, and then beg. Two families as I write have come by, moving from north to south, and from east to west, 'hunting work,' and yet we can give work to a thousand men on our gas trenches.

"Next, note the general unchastity that characterizes this class. The prostitution and illegitimacy are large; the tendency shows itself in incests and relations lower than the animals go. This is due to the depravation of Nature, to crowded conditions, to absence of decencies and cleanliness. It is an animal reversion which can be paralleled in lower animals. The physical depravity is followed by physical weakness. Out of this come the frequent deaths, the stillborn children, and the general incapacity to endure hard work or bad climate. They can not work hard, and break down early. They then appear in the county asylum, the city hospital, and the township trustee's office.

"Third, note the force of heredity. Each" child tends to the same life, reverts when taken out.

"And, lastly, note the influence of the great factor, public relief. Since 1840 relief has been given to them. At that time we find that 'old E. Huggins' applied to have his wife Barthemia sent to the poorhouse. A premium was then paid for idleness and wandering. The amount paid by the township for public relief varies, rising as high as $\$ 90, \infty 00$ in 1876 , sinking in 1878 to $\$ 7, \infty 00$, and ranging with the different trustees from $\$ 7,000$ to $\$ 22,000$ per year. Of this amount, fully three fourths has gone to this class. Public relief, then, is chargeable in a large degree with the perpetuation of this stock. The township trustee is practically unlim- 
ited in his powers. He can give as much as he sees fit. As the office is a political one, about the time of nomination and election the amounts increase largely. The political bosses favour this and use it-now in the interests of the Republican now of the Democratic party. It thus becomes a corruption fund of the worst kind. What the township trustee fails to do, private benevolence supplements. The so-called charitable people who give to begging children and women with baskets have a vast sin to answer for. It is from them that this pauper element gets its consent to exist."

In every American city, as in Indianapolis, there exist a large number of people who, in the ordinary

Paupers as parasites. course of life, can never be made good citizens. Our free institutions do not make them free; our free schools do not train them; our churches do not contain the means of their salvation. It is well to face the fact that the existence of the great body of paupers and criminals is possible only by feeding them in one way or another on the life-blood of the community. It is the presence of this class which adds terror to poverty. It is they which make intolerable the lot of the worthy poor. The problem of poverty and misfortune is a difficult one at best. It is rendered many times more difficult by the presence among the poor of those whom no condition could bring to the level of self-helpful and self-respecting humanity. The difficult problem of the unemployed becomes far more difficult when associated with the hopeless problem of the unemployable.

It is not important to our present discussion to consider how these conditions arose. It may be a defect of human society that the law of natural selection has not had its perfect work. The destruction of the unfit has not kept pace with their power of reproduction. 
We may blame the kind influence of charity for lack of discrimination in its efforts for the help of our neighbours. The indiscriminate charity of the middle ages is responsible for much of the misery of ours. It is only in very modern times that charity has had any relation with justice. It is only lately that science has shown that charity is to be judged not by its motives but by its results. "Charity, falsely so called," says McCulloch, "covers a multitude of sins, and sends the pauper out with the benediction, 'Be fruitful and multiply.' Such charity has made this element, has brought children to birth, and insured them a life of misery, cold, hunger, sickness. So-called charity joins public relief in producing stillborn children, raising prostitutes, and educating criminals."

Whatever the causes of hereditary inefficiency, it exists in our civilization. It is part of our social fabric. It is an element not less difficult than the race problem itself. The race problem is indeed a phase of it, for when a race can take care of itself it ceases to have a problem.

Hereditary inefficiency is therefore a factor in society. It must be considered as a factor in civil affairs.

Pauperism a factor in government.

In what way does it affect the problem of government? In municipal government its evil effects are at once apparent. A single group of related families, all helpless and hopeless by heredity, forms in the clean and wealthy city of Indianapolis some four per cent of the population-5,000 in perhaps 125,000 . In other American cities, notably in San Francisco, with its mild climate and proverbial hospitality, the percentage is greater, for more of these families are represented. In no city are they absent. Self-government by such people is a farce. No community was ever built up of thieves and imbeciles. The vote of the dependent classes 
is always purchasable. The co-ordination and sale of this vote and of the allied criminal vote are the work of the most dangerous of the dirty brood of political bosses. It is the stock in trade of every king of the slums. This vote can be bought with the money of candidates. It can be bought with the spoils of office. It can be bought with public funds set aside for purposes called charity.

The various forms of outdoor relief constitute, as McCulloch has shown, "a corruption fund of the worst Corruption fund of public charity. kind." The United States has virtually failed in the management of her cities. This failure is most complete where the manipulators of paupers and criminals are boldest and most effective; moreover, the effluvium of municipal corruption flows out and poisons the politics of the state and the nation.

Every venal, cowardly, or ignorant voter is a menace to the safety of republican institutions. The essential purpose of popular suffrage is not to secure good government, but to produce an interest in civil affairs that will sooner or later bring about good government. This growth in civic knowledge is impossible without a foundation of intelligence. The choice of negro suffrage was the wisest choice among the many evils having their rise in negro slavery. It was the least of the evils, no doubt, but an evil nevertheless. Every evil is likely sooner or later to become a festering sore in the body politic.

The dangers of foreign immigration lie in the overflow to our shores of hereditary unfitness. The causes

Foreign immigration. that lead to degeneration have long been at work among the poor of Europe. The slums of every city in the Old World are full of the results. Apparently few cases of hereditary inefficiency exist in America that could not 
be traced back through pauper lineage to dependent classes in the Old World. It takes many generations to found a pauper stock. Misfortune, sickness, intemperance, the weakness of old age, often lead to poverty and personal misery. Personal causes do not lead to hereditary pauperism. The essential danger of unrestricted immigration is not in bringing in an alien population strange to our language and customs. Language and customs count for little if the blood is good. The children learn our language, even to the forgetting of their own. Love of our country is just as genuine in Norwegian or German dialects as it is in English or Irish. There is little danger either in violent opinions or iconoclastic theories. The red flag of anarchy will not long wave where real oppression does not exist.

But the immigration of poverty, degradation, and disease make government by the people more and more difficult. Every family of "Jukes" and "Ishmaels" which enter at Castle Garden carries with it the germs of pauperism and crime. They bear the leprosy and crime of the Old World to taint the fields of the New. The "assisted immigration" at Jamestown years ago has left its trail of pauperism and crime from Virginia across Carolina, Kentucky, Indiana, Missouri, even to California, Oregon, and Hawaii. Wherever its blight has gone there are the same inefficient men, sickly women, frowsy children, starved horses, barking cur dogs, carelessness, vindictiveness, and neglect of decency.

Withdrawal from the competition of life, withdrawal from self-helpful activity, aided by the voluntary or involuntary assistance from others-these factors have made that which McCulloch calls "the tribe of Ishmael." These conditions bring about the same results in all ages and among all races, among the lower animals as well as among men. The same effects of simi- 
lar causes are seen in the decline of royalty and nobility of Europe as well as the degradation of European cretins and thieves. There is no development without activity, and no race is so perfect that judicious weeding out could not improve it.

What can be done to remedy this source of evil? To know the evil is to go half way toward its cure. Penal reform, charities reform, civil-service reform, the prohibition of pauper immigration, education in social science-all these look in the direction of cure. In knowledge lies the surest remedy for most social and political evils. Let us see our enemy Taking away the "freedom which is thraldom to sin." face to face and we can strike him. What more can be done is the work of students of social science to determine. Dr. Amos G. Warner has well said that the "true function of charity is to restore to usefulness those who are temporarily unfit, and to allow those unfit from heredity to become extinct with as little pain as possible." Sooner or later the last duty will not be less important and pressing than the first. Good blood as well as free schools and free environment is essential to the making of a nation. 


\section{XIII.}

THE WOMAN OF EVOLUTION AND THE WOMAN OF PESSIMISM.

THE primary function of sex is the production of variation. Unlikeness among organisms makes possible Primary meaning of sex. an increased number. With variety of qualities there is room for variety in adaptation to the possible conditions of life. With single parentage or parthenogenesis the young will resemble the parent so exactly that the competition one with another must be of the closest possible kind. In the degree that competition is close it must be destructive. With double parentage no organism can be a slavish copy of any other. Each creation must in the nature of things have twice as many ancestors as either parent had, and from these ancestors the mosaic of its hereditary character must be made up.

In the beginning of life, so far as we know, the two sexes must have been identical. From the point of view of evolution neither can be superior nor prior to the other. Each is complementary to the other; the differences which have arisen in the progress of develop-

Primal equality of sexes. ment being responses to the needs of division of labour.

The cells of Protozoa which unite in the function of conjugation are apparently alike as to sex. Their union serves to modify the hereditary char- 
acters of their descendants. To have two parents instead of one is to widen the range of possible variation.

With time this identity of the two elements in parentage disappears. It gives way to specialization, reSpecialization of germ cells. sulting in a division of function between the two sexes and the distinction of germ cells from other cells. The germ cell in the higher creatures gains characters and qualities of its own not possessed by the other cells of the body. As the character of double parentage is retained in the development of the higher animals and plants, it too is specialized and perfected. "Nature," says Weismann, "has no better way of encouraging variation than by preventing individual units from developing alone."

In the germ cell of the female, known as the egg or ovum, food yolk is deposited for the use of the young organism. This burden reduces the activity of the female cell. It becomes sessile and motionless. Its cognate, the male germ, on the other hand, is specialized to seek the egg cell. It is made up of an almost bare nucleus to which is attached a vibratile structure which gives it the power to move.

This differentiation of sex in the germ cell produces changes and reactions in the organism from which it proceeds. The egg-bearing sex becomes in comparison with the other sessile, expectant, conservative. The feeding of the young and its protection from external enemies falls to the lot of the female. The male becomes in varying degree the food winner, the fighter, the one which struggles against outside foes. Greater physical strength is co-ordinated with the need for greater activity. Increased force demands increase of size of body. Increased muscular development necessitates increase in size of the sensorium or brain which controls it. 
The process of evolution makes the embryo more and more important; specialization checks waste. Among the higher forms the loss of ova and of embryos becomes less and less; correspondingly fewer in number are needed.

To bring forth the young alive and to nourish it with milk is greatly to reduce the waste of life. It renders a Specialization of the embryo. birth important. The fox, in the fable, once reproached the lioness that she brought forth but one young one at a time. "Yes," she said, "but that one is a lion." To bear the young and to nourish it separates the lioness further and further in function from the lion. This handicap of her general activities in the interest of the coming generation throws greater stress on his. Should she neglect her duty, her line of descent would be cut off. Hence the coming generations are derived from those who do not shrink from the self-sacrifice which parenthood demands. What is true of the lower animals is true of man in still higher degree. It is the basis of the recognised distinctions in the activities of men and women. That every child born should make the most of itself is the ideal of social development. As society advances, father and mother must furnish more and more of the environment of the child. The merely physical part of parenthood assumes an importance progressively less and less. The higher heredity which each individual builds up for himself should be well under way when parental influences cease. The aggregate of these influences constitutes the home.

The duty of home-making must fall on the mother. This is demanded of civilized women, that they shall be fit for mothers, not merely for nurses Maternity and companionship. and cooks and chambermaids. They must be fit for the lifelong environment of the strongest and wisest men. 
It is not just to regard the male as the normal type of humanity, and woman as a modification or degradation of it.

"Woman is not undeveloped man, but diverse." Woman not undeveloped man. Each sex is differentiated, in its degree, from the intermediate unsexed type, which of itself never existed, save in the one-celled protozoan.

Because of the needs of life, man has been differentiated in motor directions, woman in directions of feeling and response. Man has been compelled to face external Nature. Woman must face humanity. Thus the initiative in action is thrown more and more on the male; the response of feeling on the female.

In this division of labour mental and physical characters are correlated. Women excel in delicacy, in devotion, in sympathy. They are not noted as explorers of new fields. As investigators, inventors, judges, or warriors their efforts are on the whole ineffective. Such activities are not in the line of duty assigned them in the division of labour. As defender of the young, the female puts the male to shame. No creature is so dangerous as the female beast at bay. The defender of the young or the weak must be a partisan, not a judge.

If we can use such terms in relation to a process of Nature, we may say that the noblest results of evolution are to be found in the altruism of parenthood. The development of the "eternal womanly," the difThe altruism of parenthood. ferentiation of the mother and wife, carries within itself the full compensation for all that it has cost.

As against this view which I have briefly presented it may be interesting to contrast the view of woman presented by the philosophy of pessimism, through its ablest exponent, Arthur Schopenhauer. 
The point of view of the intellectual movement known as Pessimism may be here briefly discussed.

"To see all things as they really are," to do away with all delusions, is the avowed purpose of pessimism.

The philosophy of pessimism.

To the extent that it would bring men

from dreams to realities, from superstition to science, it has served a high purpose. It doubtless represents a great intellectual advance over the crude optimistic theories which it was intended to supersede. In the light of pessimism the present moment is but a shadow passing across the face of eternity. Human power and glory and happiness are but transitory illusions. Pain and sorrow, which lie behind these at all times, are the only realities in life, for whenever the mind comes in contact with reality, pain is the inevitable product. Under the search light of pessimism, taints and defects are visible everywhere in the human body and soul, and in the equally human state. As everything we know is petty and ineffective and bad, it is as bad as it can be, and this world is the worst world possible. To us, impotent to know, impotent to do, and impotent to enjoy, the present moment has nothing to offer, and there is no other. If the Creator be all-wise, he can not be all-good, else some kinder fate would be reserved for man.

From the standpoint of evolution, on the other hand, "every meanest day is the conflux of two eternities." Every object in Nature, every event The philosophy in human life, represents the meeting of evolution.

points of world forces, that have welled upward since the beginning of time. We are to know things as they really are, for the sake of knowing what they may become, and the forces of which they are the product. While pessimism concerns itself with things, evolution deals with forces, the unchanging realities by 
which the changing facts of life are endlessly produced. A child is only a child to pessimism, a mere human larva, heir to all the defects of human nature, and bound to run the course over which its ancestors have been unwillingly and ineffectively driven. In the light of evolution the child has all the grand possibilities of thought and action and love that go to the making of a man. It sees it not as what it is but as what it may become. And in the light of evolution, human life may be judged not by its failures, but by the strongest and most harmonious representatives of humanity. In the defects of church and state may be read the higher ideals for which men are striving. In the broken ideals of the ethical life may be read the forces inside ourselves "which make for righteousness," and which are the realities in life, rather than the acts of greed and failures of will which make up the sad facts of human existence.

In his remarkable essay on woman, Arthur Schopenhauer takes her character and relations as the basis of Schopenhauer's essay on woman.

a most caustic analysis. Discarding all illusion and romance, the "present, poor and bare," is allowed to "make its sneering comment" on "the eternal womanly," and it is found to be poor stuff. Schopenhauer finds woman Woman a to be merely a form of man, modified modified man.

by Nature, to make real men possible and comfortable. "Without woman," he quotes from Jouy, "the beginning of life would be helpless, the middle without pleasure, the end without consolation."

According to Schopenhauer,* "woman is capable of no great labour of mind or of body." Her "debt of

* In the paragraphs which follow, the language of Schopenhauer is much condensed, only enough being quoted to give the substance of the original statements. 
life is paid not by what she does, but by what she suffers." "Sorrow and joy and action are not for her Inefficiency of gentle, peaceful, and trivial life." As woman. nurse or teacher woman of ten excels, because by nature she is childish, frivolous, and short-sighted. For these reasons she comes near to the hearts of children and invalids.

When women are young, according to Schopenhauer, they attract men strongly but without reason. "With

Beauty of young girls.

young girls Nature seems to have had in view what in the language of the drama is called a striking effect, as for a few years she dowers them with a wealth of beauty and is lavish in her gifts of charm at the expense of all the rest of their life, so that during those years they may capture the fancy of some man to such a degree that he is hurried away into undertaking the honourable care of them in some form or other as long as they live-a step for which there would not appear to be any sufficient warrant if reason only directed his thoughts.

"Accordingly, Nature has equipped woman, as she does all her creatures, with the weapons and implements

Beauty as a weapon. requisite for the safeguarding of her existence, and for just as long as it is necessary for her to have them. Here, as elsewhere, Nature proceeds with her usual economy, for just as the female ant after fecundation loses her wings, which are then superfluous, nay, actually a danger to the business of breeding, so, after giving birth to one or two children, a woman generally loses her beauty, probably, indeed, for similar reasons.

Triviality of women.

"And so we find that young girls in their hearts look upon domestic affairs or work of any kind as of secondary importance, if not actually as a mere jest. The only 
business that really claims their earnest attention is love, making conquests, and everything connected with this-dress, dancing, etc.

"The more noble and perfect an animal," he continues, "the later is its maturity. The development of Early maturity of women.

woman's reason ceases at eighteen, while that of man is imperfect before the age of twenty-eight. Woman's reason is accurate only as to objects which are quite near. In other regards she mistakes appearance for reality and trifles for truth." Man looks "before and after" and considers the ultimate result of lines of conduct. From this forethought he acquires prudence, and this makes care and anxiety possible. Woman is short-sighted and extravagant; her vision is clear a short way only. Hence women are more cheerful than men, because they live in the present, not in the past; nor are they distressed by the future. But with all this it is well for a man to heed a woman's advice, for she will show him the shortest road to the goal. Men see far in front of their noses and miss that which is close and obvious. Hence women are more sober in judgment, having no imagination.

Women are kind to the unfortunate because they have no sense of justice. Most misfortune is criminal Kindness of women. negligence, Schopenhauer argues, and excludes pity, which would be treachery to justice. Fixed rules of conduct are unknown to women. Being weaker in body and mind, they are stronger in craft. The art of dissimulation is Deceit of women.

possessed by all women, stupid as well as clever. "Small secrecy verging on deceit," says Charles Reade, "thou art bred in woman's bones."

"For," says Schopenhauer, "as lions are provided 
with claws and teeth, and elephants and boars with tusks, bulls with horns, and the cuttle-fish with its cloud of inky fluid, so Nature has equipped woman for her defence and protection with the arts of dissimulation. Hence dissimulation is innate in woman, and almost as much a quality of the stupid as of the clever. It is natural for them to make use of it on every occasion, as it is for those animals to employ their means of defence they are when attacked; they have a feeling that in doing so they are only within their rights. Therefore a woman who is perfectly truthful and not given to dissimulation is perhaps an impossibility, and for this very reason they are so quick at seeing through dissimulation in others that it is not a wise thing to attempt it with them."

Women, moreover, live for the species, not for the individual. If a woman be faithless to an old or unroWoman lives for the species. mantic' or inattentive man she will feel no remorse. It is her instinct to consider the interest of the species, not of the person who may represent the species for the time being.

"And since women exist in the main solely for the propagation of the species and are not destined for anything else, they live, as a rule, more for the species than for the individual, and in their hearts take the affairs of the species more seriously than those of the individual. This gives their whole life and being a certain levity; the general bent of their character is in a direction fundamentally different from that of the man; and it is this which produces that discord in married life which is so frequent and almost the normal state.

"The natural feeling between men is mere indifference, but between women it is actual enmity. The reason of this is trade jealousy, which, in the case of 
men, does not go beyond the confines of their own particular pursuits, but with women embraces the whole sex, since they have only one kind of business. Even Trade jealousy among women. when they meet in the streets women look at one another like Guelphs and Ghibellines; and it is a patent fact that when two of them make first acquaintance with each other, they behave with more constraint and dissimulation than two men would show in a like case; and hence it is that an exchange of compliments between two women is a much more ridiculous proceeding than between two men. Further, while a man will, as a general rule, always preserve a certain amount of consideration and humanity in speaking to others, even to those who are in a very inferior position, it is intolerable to see how proudly and disdainfully a fine lady will generally behave toward one who is in a lower social rank (I do not mean a woman who is in her service) whenever she speaks to her. The reason of this may be that with women differences of rank are much more precarious than with us, because, while a hundred considerations carry weight in our case, in theirs there is only one-namely, with which man they have found favour, as also that they stand in much nearer relations with one another than men do, in consequence of the onesided nature of their calling. This makes them endeavour to lay stress upon differences of rank.

"It is only the man whose intellect is clouded by his impulses that could give the name of the fair sex The unæsthetic to that undersized, narrow-shouldered, sex.

broad-hipped, and short-legged race, for the whole beauty of the sex is bound up with the sex-impulse. Instead of calling them beautiful, there would be more warrant for describing women as the unæsthetic sex. Neither for music, nor for poetry, 
nor for fine art, have they really and truly any sense or perceptibility; it is mere mockery if they make a pretence of it in order to assist their endeavour to please. Hence as a result of this they are incapable of taking a purely objective interest in anything, and the reason of it seems to me to be as follows: A man tries to acquire direct mastery over things, either by understanding them or by forcing them to do his will. But a woman is always and everywhere reduced to obtaining this mastery indirectly - namely, through a man-and whatever direct mastery she may have is entirely confined to him. And so it lies in a woman's nature to look upon everything only as a means for conquering man; and if she takes an interest in anything else it is simulated-a mere roundabout way of gaining her ends by coquetry and feigning what she does not feel. Hence even Rousseau declared: 'Women have in general no love for any art; they have no proper knowledge of any, and they have no genius.' "No one," Schopenhauer continues, "who sees at all below the surface can have failed to remark the same thing. You need only observe the kind of attention women bestow upon a concert, an opera, or a play-the childish simplicity, for example, with which they keep on chattering during the finest passages in the greatest masterpieces. If it is true that the Greeks excluded women from their theatres, they were quite right in what they did; at any rate, you would have been able to hear what they said upon the stage. In our day, besides, or in lieu of saying, 'Let a woman keep silence in the church,' it would be much to the point to say, 'Let a woman keep silence in a theatre.' This might, perhaps,

No mastery of art. be put up in big letters on the curtain." In art or letters women have not produced a single great work. Many women show a mastery of technique in art, but never of art. 
"The case," says Schopenhauer, "is not altered by particular and partial exceptions; taken as a whole, women are, and remain, thoroughgoing Philistinism of women.

Philistines, and quite incurable. Hence, with that absurd arrangement which allows them to share the rank and title of their husbands, they are a constant stimulus to his ignoble ambitions. And, further, it is just because they are Philistines that modern society, where they take the lead and set the tone, is in such a bad way. Napoleon's saying, that women have no rank, should be adopted as the right standpoint in determining their position in society; and as regards their other qualities, Chamfort makes the very true remark, "They are made to trade with our own weaknesses and our follies, but not with our reason.' The sympathies that exist between them and men are skin-deep only, and do not touch the mind, or the feelings, or the character. They form the sexus sequior - the second sex, inferior in every respect to the first; their infirmities should be treated with consideration; but to show them great reverence is extremely ridiculous and The sexes unequal.

lowers us in their eyes. When $\mathrm{Na}$ ture made two divisions of the human race, she did not draw the line exactly through the middle. These divisions are polar and opposed to each other, it is true, but the difference between them is not qualitative merely, it is also quanti- tative.

"This is just the view which the ancients took of woman, and the view which the people in the East take now; and their judgment as to her proper position is much more correct than ours, with our old French notions of gallantry and our preposterous system of reverence-that highest product of Teutonico-Christian stupidity. These notions have served only to make 
women more arrogant and overbearing; so that one is occasionally reminded of the holy apes in Benares, who, in the consciousness of their sanctity and inviolable position, think that they can do exactly as they please.

"But in the West the woman, and especially the lady, finds herself in a false position; for woman is by

Woman in European society.

no means fit to be the object of our honour and veneration, or to hold her head higher than man and be on equal terms with him. It would be a very desirable thing if this 'number two' of the human race were in Europe also relegated to her natural place, and an end put to that lady-nuisance, which not only moves all Asia to laughter, but would have been ridiculed by Greece and Rome as well. It is impossible to calculate the good effect which such a change would bring about in our social, civil, and political arrangements. There will be no necessity for the Salic law; it would be a superfluous truism. In Europe, the lady, strictly so called, is a The lady.

being who should not exist at all; she should be either a housewife or a girl who hoped to become one; and she should be brought up not to be arrogant, but to be thrifty and submissive. It is just because there are such people as ladies in Europe that the women of the lower classes-that is to say, the great majority of the sex-are much more unhappy than they are in the East. And even Lord Byron says: "Thought of the state of women under the ancient Greeks-convenient enough. Present state a remnant of the barbarism of the chivalric and the feudal ages-artificial and unnatural. They ought to mind home, and be well fed and clothed, but not mixed in society. Well educated, too, in religion, but to read neither poetry nor politics, nothing but books of piety 
and cookery. Music, drawing, dancing, also a little gardening and ploughing now and then. I have seen them mending the roads in Epirus with great success. Why not, as well as haymaking and milking?"'

The Western laws of marriage which make the woman equivalent to man are all wrong, according to Schopenhauer. There is no such equality. If such

The laws of marriage. must be, shrewd men will of ten scruple to make the sacrifice. These marriage laws drive men from marriage. This causes the increase of the unhappy class of old maids, and that of the joyless "daughters of joy." For these reasons, Schopenhauer finds a logical religion in Mormonism, by which, in theory at least, both these classes are obliterated. The unnatural rights of women bring unnatural duties. They are forced to do things which they can not do well, a prolific source of evil.

The problem of society is, then, the recognition and regulation of polygamy. By this means woman will be reduced to "her true and natural position as a subordinate being, and the lady-that monster of European civilization and Teutonico-Christian stupidity-will disappear from the world, leaving only women, but no more unhappy women of whom Europe is now full."

The love women have for children is instinctive, not rational. It is therefore no evidence of strength of mind or morals.

"Women should not inherit or control anything. Their vanity shows itself only in love of show and finery. With man the natural source of pride is intellect, learning, courage.

"If the prominence of woman is due to the downfall of Sparta and France, to the baneful institution of the lady the downfall of modern Europe may be ascribed. 
"However that may be, the false position which women occupy, demonstrated as it is in the most glaring Dependence of woman.

way by the institution of the lady, is a fundamental defect in our social scheme, and this defect, proceeding from the very heart of it, must spread its baneful influence in all directions.

"That woman is by nature meant to obey may be seen by the fact that every woman who is placed in the unnatural position of complete independence, immediately attaches herself to some man, by whom she allows herself to be guided and ruled. It is because she needs a lord and master. If she is young, it will be a lover; if she is old, a priest." *

Such, in brief, is the indictment Pessimism brings against woman. We may eliminate from it the weak discussion of marriage, and the childish impotence of

* In a similar vein are the following words, which Mr. Harold Frederic puts into the mouth of his cynical Dr. Ledsmar:

"Our boys, for instance, traverse in their younger years all the stages of the childhood of the race. They have terrifying dreams of awful monsters and giant animals of which they have never so much as heard in their waking hours; they pass through the lust for digging caves, building fires, sleeping out in the woods, hunting with bows and arrows-all remote and ancestral impulses; they play games with stones, marbles, and so on, at regular stated periods of the year which they instinctively know, just as they were played in the bronze age, and Heaven only knows how much earlier. But the boy goes through all this, and leaves it behind him-so completely that the grown man feels himself more a stranger among boys of his own place who are thinking and doing precisely the things he thought and did a few years before, than he would among the Kurds or Eskimos. But the woman is totally different. She is infinitely more precocious as a girl. At an age when her slow brother is still stubbing along somewhere in the Neolithic period, she has flown away ahead to a kind of mediæval stage, or dawn of mediævalism, 
the lines of action which Schopenhauer suggests. The social problem of any society worthy to be called civilized will not be solved by the regulation of polygamy nor by the perpetuation of masculine selfishness.

We may note, too, that the "lady-nuisance" which distresses the philosopher is only a phase of the "lord-

"The lordnuisance." nuisance" which has temporarily stood in the way of the progress of European democracy. If the "lady-nuisance" is ridiculous to-day, the "lord-nuisance" will be equally absurd to-morrow. Pomp and fatuity know no sex. The dry rot of life without effort affects men and women alike. Schopenhauer's attitude throughout the discussion of woman is that of a blasé collector discussing his neighbour's bric-a-brac. He finds it out of taste and out of harmony-not worth half it cost. But it is none of his business, and he has no responsibility for it.

But, waiving all minor criticisms, we find in this harsh review many elements of truth.

It is an expression of the results of an attempt to "see things as they really are." But to see things in Blindness of pessimism.

such fashion is not to see the whole truth. The greatest truth lies in what shall be, in the flow of the underlying stream of tendencies. Why are things as they are? From what condition have they come, and what is the movement of the forces which govern future conditions?

If the work and the life of woman seem less important than those of man, it is because we measure them

which is peculiarly her own. Having got there, she stays there; she dies there. The boy passes her as the tortoise did the hare. He goes on, if he is a philosopher, and lets her remain in the dark ages, where she belongs. If he happens to be a fool, which is customary, he stops and hangs around in her vicinity." (Damnation of Theron Ware, p. 324.) 
from a man's standpoint, not from that of humanity. From the standpoint of the race, the sexes can not be

Woman from man's standpoint. unequal. The one sex balances the other. The line in the long run must be drawn evenly and equally. If in any race of people the woman does not do her share of the life work, the process of natural selection sets this race aside in favour of some one more normally constituted.

As road menders, soldiers, workmen, we may admit the inferiority of woman. I have seen women har-

Unnatural competition. nessed with dogs in Holland, drawing through the canals a vessel on which

a man sits to steer. It is said in Italy that "women are better than dogs for carrying burdens, but not so good as mules." This may be, but it is not well for Italy that its women are brought into competition with its mules.

"You can get more in your market for a quart of milk than a quart of blood," says Thoreau, "but yours is not the market heroes carry their blood to." Nor should womanhood be forced to compete in a market which values only physical strength. But this labour market of Italy or Holland does not represent the permanent relations of life. The work of the woman lies primarily with the young. In the nursery and the schools of to-day the history of to-morrow is written. Doubtless the investigations of man, his ingenuity, and his force have been tremendous factors in the history of civilization. It is not necessary to belittle them to recognise the helpfulness of woman. The making of men is the woman's part. The home and the schools are as large a factor in human progress as the railway and the telegraph. The work of woman looks forward to the future. As her work is important so is her edu- 
cation vital. Folly and weakness are as harmful in the home as in the state. That which is to-day in the home to-morrow will be in the state. The wise woman, mother of wise men, may not be seen of the world, but her influence for good is none the less potent.

Where the home is not sound the state is insecure. The coming man must spring from the home. The

Evolution of the home. child of a homeless race can not compete with him. There is no factor in evolution more sure to survive in life struggles than the instinct to care for the young. Altruism prevails because it is useful, and this form of altruism is potent above all else. Care for the young makes the home. It binds the parents together. It ennobles the sex relation and makes its impulses worthy the name of love. John Fiske has maintained that the prolonged infancy of man was the primary factor in his separation as a higher type from the brute creation. This prolonged infancy demanded a mother's care and a father's support. In these arose the home. Even in nomadic life the family kept together, and the relations of the food-winning father and the protecting mother were equal in value from the standpoint of race evolution. From the home the school is a natural extension. It is a further prolongation of infancy with a view to a higher ultimate development.

But all this food-winning and child-helping is a burden to the individual. The wise man, Schopenhauer Freedom of man. tells us, hesitates to sacrifice his freedom in equal union with woman. His freedom for what? Who is he that he should be so occupied with his own affairs? Is it pleasure that he seeks-pleasure for pleasure's sake? art for art's sake? rest for rest's sake? In the process of evolution there will be no place for him. Nature asks her 
creatures to busy themselves along lines that are helpful to others. The child of altruism survives. When the drone bee-the male-has accomplished his purpose, he is ruthlessly stung to death by the workers. He is no longer needed in the community. That he would live for life's sake, that he would buzz for buzz's sake, does not concern the workers. $\mathrm{He}$ is of no use to the future -therefore away with him!

Let us for present purposes accept Schopenhauer's analysis of the defects of woman's character. May we Each defect a historic cause. not say that for each real defect there is a historic cause? To remove the wrong is to destroy its reaction. If women are given to small deceit, it is because men have been addicted to small tyranny. If women are short-sighted, it is because in the nature of things the near things have been woman's province. If a woman has not a judicial mind, it is because the protection of the child makes her necessarily a partisan. If woman in her care of the species neglects the individual, it is because in the past she has been driven or sold into the custody of individuals not lovable for themselves. If she shows in one form or another the same weaknesses as man, it is because she is, in fact, very man, bone of his bone and flesh of his flesh. We are all poor creatures, and to quarrel with the defects of human nature is as futile as to hold "a feud with the equator." The desire of woman to seek mastery through the conquest of man is in part an outgrowth of the militarism of past generations, when security was possible only through such means. It is a trait of the lower races of men, as of the monkey families, that the male should be a tyrant. Whenever tyranny exists it is met by deceit. In the reign of physical force, those who are weak must win strength by the force of love or intrigue. This condi- 
tion is not confined to woman. Those men who were favourites of princes used the same methods of conForce breeds deceit.

quest. Moreover, the power of a strong will over a weak one has always been a factor in history, even though the strong will be in a weak body. The freedom of man has brought with it the freedom of woman. With woman as with man not all are ready to be free. The fool when free shows his folly. It is safer for him to follow his class, to govern his life by tried conventionality, rather than by imperfect reason. The emancipation of woman permits the growth of senseless fads and meaningless superstitions, distorted desires and hysterical impulses. But the emancipation of man has had just the same effect. In the long run all these things are outworn; the survival of the fittest is the survival of the wise.

The offensive phases of "new womanhood" are temporary and self-curative. They are of the nature of fads which encumber and disguise real progress. The woman of the future will be the fit and equal partner of the future man. As the wise and the strong will prize the womanly virtues, so will she be modest, sympathetic, and beautiful. Nevertheless she need not lack a degree of sturdy strength, without which motherhood fails of its best fulfilment. Yet in so far as the highest physical activity and its coordinate reasoning power are not to be demanded of women in general, so in the nature of things must the brain and muscle of woman retain qualities of immaturity. The accelerated development of these qualities in the male of a race "sore bestead by the environment," must leave the female relatively undeveloped if judged by the standard of the man.

But, judged by the standard of womanhood, man shows an equal number of crude instincts and embry- 
onic traits. In the division of labour this is necessarily the case. If it were not, there would need be no division of sex, and womanhood and manhood would be identical.

". . : Could we make her as the man, Sweet love were slain. His dearest bond is this, Not like to like, but like to difference."

When woman has perfect freedom of choice in marriage, there will be more love in the world than now.

The equal marriage. Too many women now marry under duress. Money or title, or place or security, are not valid reasons for marriage. The chances are that a union on such a basis will never prove a marriage at all. Nor is it right that marriage should rest on mere propinquity. The choice of the nearest scarcely rises above the automatic loves of the lower animals.

In the conditions arising from an expanding civilization, the art of being a woman becomes a difficult one. Being a woman. It is unsafe on the one hand not to take part in industrial or intellectual activities. On the other hand, to be absorbed in these matters may be to lose sight of the more important functions which must belong to woman in any condition of social development. "Woe to the land that works its women!" says Laurence Grönland. But there is equal woe to the land in which women find nothing to do. On the human side idleness and inertia are just as destructive to women as to men. Brain and muscles must be used each in its way, and the penalties for disuse are stagnation, ennui, and misery. It is not every woman, as matters are, who can find occupation in household cares and in the training of children. To the extent that women are not so occupied their need of thought and action is not essentially different from that of men. 
A woman, like a man, must find something to do if she is to avoid misery and decay. Her release from the industrial world is conditional on the Release from labour, not idleness. fact that she has something better to do than to win food; something more vital to social development than to add to the physical resources of life. So long as society exists, the "eternal womanly" will find its own sphere of full activity. In the long run that division of labour will prove best which justifies itself by enduring. 


\section{XIV.}

\section{THE STABILITY OF TRUTH.}

"Grau, theurer Freund, ist alle Theorie, Und grün des Lebens goldner Baum."-Goethe.

Within the last few years three notable assaults have been made on the integrity of science. Two of these have come from the hostile camp Assaults on the integrity of science. of mediæval metaphysics, the other from the very front of the army of science itself. Salisbury, Balfour, and Haeckel agree in this, that "belief " may rest on foundations unknown to "knowledge," and that the conclusions of science may be subject to additions and revisions in accordance with the demands of "belief." To some considerations suggested in part by Balfour's Foundations of Belief and Haeckel's Confession of Faith of a Man of Science, I invite attention in the present paper.

The growing complexity of civilized life demands constantly more knowledge as to our material surround-

The secret of power. ings and greater precision in our recognition of the invisible forces or tendencies about us. We are in the hands of the Fates, and the greater our activities the more evident become these limiting conditions. The secret of man's power is to know his limitations. To this end we need constantly new accessions of truth as to the universe and better definition of the truths which are old. 
Such knowledge, tested and placed in order, we call science. Science is no longer individual. It is the gathered wisdom of the race. Only a part of it can be grasped by any one man. Each must enter into the work of others. Science is the flower of the altruism of the ages, by which nothing that lives "liveth for itself alone." The recognition of facts and laws is the province of science. We only know what lies about us from our own experience and that of others, this experience of others being translated into terms of our own experience and more or less perfectly blended with it. We can find the meaning of phenomena only from our reasoning based on these experiences. All knowledge we can attain or hope to attain, in so far as it is knowledge at all, must be stated in terms of human experience. The laws of Nature are not the products of science. They are the human glimpses of that which is the "law before all time."

Thus human experience is the foundation of all knowledge. Even innate ideas, if such

Human experience the basis of human knowledge. ideas exist, are derived in some way from knowledge possessed by our ancestors, as innate impulses to action are related to ancestral needs for action.

But is human experience the basis also of belief as it is of knowledge?

This raises the further question, Is "to believe" more than "to know"? Shall a sane man extend belief Knowledge and belief. in directions where he has no knowledge and in lines outside the bounds of his power to act? Can Belief soar in space not traversable by "organized common sense"? If such distinction is made between "knowing" and "believing," which of the two has precedence as a guide for action? Is belief to be tested by science? Or is 
science useful only where belief is indifferent to the subject-matter? If belief is subordinate to the tests of science, to be accepted or rejected in the degree of its accord with human experience, then it is simply an annex to science, a footnote to human experience, and the authority of the latter is supreme. If, however, truth comes to us from sources outside of human experience it must come in some pure form, free from human errors. As such it must claim the first place. In this event the progress of science will be always on a lower plane than the progress of belief.

In a recent address before the British Association for the Advancement of Science, the Marquis of Salisbury

Views of the Marquis of Salisbury. made in brief this contention: The central thought of modern science is evolution, the change from the simple to the complex. This implies, in his judgment, not only the fundamental unity of all life, but the fundamental unity of all matter, and perhaps of all force as well. In spite of the claims of scientific men even the fact of organic evolution is far from demonstrated; while of inorganic evolution, the development of the chemical elements, science can tell us nothing. Wherefore the marquis, in view of the failure of science to keep up with the progress of belief, grows jocose and patronizing. His advice to his scientific associates might be stated in the words of Thackeray, that "we should think small beer of ourselves and pass around the bottle."

More recently another British statesman, Mr. Arthur J. Balfour, has discussed the Foundations of Belief. He contends that the methods of science can Views of Arthur J. Balfour. not give us absolute truth. Its methods are "of the earth, earthy." Its claim of trust in the infallibility of its own processes has no 
higher authority than the claim of infallibility made at times by certain religious organizations; for, as only the senses and the reason can be appealed to in support of the claims of the senses and the reason, the argument of science is of necessity reasoning in a circle. Science can give us no ground solid enough to bear the weight of belief. Belief must exist, and it may therefore rest on the innate needs of man and the philosophy which is built on these needs in accordance with the authority which the human soul finds sufficient.

Balfour calls attention to the fact that human experience is not in its essence objective. It consists only of varying phases of consciousness.

Human experience not objective.
These phases of consciousness at best only point toward truth. They are not truth itself. They vary with the varying nerve cells of each individual creature on whom phases of consciousness are impressed, and again with the changes in the cells themselves. The tricks of the senses are well known in psychology, as is also the failure of the senses as to material outside their usual range. Life is at best "in a dimly lighted room," and all the objects about us are in their essence quite different from what they seem. This essence is unknown and unknowable. We are well aware that we have no power to recognise all phases of reality. The electric condition of an object may be as real as its colour or its temperature, and yet none of our senses respond to it. Our eyes give but an octave of the vibrations we call light, and our ears are dull to all but a narrow range in pitch of sound.

Likewise is reason to be discredited. The commonest things become unknown or impossible when viewed "in the critical light of philosophy." Balfour shows that the simple affirmation "the sun gives light," loses 
all its meaning and possibility when taken out of the category of human experience and discussed in terms of

Ineffectiveness of reason. philosophy. In like manner can any simple fact be made to appear as myth or dream. A man can be brought to doubt the existence of himself or of any object about him. For instance, take the discussion of "John's John" and of "Thomas's John," as given by Dr. Holmes. Is the real John the John he appears to John himself? Or is he real only in the form in which Thomas regards him, or as he looks to Richard and Henry, whose interest in him is progressively less? All that we know of the external universe is derived from impressions made directly or indirectly on our nervous systems and from recorded impressions made on the systems of others: and a part of this external universe we ourselves are. All that we know even of ourselves is that which is external to ourselves. Thus, with all this, each man forms in his mind a universe of his own. "My mind to me a kingdom is," and this kingdom in all its parts is somewhat different from any other mental kingdom. It is continually changing. It was made but once and will never be duplicated. When my vital processes cease, this kingdom will vanish " like the baseless fabric of a vision, leaving not a wreck behind." Our mind is of the "stuff that dreams are made of"; and our bodies-what are they? Physically each man is an alliance of animals, each one of a single cell, each cell with its processes of life, growth, death, and reproduction, each one with its own "cell-soul" which presides over these processes. In the alliance of these cells, forming tissues and organs, we have the phenomena of mutual help and mutual dependence. In man we find the phenomena of animal life on a larger and more differentiated scale than in the lower forms, but to em- 
phasize this in its details obscures the fact of self. What is the vital force which holds these alliances together, and is it after all more than another name for the movement of molecules? And of what are our cells composed? Carbon, oxygen, hydrogen, nitrogen, we know, by name; but what are these in essence, and how are they different one from another? Does matter really exist? Mathematicians have claimed that all re-

The nature of self.

lations of ponderable matter and force might hold if the atoms of matter were not realities, but simply relations. Each of these atoms possessed of attraction or weight may be a vortex ring or eddy in the ether, of which the ultimate units have vibration but not attraction. If, therefore, the body of man be an alliance of millions of animal cells, each cell formed of millions of eddies in an inconceivable and impossible ether; if all things around us are recognised only by their effect on the most unstable part of this unstable structure, then again "let us think small beer of ourselves and pass around the bottle."

But, again, we must remember that the conclusions of science represent human experience. Each fact or law must be expressed in terms of genIn terms of hu- eralized human experience, if it is exman experience.

pressed or made intelligible at all. To such terms the word reality applies, and beyond such reality we have never gone. Apparently beyond it we can not go, at least in the only life we have ever known. Balfour's plea for "philosophic doubt" of the reality of the subject-matter of science is simply a rhetorical trick of describing the known in terms of the unknown. By the same process we may call a fishwife an "abracadabra " or an "icosahedron," and by the same process we can build out of the commonest materials "an occult 
science" or a new "theosophy." The "measure of a man" is the basis of human knowledge, and whatever can not be brought to this measure is The measure of a man. no part of knowledge. In converse fashion Balfour speaks of the unknown in terms of the known, of the infinite in terms of human experience. This gives to his positive "foundations of belief " an appearance of reality as fallacious as the unreality he assigns to the foundations of science. This appearance of reality is the base of Haeckel's sneer at the current conception of the Divine Being as a "gaseous vertebrate."

It is perfectly easy for science to distinguish between subjective and objective nerve conditions. It Nature of sanity.

can separate those produced by subjective nervous derangements, or by conditions already passed, from those which are contemporaneous impressions of external things. It is perfectly easy for common sense to do the same. To be able to do so is the essence of sanity. The test of sanity is its liveableness, for insanity is death. The "borderland of spirit," of which we hear so much of late-the land where subjective and objective creations jostle each other at will-is the borderland of death. The continued existence of animals and men is based on the adequacy of their sensations and the veracity of their actions. The existence of any creature is in general proof of the sanity of its ancestry, or at least of the sanity of those who controlled the actions of its ancestors.

This veracity is gauged by the degree of coincidence of subjective impressions and objective truth. He who makes a fool's paradise or a fool's hell of the world about him is not allowed to live in it. This fact in all its bearings must stand as a proof that the universe is 
outside of man and not within him. In this objective universe which lies outside ourselves we find "the ceaseless flow of force and the rational intelligence that per-

The infinite understanding. vades it." No part of it can be fully understood by us, but in it we find no chance movement, "no variableness nor shadow of turning." That such a universe exists seems to demand some intelligence capable of understanding it, of stating its properties in terms of absolute truth, as distinguished from those of human experience. Only an Infinite Being can be conceived as doing this, hence such knowledge must enter into our conception of the Infinite Being, whatever may be our theology in other respects; for, to know any object or phenomenon in its fulness, "all in all," "we should know what God is and man is."

It is therefore no reproach to human science that it deals with human relations, not with absolute truths. "The ultimate truths of science," Dr. Schurman has said, "rest on the same basis as the ultimate truths of philosophy"-that is, on a basis that transcends human experience. This is true, for science has no "ultimate truths." There are none known to man. "The perfect truth," says Lessing, "is but for Thee alone." With ultimate truths human philosophy tries in some fashion to deal. To look at the universe in some degree through the eyes of God is the aim of philosophy. In its aim it is most noble. Its efforts are a source of strength in the conduct of human life. But its conclusions are not truth. They range from the puerile to the incomprehensible, and only science, that is, "common sense," can distinguish the two. For this reason, just in proportion as philosophy is successful, it is unfit to serve as a basis of human action. Human knowledge and action have human limitations. The 
chief of these is that whatever can not be stated in terms of human experience is unintelligible to man. Whatever can not be thought can not be lived.

Philosophy has its recognised methods of procedure. These are laid down in the mechanism of the human The test of truth. brain itself. Science has found these methods untrustworthy as a means of reaching objective truth. The final test of truth is this : "Can we make it work? Can we trust our lives to it?" This test the conclusions of philosophy can not meet. In so far as they do so they are conclusions of science. As science advances in any field, philosophy is driven out of it. The fact has been often noted, that every great conclusion of science has been anticipated by philosophy, most of them by the philosophy of the Greeks. But every theory science has shown to be false has been likewise anticipated. The Greeks taught the theory of development centuries before Darwin. But if Darwin's studies in life variation had led to any other result whatsoever, he would have been equally anticipated by the Greeks. In other words, every conceivable guess as to the origin and meaning of familiar phenomena has been exhausted by philosophy. Some of these guesses contain elements of truth. Which of these has such elements it is the business of science to find out. Philosophy has no means of doing so. A truth not yet shown to be true is in science not a truth. It has no more validity than any other generalization not shown to be false. HelmThe matter phi- holtz tells us that philosophy deals with losophy deals with. such "schlechtes Stoff," such bad subjectmatter, that it can give no trustworthy conclusions. Science alone can give the test of human life. The essence of this test is experiment. The tests of philosophy are mainly these: "Is the conception 
plausible? Has it logical continuity? Is it satisfying to the human heart?" And in this connection the figurative word "heart" is best left undefined. In other words, the sources and tests of philosophy are alike subjective, intellectual or emotional. If we take from philosophy the "heart" element, the personal equation, it becomes logic or mathematics. Mathematics is metaphysics working through methods of precision. It is a most valuable instrument for the study of the relations and ramifications of knowledge, but it can give no addition to knowledge itself. Dr. William James defines metaphysics as "the persistent attempt to think clearly." This definition is good so far as it goes, but to think clearly is a function of science also. Metaphysics is rather the "attempt to think clearly" in fields where exact data are unattained or unattainable.

For example, the claim is made in the name of evolutionary philosophy that all matter is one in essence, Protyl. therefore all the chemical elements, some seventy in number, must be the same in substance. In this case all must be derived from the same primitive stuff, and the hypothetical basis of all ponderable matter has been called protyl. As a working theory this is most ingenious. But is it science? Is it worthy of belief ? Certainly science knows nothing as yet of the identity of these elements. In a general way science is finding out that the processes of Nature are more complex than man had supposed, while the elements on which these processes rest, matter and force, are more simple. How far can this generalization go ? To every test human experience has devised each chemical element remains the same, its atoms unchangeable as well as indestructible. Therefore to speak of them as forms of one substance is to go beyond knowledge. Science does not teach this. But to phi- 
losophy this offers no difficulty. It is still plausible to suppose that by some combinations of primitive units these variant atoms are formed. Such an idea would have logical continuity, and as we are becoming used to notions of primal unity, we find such an idea satisfying to our consciousness. If this be true, somewhere, somehow, lead will be resolved into its primal elements, and these elements may be reunited in the form of gold. Then will the dream of the alchemist become fact; but not until then-which is a matter of the greatest importance. Such transmutation is as yet no part of knowledge. We certainly do not know that lead can be changed into that which is transmutable into gold. We do not know it, I say; but may we believe it? Is the foundation of belief less secure than that of knowledge? Can we trust philosophy to tell us what to believe, while we must look to science to tell us what we know ?

This brings us to the question of definitions. If knowledge and belief are of like rank, both must rest on science, and the results of philosophy must come to science only as hints or suggestions as to future lines of research.

If knowledge implies stability, and belief does not, the relation of the two is also clear. In that case belief would be a word of light meaning, expressive of whim or of the balance of probabilities in association with prejudice. Belief would then be the pretense of knowledge, as compared with knowledge itself. Along its paths life can not march with courage and effectiveness. It is not for such beliefs as this that the martyrs lived or died. Their inspiration was the positive belief of science, or the negative belief of the falsity of the ideas tyranny or superstition had forced upon them.

To avoid a discussion foreign to my purpose, I wish, if possible, to separate the word "belief," as used in this 
paper, from the word "religion." The essence of "belief " is the categorical statement of propositions. These may be built into a creed, which word is the Latin synonym of " belief.".

"Religion" implies rather a condition of the mind and heart, an attitude, not a formula. Faith, hope, Religion and belief. charity do not rest on logic or observation. Religion implies a reverent attitude toward the universe and its forces-a tender feeling toward one's fellow-mortals. "Pure religion and undefiled" has never formulated a "creed," has never claimed for itself orthodoxy. It has no stated ritual and no recognised cult of priests. Much that passes conventionally as religious belief among men has no such quality or value. It is simply the débris of our grandfathers' science. While religion and belief become entangled in the human mind, so as not to be easily separable, the one is not necessarily a product of the other.

Most that is considered vital in religious belief does not involve objective propositions. It is rather associated with personal character or temperament, and its generalizations must be expressed in terms more or less metaphorical or poetical, for their origin is largely subjective, and no terms of purely human experience are adequate for their definition. Such, for example, is the statement of belief that "the heart of the universe is sound," that "God is Love," that "Love is the greatest thing in the world," or that "there is a force outside ourselves that makes for righteousness." Such expressions imply the perfect harmony of natural laws. Such laws-as Agassiz has expressed it-are "the thoughts or operations of the highest powers in the universethe highest Something, however we may choose to regard it." With belief of this sort science has no quarrel, 
for these broad statements of personal faith yield no deductions which conflict with objective facts of experience.

As the third of these efforts to discredit science and its methods I have placed Professor Haeckel's recent Haeckel's Confession of Faith. address, The Confession of Faith of a Man of Science. This remarkable work is an eloquent plea for the acceptance of the philosophic doctrine of monism as the fundamental basis of science. This doctrine once adopted, we have the groundwork for large deductions which forestall the slow conclusions of science; for monism necessitates belief in certain scientific hypotheses resting as yet on no foundation in human experience, incapable as yet of Monism. scientific verification, but which are a necessary part of the monistic creed. The primal conception of monism is that there lives one spirit in all things, and that the whole cognizable world is constituted and has been developed in accordance with one common, fundamental law. This involves the essential oneness of all things, matter and force, object and spirit, Nature and God. This philosophical conception of monism and pantheism can not be made intelligible to us, because it can be stated in no terms of human experience. But it has certain necessary derivatives, according to Haeckel, and these are intelligible because their subject-matter is available for scientific experiment.

First among these postulates, called by Haeckel " articles of faith," comes " the essential unity of organic and inorganic Nature, the former having Unity of organic been evolved from the latter only at a and inorganic Nature. relatively recent period." This involves the "spontaneous generation" of life from inorganic matter. It also resolves " the vital force," or the force which appears in connection with protoplas- 
mic structures, into properties shown by certain carbon compounds under certain conditions. Life is thus in a sense an emanation of carbon, "the true maker of life," according to Haeckel, "being the tetraëdral carbon molecule."

This "article of faith" implies also the unity of the chemical elements, each of which is a product of the Unity of chemical elements. evolution of the primal unit of matter and force. Force and matter are likewise one, because neither appears except in the presence of the other. The inheritance of acquired characters is also made a corollary of monistic belief.

Now all these hypotheses are possibly true, but none of them are as yet conclusions of science. They meet the conditions required by philosophy. Monism not science. They are plausible. They have the merit of logical continuity, and, excepting to those persons biased by early subjection to contrary notions, they "satisfy the human heart." There should be no natural repugnance to monism or to pantheism, difficult as it is to associate the idea of truth and reality with either, or with the opposite of either. Speaking for myself, I feel no prejudice against them. They lend themselves to poetry; they appeal to the human heart. In Haeckel's own words, referring to something else: "Such hereditary articles of faith take root all the more firmly the further they are removed from a rational knowledge of Nature, and enveloped in the mysterious mantle of mythological poesy." The present resistance to them may in time be turned into superstitious reverence for them; for, of all the philosophic doctrines brought down as lightning from heaven for the guidance of plodding man, these seem most attractive, and least likely to conflict with the conclusions of science. 
But can we give them belief? Let us pass by the doctrine of monism, with which science can not concern itself. What of the corollaries? SponSpontaneous generation not science. taneous generation, for example, has been the basis of many experiments. Like the transmutation of metals, it seems reasonable to philosophy. The one idea has been the will-o'-the-wisp of biology as the other has of chemistry. We know absolutely nothing of how, if ever, non-life becomes life. So far as we know, generation from first to last has been one unbroken series-all life from life. We have no reason to believe that spontaneous generation exists under any conditions we have ever known. We have likewise reason to believe that if it exists at all we have no way of recognising it. The organisms we know have all had a long history. Even the simplest ever examined shows traces of a long ancestry, a long process of natural selection, and of many concessions to environment. We know of no life that does not show such concessions. We know no creature that does not show homologies with all other living beings whatsoever. So far as this fact goes, it tends to show that all life comes from one common stock, a single generation or creation. If this be true, spontaneous generation, whatever it may be, is not a phenomenon of frequent occurrence.

If life does now appear without living parentage, if organisms fresh from the mint of creation are now developed from inorganic matter, they are so simple that we can not know them. They are so small that we can not find them. They would be made, we may suppose, each of a small number of molecules. If there is truth in the calculations of Lord Kelvin and others, that a molecule in a drop of water is as small as a marble in comparison with the earth, then we may not look for these creatures. 
If we can not find them, we do not know that they exist. If we do not know that they exist, shall we believe that they do? Is it not better, as Emerson suggests, that men should not " pretend to know and believe what they do not really know and believe" ?

It may be that the present existence of life in a world once lifeless renders spontaneous generation a "logical necessity." But the "logical necessity" exists in our minds, not in Nature. Science knows no "logical necessity," for the simple reason that we are never able to compass all the possibilities in any given case.

If we are to apply philosophic tests to the theories of reincarnation, we may find them equally eligible as Reincarnation. articles of belief. They are plausible, to some minds at least; they have logical continuity. They are satisfying to the human heart; at least this is claimed by their advocates. Their chief fault is that science knows nothing of them, and her inductions yield them no support. In other words, their only reality is that of the visions of dreamland. From the objective side their postulates and arguments have no existence. The whole thing is meaningless. If plausibility and acceptability serve as sufficient foundations for belief, then belief itself is a frail and transient thing, no more worthy of respect than prejudice, from which, indeed, it can not be distinguished.

Haeckel recognises this difference clearly enough by using the term belief for "hypotheses or conjectures of Haeckel's defini- more or less probability" by which "the tion of belief.

gaps empirical investigation must leave in science are filled up." "These," he says, "we can not indeed for a time establish on a secure basis, and yet we may make use of them in the way of explaining phenomena, in so far as they are not incon- 
sistent with a rational knowledge of Nature." "Such rational hypotheses," he says, "are scientific articles of faith." It is not clear, however, that so large a name as faith need be taken for working hypotheses confessedly uncertain or transient. The words "make-believe," used by Huxley in some such connection, might well be applied to hypothetical "articles of faith" which have no basis in scientific induction. But it seems to me that it is not necessary for the man of science to say "I believe" in addition to "I know." He should not "believe" where he can not trust. He should put off the livery of science when he enters the service of the Delphian oracles.

That all the doctrines above mentioned are necessarily included in monism, may perhaps be doubted. Monism would probably still flourish were all these theories disproved; for human philosophies have wonderful recuperative power. Their basis is in the structure of the brain itself, and external phenomena are only accessory to them.

If monism is a purely philosophic conception, it can have no necessary axioms or corollaries, except such as are involved in its definition. These could not be scientific in their character, because they could in no way come into relation with the realities of human life. If, however, monism be a generalization, resting in part on human experience, then it must be tested by the methods of science. Until it is so tested, however plausible it may seem, it has no working value. There is no gain

The inheritance of acquired characters. in giving it belief or in calling it truth. Still less should we stultify ourselves by pinning our faith to its postulates as to matters yet to be decided by experiment and to be settled by human experiment only. Haeckel says, for example: "The inheritance of characters ac- 
quired during the life of the individual is an indispensable axiom of the monistic doctrine of evolution. Those who with Weismann and Galton deny this, entirely exclude thereby the possibility of any formative influence of the outer world upon organic form." Here we may ask: Who knows that there is any such formative influence? What do we know of this or any other subject beyond what in our investigations we find to be true? When was monism a subject of special revelation, and with what credentials does it come, that one of the greatest controversies in modern science should be settled by its simple word?

The great bulk of the arguments in favour of the heredity of acquired characters, as well as most of those in favour of the opposed dogma of the unchanged continuity of the germ plasm, are based on some supposed logical necessity of philosophy. All such arguments are valueless in the light of fact. Desmarest's suggestion to the contending advocates of Neptunism and Plutonism was "Go and see." When they had seen the action of water and the action of heat, the contest was over, for argument and contention had vanished in the face of fact. To believe without foundation is to discredit knowledge. Such "confessions of faith" on Haeckel's

The courage of patience. part lead one to doubt whether in his zeal to believe he had ever known what it is to know. Greater than the courage of one's convictions may be the courage of patience where convictions are not yet attainable.

"Science," says Richard T. Colburn, "does not concern itself with teleological suppositions; that is to say, it is reluctant to resort to any of them to explain the observed cosmos, and prefers to listen in neutral attitude to the rival philosophies-theism, manicheism, atheism, monism, spiritism, or materialism-but it is at 
least equally well equipped to pass judgment on such speculations as their advocates."

In other words, if any of these systems of philosophy are to descend from cloudland to be wrought into human action, they must enter the domain of science and submit themselves to scientific tests.

Again, if we are to allow the revision of the generalizations of science by the addition of acceptable but un-

Revision of science by philosophy. verified doctrines, we must allow the right of similar revision by rejection. Mr. Wallace, for example, would be justified in adding to the certainties of organic evolution his idea of the special creation of the mind of man while the body was separately developed under natural law. The old notion of the separate existence of the ego, which plays on the nerve cells of the brain as a musician on the keys of a piano, would still linger in psychology. The astral body would hover on the verge of physiology, and a strong plea would go up for the reality of Santa Claus.

I have a scientific friend who finds it necessary to exclude by force from his biological beliefs all that is unpleasant in the theories of evolution. And he has the same right to do this that Professor Haeckel has to insist that any scientific beliefs, for which science has yet no warrant, are a necessary part of the orthodoxy of science.

For Haeckel is not content to speak for himself, asking tolerance by tolerance toward others. His belief is no idiosyncrasy of his own. He speaks for all. Every honest, intelligent, courageous scientific man, he tells us, so far as he is truthful, competent, and brave, shares the same belief. His confession of faith is nothing if not orthodox. He says :

"This monistic confession has the greater claim to an unprejudiced consideration in that it is shared, I am 
firmly convinced, by at least nine tenths of the men of science now living; indeed, I believe, by all men of science in whom the following four conditions are realized: (I) Sufficient acquaintance with the various departments of natural science, and in particular with the modern doctrine of evolution; (2) sufficient acuteness and clearness of judgment to draw, by induction and deduction, the necessary logical consequences that flow from such empirical knowledge; (3) sufficient moral courage to maintain the monistic knowledge so gained against the attacks of hostile dualistic and pluralistic systems; and (4) sufficient strength of mind to free himself, by sound, independent reasoning, from dominant religious prejudices, and especially from those irrational dogmas which have been firmly lodged in our minds from earliest youth as indisputable revelations."

Against such assumption I must protest. I have nothing against the doctrines save that they are not yet proved true. In themselves, as I have said, they are attractive. One may naturally feel a hopeful interest in wide-reaching theories which seem plausible, but are still unproved or unworkable. This is, however, not "belief." It is rather open-mindedness, open to negative evidence as well as to positive.

As science goes wherever the facts lead, so "science must stop where the facts stop." It can not add to its Science stops where facts stop. methods the running high jump, nor place the divining rod with the microscope, crucible, and calculus among its instruments of precision. Beyond the range of scientific knowledge extend the working and the unworkable hypotheses. Beyond the confines of all these extend the universe of the mind, the boundless realm which is the abode of philosophy. None should better realize these distinctions than men of science. 
The primal motive of science is to regulate the conduct of life. This is in a sense its ultimate end, for it

Primal motive of science. is the first and the last function of the senses and the intellect. If science has any message to man, it is expressed in these words of Huxley: "There can be no alleviation of the sufferings of mankind except in absolute veracity of thought and action and a Message of science. resolute facing of the world as it is." "Still men and nations reap as they have strewn." The history of human thought is filled with the rise of philosophic doctrines, laws, and generalizations not drawn from human experience and not sanctioned by science. The attempt to use these ideas as a basis of human action has been one of the most fruitful sources of human misery.

And now we may turn for a moment to the positive side of scientific belief.

I was walking in the garden, not long ago, with a little girl, to whom I told James Whitcomb Riley's story

Philosophic doubt and common sense. of the "gobelins that get you if you don't watch out "-a story supposed to be peculiarly attractive to children. "But there isn't any such thing as a goblin," said the practical little girl, " and there isn't ever going to be any such thing." Mindful of the arguments of Berkeley and Balfour, I said to her in the spirit of philosophic doubt, "Maybe there isn't any such thing as anything, Barbara?" "Yes, there is," she said, and she looked about her for unquestioned reality; "there is such a thing as anything; there is such a thing as a squash!"

And in this conclusion of the little girl the reality of the objective world, the integrity of science, and the sanity of man are alike bound up. And for its evidence, 
if we are not confined to Balfour's argument in a circle, we must look to the facts of organic evolution, of which the existence of man is a part.

Each living being is a link in a continuous chain of life, going back in the past to the unknown beginnings of life. Into this chain of life, so far as Each organism a link in the chain of life.

we know, death has never entered, because only in life has the ancestor the power of casting off the germ cells by which life is continued. Each individual is in a sense the guardian of the life chain in which it forms a link. Each link is tested as to its fitness to the conditions external to itself in which it carries on its functions. Those creatures unadapted to the environment, whatever it may be, are destroyed, as well as those not adaptable. And this environment by which each is tested is the objective universe. It is not the world as man knows it. It is not the world as the creature may imagine it. It is the world as it is. Nature has no pardon for ignorance or illusions. She is no respecter of persons. Her laws and her penalties consider only what is, and have no dealings with semblances. By this experience we come to know that reality exists, that there

Life deals with realities.

is an external world to the demands of which our senses, our reason, our powers of action are all concessions. The safety of each chain of life is proportioned to the adaptation of its links to these conditions. This adaptation is in its essence obedience. The obedience of any creature is conditioned on its response in action to sensation or knowledge. Sense-perception and intellect alike stand as advisers to its power of choice. The power of choice involves the need to choose right; for wrong choice leads to death. Death ends the chain of which the creature is a link, and the life of the world is continued 
by those whose line of choice has been safe. Death is not the punishment of folly, but its inevitable result. Severity of condition and stress of competition are met in life by the survival of those adequate to meet these conditions. Thus "in creatures sore bestead by the environment," when instinct and impulse fail, reason rises to insure safety. At last with civilized man reason comes to be a chief element in the guidance of life. With greater power to know and hence to choose safely, greater complexity of conditions becomes possible, and the multifarious demands of modern civilization find some at least who can meet them fairly well. To such the stores of human wisdom must be open. To others, safety in new conditions lies only in imitation. The multitudes of civilized men, like the multitudes of animals, are kept alive by the instinct of Conventionality. conventionality. The instinct to follow those who have passed over safely is one of the most useful of all impulses to action. In the same connection we must recognise authority as a Authority.

most important source of knowledge to the individual; but its value is proportioned to the ability of the individual to use. the tests wisdom must apply to the credentials of authority.

But instinct, appetite, impulse, conventionality, and respect for authority all point backward. They are the outcome of past conditions. "New Instinct springs from past conditions. occasions bring new duties," and new facts and laws must be learned if męn prove adequate to the life their own institutions and their own development have brought upon them. To the wise and obedient the most complex life brings no special strain or discomfort. It is as easy to do great things as small, if one only knows how. But to the ignorant, weak, and perverse the growth of civili- 
zation becomes an engine of destruction. The freedom of self-realization involves the freedom of self-perdition. Hence appears the often-discussed relaIntellect points forward. tion of "progress and poverty" in social development. Hence it comes that civilization, of which the essence is mutual help or altruism, seems to become one vast instrument for the killing of fools. In the specialization of life conditions are constantly changing. Every age is an age of transition, and transition brings unrest because it impairs the value of conventionality. With the lowest forms of life there is no safety save in absolute obedience to the laws of the world around them. This obedience becomes automatic and hereditary, because the disobedient leave no chain of descent. All instincts, appetites, impulses to action, even certain forms of illusions, point toward such obedience. Whether we regard these phenomena as variations selected because useful, or as inherited habits, their relation is the same. They survive as guarantees of future obedience because they have enforced obedience in the past. With the most enlightened man, the same necessity for obedience exists, and the instincts, appetites, and impulses of the lower animals remain in him, or disappear only as reason is adequate to take their place. And, in any case, there is no alleviation for the woes of life "save the absolute veracity of action, the resolute facing of the world as it is."

The intense practicality of all this must be recognised. The truths of science are approximate, not ab-

Practicality of sensations. solute. They must be stated in terms of human consciousness, and they can never be dissociated from possible human action. Knowledge which can only accumulate, without being woven into conduct, has never been a boon to its possessor. As food must be formed into tissues, so must 
perception pass over into action. In the lower forms we have the devices, chiefly automatic, by which sensation transmitted to the sensorium reappears as motion. In like manner we find in man, besides these reflex transfers and the reflex connections formed by habit, that science becomes changed to art and knowledge to power. Power and effectiveness are conditioned on accuracy. Every failure in the sense organs, every form of deterioration of the nerves, shows itself in reduction of power. Reduced effectiveness manifests itself through the processes of natural selection as lessened safety of life. Thus the degeneration of the nervous system through excesses, through precocious activity, or through the effect of stimulants, shows itself in untrustworthy perceptions, in uncontrolled muscles, and in general insecurity. Incidentally all these are recorded by fall in social standing. Similar failure follows from any cause impairing the recognition of the reality of external things. The sober mind is necessary to secure life. In

The sober mind. general all civilized men are well born. They come of good stock. For the lineage of perversity, insanity, and even stupidity, is never a long one. The perverse, insane, and the stupid live through the tolerance of others. They can not maintain themselves, and in spite of charity and the sense of conventionality, the mortality caused by the fool-killer is something enormous. It is an essential element in race progress. It grows with increased civilization, because of increasing complexity of condition. It is the chief offset for the systematic life-saving which science makes possible.

The recent "recrudescence of superstition," a striking accompaniment of an age of science, is in a sense dependent on science. Science has made it possible. The traditions of science are so diffused in the community 
at large that fools find it safe to defy them. Those who take dreams for realities; those whose memory impressions and motor dreams are uncontrolled through defective will; those who mistake subjective sensations

The recrudescence of

superstition. produced by disease or disorder for objective conditions-all these sooner or later drop out of existence, taking with them the whole line of their possible successors. The condition of mind which is favourable to mysticism, superstition, and reverie, is unfavorable to life, and the continuance of such condition leads to death. On the billboard across the street (in Oakland, California) I see the advertisement of a lecture on "The Ethical Value of Living in Two Worlds at Once." Whoever thus lives in two worlds is certain soon to prove inadequate for either.

If all men sought healing from the blessed handkerchief of the lunatic, or from contact with old bones or

Life based on dreams and illusions. old clothes; if all physicians used "revealed remedies," or the remedies " $\mathrm{Na}$ ture finds" for each disease; if all business were conducted by faith; if all supposed "natural rights" of man were recognised in legislation, the insecurity of these beliefs would speedily appear. Not only civilization but civilized man himself would vanish from the earth. The safe shelter of the cave and hollow tree would be the cradle of the "new man" and the "new woman." The long and bloody road of progress through fool-killing would for centuries be traversed again. That is strong which endures. Might does not make right, but that which is right will justify itself by becoming might. What we call social virtues are the elements of race stability.

So closely is knowledge linked to action, that in general among animals and men sensation is absent or not 
trustworthy when it can not result in action. Objects too small to be touched are invisible to the eye. Objects beyond our reach, as the stars or the clouds, are not truthfully pictured. Accuracy of percepSensation truth- tion grows less as the square of the disful in the degree tance increases. It is a recognised law possible.

of psychology that only medium variations and differences are correctly estimated. The senses deal correctly only with the near, the mind only with the common. The unfamiliar lends itself readily to illusions. The familiar is recognised chiefly by breaks in continuity. The real forces of Nature are hidden by their grandeur, by their duration. Men see the waves on the surface of the sea, but not the mighty tides that move beneath it. Again, the senses are less acute than the mechanism of sense organs would make possible. This is shown through occasional cases of hyperæsthesia or ultra-sensitiveness. This occurs in abnormal individuals or in diseased conditions. It occurs normally in creatures whose lives in some sense depend on it. Thus some of the most remarkable exhibitions of "mind reading" may be paralleled by retriever dogs, whose reason for existence is found in the hyperæsthesia of the sense of smell. Hyperæsthesia of more than one of the senses would be to most animals a source of confusion and danger rather than of safety. The high development of the brain in man in large degree takes the place of acuteness of special senses. It is part of the function of the will to regulate the senses and to suppress those impressions which should not lead to action.

In his perception of external relations man is aided by the devices of science, which may be taken up or laid down at will. By means of instruments of precision any of the senses may be extended to an enormous degree, 
and at the same time the personal equation or individual source of error is largely eliminated. The use of instruHyperæsthesia of science. ments of precision is the special characteristic of the advance of science. No instrument of precision can give us the ultimate essence of any part of the universe. No scientific experiment can do away with the measure of human experience as the basis of intelligibility. At the same time we can throw large illuminations into "the dimly lighted room" in which, according to Balfour, the phenomena of consciousness takes place. By the simple process of photography, for example, we may reproduce the objects of our environment. That such pictures do express phases of reality admits of no doubt; for in the photographic camera, all personal equation is eliminated. As to form of outline and reflection of light, "the sun paints true," and the paintings thus made by means of the action of non-living matter produce on our senses impressions coinciding with those of the outside world itself.

How do we know that this is truth? Because belief in it adds to the safety of life; we can trust our lives to Trust in reality makes life safe.

it. If it were an illusion it would kill, because action based on illusion leads to death.

One can trust his life, for example, to the message sent on a telegraph wire. All who travel by rail do this daily. One can trust his life to the reading of a thermometer. The chemist's tests will select for us foods among poisons. We may trust these tests absolutely. We may safely and sometimes wisely take poisons into our bodies if we know what we are doing. By the advice of a physician, trusting in the weigher's instrument of precision, poisons may do no harm. One grain of strychnine may be an aid to vital processes; a dozen 
may mean instant cessation of these processes. The balance advises us as to all this. All these instruments of precision belong to science. They are examples taken from thousands of the methods of " organized common sense." By means of common sense, organized and unorganized, all creatures that can move are enabled to move safely. The security of human life in its relations to environment is a sufficient answer to the "philosophic doubt" of Berkeley and Balfour as to the existence of external Nature; for if all phenomena were within the mind, no one of them could be more dangerous than another. A dream of murder is no more dangerous than a dream of a "pink tea," so long as its action is confined to the limits of the dream. But the relation of life to environment is inseparable and inexorable. Cause and effect are perfectly linked. This is a world of absolute verity, and its demand is absolute obedience. Life without concessions or conditions is the philosopher's dream.

What we know as pain is the necessary danger signal. Without pain, life conditioned by environment Meaning of pain. would be impossible. Organic beings need such stimulus to veracity. Those dangers which are painless are the hardest to avoid; the diseases which are painless are the most difficult to cure.

In this relation must science recognise the value of ideals? The ideal in the mind tends always to go over Value of ideals. into action. The noble ideal discloses itself in a noble life. It is part of the wisdom of each generation, its science as well as its religion, to form the ideals of the next. History is foreshadowed in these ideals before it is enacted on the stage of life. An ideal is not a dream. A dream is fleeting. An ideal has the will behind it. Its essential 
is its persistence. The persistence of a lofty ideal is the central axis of the life worth living.

But if the strong man is to cast off conventionality and suggestion and authority as guides to conduct, so must he guard himself against hereditary impulses. Conventionality and authority hold in check the bodily impulses which had their origin in wild and rude conditions. To escape from human control only to be ruled by the animal passions is not liberty. That "freedom which is thraldom to sin" brings destruction, for the unchecked gratification of bodily impulses carries with it in civilization perils unknown to primitive man. To be free from the control of others one should be wise enough to control himself, and wisdom is but another name for science.

An old parable of the conduct of life shows man in a light skiff in a tortuous channel beset with rocks, The course of life. borne by a falling current to an unknown sea. He is kept alert by the dangers of his situation. As his boat bumps against the rocks he must bestir himself. If this contact were not painful he would not heed it. If it were not destructive he would not need to heed it. Had he no power to act, he could not heed it if he would. But with sensation, will, freedom to act, narrow though the limits of freedom be, his safety rests in some degree in his own hands. That he has thus far steered his course fairly well is shown by the fact that he is still above board. He may choose his course for himself-not an easy thing to do, unless he scan most carefully the nature of rocks and waves, and weighs carefully his control of the boat itself. He may follow the course of others with some degree of the safety they have attained. He may follow his own impulses, in man's case inherited from those who found them safe 
guides to action. But in new conditions neither conventionality nor impulse nor desire will suffice. He must know what is about him in order that he may know what he is doing. He must know what he is doing in order to do anything effectively. Ignorant action is more dangerous than no action at all. The "sealed orders" under which live the lower animals and our "brother organisms the plants" are in a measure inadequate for man. With the power of movement and the "knowledge of good and evil," he has no choice but to

The world as it is.

accept the conditions. He must shape his own life. He must mould his ideals into actuality. And thus it comes that there is "no alleviation for the sufferings of man except through absolute veracity of thought and action, and the resolute facing of the world as it is."

And thus it comes also that it is well for man not "to pretend to know or to believe what he really does not know or believe." We may play at Subordination of impulses. philosophy, if we have pleasure in doing so. We may find intellectual strength through exercise of the mind, even on its own products. But we must guide our lives by science. The appetites, impulses, passions, illusions, if you choose, which have proved safe in the past development of life, science would not destroy. But they must be subordinate to the will and the intellect. And this subordination of the lower to the higher motives in life is the vital fact of human evolution, as it has been the ideal of those who in the name of religion have striven worthily for man's spiritual advancement.

As knowledge is in its essence only a guide to action, and as knowledge, being human, can be approximate only, not reality, but a movement toward reality, we are brought to the famous words of Lessing : 
"It is not the truth in man's possession that makes the worth of man. Possession makes him selfish, lazy, proud. Not through possession, but through long strivThe search ing, comes the ever-growing strength. for truth. If God should hold in his right hand all truth, and in his left hand only the ceaseless struggle to reach after truth, and he should say to me, Choose, I would fall in humbleness before his left hand, and say:

“. Father, give; the perfect truth is but for thee alone." " 
XV.

THE STRUGGLE FOR REALITIES.

IT is said that every tie in the Panama Railway cost a man his life. Whether this be true or not, it may The price of truth. serve as an illustration of the progress of human knowledge. Every step in the advance of science has cost the life of a man. And this price of truth has been paid in two different ways. It may take a lifetime of the severest labour to find out a new fact. No truth comes to man unless he asks for it; and it takes years of patience and devotion to ask of Nature even one new question. He is already a master in science who can suggest a new experiment.

In the second place, the truth-seeker has had to struggle for his physical life. Each acquisition of truth has been resisted by the full force of the inertia of satisfaction with preconceived ideas. Just as a new thought comes to us with a shock which rouses the resistance of our personal conservatism, so a new idea is met and repelled by the conservatism of society.

And as each individual in his own secret heart believes himself in some degree the subject of the favour

The mystic sanction. of the mysterious unseen powers, so does society in all the ages find a mystic or divine warrant for its own attitude toward life or action, whatever that may be. 
The institutions that survive spring out of man's need for them. The existence of the Church has divine warrant in this. Should every fragment of the historic churches disappear, every memory, every ceremony, every trace of creed or form, the Church would rise again, renewed as to all its essentials; and with each variant race of man there would be a corresponding variation in the form of the Church. You could not make Buddhists out of the Puritans, nor transplant the New England Sabbath to the sunny isles of Greece. Monarchy, in turn, exists by the same divine right; and when it fails, the same divinity that hedged the king is invoked to sustain the rights of the people. Once the king was God's anointed, as he still is in many lands. But when "God said, 'I am tired of kings; I suffer them no more," "the self-rule of the people acquired the same divine right-no less, no more, for the warrant rests in the heart of man. We know God's purposes only by what he lets man do. We know what he wills only by what he permits. That which exists in the nature of things men have worshipped as divine, especially if its relations have been dimly understood. Thus the struggle of science with prejudice and tradition has become a warfare with religion; for men have always sought to strengthen their traditional opinions by giving them a religious sanction.

The history of the progress of science has been the record of the physical resistance of organized society.

The struggle against tradition. "By the light of burning heretics Christ's bleeding feet I track." He who sees that the world does move is burned at the stake, that other men may be convinced that it does not. $\mathrm{He}$ who is sure that the rocks were once molten, finds the force of social pressure between him and his studies. $\mathrm{He}$ who would give the sacred books of our civilization 
the faithful scrutiny their vast importance deserves, finds the doors of libraries and universities closed to his research. He who has seen the relation of man to his brother animals, finds the air filled with the vain chatter of those to whom whatever is natural seems only profane. "Extinguished theologians," Huxley tells us, "lie about the cradle of every science, as the strangled snakes beside that of the infant Hercules."

But this, again, is not the whole story. This fact is only an incident in human development. Not only theo-

The struggle against learning. logians lie strangled about the giant's cradle, but learned men of all classes and conditions. Learning and wisdom are not identical; they are not always on speaking terms. Learning looks backward to the past. The word "learn" involves the existence of some man as teacher. Wisdom looks forward to the future. In so far as science is genuine, it is of the nature of wisdom. "To come in when it rains "is the beginning of the science of meteorology. "The soul that sinneth, it shall die," is the practical basis of personal ethics. To be wise is to be ready to act; but learning in all the ages has condemned wisdom and despised action.

It seems to me that the warfare of science is not primarily, as Draper has called it, a conflict with reThe struggle in ligion, nor even, as President White the humanmind. would have it, a struggle with "dogmatic theology." It is all of these, but it is more than these-a conflict of tendencies in the human mind which has worked itself out into history. The great movements of history in general are written in the human mind before they are worked out on the great stage of the world. When history is enacted, we perform deeds and recite sentences "written for us generations before we were born." "He hath his exits and 
his entrances." $\mathrm{He}$ is a rare man who can add a new meaning to his lines or give a better cue to him that follows.

The nervous system of man and animals is primarily a device for making locomotion safe. The mind-using

Nature of the mind. the word in the broadest sense-is a collective term for the operations of the nervous system. It is not an entity existing apart from organization. To it consciousness is related much as the flame is to fire. The mind is in operation whether we realize it or not. The reflex action of the nerve centre is the type of all mind processes. Through the sensory nerves, impressions of the external world are received by the brain or central ganglion. The brain has no source of knowledge other than through sensation. All human knowledge comes through human experience. The primal function of the brain, sitting in darkness, is to convert sensory impressions into impulses of action. To this end are developed the motor nerves which pass from the nerve centre outward to the muscles. The sensory organs are the brain's sole teacher; the muscles are its only servants. The essence of the intellect, as distinguished from reflex or instinctive action, is the choice among different motor responses to the stimulus of external conditions. As the conditions of life grow more complicated, the possible ways in which sensation may pass over into action grow more numerous. It is the function of the intellect to consider these, and of the will to choose. The growth of the intellect causes and permits complexity of life. Safety in life depends upon choosing the right response. Wrong choice leads to failure and death. The power of choice implies the necessity of choosing right.

From this, by the process of natural selection, arises 
the intense practicality of the senses and the intellect. They tell us the truth as to external things, in so far as this truth has been essential to our ancestors. Those of

Practicality of the senses. our predecessors who did not "see things as they really are," to the degree that their life processes demanded, have died, leaving no descendants. Our own ancestors, through all the generations, have been creatures of adequate sensations and of adequate power of thought. Were it not so, they would have been unable to cope with their environment. In other words, the sensations their brains translated into action were truthful enough to make action safe. That our ordinary sensations and our inductions from them are truthful so far as they go, is proved by the fact that we have safely trusted them. This is shown also by the instruments of precision which are the tools of science. That instruments of precision likewise tell the truth, is shown by the fact that we can trust our lives to them. That they are more trustworthy than the unaided senses, is shown by their greater safety.

But while our senses tell the truth as to familiar things, as rocks and trees, foods and shelter, friends and enemies, they do not tell the whole truth. They go only as far as the demands of the environment have compelled them to go. Chemical composition they do not show. Objects too small to be handled are too small to be seen. Bodies too distant to be reached are never correctly apprehended. Accuracy of sense grows less as the square of the distance increases; and sun and stars, clouds and sky, are in fact very different from what they seem.

In matters not vital to action exact knowledge loses its importance. It is perfectly safe, in the ordinary affairs of life, to believe in witches and incantations, 
imps and elves, astral bodies and odic forces. It is quite as consistent with ordinary virtue and effectiveness to accept these as objective realities, as it is to have the vague faith in microbes and molecules, mahatmas and protoplasm, in protective tariffs and manifest destiny, which form part of the mental outfit of the man of our day. Unless these ideas are brought into terms of personal experience, they can not be wrought into action. If they are so brought, truth is separated from falsehood, and the vague conceptions most men possess are found to diverge very widely from the actual facts in Nature. Thus, when one comes to handle microbes, they become as real as nutmegs or oranges, and as capable of being manipulated. But the astral body exists only to those who use it as a cover for real ignorance, and the ghosts vanish when we turn on the electric light.

Other mental processes arise to produce confusion. Memory pictures readily blend themselves with realities. The nervous system of the one individuSuggestion and conventionality. al is easily affected by the conditions existing in another. Men are gregarious creatures, and their speech gives them the power to add to their own ideas and experiences the ideas and experiences of others. Thus, many actions are based not on our own sensations, but on the suggestions of others. Openness to suggestion and the instinct of conventionality are elements of great importance in insuring the safety of gregarious creatures.

With all this, the growth of each individual must be determined by his own experience. About the senseimpressions formed in my own brain I must build up my own universe. Thus it comes that each accretion of human knowledge must be thrown into terms of our previous experience. Stated in these terms, it is always 
imperfectly stated. By processes of suggestion and conventionality the ideas of the individual become assimilated to those of the multitude. Thus tradition and myths arise to account for phenomena not clearly related to the ordinary experiences of life. And the unknown in all mythology is ascribed not to natural forces, but to the action of the power that transcends Nature.

It has been evident to man in all ages that there lie about him forces stronger than he, invisible and intanThe forces outside ourselves. gible, inscrutable as to their real nature, but none the less potent. He can not easily trace cause and effect in dealing with these forces, and it is natural that he should doubt the existence of causation in the phenomena they produce. As the human will seems capricious because the springs of volition are hidden from our observation, so to the unknown will that limits our own has been ascribed an infinite caprice. All races of men capable of continued thought have come to believe in the existence of something outside themselves, whose power is without human limitations. Through the imagination of great poets these forces become personified. The existence of power seems to demand a will. The power is infinitely greater than ours, the sources of action inscrutable; hence man has conceived the unknown First Cause as an infinite and unconditioned man. Anthropomorphism in some degree is inevitable, because each man must think in terms of his own experience. Into his own universe all that he knows must come.

Recognition of the hidden but gigantic forces in $\mathrm{Na}$ ture leads men to fear them and to worship them. To think of them, either in fear or worship, is to give them human forms. To grant them the form of man is to give them "a local habitation and a name." As man is a social animal, even in his hopes and fears, these feel- 
ings have given rise to institutions. An institution implies a division of labour; so in every age and in every race men have been chosen and set apart Fearand worship as representatives of these hidden forces of the unseen powers.

and devoted to their propitiation. In every nation there are men who are commissioned to speak in the name of each god that is worshipped or each demon that the people dread.

The existence of each cult of priests is bound up in the perpetuation of the mysteries and traditions they visibly represent. It is the nature of men to magnify their own calling. These traditions are associated with other traditions of other powers, with other conventional explanations of uncomprehended phenomena. While human theories of the earth, the stars, and the clouds, of earthquakes, storms, comets, and disease, have no direct relation to the feeling of worship, yet of necessity they become entangled with it. The uncomprehended, the unfamiliar, and the supernatural are one and the same thing in the mind of man. History shows that the human mind can not separate one set of traditional prejudices from another.

We come to attach sacredness to the ideas acquired in our youth, whether derived from our own experience

The science of our childhood. or from the teachings of our fathers. To those courses of action approved by us as right we attach a mystic sanction as our best reason for following them. And not only to the acts of virtue approved by the ethical wisdom of all ages, but to the most unimportant rites and ceremonies we attribute the same divine sanction. New ideas, without the sanction of tradition, whatever the nature of their source, must struggle for acceptance. To the scientific notions of our childhood we cling with special persistence, because they are associated with our con- 
ceptions of right-doing and of the motives which control it. Both are part of the mental universe we built around us in our youth, and one in which we would not willingly make changes or extensions.

It is the work of science to find in some degree the real nature of the universe. Its function is to eliminate, as far as may be, the human equation in every statement. By methods of precision of thought and instruments of precision of observation science seeks to make our knowledge of the small, the distant, the invisible, the mysterious, as accurate as our knowledge of the common things with which man has dealt for ages. It seeks to make our knowledge of common things accurate and precise, that this accuracy and precision may be translated into action. For the ultimate end of science, as well as its initial impulse, is the regulation of human conduct. Seeing true means thinking right. Right thinking means right action. To bring about right action is the end of science. Greater precision of thought and action makes higher civilization possible. Lack of precision in action is the great cause of human misery, for misery is Nature's protest against the results of wrong conduct. "The world as it is " is the province of science. "The God of the things as "The world as it is." they are" is the God of the highest heaven. As "the world as it is" to the sane man is glorious, beautiful, noble, and divine, so will science be the inspiration of art, poetry, and religion.

The intellectual growth of man has

The conflict between science and religion. been one long struggle between the ideas of the universe derived directly from realities and the ideas derived from tradition and suggestion. The record of this struggle is the most valuable part of history. In his notable record of this struggle Dr. John W. Draper has called it "The 
Conflict between Religion and Science." But the inadequacy of this definition has been generally recognised, for the conflict has chiefly lain between religious institutions and the progress of knowledge.

Andrew Dickson White calls this "the struggle be-

The struggle between science and dogmatic theology. tween science and dogmatic theology, ... the conflict between two epochs in the evolution of human thought-the theological and the scientific." This idea was years ago crystallized by him in these memorable words:

"In all modern history, interference with science in the supposed interest of religion, no matter how conscientious such interference may have been, has resulted in the direst evils both to religion and to science, and invariably; and on the other hand, all untrammelled scientific investigation, no matter how dangerous to religion some of its stages may have seemed for the time to be, has invariably resulted in the highest good, both of religion and of science."

From the standpoint of history, this struggle has actually been one between organized theology and unorganized science. Preconceived notions of theological science became entangled with crude notions of all other sciences. In the experience of a single human life there is little to correct even the crudest theology. From the supposed greater importance of theology in determining the fate of the individual man, theological conceptions have dominated all others. Throughout the ages the great churches have been the stronghold of conservatism. Religious bodies have formed the great organized army against which the separated bands of science hurled themselves apparently in vain.

But as I have said before, the real essence of conservatism lies not in theology. The whole conflict is a struggle in the mind of man. It exists in human psy- 
chology before it is wrought out in human history. It is the struggle of realities against tradition and suggestion. The progress of civilization would The essence of conservatism. still have been just such a struggle had religion or theology or churches or worship never existed. But such a conception is impossible, because the need for all these is part of the actual development of man.

Intolerance and prejudice are, moreover, not confined to religious organizations. The same spirit that

The effort to limit thought.

burned Michael Servetus and Giordano Bruno for the heresies of science, led the atheist "liberal" mob of Paris to send to the scaffold the great chemist Lavoisier, "with the sneer that the republic has no need of savants." The same spirit that leads the orthodox Gladstone to reject natural selection because it "relieves God of the labour of creation," causes the heterodox Haeckel to condemn Weismann's theories of heredity, not because they are at variance with facts, but because such questions are settled once for all by the great philosophic dictum of monism.

There is no better antidote to bigotry than the study of the growth of knowledge. There is no chapter in man's history more encouraging than that which treats of the gradual growth of open-mindedness. The study of this history will bring religious men to avoid the mistakes of intolerance through a knowledge of the evils to which intolerance has led in the past. Scientific men will be spurred to better work by the record that through the ages objective truth has been the final test of all ideas. All men will be more sane and more effective in proportion as they realize that no good can come from "wishing to please God with a lie."

The conflict of science is usually considered as the 
struggle of dogmatism to limit knowledge. But another phase of the same warfare is the desire of organized conservatism to limit action. Just as science goes over into action, so does dogmatism pass over into suppression. The struggle for democracy, the rise of the common man, is therefore part of the same great conflict for human freedom.

The desire of dogmatism to control action is in its essence the desire to save men from their own folly.

The effort to control action.

The great historic churches have existed "for the benefit of the weak and the poor." By their observances they have stimulated the spirit of devotion. By their commands they have protected men from unwise action. By their condemnations they have saved men from the grasp of vice and crime.

But the control of action by an institution is irksome to the man who thinks for himself. Whoever thinks for himself must act for himself. He is no longer subject to "sealed orders," even though their origin be divine. And the command "to work out his own salvation," in such way as he may, is fatal to his salvation through the means provided by the Church.

As it is natural that man should create the Church out of his own need for it, so is it natural that he should The passing of institutions. rebel against its control when he shall need it no longer. Individual freedom is the goal of intellectual progress. It is "that far-off divine event toward which the whole creation moves." It is, therefore, in the highest degree natural, and to call it supernatural is to say the same thing, that man should cast off the fetters of traditional sanction as the sanction of higher wisdom arises to take its place. 


\section{N D E X.}

Absolute truth, 336.

Abstinence, good reason for, 276.

Acceleration, 8I.

law of, 230, $23 x$. of development, 26 .

Acquired characters, $\mathbf{I}_{3}$. inheritance of, 42, 97 . transmission of, 82,83 .

Adaptation, 26, 87, 200. by divergence, 69 . not progress, 68.

Adolescence, 272.

Adolescent stage, 235.

Adult stage, 235 .

Agassiz, latest and greatest opponent of theory of derivation, 43 .

Agassiz, on embryonic development, 23 I.

on facts, 29.

on thoughts of God, 345 .

on unity of type, 8,9 .

Aggregation of cells, 93 .

Alfred the Great, I4I, I42.

Algæ, reproduction of, 164 .

Algebraic expression of heredity, I24.

Allah's will, 289.

Allen, on definition of species, 2 r6.

on variation in Florida birds, 215. All life from life, xo.

Altruism, 90.

in lower animals, 92.

of parenthood, 315 .

value of, 28.
Amaltheus, 249.

Ammonidea, numbers of, 245 .

Ammonites, 234.

Amphiaster, 154 .

Anaphases, 156, 157.

Anarcestes, 236, 243, 253.

Ancestors, 141, 142.

Ancon sheep, II5.

Ancylobranchia, 238.

Angel fish, 225.

Angelichthys ciliaris, 225.

Anguilla, 43.

Animal pauperism, 279.

Anomalies in distribution, 200.

Ant-eater of Australia, 40.

Antedon, 237.

Anthropoid apes, 67 .

Aosta, cretins of, 284-286.

Arcestidæ, 244.

Archoplasm, 151.

Arctic birch, 208.

Arpadetes, 234.

Artemia, 112.

Arthaber on ammonites, 249.

Articles of scientific faith, 346 .

Artificial selection, 19 .

Ascaris, 153.

development of eggs of, 155,159 , 160.

Assimilation, 103, 104.

Assisted immigration, 308.

Aster, 154.

Astral body, 352. 
Astrosphere, 154 .

Attention, 274.

Attraction sphere, r5I.

Australia, animal plagues of, 202.

Australian realm, r9g.

Authority, 356.

Bacteria, reproduction of, $\mathbf{I} \mathbf{6}_{3}$.

Bactrites, 243.

Baculites, 245, 250.

Bagehot on nonsense, 291.

Baird on variations of birds, 214 .

Balanoglossus, 107.

Balfour on belief, 334,336 . on doubt of realities, 354 .

Barbara on goblins, 354 .

Barrande on trilobites, 239.

Barriers to diffusion, Ic6. to distribution, 206.

Barry on larva of sea urchins, 237.

Battle of the parts, 27.

Baur, origin of mammals. 230 .

Beagle, voyage of the, 16 .

Beauty as a weapon of defence, $3 \mathrm{I} 8$. of young girls, 318.

Beecher on evolution of brachiopods, 238.

Beecher on larval stages of trilobites, 239.

Bees in New Zealand, 202.

Berkeley on doubt of realities, 354 .

Belief and knowledge, 335 .

Belief, foundation of, 336,340 .

Benevolence, sins of, 307 .

Bergen on adaptation, 26.

on cumulative evidence, I9r. on geological evolution, 32 .

on natural selection, 26 .

Bering Sea Commission, 269.

Birch, 208.

Birds of the Galapagos, 13, 193.

Bionomics, $5^{8}$.

Biophores, 104, 177, 178 .

Bismarck, on the educated proletariat, 295.

Bob, a monkey, 266.
Bohun, lineage of, 142.

Borderland dwellers, 290.

Borderlanders, 290.

Borderland of spirit, 274, 340.

Boveri, on centrosome, 151.

on cleavage of chromatin, $185-187$, 189.

on development of egg cells, $\mathbf{1 8 4}$.

on fertilization of egg, 173.

on generation of egg cells, 159.

Blood relationship, $4^{8}$.

Blue blood, 128, 144.

Bosanquet, on essence of prayer, 61 .

Boyesen, on evolution, 53.

Branchiata, 112.

Branco, on ammonites, 246. on larval ammonites, 25 I.

Brauer, on development of sperm cells, $x 84$.

Brewer, on continued starvation, 112.

Brooks, on brachiopods, 238.

on heredity, 125, 126.

Brother Jonathan, lineage of, $\mathbf{I} 45$.

Brown-Séquard, on mutilations, 115.

Brücke, on structure and life, ro4.

Bruno, burning of, 376 .

Byron, on woman's education, 324 .

Caldwell, on monotremes, 40.

Cape Verde Islands, 13, 193.

Carbon molecule, 347 .

Cells, 148, 149.

Cell theory, 147.

Cell, unit of life forces, 103.

Centrosome, 15r, 154.

Cephalization, 227.

Cephalopoda, evolution of, $229,240$.

Ceratites, 234.

Ceratitidæ, 244 .

Cercopithecus, 266.

Chain of life, 355 .

Chamfort, on woman's position, 323 .

Cliange not progress, 32.

Characters innate or acquired, I3I.

latent and potent, I04.

not necessarily useful, 218 . 
Charity creates misery, 283 .

true function of, $3 \mathrm{II}$.

Cherry, origin of the name, 217.

Chilodon, $x 62$.

Chromatin, 3, 121, 15x. bearer of hereditary influences, 185 .

Chromosomes, 153 .

reduction of, 176,178 .

splitting of, 155 .

City life, 227.

Cirripedia, species of, 213.

City of the dreadful night, 3 or.

Clam, long siphon of, 114.

Clarke on evolution of brachiopods, 238.

Clavier theory, 270.

Clem murder, 304 .

Climate a barrier to distribution, 206.

Clover and bees, 2 I.

Clymenia, 245.

Colburn on philosophic belief, 35 r.

Colonial consciousness, 27 r.

Compensation, law of, 94 .

Complex components in development, 103.

Complex structures, origin of, 34 .

Conception, political, 307, 309 .

Concessions of life, 77 .

Cogito ergo sum, 271.

Conjugation, 166, 167 . of infusoria, 92, 163 . of protozoa, 162 .

Conklin on factors of evolution, 100.

Consciousness, 256, 271.

Conservatism, 376 .

Conventionality, $356,37 x$.

Co-operation of cells, 93 .

Cope, factors of organic evolution, III.

on acceleration, 26.

on doubtful species, 212.

on factors in development, I02.

on fossil reptiles, 40 .

on Lamarckian factors, $x 16$.

on retardation, 233.
Cope on stretch and impact of bones, II5. on variation in shells, II. origin of reptiles, 230 .

Copepods, 18r.

Coral reefs, centre of life, 225 .

Corpuscular theory a necessary makeshift, ro4.

Cosmic order, function of law, 63 .

Cottontail, 24.

Coues on definition of species, 216. on meaning of species, 44 . on migration, 195.

Course of life, 363 .

Courteney, lineage of, 142 .

Crackers, 306.

Cramer on lessons of Darwin's work, 64.

Creation, method of, 10.

Cress in New Zealand, 204.

Cretins, 284. marriage of, 286 .

Crinoids, 229.

Crioceras, 250.

Crustacea, evolution of, 239.

Cumulative evidence, 192.

Cuvier on special creation, 7 .

Cycloids, 229.

Cyclops, 181.

Cyrtoceras, 24I.

Cytoblastema, 152.

Cytolymph, 150.

Cytoplasm, 103, 150, 154,167 .

Dareste on origin of eels, 43 .

Darters, 46.

Darwin in Westminster, 52. on cirripedia, 213 . on evidence of embryology, 37 . on isolation, $x g 2$.

on law, 58 .

on meaning of facts, 64 .

on gemmules, ro4.

on secondary causes, $5 \mathrm{r}$.

on struggle for existence, 85,86 .

on dependence of species, 208. 
Darwin on theology and science, 50. spirit of, 53 .

studies of the Galapagos, 12.

Darwin's confidence in future, 42. home, 52.

origin of species, 17

plan of work, 16.

Darwinian hypothesis, 69 . theory, 17.

Darwinism, 30, 64, 117. a working hypothesis, 65 . objections to, 42. not compelled by authority, 45 .

Daughter cells, 156.

Dead hands in heredity, 124.

Death, value of, 28 .

Decadence, causes of, 295.

Decadent literature, 294.

De Candolle on definition of species, 212.

Degenerates, 290.

Degeneration, 273, 277, 280, 281. in inactivity, 302. in isolation, 287 . in luxury, 289. in slavery, 288 . in the slums, 288. in the tropics, 288. of eels, 228. of marine animals, 277. of mental dyspepsia, 290. of parasites, 278 . of races, 282 . of senility, 282 . through charity, 283 . under institutions, 297.

Dégénerés supérieurs, 290.

Descent, theory of, 47.

Despondency in Europe, 295.

Determinants, 177 .

De Vries on pangenes, $104, \mathbf{1 7} 8$.

Dickinson on plagues of Australia, 202.

Diener on ammonites, 249.

Direct division in cells, $15^{8}$.

Disuse a factor in development, 113.
Diversity in life, 3 .

Distribution of fishes, 86. of species, $19 \mathbf{r}$.

Dogmatism in control of action, 377 .

Doubtful species, 212.

Down, the home of Darwin, 52 .

Drake, the lineage of, 142. of Windsor, 143.

Draper on conflict with religion, 368 .

Driesch on unknowable factors, 98.

Drugs, effect of, 275 .

Duck bill, 40.

Dugdale, 303 . on the Jukes, 287.

Dwight on variations in shore larks, 214.

Echinoderms, development of, 237. eggs of, 107.

Echinus, 175. microtuberculatus, $\mathbf{I} 86$.

Edentates of South America, 14.

Edwards on lineage of a little girl, 142.

Edwards, Mary Stockton, 142.

Eels, origin of, 43, 228.

Effort, 89. of animals, 26.

Egg-bearing, reflex effect of, $3{ }^{1} 3$. cell, development of, $170,172$. maturing of, 170. of mammals, 39 . of metazoa, 168 .

Ego, 138, 140, 270. a co-operation, 140 . development of, 272.

Egomania, 294.

Elderkin, lineage of, 142.

Embryo in egg at all stages, ro8.

Embryology, 35-37. testimony of, roo.

Embryonic development, 23x. formula, 139. stage, 235. structures in man, 40.

Embryo primarily sexless, 136. 
Embryo, reduction in numbers of, Factors of organic evolution, Ico.

314 .

Emerson on pretending to know, 349.

on soundness of life, $6 \mathrm{r}$.

on the wholesome world, 297 .

Endoceras, 24I.

Energide, 148.

Englishman, origin of, 145 .

Ennui, 274.

Entomoceras, 250.

Environment, influence of, 77 .

Ephebic stage, 235 .

Epoch-making events, 32.

Equilibrium of Nature, 23, 208.

Essential parts of cell, 149.

Eternal womanly, the, 3I5.

Ethiopian realm, 198.

Eudorina, 166.

Evermann on Two-Ocean Pass, 205.

Evolution, 54.

a method of study, 65 .

and pessimism, $3^{\text {r6. }}$

as a theory, 63 .

a system of cosmic philosophy, 65.

by leaps, 69 .

inorganic, 57 .

method of, 100.

not a creed, 73 .

not a religion, 73 .

not dynamic, 88.

not occult, 73 .

of home, 329 .

of mind, 256 .

orderly change, 70 .

organic, 57.

philosophy of, $46,316$.

Spencer's formula of, 47 .

of woman, 312 .

Exact and inexact sciences, 59 .

Experience and knowledge, 337. inadequate, 337.

External stimulus, 257.

Extinction of animals, 206.

Extrinsic causes of change, Ior. unknown, 98.

Failing beliefs claim orthodoxy, 5o.

Fame and greatness, 140.

Fauna, analogy to language, 217.

Fear, 373.

Fearn on prenatal influences, $I_{35}$.

Fertilization of egg, $\mathbf{1 7 3}_{73}, \mathbf{1}_{74}$.

Fichte on the ego, 140.

Firehole River, 205.

Fishes, evolution of, 221.

Fiske on method of evolution, 65 .

on prolonged infancy, 329 .

Fitness, 18.

Flounders, vertebræ of, 221.

Flying-fish, 211.

Food yolk in egg, 39 .

Fool-killing, 359 .

killer, 358.

Foreign immigration, 308.

Forces as thoughts of God, 9.

Formula of the embryo, 137 .

Formulæ, decay of, 66.

Foundations of belief, 336,340 .

Foxes in Australia, 304.

Frederic on development of boys, 326.

Function before structure, 256 .

Fundulus, eggs of, 106.

Fur seal, homing of the, 265 .

intellect of, 269.

Galapagos Islands, 12, 192.

Galton on acquired characters, $35 \mathrm{I}$. on degeneration of blue blood, 144. on quantitative estimate of heredi-

ty, 127.

on mid-parent, 125.

Gasteropods, III.

Gastrioceras, 244.

Gate of Gifts, 133 .

Geddes on bionomics, 58 .

Gemmules, 104.

Genius not a disease of the nerves, 293.

Geographical variations, 211, 214. 
Geographical distribution, 31.

Geological record, 230.

Germ cell, 121. cells fundamentally alike, $\mathbf{r} 69$. cells, specialization of, $3^{1} 3$.

Germinal protoplasm, Ior. variation, $8 \mathbf{1}$.

Germ-plasm, stability of, rog.

Geometric increase, 20,

Gerontic stage, 235.

Gill slits in man, 4I.

Girls, beauty of, 318 .

Gladstone on natural selection, 376 .

Glyphioceras, 253, 254.

Goblins, reality of, 354 .

God, growing conception of, $5 \mathrm{I}$.

Goethe on heredity, 27, 118 . the " sanest of men," 8.

Goodale on artificial selection, 19.

Goniatites, 244 .

Graf, on colours of leeches, 106.

Gray, evidence for derivation, 220. on plants as thermometers, 206.

Great Smoky Mountains, 287.

Green on increase of sparrows, 22.

Greenling, 224.

Grenville, lineage of, 142.

Grönlund on woman's work, 332.

Guelph, house of, 142.

Günther on British salmon, 46.

Gyroceras, 24I.

Haacke on monotremes, 40.

Haeckel, confession of faith, 346 .

on acquired characters, 350 .

on belief, 349.

on law of development, 233 .

on monism, 346.

on the gaseous vertebrate, 340 .

on the maker of life, 347 .

on Weismannism, 376.

Haeckel's orthodoxy, 352.

Hares, species of, 24.

Hatschek, phylogenetic changes, 108. Hatteria, 34.

Haug on ammonites, 350 .
Hawiey, lineage of, 142 .

Hearts insurgent, 295.

Hegel, orgy of ego of, 140.

Helmholtz on philosophy, 342 .

Henneguy on reproduction of infusor ria, 163.

Henshaw on variation in shore larks, 214.

Herbst on eggs of echinoderms, 107. Herbst's experiments on larvæ, 113.

Hercules, strangling snakes, 268.

Heredity, 75 .

algebraic expression of, 124 .

of inefficiency, 299.

of Richard Roe, 118.

physical basis of, $76,147$.

Hertwig, idioblasts, 104, 178 .

on size of sperm cell, I73.

Hexagrammos decagrammus, 224.

Higher foolishness, 290.

heredity, 262.

Hirsch on degeneration, 290.

His on intrinsic causes, 102.

Holarctic realm, 196.

Holmes on John's John, 338.

Home, evolution of, 329.

Homing instinct, 265.

Homogeneity to heterogeneity, 47 .

Homology, 3 .

meaning of, $4,18,48,64$.

origin of, 5 .

Homo sapiens, 2 II.

Hooker, letter from Darwin, 15. on life in New Zealand, 202.

Horned larks, 214.

Huggins, pauper record of, 306 .

Hundsōire, 209.

Huxley on England's greatness, 22. on extinguished theologians, 50. on human suffering, 354 .

on make-believe, 350 .

on materialistic symbols, 270 .

on Nature's obduracy, $x 6$.

on persistence of energy, 55 .

on theologians, 368 .

Hyatt on acceleration, 233. 
Hyatt on ontogeny of ammonites, 250.

on orthoceras, $24 \mathrm{I}$.

Hyperæsthesia, 274.

Hysteria, 275, 294.

Ibergiceras, 236 .

Ibsen's characters, 293. ghosts, 136 .

Ichthyocrinoidea, 237.

Ichthyization, 225.

Idants, 177.

Ideals, 362 .

Idioblasts, 104, 178.

Ids, 177 .

Illusions, 263.

Impact of bones, 115 .

Impulse and action, 273.

In-and-in breeding, 128 .

Indianapolis, pauper record of, 304.

Indian realm, 198.

Individual an epitome of race, 36 .

Individualism in character, 298.

Individuality, 80.

Inefficiency, 299.

Infinite Being, 34I.

Inherited characters predetermined, IоI.

Inheritance of humanity, 120.

of individuality, 120 .

of race, 120.

Innate characters, $13 x$.

Inspired idiots, 290.

Instability, 257.

Instinct, 265, 356 . and intellect, 369 .

Institutions, degeneration under, 297. passing of, 377 .

Intellect, 265,357 . choice of responses, 268 . nature of, 369 .

Intrinsic causes, ror. forces and protoplasmic structure, ror.

Invasion of weeds, 201.

Isolation, 96, 195 .
Isolation, degeneration in, 287 .

Ishmael, tribe of, 304 .

Jackson on evolution of echinoderms, 237.

on pelecypoda, 240.

on siphons of clams, II4.

Jacob and Laban, $\mathbf{r}_{34}$.

James on philosophy, 343.

Jenkins on Two-Ocean Pass, 206.

John Bull, lineage of, 145 .

John's John, 338.

Jordan, lineage of, 142 .

Jocko, 266.

Jukes, degeneracy of, 287 .

Kant on philosophic revery, 296.

Karpinsky on development of ammonites, 236.

on larval ammonites, 25 r.

Karyokinesis, $1_{52}, 1_{57},{ }^{88}, 1_{77}$.

Katagenesis, 102.

Kelvin on size of molecule, 348 .

Kindness of woman, 3 rg.

King on "the rotten side of things," 292.

Kingsley on embryological evidence, 37.

Kinship and homology, 49. of life, $\mathbf{r}$.

the sacred, 53 .

Knowing and believing, 35r.

Knowledge and belief, 344 .

will, and obedience, 276 .

Kovalevski on brachiopods, 238.

Lacaze-Duthiers on brachiopods, 238 .

Lady-nuisance, 324.

Lamarck, laws of heredity, 82.

on transmutation of species, 8 .

Lamarckian factors, 1 r6.

principle, the, $x$ ro.

theory, 115 .

Language, analogy to a fauna, 217. 
Lankester on degeneration, 305 .

Larval stage, 235.

Latent characters, IO4.

Latitude and vertebræ, 22 I.

Lavoisier, murder of, 376.

Law as sequence of events, 58 . meaning of, 59.

Laws, not broken nor repealed, $6 x$. of distribution, 96 . of distribution of animals, 206.

Learning and wisdom, 368.

Ledsmar, Dr., $3^{26}$.

Leeches, colours of, 107.

Lepus americanus, 24. sylvaticus, 24.

Lessing on perfect truth, $341,3^{64}$.

Life a function of organization, I06. Linnæus, view of species, 2, 6 .

Lituites, 242.

Locomotion and sensation, $26 r$.

Loco-weeds, 268.

Locust in Australia, 204.

Loeb on inheritance of heat, ro7. on striping of fish eggs, 106.

Logical necessity, 349.

Lombroso on mattoids, 290.

Lord-nuisance, 327.

Love, value of, 28 .

Lowell on dominion, $256,276$.

Luxury, degeneration in, 289.

Lytoceras, 245.

Mattoids, 283, 290, 291.

Maturity of woman, 319.

Maudsley, 290.

McCulloch on combination, 91 . on indiscriminate charity, 3 ว.

McFarland on physical basis of heredity, 147.

Meckel on embryonic development, 231.

Medlicottia, 236, 244 .

Mental pauperism, 298.

Metabolism, xo3. $_{3}$

Metaphases, 157 .

Metazoa, reproduction in, $162, x 68$.
Micellæ, x04, $x 78$.

Mid-parent, the, 125.

Migration changes species, 195 .

Militarism, effect on woman, $33^{\circ}$.

Military selection, 284 .

Miller on tropical forests, Ig8.

Miltites, 247.

Macacus, 266.

Mackerel, 223.

Macroscaphites, 245.

Magnan, 290.

Maker of life the carbon molecule, 347.

Malthus, doctrine of, $2 x$.

law of population, 86.

Man a developed monkey, 67 .

origin of, 47 .

Maoris in New Zealand, 202.

Marcus Aurelius, 292.

Marriage, equal, 332.

laws, 325.

Marsh, origin of the horse, 230.

Marvels of life, $25^{8}$.

Maternity, 3I4.

Material basis of heredity, $\mathbf{1 9 0 .}$

Materialistic symbols, 2 \%o.

Matter relations not realities, 339.

Milton's view of creation, Io.

Mimoceras, 243.

Mind, evolution of, 256.

in plants, 260 .

nature of, 369 .

Minnows, 46 .

Nisery from charity, $28_{3}$.

Missing links, 48, 215 .

Mistletoe, 20.

Mojsisovic, on ammonites, 249.

Mollusca, evolution of, 239.

Monism, 7x, 346.

not science, 347 .

Monistic confession, 353 .

Monkey geniuses, 290.

Monkeys, homologies with men, 50. intellect and instinct in, 266.

Mono, 266.

Monotremes, 40. 
Morse on brachiopods, 238.

Multicellular organisms, 149.

Mutilations, II5.

Mutual help, 95 .

preserves incapables, 300 .

Mya, II4.

Mysticism, 294.

Năgeli, 152.

on micella groups, ro4, 178 .

on preformation in embryo, ro3.

Nations, sanity of, 276 .

Natural and supernatural, 58 .

Natural selection, $18,19,83$. in race development, $\mathbf{1 4 5}$.

Nature as figure of speech, 62 . insensibility of, $6 \mathrm{r}$.

Nautilus, 240.

Neamic stage, 235.

Negro suffrage a choice of evils, 308.

Neo-Lamarckism, 13r.

Neo-Lamarckian school, 82.

Neotropical realm, igs.

Nepeonic stage, 235 .

Neptunism, 351.

Newman on dependence of clover on bees, 22.

Newton, 52.

in Westminster Abbey, 74.

New Zealand, changes in life, zor.

Nietsche, ownership of day after tomorrow, 292.

Nordau on degenerates, 290. on degeneration, 289 . on the normal man, 292.

Norman blood, $\mathbf{1 4 2}$.

Normal man, 292.

Nucleoli, 15 I.

Nucleus, $\mathbf{1}_{50}$, 153 .

Nutrition, 97. diminution of, IIr.

Objections to Darwinism, 4I.

Omne vivum ex vivo, 71 .

Omnis cellula e cellula, 152 .
Ontogeny, roo.

Ontogenetic stages, 235.

Organic evolution, elements of, 75 .

factors of, roo.

science of, 55 .

Organism, 103.

Origin of the fittest, 83 .

Origin of man, 47 .

Orthoceras, 24I, 242.

Osborn on Lamarckism, II5. on prenatal influences, 134 . on variation, $8 \mathrm{r}$.

on supposititious factors, 98 .

on unknown factors, 98 .

Otocoris alpestris, 214 .

Ovogonia, I7o.

Owls, white in winter, 25.

Pacific Railway survey, 213.

Pain, 362.

Paleontogeny, 236.

Pandorina, 164, 165.

Pangenes, 104, 178.

Pantheism, 346.

Paralegoceras, 244, 254.

Parasites, 278.

Parasitism, source of corruption, 307.

Passenger pigeons, 207.

Pattison, quotation from Kant, 296.

Pauperism, 279. and poverty, 30 .

Paupers as parasites, 307 .

Pelecypoda, 240.

Pentacrinus, 237.

Pessimism, 3 I 6.

condemnation of, 273 .

view of woman, 326 .

woman of, 3 12.

Philosophy and truth, 342 .

Philosophy as schlechtes Stoff, 342.

Phrynosoma blainvillei, 35 .

Phylogeny, 100, 230.

Physical basis of heredity, 147 .

Physiological isolation, 219. units, $104,177,178$. 
Pigeons, extermination of, 207.

Pikes, 306.

Pinacoceratidæ, 244.

Pineal eye, 34.

Plantagenet, lineage of, 142.

Plasomes, 104, 178.

Pluteus, 107.

Plutonism, 35I.

Polar bodies, 17 .

Pompeckj on abnormal ammonites, 245.

Poor whites, 287.

Popanoceras, 244.

Poronorites, 244.

Porto Santo rabbit, 96 .

Potentialities only inherited, 13 r.

Poulton's experiments on colours of larvæ, II4.

Poverty, 301.

Practicality of senses, 357 .

Prayer, essence of, 6r.

Predetermination in the egg, 105.

Prenatal influences, 133-r $_{3} 3$.

Primogeniture, 142-144.

Prionoceras, 254.

Progress and poverty, 357.

Progression, supposed innate tendency of, 70 .

Prolecanitidæ, 244.

Promedlicottia, 236.

Pronontes, 236, 244 .

Propelacanites, 236.

Prophases, 157.

Protoplasm, 2, 101, 103, 121, 150, 346.

Protozoa, equality of sex in, $3_{12}$. functions of, 257. reproduction of, 162 .

Protyl, 343.

Psiloceras, 247.

Psychic changes, 256. phenomena, 274.

Ptarmigans, white in winter, 25.

Quantitative estimate of heredity, 127.
Quenstedt on Jurassic ammonites, $243,249$.

Quiescent animals, 277.

Rabbit, species of, 24 .

Rabbits in Australia, 202, 203. white in winter, 24.

Race degeneration, 282. types, 146.

Rain, law of, 60.

Rauber on frogs' eggs, 185 .

Reade on woman's secrecy, 319.

Realms of life, $\mathbf{s} 6$.

Realities, 262. struggle for, 366 .

trust in, 360.

Reason inadequate, 337.

Recrudescence of superstition, 358.

Reduction of chromosomes, 178 .

Reflex action, 26r.

Reid on acquired characters, I3I.

Reincarnation, 349.

Religion, 345 .

Remak, 152.

Reproduction, 162.

Reproductive tissues, $15^{8}$.

Retardation, 82, 233.

Revery, 254 .

Richard Roe, heredity of, Ir8.

Rickert on reproduction of Cyclops, I8r, 182 .

Riley on "goblins that get you," 354.

Rock-fish, 224.

Romanes on Lamarckian factors, II6.

on mutilations, Ir5.

on unknown factors, 98 .

on Weismann's theories, 1 Io.

Ross on despair, 295.

on the ego, 139.

Rousseau on woman's genius, 322 .

Roux on components of development, 102.

on the final word, II7.

on nuclear division, 176 . 
Sacculina, 278-280, 303.

Sachs on energides, I 48 .

Saint-Hilaire on derivation of species, 8.

Salic law, 324.

Salisbury on belief, 334 . on knowledge, 336.

Saltatory evolution, 69 .

Salvation Army, 274.

Sanction, mystic, 366 .

Sanity, 340. of life, 276.

Science as altruism, 335 . devices of, 360 .

its limits, 553.

its own witness, 74 .

Schenck on sex control, 137.

Schizomycetes, 163 .

Schleiden on cells of plants, 147, I52.

Schloenbachia, 254.

Schmankewitsch on development of shrimps, I I2.

Schopenhauer on freedom from marriage, 329 .

on marriage, 325 .

on pessimism, 315 .

on woman, 317 .

Schuchert on evolution of brachiopods, 238.

Schultze on cell structure, 147 .

Schurman on ultimate truth, 34 r.

Schwann on cells of animals, 147, 152.

Scott on unknown factors, 98 .

Sealed orders, 377 .

Sea urchins, development of, 237. urchin, egg of, 175 .

Sebastodes miniatus, 224 .

Secondary causes, $50,5 \mathrm{I}$.

Second nature, 264.

Seelye on zoöphytes, 69 .

Selection, 18.

becomes adaptation, 26 .

of sensation, 26r.

Self-activity, 89 .
Self and non-self, 259.

Senescence of protozoa, 162 .

Senility, 282.

Sensation and action, 259, 360 .

without action, 273.

Sensations, practicality of, 370 .

Sensorium, 264.

Servetus, burning of, 376 .

Sex control, I37.

determination of, $x_{3} 6$.

Sexless embryo, 136 .

Sex, meaning of, 312 .

Sexus sequior, 323 .

Shipley on brachiopods, 238.

Shore larks, 214.

Sicanites, 236.

Silva (Carmen) on prenatal influences, 134 .

Simple components in development, 103.

Slavery, 288.

Slums, degeneration in, 288.

Smith, on fossil cephalopoda, 229.

Sober mind, 358.

Somatic protoplasm, 101. tissues, 158 .

Somerville, selective breeding, 19.

Sparrow, increase of, 22.

Special creation, 10.

Species, analogy with words, 216.

and varieties, 211.

as divine ideas, 9 .

change with space, 14.

change with time, 14, 219.

definition of, 212 .

development of, 45 .

distribution of, rgr.

good and bad, Ir.

how defined, 215.

meaning of, $x$.

number of, 2.

of North American fishes, 12.

origin of, 5 .

old idea of, 44 .

reality of, $\mathbf{4 4}$.

uncertainty of definition of, Ir. 
Species, varieties of a larger growth, II.

Spencer on acquired characters, 98 , I30, 13 I.

on philosophy of evolution, 46 , 66.

on physiological units, 104, 178. on survival of the fittest, 18,84 . Spent passions transmitted, 136 .

Spermatocyte, $\mathbf{I} 7 \mathrm{I}$.

Spermatozoids, 168.

Sperm cell, 171 .

Sphærechinus granularis, 186.

Spindle, 15 r. of cell nucleus, 154 .

Spiritual pauperism, 298.

Spontaneous generation, 5, 7I, 346, 348.

Stability of truth, 334 .

Stages in development, 235.

Starbuck on adolescence, 272.

Star, origin of the word, 217.

Starvation, effect on development, II2.

Station life in Australia, 205.

"Stature from father," 27, 118.

Stead, 290.

Steinmann on ammonites, 246 .

Struggle for existence, $19,85,86$.

for existence threefold, 29,85 .

for realities, 366 .

Styrites, 247.

Subspecies, $21 x$.

Suggestion, 37 .

Superstition, growth of, $35^{8}$.

Survival of the existing, 31, 97, 146, 218.

Survival of the fittest, $18,83,84,146$, 3 or.

Systema naturæ, $\mathbf{r}$.

Tachygenesis, 232.

Tapir in North America, 200.

Taylor, translation from Goethe, 118 .

Telophases, $156,157$.

Tentaculites, 240.
Ternoceras, 253.

Test of truth, 342.

Tetrads, $180,181$.

Thalassoceras, 244.

Theologians, 50.

Theology and science, meeting point, 50.

Thistles in Australia, 204.

Thomson on larva of echinoderms, 237.

Thoreau on degeneration of villagers, 297.

on insensibility of Nature, $6 \mathbf{r}$.

on market for blood, 328 .

on passing of institutions, 298.

Thoroughbreds, $126-128$.

Three-eyed vertebrates, 34 .

Thyroid gland, disease of the, 284 .

Tirolites, 234.

Trachyceras, 234, 247.

Tradition, 367 .

Transmission of vitality, $\mathrm{x} 35$.

Tribe of Ishmael, 304.

Trifolium pratense, $2 \mathbf{2}$. repens, 21.

Trilobites, evolution of, 239.

Triviality of woman, 3 Ig.

Tropiceltites, 247.

Tropics, degeneration in the, 288.

Tropical life, 198, 227.

Tropitidæ, 244.

Trout in Yellowstone Park, 205.

Trust in realities, 360 .

Truth not absolute, 336 . stability of, 334 . test of, 342 .

the perfect, 365 .

Tunicates, 278.

Turnspit dogs, 115 .

Turrilites, 245.

Two worlds at once, 359 .

Tyndall, experiments of, $7 \mathrm{I}$.

Tyranny, evolution of, 33 r.

Ultimate truth unknown, 34 r.

Unger on cells, 152 . 
Unicellular organisms, I49.

Units of life, 177.

Unity in Nature, 346.

of type, 2.

Use and disuse, II3.

Van Beneden on centrosome, $15 \mathrm{I}$.

Variability, 104.

Varieties, 211.

Variety in life, I. produced by bisexual parentage, 27.

Vertebræ of deep-sea fishes, 222. of extinct fishes, 223 . of fresh-water fishes, 222. of northern fishes, 221 . of pelagic fishes, 222. of tropical fishes, 222.

Vestigial organs, 33 .

Virchow on derivation of cells, I52.

Virtue, 264 .

Vital force, 346 .

Vital units, 104, 177.

Volvox, 167.

"Vom Vater hab' ich die Statur," 27.

Von Buch on ammonites, 243 .

Von Mohl on cells, 152 .

Waagen on ammonites, 249.

Wakefield on animal life in New Zealand, 20r.

Waldo, lineage of, 162 .

Wallace on acquired characters, 129.

on evolution of mind, 352. on isolation, 192.

on the holarctic realm, r97.

Ward on acquired characters, 130.

Warfare of science, 368,375 .

Warner on true function of charity, 3II. on brotherly love, 96 .

Weasels, white in winter, 25.

Weeds, 201.
Weismann on adaptation, 87 .

Weismann on acquired characters, I29, 35I. on biophores, 104, 178 . on bisexual parentage, $3^{13}$. on cell division, 94. on Lamarckian factors, 116. on prenatal influences, 134 . on stable germ plasm, rog. theory of heredity, I77, 178, 376 .

Weissmann's theories, rro.

White on the struggle with dogmatic theology, 369, 375 .

Whitman (Walt) on parental environment, 133 .

on structure, the basis of life, ro4, Io6.

Whymper on cretins, $285,286$.

Wiesner on plasomes, 104, 178.

Wilberforce on developed turnips, 68 .

Will, 263 .

William the Conqueror, $14 \mathrm{I}, \mathrm{x}_{4} 2$.

Wilson on size of sperm cell, 173 .

Winter pelage white, 25 .

Wisdom, 263. sanction of, 377 .

Withered branches, 283 .

Woman, dependence of, 326 . deceit of, 319. difficulties in being one, 332 . in division of labour, 315 . emancipation of, 33 r. enmity of, 320. kindness of, 3 rg. obedience of, 326 . on manual labour, 328 . normal work of, 328 . philistinism of, 323 . secrecy of, 3 I 9. the sexus sequior, 323 . the unæsthetic sex, 32 . triviality of, $3^{18}$. not undeveloped man, $3^{15}$. Women as road-menders, 324 . Woodruff on Egyptian fatalism, 289. Words, origin of, 216. 
Working hypothesis, 255.

World as it is, 264. that is, 274 .

Worship, 373 .

Würtemberger on the law of development, 233.

Yolk of egg, 39 .

Youatt on selective breeding, 19.
Youmans on life in New Zealand, 202.

Zahme Xenien, 118.

Zangwill on the "higher foolishness," 290.

Zittel on ammonites. 246.

Zoōlogical Record, 2.

Zjgotes, 165 .

THE END. 


\section{APPLETON \& CO.'S PUBLICATIONS.}

THE SYNTHETIC PHILOSOPHY OF HER. $B E R T$ SPENCER. In ten volumes. I2mo. Cloth, \$2.00 per volume. The titles of the several volumes are as follows :

(r.) FIRST PRINCIPLES.

I. The Unknowable.

(2.) THE PRINCIPLES OF BIOLOGY. Vol.I.

I. The Data of Biology. II. The Inductions of Biology. III. The Evolution of Life.

(3.) THE PRINCIPLES OF BIOLOGY. Vol. II.

IV. Morphological Development. V. Physiological Development. VI. Laws of Multiplication.

(4.) THE PRINCIPLES OF PSYCHOLOGY. Vol. I.

I. The Data of Psychology.

II. The Inductions of Psychology. IV. Special Synthesis. V. Physical Synthesis.

(5.) THE PRINCIPLES OF PSYCHOLOGY. Vol. II.

VI. Special Analysis.

VII. General Analysis.

VIII. Congruities.

IX. Corollaries.

(6.) THE PRINCIPLES OF SOCIOLOGY. Vol. I.

I. The Data of Sociology. $\quad$ II. The Inductions of Sociology. III. The Domestic Relations.

(7.) THE PRINCIPLES OF SOCIOLOGY. Vol. II.

IV. Ceremonial Institutions. $\quad \dot{V}$. Political Institutions.

(8.) THE PRINCIPLES OF SOCIOLOGY. Vol. III.

VI. Ecclesiastical Institutions. VII. Professional Institutions. VIII. Industrial Institutions.

(9.) THE PRINCIPLES OF ETHICS. Vol. I.

1. The Data of Ethics.

III. The Ethics of Individual Life.

(ro.) THE PRINCIPLES OF ETHICS. Vol. II.

IV. The Ethics of Social Life: Justice.

V. The Ethics of Social Life: Negative Beneficence.

VI. The Ethics of Social Life: Positive Beneficence.

DESCRIPTIVE SOCTOLOGY. A Cyclopadia of Social Facts. Representing the Constitution of Every Type and Grade of Human Society, Past and Present, Stationary and Progressive. By Herbert Spencer. Eight Nos., Royal Folio.

No. I. ENGLISH . . . . . . . . . . . . . . $\$ 4 \infty$

No. II. MEXICANS, CENTRAL AMERICANS, CHIBCHAS, and PERUVIANS

No. III. LOWEST RACES, NEGRITO RACES, and MALAYO-POLY. NESIAN RACES ............. 400

No. IV. AFRICAN RACES. . . . . . . . . . . . . . . $4+$

No. V. ASIATIC RACES . . . . . . . . . . . . . $4 \infty$

No. VI. AMERICAN RACES . . . . . . . . . . . 40

No. VII. HERREWS and PHCENICIANS. . . . . . . . . . . 40

No. VIII. FRENCH (Double Number) . . . . . . . . . . . . $7 \infty$ 


\section{APPLETON \& CO.'S PUBLICATIONS.}

NEW EDITION OF PROF. HUXLEY'S ESSAYS.

COLLECTED ESSAYS. By Thomas H. Huxley. New complete edition, with revisions, the Essays being grouped according to general subject. In nine volumes, a new Introduction accompanying each volume. I2mo. Cloth, $\$ 25$ per volume.

\section{VoL. I.-METHOD AND RESULTS. \\ VOL. II.-DARWINIANA. \\ VOL. III.-SCIENCE AND EDUCATION. \\ VOL. IV.-SCIENCE AND HEBREW TRADITION. \\ VOL. V.-SCIENCE AND CHRISTIAN TRADITION. \\ VoL. VI.-HUME. \\ VOL. VII.-MAN'S PLACE IN NATURE. \\ VOL. VIII.-DISCOURSES, BIOLOGICAL AND GEOLOGICAL. VOL. IX.-EVOLUTION AND ETHICS, AND OTHER ESSAYS.}

"Mr. Huxley has covered a vast variety of topics during the last quarter of a century. It gives one an agreeable surprise to look cver the tables of contents and note the inmense territory which he has explored. To read these books carefully and studiously is to become thoroughly acquainted with the most advanced thought on a large number of topics." - New York Herald.

"The series will be a welcome one. There are few writings on the more abstruse problems of science better adapted to reading by the general public, and in this form the books will be well in the reach of the investigator. . . . The revisions are the last expected to be made by the author, and his introductions are none of earlier date than a few months ago [1893], so they may be considered his final and most authoritative utterances."-Chicago Times.

"It was inevitable that his essays should be called for in a completed form, and they will be a source of delight and profit to all who read them. He has always commanded a hearing, and as a master of the literary style in writing scientific essays he is worthy of a place among the great English essayists of the day. This edition of his essays will be widely read, and gives his scientific work a permanent form."-Boston Herald.

"A man whose brilliancy is so constant as that of Prof. Huxley will always command readers; and the utterances which are here collected are not the least in weight and luminous beauty of those with which the author has long delighted the reading world."-Philadelphia Press.

"The connected arrangement of the essays which their reissue permits brings into fuller relief Mr. Huxley's masterly powers of exposition. Sweeping the subject-matter iclear of all logomachies, he l-ts the light of common day fall upon it. He shows that the place of hypothesis in science, as the starting point of verification of the phenomena to be explained, is but an extension of the assumptions which underlie actions in everyday affairs; and that the method of scientific investigation is only the method which rules the ordinary business of life."-London Chronicle.

New York: D. APPLETON \& CO., 72 Fifth Avenue. 


\section{APPLETON AND COMPANY'S PUBLICATIONS.}

\section{PIONEERS OF EVOLUTION, from Thales to Huxley. By Edward Clodd, President of the Folk-Lore Society ; Author of "The Story of Creation," "The Story of 'Primitive' Man," etc. With Portraits. 12mo. Cloth, \$1.50.}

"The mass of interesting material which Mr. Clodd has got together and woven into a symmetrical story of the progress from ignorance and theory to knowledge and the intelligent recording of fact is prodigious. . . . The 'goal' to which Mr. Clodd leads us in so masterly a fashion is but the starting point of fresh achievements, and, in due course, fresh theories. His book furnishes an important contribution to a liberal education."-London Daily Chronicle.

"We are always glad to meet Mr. Clodd. He is never dull; he is always well informed, and he says what he has to say with clearness and precision. ... The interest intensifies as Mr. Clodd attempts to show the part really played in the growth of the doctrine of evolution by men like Wallace, Darwin, Huxley, and Spencer. . . . We commend the book to those who want to know what evolution really means."-London Times.

"This is a book which was needed. . . . Altogether, the book could hardly be better done. It is luminous, lucid, orderly, and temperate. Above all, it is entirely free from personal partisanship. Each chief actor is sympathetically treated, and friendship is seldom or never allowed to overweight sound judgment."-London Acadcmy.

"We can assure the reader that he will find in this work a very useful guide to the lives and labors of leading evolutionists of the past and present. Especially serviceable is the account of Mr. Herbert Spencer and his share in rediscovering evolution, and illustrating its relations to the whole field of human knowledge. His forcible style and wealth of metaphor make all that Mr. Clodd writes arrestive and interesting."-London Literary World.

" Can not but prove welcome to fair-minded men. . . . To read it is to have an object-lesson in the meaning of evolution. . . . There is no better book on the subject for the general reader. . . . No one could go through the book without being both refreshed and newly instructed by its masterly survey of the growth of the most powerful idea of modern times."-Ths Scotsman.

\section{APPLETON AND COMPANY, NEW YORK.}




\section{APPLETON \& CO.'S PUBLICATIONS.}

\section{DIONEERS OF SCIENCE IN AMERICA. \\ Sketches of their Lives and Scientific Work. Edited and re. vised by William JaY Youmans, M.D. With Portraits. 8vo. Cloth, \$4.00.}

Impelled solely by an enthusiastic love of Nature, and neither asking nor receiving outside aid, these early workers opened the way and initiated the movement through which American science has reached its present commanding position. This book gives some account of these men, their early struggles, their scientific labors, and, whenever possible, something of their personal characteristics. This information, often very difficult to obtain, has been collected from a great variety of sources, with the utmost care to secure accuracy. It is presented in a series of sketches, some fifty in all, each with a single exception accompanied with a well-authenticated portrait.

"Fills a place that needed filling, and is likely to be widely read." $-N$. Y. Sux.

"It is certainly a useful and convenient volume, and readable too, if we judge correctly of the degree of accuracy of the whole by critical examination of those cases in which our own knowledge enables us to form an opinion. . . . In general, it seems to us that the handy volume is specially to be commended for setting in just bistorical perspective many of the earlier scientists who are neither very generally nor very well known."-New York Evening Post.

"A wonderfully interesting volume. Many a young man will find it fascinating. The compilation of the book is a work well done, well worth the doing."-Philadelpha Press.

"One of the most valuable books which we have received."-Boston Advertiser.

"A book of no little educational value. . . . An extremely valuable work of reference."-Boston Beacon.

"A valuable handbook for those whose work runs on these same lines, and is likely to prove of lasting interest to those for whom 'Les documents humair' ' are second unly to history in importance-nay, are a vital part of history." - Boston Transcript.

"A biographical history of science in America, noteworthy for its completeness and scope. . . All of the sketches are excellently prepared and unusually interesting." Chicago Record.

"One of the most valuable contributions to American literature recently made. . . The pleasing style in which these sketches are written, the plans taken to secure ac. curacy, and the information conveyed, combine to give them great value and interest. No hetter or more inspiring reading cruld be placed in the hands of an intelligent and aspiring young man." -New York Christian Work.

"A book whose interest and value are not for to-day or to-morrow, but for indefinite time."-Rochester Herald.

"It is difficult to imagine a reader of ordinary intelligence who would not be entertained by the book. . . . Conciseness, exactness, urbanity of tone, and interestingness are the four qualities which cliefly impress the rearler of these sketches."-Buffalo Express.

"Full of interesting and valuable matter."-The Churchman.

New York: D. APPLETON \& CO, 72 Fifth Avenue. 


\section{APPLETON AND COMPANY'S PUBLICATIONS.}

THE ANTHROPOLOGICAL SERIES.

NOW READY.

HE BEGINNINGS OF ART. By ERNST
Grosse, Professor of Philosophy in the University of Freiburg. A new volume in the Anthropological Series, edited by Pro. fessor Frederick Starr. Illustrated. I2mo. Cloth, \$1.75.

"This book can not fail to interest students of every branch of art, while the gensral reader who will dare to take hold of it will have his mind broadened and enriched beyond what he would conceive a work of many times its dimensions might effect." Brooklyn Eagle.

"The volume is clearly written, and should prove a popular exposition of a deeply interesting theme." - Fhiladelphia Public Ledger.

\section{TOMAN'S SHARE IN PRIMITIVE CUL- TURE. By Otis Tufton Mason, A. M., Curator of the Department of Ethnology in the United States National Mu- seum. With numerous Illustrations. 12mo. Cloth, \$1.75.}

"A most interesting $r / s u m \ell$ of the revelations which science has made concerning the habits of human beings in primitive times, and especially as to the place, the duties, and the customs of women."-Philadelphia Inquirer.

\section{THE PYGMIES. By A. DE Quatrefages, late} Professor of Anthropology at the Museum of Natural History, Paris. With numerous Illustrations. I2mo. Cloth, \$1.75.

"Probably no one was better equipped to illustrate the general subject than Quatrefages. While constantly occupied upon the anatomical and osseous phases of his subject, he was none the less well acquainted with what literature and history had to say concerning the pygmies. . This book ought to be in every divinity school in which man as well as God is studied, and from which missionaries go out to convert the human being of reality and not the man of rhetoric and text-books." - Boston Literary World.

\section{THE BEGINNINGS OF WRITING. By W. J. Hoffman, M. D. With numerous Illustrations. 12mo. Cloth, $\$ 1.75$.}

"The author, as one of the foremost of our ethnologists, is well qualified for the inquiry, and the result of his labors is not only a monument to his industry, but a most valuable contribution to our national history as well. It is a book full of interest even to the general reader, while to the scientist it is a nich mine of facts."-Chicago Evening Post.

IN PREPARATION.

THE SOUTH SEA ISLANDERS. By Dr. SCHMELTZ.

THE ZUÑ. By Frank hamilton Cushing.

THE AZTECS. By Mrs. Zelia Nuttall.

\section{APPLETON AND COMPANY, NEW YORK.}




\section{APPLETONS' \\ POPULAR SCIENCE MONTHLY.}

EDITED BY WILLIAM JAY YOUMANS.

$\$ 5.00$ per annum; single copy, 50 cents.

Appletons' Popular Science Monthly is always prompt to present the expert treatment of important topics of the day, which are within the wide range of its interest. It deals particularly with those general and practical subjects which are of the greatest interest and importance to the people at large. All its articles are by writers of long practical acquaintance with their subjects, and are written in such a manner as to be readily understood.

In the last few months the magazine has offered Mr. MCPherson's lucid discussions of the Monetary and Banking Problem, and the studies of "The Social Functions of Wealth," by M. Paul Leroy Beaulieu. To these articles, and to the series by the Hon. David A. Wells upon "The Principles of Taxation," not yet completed, it is possible now to add the announcement of a most important and timely study of "The Present Financial Problem," by Mr. Wells, which will begin probably in the September number.

\section{APPLETON \& CO., Publishers,}

72 FIFTH AVENUE, NEW YORK. 



THE LIBRARY

UNIVERSITY OF CALIFORNIA

Santa Barbara

THIS BOOK IS DUE ON THE LAST DATE STAMPED BELOW.

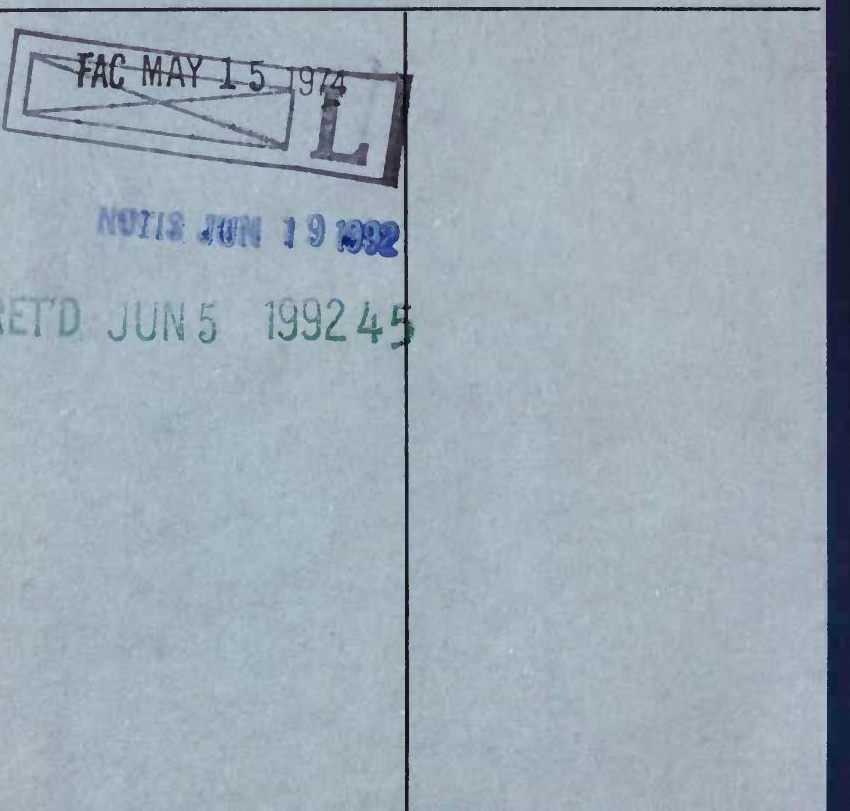


